MARIANA CONTI CRAVEIRO

\title{
PACTOS PARASSOCIAIS PATRIMONIAIS: \\ ELEMENTOS PARA SUA INTERPRETAÇÃO NO \\ DIREITO SOCIETÁRIO BRASILEIRO
}

\author{
Tese de Doutorado em Direito Comercial \\ Orientadora: Professora Titular Paula A. Forgioni \\ Faculdade de Direito da Universidade de São Paulo \\ São Paulo \\ 2012
}




\title{
PACTOS PARASSOCIAIS PATRIMONIAIS: ELEMENTOS PARA SUA INTERPRETAÇÃO NO DIREITO SOCIETÁRIO BRASILEIRO
}

\author{
Tese apresentada como requisito parcial \\ de obtenção do grau de Doutor em Direito \\ Comercial pelo Programa de Pós- \\ Graduação da Faculdade de Direito da \\ Universidade de São Paulo, sob a \\ orientação da Professora Titular Dra. \\ Paula A. Forgioni.
}

Faculdade de Direito da Universidade de São Paulo

São Paulo

2012 
Aos meus pais,

Luis Alberto e Magda 


\section{AGRADECIMENTOS}

A jocosa afirmação de que redigir uma tese acadêmica é um calvário ganha sentido completo apenas após trilhado o caminho. A travessia, de fato, não depende apenas do esforço e bom ânimo do pesquisador, mas muito da colaboração e compreensão de quem, direta ou indiretamente, em maior ou menor grau, auxilia-o a enfrentar as escarpas.

Em primeiro lugar, agradeço à minha orientadora, Profa. Paula Andrea Forgioni, e à Universidade de São Paulo pela oportunidade de, uma vez mais, regressar à velha e sempre nova academia para cumprir o ciclo da minha formação, sendo despiciendo anotar meu orgulho em cumprir todas as suas etapas na Faculdade de Direito do Largo de São Francisco, esperançosa de que o trabalho que ora se conclui esteja à altura dessa responsabilidade. À Profa. Paula, em específico, minha gratidão por tudo o que me ensinou durante mais de doze anos de convivência acadêmica e profissional. Sua conhecida exigência por qualidade cativou-me desde o nosso primeiro encontro e sintome honrada pela confiança que, desde aquele dia de 1999, depositou em mim e no meu potencial, estimulando-me a buscar a realização de meus propósitos.

Ao Professor José Alexandre Tavares Guerreiro pela generosidade em confiar-me a utilização de sua rica biblioteca e em muito discutir comigo o tema escolhido, encorajando-me a enfrentá-1o. Ao Professor Francisco Satiro de Souza Jr., pelas sugestões e críticas que me permitiram melhor dimensionar o trabalho. Ao Professor Gustavo Saad Diniz, da Faculdade de Direito da USP de Ribeirão Preto, pelo constante intercâmbio de ideias.

Ao Max-Planck-Institut für ausländisches und internationales Privatrecht, nas pessoas do Prof. Klaus Hopt e Dr. Jan Peter Schmidt, pela bolsa de estudos concedida durante o ano de 2010 e pela singular oportunidade de, em Hamburgo, encontrar as condições ideais para estruturar esta tese. Aos colegas de instituto, nas pessoas de Elena de Carvalho Gomes, Catarina Monteiro Pires, Mariana Fontes da Costa, Margarida Almeida, Victor Hugo Chacon e Gabriel Saad Kik Buschinelli que me brindaram, durante a 
estada Alemanha e o período de redação da tese, com profundas discussões e envio de material, na mais pura essência da colaboração acadêmica.

Aos colegas de pós-graduação, Marcel Edvar Simões, Ligia Paula Pires Pinto Sica e Carla Tomazella, pelo debate de ideias e pela segurança de poder contar com suas críticas. A Rodrigo Carneiro Cipriano, pelo inestimável auxílio na pesquisa e colheita do material, bem como nas discussões e revisões iniciais do texto. Igualmente, a Marilia Ferreira de Miranda e aos acadêmicos de direito Ana Carolina Folgosi Bittar, Bruna Hayar Fuscella, Pedro Bini Ferreira, Paulo Henrique Pinto e Ana Luisa Taborda Sanches, pela reunião de textos e revisão de bibliografia.

Ao meu "capo", Fabio Buccioli, por me permitir, ao longo de tantos anos, a quotidiana vivência dos temas que perfazem o objeto desta tese. Aos colegas de escritório Guilherme José Braz de Oliveira, Verônica Vargas da Rosa e Thiago Munhoz Agostinho, pela compreensão ao substituirem-me em tantas ausências. A Cristiane Ferreira Fidêncio e Ricardo Borges de Lima, pelo suporte constante e eficiente, fundamental na árdua compatibilização entre o rigor da vida acadêmica e a frenética atividade na advocacia, pelo que também agradeço às diligentes Rosana Hashimoto e Cacilda de Oliveira.

A todas as minhas amigas-irmãs, nas pessoas de Lia Mitsue Ota Zanchet, Marina Garcia Marini Stamato e Maria Lucia Lacerda Coelho de Paula Lopes, pelo suporte ao meu esforço e constante torcida para que tudo chegasse a bom fim, no que agradeço também a Ulrike Warneke, Beatrix Andraus e Eliana Kaneshiro.

E, sobretudo, agradeço aos meus pais Luis Alberto e Magda, a quem dedico este trabalho, pelo incansável encorajamento e por tudo o que empreenderam para que eu estivesse aqui, hoje; ao meu marido, Godofredo Carbinatto Júnior, pela paciência e renúncia ao proveito de momentos felizes, em prol deste trabalho; a toda minha família, enfim, pela força e serenidade que me proporcionam, sem o quê nada pode ser realizado. 


\section{RESUMO}

O fenômeno da contratualização do direito societário tem se intensificado nos diversos ordenamentos, sobretudo com relação a sociedades anônimas fechadas - constituidas no âmbito de joint ventures e aquelas que recebem investimentos de private equity. Nesse cenário, os acordos celebrados entre acionistas para reger seu relacionamento societário de maneira complementar e paralela aos atos constitutivos das sociedades (amplamente designados "shareholders' agreements") são traços característicos. Designados em 1942 por Giongio OPPo como Contratti Parasociali, sua análise doutrinária, em geral, tem se focado no exame de sua relação com o contrato ou estatuto social, ocupando-se principalmente dos acordos incidentes sobre a organização e funcionamento da companhia (notadamente os acordos de voto) e seus efeitos societários. Com relação aos pactos relativos a direitos patrimoniais dos celebrantes, o fato de não produzirem efeitos diretos sobre a companhia reduz seu exame sob a ótica do direito societário. A tese tem como objetivo primário, assim, caracterizar esse grupo de contratos assinalando como sua função econômica a de modelar o relacionamento societário entre as partes. Verifica-se, pois, que as disposições do pactos em exame não apenas geram vínculos obrigacionais entre os signatários, mas também gravam o status de sócio de cada um deles. No Brasil, o estudo dos pactos parassociais é centrado no exame dos acordos de acionistas previstos no art. 118 da Lei $6.404 / 76$, não tendo sido identificadas obras que avaliem os pactos parassociais como gênero de que o acordo de acionistas é espécie. Pouco se explora, sob a perspectiva societária, ajustes com conteúdo patrimonial ou mesmo aspectos gerais dos pactos parassociais, como sua interpretação e limites de validade. O escopo principal da tese seria, então, o de examinar como as peculiares circunstâncias em que se inserem os pactos parassociais patrimoniais influenciam seu processo de interpretação e propor elementos para que considerações derivadas da lógica societária orientem o intérprete, buscando superar argumentos de concepção individualista, ligados a defesa de ampla liberdade contratual das partes na celebração de ajustes relativos a seus direitos patrimonais. Com esse propósito, analisa-se regras consagradas de hermenêutica - notadamente as relativas à necessidade de exame da função econômica do contrato e da boa-fé objetiva - e elementos de sustentação da lógica societária, como o escopo comum, os deveres e direitos dos sócios. Além disso, verifica-se os principais elementos apontados na doutrina como limitadores da autonomia contratual no direito societário e, por fim, reflete-se sobre a relação dos pactos parassociais patrimoniais com os alvos de tutela do direito societário. 
Palavras chave: - pactos parassociais - acordo de acionistas - joint ventures - private equity - direitos patrimoniais - status socii - boa-fé objetiva - dever de lealdade - interpretação. 


\begin{abstract}
The phenomenon of contracts in corporate law has intensified in the various legal systems, particularly with respect to closely held corporations incorporated as joint ventures and those that receive private equity investments. In this scenario, the agreements executed between shareholders governing their relationship in a complementary and parallel manner to the company bylaws (widely known as "shareholders' agreements") are characteristic features. Designated in 1942 by Giorgio Oppo as Contratti Parasociali, its doctrinal analysis, in general, focuses on the examination of the relationship with the contract or bylaws of the company, dealing primarily with agreements regarding organization and operation of the company (notably the voting agreements) and the corporate effects arising therefrom. With respect to agreements concerning patrimonial rights of the parties, the fact that they do not produce direct effects on the company reduces its analysis from the perspective of corporate law. The initial purpose of the thesis, thus, is to characterize this group of contracts indicating that their economic purpose is to model the corporate relationship between the parties. The provisions of the agreements in question not only create obligation ties between the parties but also mark their partner status. In Brazil, the analysis of shareholders' agreements is centered in "acordos de acionistas" provided for in art. 118 of Law 6404/76, and no studies were found regarding shareholders' agreements as a class of which acordo de acionistas is a type. Agreements with patrimonial contents or even general aspects of shareholders' agreements, such as their interpretation and validity limits, are poorly studied. The main purpose of the thesis thus, is to examine how the peculiar circumstances in which the patrimonial shareholders' agreements are inserted may impact their interpretation process and to propose elements so that aspects arising from the specific corporate logic may orient the interpreter, aiming at overcoming individualistic arguments, linked to the defense of broad freedom of contract by the parties in the adjustments concerning their patrimonial rights. The recognized rules of hermeneutics are analyzed especially those relating to the need to examine the economic function of the contract and the objective good faith - and the supporting elements of corporate logic, as the ordinary scope, duties and rights of the partners. In addition, the main elements pointed out in the doctrine as limiting of the contractual autonomy in corporate law are verified and the relationship of shareholders' agreements with the targets of protection of corporate law is analyzed.
\end{abstract}

Keywords: - Shareholders' agreements - joint ventures - private equity patrimonial rights - status socii - objective good faith - fiduciary duties interpretation. 


\section{RIASSUNTO}

Il fenomeno della contrattualizzazione del diritto societario viene sempre più intensificandosi nei diversi ordinamenti, soprattutto con riferimento alle società anonime chiuse - quelle costituite nell'ambito di operazioni di joint ventures e quelle che ricevono investimenti di private equity. In questo scenario, i patti celebrati tra gli azionisti per regolare il loro rapporto societario in maniera complementare e parallela agli atti costitutivi della società (a cui genericamente ci si riferisce col nome di "shareholders' agreements") costituiscono tratti caratteristici di tale fenomeno. Denominati nel 1942 da Giongio OpPo Contratti Parasociali, la loro analisi dottrinaria, in generale, si è incentrata sul rapporto che intercorre tra gli stessi e il contratto o lo statuto societario, approfondendo in particolar modo i patti incidenti sull'organizzazione e il funzionamento della società (specialmente gli accordi per il voto) e i loro effetti societari. Con riferimento ai patti riguardanti i diritti patrimoniali dei soci, il fatto di non produrre effetti diretti sulla società ne ha limitato l'esame sotto l'ottica del diritto societario. La tesi ha come obiettivo iniziale, dunque, quello di caratterizzare questo gruppo di contratti, mettendone in luce come la loro funzione economica sia quella di modellare il rapporto societario tra le parti. Si dimostra, poi, come le disposizioni dei patti in esame non solo generano vincoli obbligazionari tra i firmatari, ma informano anche lo status di socio di ognuno di questi. In Brasile, lo studio dei patti parasociali è incentrato sull'esame degli "acordos de acionistas" previsti nell'art. 118 della Legge 6.404/76, e non sono state trovate opere che considerano i patti parasociali alla stregua di un genere di cui l'acordo de acionistas è una specie. Si indagano poco, sotto la prospettiva societaria, i patti con contenuto patrimoniale egli aspetti generali dei patti parasociali, come la loro interpretazione e i limiti di validità. Lo scopo principale della tesi sarebbe, allora, quello di esaminare come le circostanze peculiari in cui si inseriscono i patti parasociali patrimoniali influiscono sul loro processo di interpretazione e proporre degli elementi affinché considerazioni derivate dalla logica societaria orientino l'interprete, al fine di superare argomenti di concezione individualistica legati alla difesa dell'ampia libertà contrattuale delle parti nell'esecuzione di contratti relativi ai loro diritti patrimoniali. Con questo proposito, vengono analizzate regole consacrate di ermeneutica specialmente quelle relative alla necessità di esaminare la funzione economica del contratto e quella della buona-fede oggettiva - e gli elementi su cui si fonda la logica societaria, come lo scopo comume, i doveri e diritti dei soci. Si passano al vaglio, , inoltre, i principali elementi che la dottrina individua come limiti all'autonomia contrattuale nel diritto societario e, infine, si procede ad una riflessione sul rapporto dei patti parasociali patrimoniali con gli obiettivi di tutela del diritto societario.

Parole-chiave: - patti parasociali - accordo tra azionisti - joint ventures private equity - diritti patrimoniali - status socii- buona fede obbiettiva dovere di lealtà - interpretazione 


\section{LISTA DE ABREVIATURAS}

AASP

AA.VV.

AgRg

AktG

AI

Art.

Apel.

Bull. Joly

$\mathrm{CC}$

$\mathrm{CDC}$

$\mathrm{CF}$

Cf.

cit.

Coord.

Coords.

CPC

Des.

D.j.e

D.O.U

Ed.

Edcl

EI

FDUSP

i.e

j.

LGDJ

LS A

MC

Min.

$\mathrm{n}$.

$\mathrm{n}^{\mathrm{o}}$

obs.

Org.

Orgs.

p.

Par. ou $\S$

pp.

pt.

RDM

REsp

Riv. Dir. Comm.
Associação dos Advogados de São Paulo

Autores Vários

Agravo Regimental

Aktiengesetz (Lei Acionária Alemã)

Agravo de Instrumento

Artigo

Apelação

Bulletin Joly (periódico francês)

Código Civil

Código de Defesa do Consumidor

Constituição Federal

Conforme; Confira-se

Já citado anteriormente

Coordenador; coordenação

Coordenadores

Código de Processo Civil

Desembargador

Diário de Justiça do Eletrônico

Diário Oficial da União

Edição

Embargos de Declaração

Embargos Infringentes

Faculdade de Direito da Universidade de São Paulo Largo São Francisco

isto é

julgado em

Librerie Générale de Droit et Jurisprudence

Lei de Sociedades por Ações (Lei n. ${ }^{\circ}$ 6.404/76)

Medida Cautelar

Ministro

Nota

Número

Observação

Organizador; organização

Organizadores

Página

Parágrafo

Páginas

Parte

Revista de Direito Mercantil - Industrial, Econômico e

Financeiro

Recurso Especial

Rivista di diritto commerciale e del diritto generale delle obligazioni 
$\mathrm{RO}$

RT

RTDCom

S.A.

s/d

ss.

STF

STJ

TJRJ

TJSP

UTET

vol.
Recurso Ordinário

Revista dos Tribunais

Revue trimestrielle de droit commercial et de droit ecónomique

Sociedade Anônima

Sem data

Seguintes

Supremo Tribunal Federal

Superior Tribunal de Justiça

Tribunal de Justiça do Estado do Rio de Janeiro

Tribunal de Justiça do Estado de São Paulo

Unione Tipografico-Editrice Torinese

Volume 


\section{REGRAS DE CITAÇÃO}

Nas notas de rodapé ao longo do texto, quando se cita a obra pela primeira vez, procura-se fazer a referência completa, indicando o nome e sobrenome do autor em ordem direta, em CAIXA Alta, o título da obra em itálico, volume ou tomo, edição, cidade, editora, ano e página.

Em caso de citação de capítulo ou parte de obra, adota-se as seguintes diretrizes de identificação da fonte.

Se a obra é de vários autores, insere-se o nome e sobrenome do autor da parte citada, em ordem direta, em CAIXA ALTA, título da parte em itálico, a expressão latina “in”, nome do(s) coordenador(es) em ordem direta seguida da designação (coord.) ou (org.), título da obra em itálico, volume ou tomo, edição, cidade, editora, ano e página. Também poderá ser utilizada a expressão AAVV, em substituição enfatizando-se que se trata de obra coletiva. Se o autor da parte é também o organizador, insere-se o nome e o sobrenome do autor em ordem direta, em CAIXA ALTA, título da parte em itálico, a expressão latina "in", título da obra em itálico, volume ou tomo, edição, cidade, editora, ano e página.

Para artigos e textos de periódicos, cita-se o nome e sobrenome do autor em ordem direta, em CAIXA AlTA, título da obra em itálico, a expressão latina "in" seguida do título da revista, volume ou número, ano/mês, página.

A partir da segunda referência do mesmo autor e da mesma obra, cita-se o nome completo do autor ou seu sobrenome mais usado, em CAIXA ALTA, início do nome da obra em itálico seguido de reticências, a expressão cit. e o número da página. Em caso de autores com mais de uma obra, cita-se o nome e o sobrenome do autor, em ordem direta, em CAIXA AltA, início do nome da obra em itálico seguido de reticências, a expressão cit. e o número da página. Para duas referências seguidas do mesmo autor usa-se idem e a página. Se a página coincidir, cita-se como idem, ibidem.

$\mathrm{Na}$ seção Referências Bibliográficas indica-se, em ordem alfabética o sobrenome do autor (pelo qual é mais conhecido) em letra MAIÚSCULA, prenome, nome da obra em itálico, e demais informações, seguindo o critério adotado para as notas de rodapé.

Para citar julgados, refere-se o nome do tribunal abreviado e MAIÚSCULO, o tipo do julgado abreviado, o número da turma ou câmara, o nome do relator e a data do julgamento ou publicação em órgãos oficiais.

As citações foram mantidas em língua estrangeira, quando seu conteúdo pode ser depreendido do texto em português em que se faz a citação. Nas citações em que se traduziu para o português, manteve-se também a versão original. Em ambos os casos, procura-se, com isso, minimizar eventuais erros de compreensão derivados da tradução realizada para o vernáculo. 


\section{ÍNDICE}

ÍNDICE

ERRO！INDICADOR NÃO DEFINIDO.

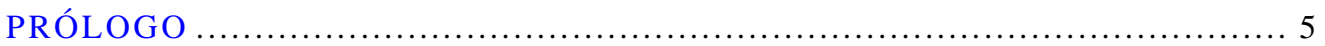

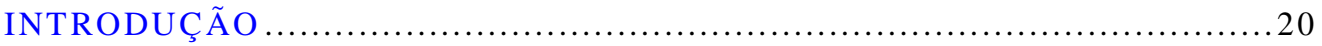

1. Contratualização do direito societário .............................24

2.Contratos parassociais: função e noção ............................. 27

3. Oppo como ponto de partida ................................... 32

4. A posição de GUYON e sua importância para a tese................ 39

5. Posição da doutrina brasileira ..................................... 41

5.1 Proposta teórica de Calixto Salomão Filho ..................................42

6. Contratos parassociais patrimoniais: precisão terminológica ...44

7. Inovação de perspectiva ....................................... 48

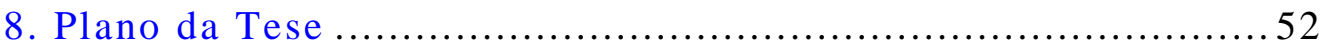

1 - HISTÓRICO DA CONTRATAÇÃO PARASSOCIAL ...........................5

1.1 - Ponderações iniciais: disciplina societária centrada no contrato de sociedade e na caracterização dos tipos societários..............53

1.2 - Evolução no direito brasileiro .................................56

1.2.1 - O Código Comercial Brasileiro de 1850 ....................................56

1.2.2 - Final do século XIX e começo do XX: leis acionárias brasileiras e a proliferação dos sindicatos de voto .........................................57

1.2.3 - Os contratos parassociais sob a disciplina societária do Decreto-Lei $n$. $2627 / 40$ .58

1.2.4 - Lei n. 6.404/76: edificação de novo sistema de direito societário brasileiro.

60

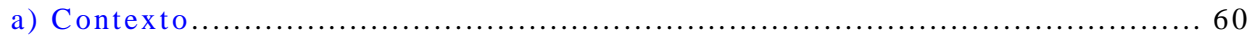

b) Posição de vanguarda: previsão legal de acordos de acionistas no art. 118 da Lei $6.404 / 76$ 62

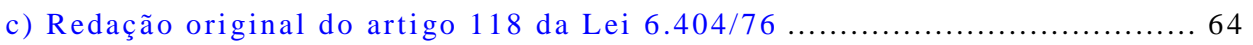

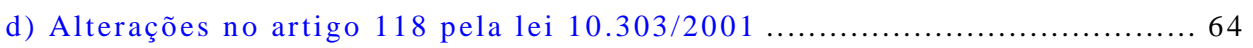

1.2.5 - Pactos parassociais e disciplina do Código Civil 2002 .................66 66

1.3 - Notas de comparação legislativa ...............................68

1.3.1 - Breve notícia das legislações da Europa Continental..................69 
1.3.2 - Peculiaridades do direito da common law...

1.4 - Conclusão e reflexões sobre o panorama atual

2 - CARACTERIZAÇÃO DOS PACTOS PARASSOCIAIS PATRIMONIAIS: FUNÇÃO ECONÔMICA

2.1 - Pactos parassociais patrimoniais: função econômica..........78

2.1.1 - Variedade de pactos e função econômica específica......................81

2.2 - Pactos relativos à compra e venda de participação societária aspectos gerais 83

2.2.1 - Opções de compra e de venda de ações..................................87

2.2 .2 - Acordos de venda conjunta.......................................90

a) Direito de venda conjunta - tag along right .............................. 90

b) obrigação de venda conjunta - drag along right ......................... 91

2.3 - Acordos restritivos da circulação de ações.....................93

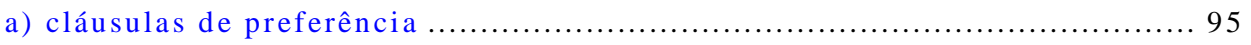

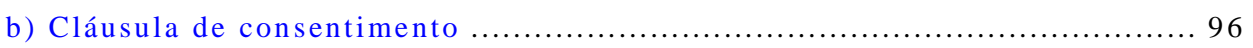

c) Cláusulas de permanência ("lock in" ou "lock up") ............................ 98

2.4 - Pactos ligados a outros direitos patrimoniais dos sócios ....99

2.4 .1 - Acordos de não concorrência ...................................... 100

2.4 .2 - Acordos prevendo outras prestações acessórias dos sócios.......... 102

a) financiamento, capitalização e distribuição de resultados da sociedade ....105

b) transferência de tecnologia e cessão em uso de direitos de propriedade

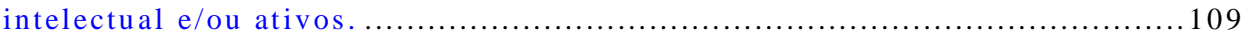

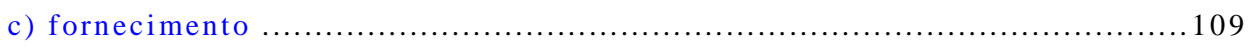

2.5 - Conclusão ..................................................... 110

3 - DISCIPLINA JURÍDICA DOS PACTOS PARASSOCIAIS PATRIMONIAIS NO

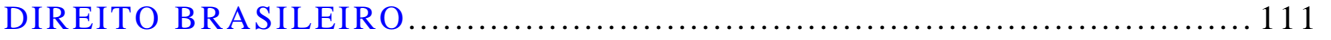

3.1 - Disciplina legal: introdução .............................. 111

3.2 - Oponibilidade e acordos de acionistas ..................... 114

3.2.1- Relatividade de contratos e acordos de acionistas...................115

3.3 - Oponibilidade e pactos parassociais com outros conteúdos patrimoniais ....................................................... 120

3.4 - Produção de efeitos reflexos................................ 125

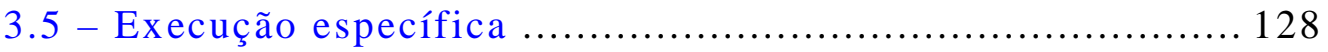


3.6 - Pactos parassociais patrimoniais e outras categorias contratuais. 132

3.6.1 - Contrato plurilateral com comunhão de escopo. Contratos de longa duração, relacionais, incompletos ou de colaboração. 133

3.6.2 - Contratos incompletos 136

3.6.3- Contratos-quadro.... 137

3.6.4 - Contratos normativos 138

3.7 - Conclusões. Proposta de definição de pactos parassociais patrimoniais e utilidade do subgrupo proposto. 139

4. - ELEMENTOS PARA INTERPRETAÇÃO DOS PACTOS PARASSOCIAIS PATRIMONIAIS NO DIREITO SOCIETÁRIO BRASILEIRO.

4.1 - Pressuposto essencial ao exame da interpretação: pactos parassociais e sua intrínseca ligação com a relação societária... 142 4.2 - Segundo pressuposto: real alcance da teoria geral dos contratos nos pactos parassociais patrimoniais

4.3 - O papel da interpretação para os pactos parassociais patrimoniais. 149

4.4 - Elementos da tradicional teoria da interpretação dos negócios jurídicos 154

4.4 .1 - Interpretação conforme a intenção comum das partes: função econômica do contrato. Contexto negocial e espírito do contrato. 155 4.4 .2 - Boa fé e tutela da confiança nas relações entre sócios. Estado de sócio e expectativas legítimas 159

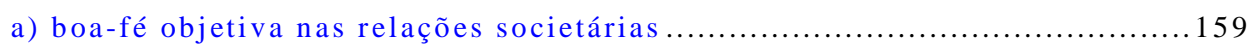

b) Affectio societatis, confiança e expectativas legítimas.... 162

4.5 - Elementos de interpretação baseados em alguns princípios de sustentação à lógica societária 164

4.5.1 - Escopo comum: a base da noção de sociedade. 165

4.5.2 - Deveres dos sócios.... 167

a) Deveres de sócio no direito positivo brasileiro 172

4.5.3 - Escopo comum e deveres dos sócios como elementos para a interpretação de pactos parassociais patrimoniais.... 173

4.5.4 - Vedação ao pacto leonino 176

a) Legislação brasileira . 179 
b) Pactos leoninos na prática societária

c) Vedação ao pacto leonino e interpretação dos pactos parassociais patrimoniais.

4.5.5 - Direitos de sócio

a) direito a não restar prisioneiro da sociedade: circulação de ações e direito de retirada 185

b) direito a permanecer associado ........................................ 190

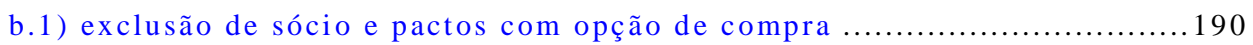

b.2) resgate de ações ...................................................... 195

c) direito a não ter sua participação diluída injustificadamente ................. 198

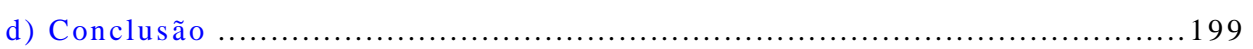

4.6 - Outros elementos apontados na doutrina....................... 200

4.6.1. Introdução: Pactos parassociais patrimoniais e a discussão sobre autonomia contratual no direito societário. .............................. 200

4.6 .2 - O respeito ao tipo societário .................................... 201

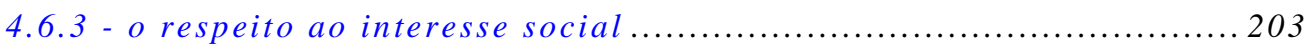

4.6.4 - O respeito à ordem pública societária.............................. 205

4.7 - Interpretação dos pactos parassociais patrimoniais e alvos de tutela do direito societário ................................... 210

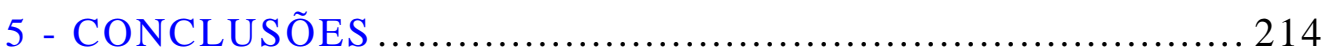




\section{PRÓLOGO}

\section{Relatório de pesquisa (2008-2010)}

1. A presente tese (Pactos parassociais patrimoniais. Elementos para sua interpretação no direito societário brasileiro ${ }^{1}$ ) representa a fase final de pesquisas ligadas ao tema da autonomia contratual no direito societário que vimos desenvolvendo desde o ano de 2008, quando o projeto original de doutoramento (Fundamentos do direito societário brasileiro e limitação da autonomia privada) foi apresentado.

2. Cumpre dizer, porém, que as inquietações intelectuais ligadas a esses temas têm raízes mais antigas. Desde o curso de graduação e os primeiros passos na advocacia societária, no final dos anos 90, inquietava-nos notar que não havia obras de direito societário tratando de contratos celebrados entre sócios (salvo aquelas lidando sobre acordos de acionistas), ao passo que, quotidianamente, eram múltiplas as hipóteses desses contratos com que a jovem estudante se deparava (acordos de financiamento à sociedade, contratos sobre a compra e venda de participações, contratos de associação e joint venture, contratos de fornecimento de tecnologia, etc.). Qual a influência do direito societário sobre esses contratos? Seriam as partes totalmente livres para estipulá-los, desde que respeitadas as condições gerais de validade do negócio jurídico ou haveria restrições próprias do direito societárioº

\footnotetext{
${ }^{1}$ A propósito da locução "pacto parassocial" em lugar de "contratos parassociais", optou-se por adotá-la em respeito a seu uso generalizado. Por outro lado, a palavra "pacto" traz em si a ideia de lateral, acessório a algo que é principal e, muito embora talvez seja essa a razão para sua utilização quanto aos ajustes extraestatutários, não se tencionou enfatizar esse aspecto. No texto, portanto, utilizar-se-á indistintamente "pactos" ou "contratos" parassociais.

${ }^{2}$ Semelhante questionamento é feito por ANA Felipa Leal: "O problema a analisar é, assim o de saber se, para além dos limites genéricos à autonomia privada, os acordos parassociais estão ainda sujeitos aos limites típicos do contrato de sociedade" (Algumas notas sobre a parassocialidade no direito português, in Revista de Direito das Sociedades, I, pp. 157). No Capítulo 4 ver-se-á que menos o contrato de sociedade e mais o relacionamento por ele gerado e sua lógica própria é que, ora se argumenta, impõe
} 
3. Buscando criar arcabouço teórico que pudesse apresentar respostas a indagações desse gênero, não se encontrava, à época, obras que expusessem ou sistematizassem as regras gerais, os princípios de direito societário que, violados, determinariam a nulidade do ato ou negócio jurídico, ou obras que tratassem os contratos parassociais de forma específica e abrangente ${ }^{3}$.

4. Passados mais de dez anos, constata-se com pesar que a doutrina brasileira ainda se ressente de trabalhos de teoria geral do direito societário, que enunciem, de maneira sistemática, seus princípios estruturais, funcionais, valorativos e a lógica própria desse ramo do direito ${ }^{4}$. Ao contrário, a recente produção científica em direito societário, no Brasil, tem se concentrado na descrição dos tipos societários e no exame de temas específicos a eles ligados 5

peculiaridades ao processo interpretativo a ser seguido quanto aos pactos parassociais patrimoniais.

3 Sobre a disciplina da nulidade do contrato de sociedade e de atos societários, como a deliberação assemblear, a literatura é vasta e bem conhecida a peculiaridade da anulação. Cf. o clássico de JOSEPH HÉMARD, Théorie et pratique des nullités de sociétés et des sociétés de fait, Paris, Sirey, 1926 e ERASMo VALladão AZEvedo E NovAES FrançA, Invalidade das deliberações de assembléia das S.A., São Paulo, Malheiros, 1999. Pouco se fala, contudo, da nulidade que atinge contratos outros celebrados entre sócios. Haveria também com relação a eles que se matizar as regras de nulidade (para proteção de terceiros de boa-fé, por exemplo) ou o fato de serem celebrados no contexto de um relacionamento societário em nada influencia a possibilidade de sua anulação? Dúvidas como essa são a base da tese.

4 A exemplo das obras de Herbert WIEDEMAnn, Gesellschaftsrecht I - Grundlagen München, Beck, 1980; KARSTEN SCHMIDT, Gesellschaftsrecht. $4^{\mathrm{a}}$ ed., Köln, Heymanns, 2002; António Menezes Cordeiro, Manual de direito das sociedades. - Das sociedades em geral., Vol. 1, Coimbra, Almedina, 2004 e Yves GuYon, Les sociétés - Aménagements statutaires et conventions entre associés, in Traité des Contrats, Jacques Ghestin (coord.),

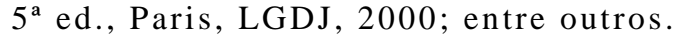

${ }^{5}$ Nesse passo, incisivas as palavras de Menezes Cordeiro, a respeito da verificação do mesmo limitador, no direito português: "[n]a fixação de uma dogmática das sociedades encontramos um dilema: deve-se insistir numa construção de conceitos gerais ou passar a uma descrição dos tipos de sociedades, mais simples e directa? Esta última opção tem sido privilegiada em exposições de cariz muito elementar ou em textos dirigidos a não-juristas. Ela domina, ainda, nalguma doutrina portuguesa tradicionalista, que trabalha com classificações elementares e passa, depois, a uma exegese de áreas mais conhecidas da parte geral do Código de Sociedades Comerciais. Não é satisfatória. Além do retrocesso científico e cultural que implica, ela não pode assegurar um progresso na Ciência do Direito das sociedades. Além disso, abdica de uma verdadeira dimensão doutrinária, na tradição universitária do ensino do Direito no Ocidente Continental. A construção geral é mais ambiciosa, sendo adoptada pelos melhores tratadistas da matéria". (Manual de direito das sociedades - Das sociedades em geral, Vol. 1, Coimbra, Almedina, 2004. p. 179). GUYON também enuncia no início de sua obra (Les sociétés, cit., p. 9), que seria inútil 
em dinâmica que, aliás, pode também ser verificada quanto aos contratos comerciais ${ }^{6}$.

5. A ausência de manifestações doutrinárias como as acima apontadas, por decorrência, frequentemente torna pouco claro, ao intérprete, o espaço de exercício da autonomia privada que os fundamentos e princípios próprios do direito societário deixam entrever ${ }^{7}$.

6. Nesse contexto, como será reiterado incontáveis vezes ao longo da tese, o que havia - e há - a respeito de contratação entre sócios, no Brasil, diz respeito ao próprio contrato de sociedade ou, em sede parassocial, ao acordo de acionistas, previsto na Lei n. 6.404/76.

7. Decidiu-se, assim, restringir o projeto de pesquisa inicial, alterando seu foco para o tema dos contratos parassociais, pois essa opção pareceu a um só tempo útil e realista, no sentido que permitiu que se continuasse a examinar a relação entre autonomia privada e direito societário, sem que a pesquisa que se considerou inicialmente realizar sobre os princípios do direito societário brasileiro acabasse por se mostrar incompatível com as limitações de tempo para a conclusão do doutoramento.

8. Feito esse corte metodológico inicial, optou-se por realizar, como primeiro passo para o desenvolvimento do trabalho, levantamento

escrever uma obra que uma vez mais descrevesse o regime legal das sociedades, pois a doutrina é, deste ponto de vista, abundante.

${ }^{6}$ De fato, como esclarece PAula A. Forgioni, ao tratar de contratos empresariais, "não há um esforço dogmático para a compreensão do mecanismo de funcionamento comum desses negócios; tampouco, encontramos o desenvolvimento de conceitos aptos para explicá-los em sua lógica peculiar" (Teoria geral dos contratos empresariais, São Paulo, RT, 2009 , p. 17-20). À mesma conclusão chega-se com relação aos pactos parassociais, como se verá ao longo desta tese.

${ }^{7}$ GUYON aponta mesmo como objetivo de seu trabalho "a busca do lugar ocupado pela vontade individual e pela liberdade contratual no direito societário", o que seria conveniente empreender também com relação ao direito brasileiro. Em especial quanto aos pactos parassociais, é preciso avaliar quais princípios devem ser respeitados na redação e execução (Les sociétés.., cit., p.9). 
bibliográfico e jurisprudencial, no $\mathrm{Brasil}^{8}$, com relação a pactos parassociais e, por consequência, acordos de acionistas. Os principais termos utilizados para a pesquisa foram "parassocial"; "acordo de acionistas"; "sindacati di voto", "pactes d'associés", buscando identificar o conteúdo das obras consultadas a seu respeito.

9. Na doutrina, partiu-se de nossos clássicos, perpassando comentários às leis; (ii) manuais; (iii) tratados; (iv) monografias ${ }^{9}{ }^{10}$;

\footnotetext{
${ }^{8}$ Cabem aqui os agradecimentos, uma vez mais, à generosidade do Prof. José Alexandre TAVARES GUERREIRo por permitir o acesso à sua rica biblioteca, em que foi possível consultar obras-chave para o desenrolar da pesquisa.

${ }^{9}$ No que diz respeito à doutrina brasileira, houve preocupação em realizar um panorama cronológico das grandes obras do direito comercial pátrio, de modo a tentar identificar em que momento histórico o questionamento sobre pactos parassociais surgiu. Desta forma, em ordem de publicação, estas foram as obras fundamentais consultadas com esse propósito (outras estão listadas na seção "referências bibliográficas"): José DA SILva LiSBoA, (Visconde de Cairu), Principios de direito mercantil e leis de marinha, $6^{\mathrm{a}}$ ed., Rio de Janeiro, Acadêmica, 1874; Salustiano Orlando de Araújo Costa, (o Conselheiro Orlando), Codigo Commercial do Imperio do Brazil, Rio de Janeiro, Laemmert, 1864; Didimo Agapito Da Veiga Junior, As sociedades anonymas (Lei n. 3.150 , de 4 de novembro de 1882 - Commentario), Rio de Janeiro, Nacional, 1888; Didimo AgAPITO DA Veiga Junior, Codigo Commercial commentado, Rio de Janeiro, Laemmert, 1898; José DA Silva Costa, Direito commercial maritimo, Rio de Janeiro, Jornal do Commercio, 1899; Antonio Bento de Faria, Codigo Commercial brazileiro, Rio de Janeiro, Ribeiro dos Santos, 1903; Herculano Inglez De Souza, Direito commercial (prelecções professadas na Faculdade Livre de Sciencias Jurídicas e Sociaes do Rio de Janeiro e compiladas pelo bacharel Alberto Biolchini), São Paulo, Escolas Profissionaes Salesianas, 1906; BRAsilio Augusto Machado De Oliveira, (o Barão Brasilio Machado), O Codigo Commercial do Brasil em sua formação histórica, São Paulo, Salles, 1910; José Xavier CARvalho DE Mendonça, Tratado de direito commercial brazileiro, Vol. 1, $1^{\text {a }}$ ed., São Paulo, Cardozo Filho, 1910; Salvador Antonio Moniz Barreto de Aragão, Sociedades anonymas, Rio de Janeiro, Francisco Alves, 1914; SPENCER VAMPRÉ, Das sociedades anonymas commentario à consolidação das leis sobre sociedades anonymas e em commandita por acções (Decr. n. 434 de 4 de julho de 1891), São Paulo, Pocai-Weiss, 1914; DesCARTES DE Magalhães, Curso de direito comercial, Vol. 1, $1^{\text {a }}$ ed., Salvador, Bahiana, 1919; SPenCer VAMPrÉ, Tratado elementar de direito commercial, 3 v., Rio de Janeiro, Briguiet, 1922; Alfredo de Almeida Russel, Curso de direito commercial brasileiro, Rio de Janeiro, Scientifica, 1923; Waldemar Ferreira, Curso de direito commercial, Vol. 2., São Paulo, Salles Oliveira, 1927; Alfredo De Almeida Russel, Sociedades anonymas: theoria e pratica, Rio de Janeiro, Leite Ribeiro, 1929; Octavio Mendes, Curso de direito commercial terrestre, São Paulo, Saraiva, 1930; José XAVIer CARVAlho De MendonçA, Problemas das sociedades anonymas, São Paulo, RT, 1931; Gudesteu DE SÁ Pires, Sociedades anonymas (subsidios para a reforma da lei), Rio de Janeiro, Jornal do Commercio, 1935; Trajano de Miranda Valverde, Sociedades anonimas, Vol. 1, Rio de Janeiro, Borsoi, 1937; TRAJANo DE MIRAnda VAlverde, Sociedades por ações (comentários ao Decreto-Lei n. 2.627, de 26 de setembro de 1940), Vol. 2, Rio de Janeiro, Revista Forense, 1941; Gudesteu de Sá PIREs, Manual das sociedades anonimas, Rio de Janeiro, Freitas Bastos, 1942; WALDEMAR FERREIRA, Instituições de direito comercial, Vol. 1, Rio de Janeiro, Freitas Bastos, 1944; Antonio Bento DE Faria, Direito comercial,
} 
pareceres publicados ${ }^{11}$ e (vi) $\operatorname{artigos}^{12}$. Na jurisprudência, examinou-se decisões do Superior Tribunal de Justiça e Supremo Tribunal Federal ${ }^{13}$.

Rio de Janeiro, Coelho Branco, 1947; WALDEMAR FERREIRA, Tratado de direito comercial, Vol. 8, São Paulo, Saraiva,1960-2; CARlos Fulgêncio Cunha Peixoto, Sociedades por ações (comentários ao Decreto-lei n. 2.627, de 26 de setembro de 1940, com as alterações da Lei n. 4.728, de 14 de julho de 1965, Lei do Mercado de Capitais), Vol 5, São Paulo, Saraiva, 1972-3; FRAN MARTINs, Curso de direito comercial, Ceará, Universitária, 1957; Wilson de Souza Campos Batalha, Comentários à Lei das Sociedades Anônimas, Vol. 2, Rio de Janeiro, Forense, 1977; Egberto LACERda Teixeira e José Alexandre Tavares Guerreiro, Das sociedades anônimas no direito brasileiro, Vol. 2, São Paulo, Bushatsky, 1979; OSMAR BRINA CORREA-Lima, Direito de voto na sociedade anônima, in RT 530 (dez. 1979), pp. 26-37; Luiz GASTÃo PAES De BARros Lẽ̃es, Comentários à Lei das Sociedades Anônimas, Vol. 2, São Paulo, Saraiva, 1980. Ainda no que tange à doutrina brasileira, buscou-se identificar as obras monográficas sobre o tema aqui publicadas, localizando-se cinco principais trabalhos até o momento: Celso De AlbuQuerque Barreto, Acordo de Acionistas, Rio de Janeiro, Forense, 1982; Modesto Carvalhosa, Acordo de Acionistas, São Paulo, Saraiva, 1984; Celso Barbi Filho, Acordo de Acionistas, Belo Horizonte, Del Rey, 1993; Jõ̃o Luiz Coelho Da Rocha, Acordo de Acionistas e Acordo de Cotistas, Rio de Janeiro, Lumen Juris, 2002; Marcelo M. Bertoldi, Acordo de Acionistas, São Paulo, RT, 2006. Em 2011, no decorrer da redação final do trabalho, foi publicada a obra de Modesto Carvalhosa, Acordo de Acionistas - Homenagem a Celso Barbi Filho, São Paulo, Saraiva, 2011.

${ }^{10} \mathrm{Na}$ doutrina estrangeira, foi possível consultar as seguintes obras monográficas: GiORGIO OpPo, Contratti parasociali, Milano, Vallardi, 1942; LUIGI FARENGA, I contratti Parasociali, Milano, Giuffrè, 1987; Giuseppe Santoni, Patti parasociali. Napoli, Jovene, 1985; JÜRGEN Dohm, Les accords sur l'exercice du droit de vote de l'actionnaire. Geneve, Librairie de l'université Georg \& Cie S.A, 1971; AnTONio PEDRol, La anónima actual y la sindicación de acciones, Madrid, Revista de Derecho Privado, 1969; Gastone CotTINO, Le convenzioni di voto nelle società commerciali, Milano, Giuffré, 1958; MARIO LEITE SAnTos, Contratos parassociais e acordos de voto nas sociedades anónimas, Lisboa, Cosmos, 1996.

11 Entre os repertórios que mais contribuíram ao desenvolvimento das pesquisas, estão: FÁbio Konder Comparato, Direito empresarial: estudos e pareceres, São Paulo, Saraiva, 1990; FÁBIO KONDER COMPARATO, Novos ensaios e pareceres de direito empresarial, Rio de Janeiro, Forense, 1981; LUIS GASTÃo PAES DE BARROS LEÃES, Estudos e pareceres sobre sociedades anônimas, São Paulo, RT, 1989; LUIS GASTÃo PAES DE BARROS LEÃES. Pareceres, Vol. 2, São Paulo, Singular, 2004; Alfredo LAmy Filho e José Luiz Bulhões Pedreira, A Lei das S.A., Rio de Janeiro, Renovar, 1992; Alfredo Lamy Filho, Temas de S.A.: exposições, pareceres, Rio de Janeiro, Renovar, 2007; ANTONIO JUNQUEIRA DE AzEvedo, Estudos e pareceres de direito privado, São Paulo, Saraiva, 2004; ANTONIO Junqueira De AzEvedo, Novos estudos e pareceres de direito privado, São Paulo, Saraiva, 2009. Alfredo Lamy Filho e José Luiz Bulhões Pedreira, José Luiz, Direito das Companhias, Rio, Forense, 2009.

12 Provenientes de levantamento na base de dados eletrônica IUSDATA, bem como extraídos da leitura das principais monografias sobre o tema de contratos parassociais.

${ }^{13} \mathrm{Na}$ seção REFERÊNCIAS JURISPRUDENCIAIS encontra-se o panorama geral dos resultados do TJSP não foram citados todo os acórdãos consultados porque a maioria deles apenas tangenciam o problema a ser tratado na presente tese, como se verá mais adiante. Analisouse, então, apenas os poucos acórdãos relevantes, de todas as cortes pesquisadas, que podem ser encontrados na seção "ANÁlisES JURISPRUDENCIAIS", onde também se encontram os 
10. Com relação aos artigos de doutrina, o intento inicial era o de realizar pesquisa manual, "capa a capa", das principais revistas de direito comercial, tendo em vista que (i) os índices, quando existentes, não são frequentemente atualizados. (ii) revistas antigas não têm seus artigos catalogados, um a um, nos programas de pesquisa, demandando conferência física e (iii) essa modalidade de pesquisa permite que se obtenha panorama da produção doutrinária sobre determinado tema e também dados estatísticos sobre a sua verificação.

11. Contudo, a paralisação das atividades da Biblioteca de Direito Comercial da Faculdade de Direito da Universidade de São Paulo durante a maior parte do ano de 2010 inviabilizou a pesquisa pretendida. Por consequência, os artigos consultados no Brasil foram, substancialmente, aqueles apontados pela base de dados eletrônica IUSDATA, cujas cópias foram obtidas antes do fechamento da biblioteca, além de alguns artigos referidos nesses primeiros textos e nas demais obras consultadas.

12. Julga-se oportuno indicar, sucintamente, as conclusões obtidas ao cabo do levantamento em questão:

(i) evolução na doutrina: pode-se dividir a evolução doutrinária do tema dos contratos parassociais, no Brasil, em quatro grandes fases.

A primeira fase, compreendida nos clássicos tratados, enfoca o contrato de sociedade como reflexo ou sinônimo do relacionamento

\footnotetext{
parâmetros de pesquisas e a porcentagem aproximada dos temas tratados nos acórdãos. Em específico, com relação ao Tribunal de Justiça do Estado de São Paulo, o levantamento de acórdãos é tarefa que importa dificuldades de precisão e abrangência. Visto que a digitalização de seus julgados ainda está em fase de implementação, a pesquisa em suas bases de dados eletrônicas é não raro falha (vez que os mecanismos de buscas não se mostram de todo confiáveis pela desarmonia na indexação de julgados) e limitada no tempo (de modo que acórdãos mais antigos devem ser identificados manualmente nos repertórios oficiais). Pelas dificuldades apontadas, não se adotou a análise jurisprudencial como elemento central da linha metodológica seguida, que se fixou, precipuamente, no exame da doutrina. Essa escolha não afasta, porém, o interesse em se realizar trabalho específico, em outra sede, em que os esforços sejam direcionados exclusivamente à análise jurisprudencial completa do tema dos pactos parassociais e/ou acordos de acionistas no Brasil.
} 
societário e apenas marginalmente aponta a possibilidade de contratação que com ele não coincida ${ }^{14}$. No Brasil, as principais referências são os comentários ao art. 302 do Código Comercial de 1850.

A segunda fase, correspondente às primeiras décadas do Século XX, contempla a discussão sobre acordos de voto. Entre nós, ficou célebre o Caso Martinelli, de 1924, cujo deslinde judicial contou com pareceres da lavra de expoentes brasileiros como EdUARDo EsPínOla, Carvalho de Mendonça e Clóvis Bevilacqua ${ }^{15}$. Centrava-se o caso na discussão sobre a validade de acordo de voto mediante o qual se convencionava a indicação de diretor de sociedade anônima. As questões fulcrais para sua decisão, contudo, mais que no exame de validade da vinculação do voto, centraram-se na validade da indicação $e$ revogação de administradores em acordo de voto. Com o estudo desse caso, foi possível depreender a mentalidade do início do século com relação a temas tão importantes para a teoria ligada aos contratos parassociais, em específico, os acordos de voto.

O período de vigência do Decreto 2.324/40 representa a terceira fase de apreciação do problema, tendo em vista a expansão da utilização de acordos de voto e outros acordos de acionistas no pós-guerra e, de outro lado, a ausência de regra legal específica, no Brasil, sobre acordos de acionistas e sua validade. É nesse período que, justamente em virtude do prestígio que os pactos parassociais passam a ostentar, Giorgio Oppo publica a obra pioneira para o tema, Contratti Parasociali, em $1942^{16}$.

\footnotetext{
${ }^{14}$ As obras consultadas não continham seção específica sobre contratos entre sócios ou mesmo acordos de voto.

${ }^{15}$ Cf. Revista de direito civil, commercial e criminal 87 (jan. 1928), pp. 460-500; 532-37; 600-10; e Pandectas brasileiras 2, pt. 2, pp. 517 e ss.

${ }^{16}$ Contratti Parasociali, Milano, Vallardi, 1942.
} 
Por fim, a última fase inicia-se com a promulgação da lei 6.404/76, que trouxe disposição expressa sobre acordos de acionistas e, na doutrina, é marcada pelas discussões sobre a opção adotada pelo legislador ${ }^{17}$. Nessa fase, surgem monografias específicas sobre o tema acordo de acionistas ${ }^{18}$.

Conclui-se, então, que o contexto econômico mundial, o intenso fluxo de relações comerciais e societárias propiciado pela globalização e a própria evolução pela qual o direito societário passa nos últimos vinte anos - em que proliferam as "joint ventures" internacionais e os investimentos de "private equity" em sociedades anônimas fechadas exige que nova fase se inicie na compreensão de contratos parassociais, de modo a compreendê-los na sua real motivação e utilização no bojo dos mais diversos relacionamentos empresariais.

(ii) tratamento específico do tema em obras de caráter geral (tratados $e$ manuais de direito comercial): feitas as considerações acima, verificou-se que as poucas obras de conteúdo panorâmico que efetivamente tratam de contratos parassociais, cuidam precipuamente dos acordos de voto e seus problemas próprios ou, se posteriores a 1976, referem-se a acordos de acionistas. Em ambos os casos, porém, não se discute a repercussão, sob a ótica societária, de contratos com conteúdo exclusivamente patrimonial (e não político) celebrados por

\footnotetext{
17 Nesse sentido, pertinente a conclusão de CAlixto SAlomão FIlho: “[a] discussão em torno do acordo de acionistas tem se centrado nos últimos anos em torno de temas aplicativos. A preocupação central tem sido a discussão dos efeitos, abrangência e consequências do acordo, tudo naturalmente precedido da tradicional e inafastável análise de sua natureza jurídica" (Acordo de Acionistas como instância da estrutura societária, in O Novo Direito Societário, $3^{a}$ ed. reformulada, São Paulo, Malheiros, 2002, p. 94. O artigo do autor, a propósito, é dos únicos orientados à análise do acordo de acionistas pela perspectiva de sua função no direito societário - e não apenas como um contrato ("A presente discussão tem uma proposta metodológica diversa. O ponto de partida é o raciocínio teórico sobre a função do acordo de acionistas dentro do sistema societário, proposta, portanto, eminentemente teórica". Idem, ibidem).
}

${ }^{18}$ Para lista das principais monografias, cf. nota \#, acima. 
sócios. Por fim, é constante a referência a OpPO e ao que propôs na obra Contratti Parasociali de $1942^{19}$.

(iii) monografias: as principais monografias sobre o tema versam sobre o acordo de acionistas previsto na lei 6404/76. Não foram encontradas monografias brasileiras sobre pactos parassociais enquanto gênero de que o acordo de acionistas é espécie.

(iv) jurisprudência: a jurisprudência sobre acordo de acionistas não é vasta e, quando as decisões não são centradas em aspectos de direito processual, referem-se a questões ligadas ao voto ${ }^{20}$. Outra conclusão é o patente descompasso entre a extensa utilização de contratos parassociais na realidade negocial e as raras decisões jurisprudenciais que os tem em mira. O sigilo dos pactos parassociais e sua submissão à arbitragem são fatores que impedem o acesso às decisões em lides que os envolvem.

13. Tendo obtido os resultados acima, partiu-se para temporada de pesquisa de 3 meses (junho, julho e agosto de 2010) no Max-Planck-Institut für ausländisches und internationales Privatrecht em Hamburgo, Alemanha, que concedeu bolsa de estudos para o projeto intitulado Contractualisation of Company Law: An European Perspective.

14. Durante o período em Hamburgo, realizou-se levantamento doutrinário sobre o tema da contratação parassocial, com a oportunidade única de discuti-lo com o Prof. Klaus J. Hopt, com pesquisadores-sênior da entidade

\footnotetext{
${ }^{19}$ Cabe salientar a perspectiva dos contratos parassociais para o tema do poder de controle, apresentada pelo Prof. FÁBio Konder Comparato mesmo antes da Lei n. ${ }^{\circ}$ 6.404/76, nas primeiras edições da obra $O$ poder de controle nas sociedades anônimas.

${ }^{20}$ Há, contudo, decisões que tocam aspectos relevantes para o enfoque que se procura conferir ao presente trabalho, sendo necessária a análise da decisão do STJ, RESP 388.423RS, Quarta Turma, rel. Min. Salvio De Figueiredo TeiXeira, j. 13.5.03, que se encontra na seção ANÁlises JURISPRUDENCIAIS, ao final do trabalho.
} 
(Drs. Felix Steffek; Walter Doralt e Jan Peter Schmidt) e demais bolsistas e pesquisadores ${ }^{21}$.

15. Ao final do primeiro mês de levantamento bibliográfico na vasta biblioteca do Instituto ${ }^{22-23}$, de debates com pesquisadores, bem como de aprofundamentos sobre o que já se trazia do Brasil, tendía-se a eleger como hipótese de trabalho a proposta de avançar no que OpPo fizera em 1942 e dotar a expressão “contratos parassociais" de conteúdo mais amplo, alinhado à posição de GUYON, para quem a sociedade deve ser vista como a estrela maior (mas não única) de uma nebulosa contratual que a cerca, havendo interação e influência mútua entre ambas ${ }^{24}$.

16. Refletia-se, para embasar a linha de pesquisa, que esses contratos, celebrados ao redor da sociedade, devem respeito ao direito societário, ainda que eles não estejam diretamente ligados à organização da sociedade, que é o principal critério adotado por OPPO para determinar a peculiaridade ínsita aos

\footnotetext{
${ }^{21}$ Agradecimentos, em especial, às colegas Elena de Carvalho Gomes, Doutora em Direito Civil na Universidade Federal de Minas Gerais, sob a orientação do Prof. João Baptista Villela e na Universidade de Pisa, e Catarina Monteiro Pires, doutoranda em Direito Civil na Universidade de Lisboa, sob a orientação do Prof. Dr. Pedro Pais de Vasconcelos, pelo intenso debate intelectual do qual resultou a opção por enfocar apenas os pactos parassociais patrimoniais (e não os ajustes de voto) como objeto da tese.

${ }^{22}$ Com grata surpresa, deparou-se no Instituto com a coleção das nossas principais revistas jurídicas. Dessa maneira foi possível, ao menos com relação a Revista de Direito Mercantil, realizar o levantamento panorâmico a que acima se referiu, obtendo a frequência de produção no tema de contratos parassociais nessa importante publicação brasileira. Esse levantamento confirmou o que a pesquisa realizada no Brasil já apontava: preponderância de artigos tratando de aspectos específicos dos acordos de acionistas e, mais especialmente, acordos de voto. De fato, não se identificou artigos que examinassem (i) os pactos parassociais como gênero e/ou (ii) os acordos parassociais centrados em direitos individuais dos sócios pelo viés do direito societário. Infelizmente, não houve tempo hábil para realizar o mesmo levantamento panorâmico com relação à Revista dos Tribunais, desde seu número 1, ou ainda a Revista Forense.

${ }^{23}$ Vale referir algumas obras consultadas, sobretudo francesas e alemãs, que contribuíram significativamente para o refinamento do tema da tese: Felix Christopher Hey, Freie Gestaltung in Gesellschaftsverträgen und ihre Schranken, München, Beck, 2004; JEANJacques Daigre e Monique Sentilles-Dupont, Pactes d'Actionnaires, Paris, Joly, 1995; JEAN-PhILIPPE DOM, Les montages en droit des sociétés. In Pratique des affaires. Paris, Joly, 1995; Claudio Köhler, Nebenabrede im GmbH und Aktienrecht - Zulässigkeit und Wirkung, Frankfurt am Main, Lang, 1992.
}

${ }^{24}$ Les sociétés... cit., p. 303, in verbis: "La société est ainsi comparable à l'étoile majeure d'un nebuleuse contractuelle". 
contratos parassociais. Estar-se-ia a configurar os contratos parassociais, sob essa ótica, como algo próximo a "contratos relevantes para o direito societário".

17. Partiu-se, então, para a configuração da tese com vistas a essa orientação tendo sido encontrados argumentos e base doutrinária para explorá$10^{25}$. Todavia, a principal dificuldade que se pôs então foi a de tratar, em uma única tese, de acordos dos quais facilmente se reconhece a necessidade de sua submissão ao direito societário e muito já se produziu em doutrina (acordos de voto) e aqueles pactos ou ajustes, entre sócios, que em princípio dizem respeito apenas a direitos individuais seus - e nada ou pouco influenciariam na vida da sociedade ou sua organização ${ }^{26}$.

18. E é justamente sobre os últimos que o interesse em cotejar com a lógica própria do relacionamento entre sócios e com os princípios de direito societário se mostrou mais interessante: raríssimas obras ${ }^{27}$ os observam sob essa perspectiva, no sentido de matizar a autonomia contratual em prol dos alvos de tutela desse ramo do direito, ou mesmo tendo em conta a relação societária efetivamente desejada pelas partes e suas específicas demandas.

Entende-se que esse questionamento é válido e deve ser feito, ainda que, ao final e em cada caso específico, conclua-se que os contratos sob exame não têm efetivo potencial de lesão aos alvos de tutela da disciplina e/ou de desvirtuamento da relação societária, ou ainda, não seja possível impor

\footnotetext{
25 Vide, por exemplo, CHRistoph Weber, Privatautonomie und Außeneinfluß im Gesellschaftsrecht, Tübingen, Mohr Siebeck, 2000.

${ }^{26}$ Também seria necessário examinar a hipótese de contratos celebrados com não sócios, os quais pudessem produzir efeitos relevantes para o direito societário (por exemplo, acordos de cooperação, acordos com dirigentes ou acordos com credores) o que alargaria demais o campo de investigação e talvez desviasse o foco da principal questão que motivou a pesquisa: os limites da autonomia contratual na configuração de um relacionamento societário.

${ }^{27}$ Como as obras de Yves Guyon, Les sociétés..., cit.; Sophie SChiller, Les limites de la liberté... cit.; bem como LAURENT CONVERT, L'imperatif et le supplétif dans le droit des sociétés, Paris, LGDJ, 2003 e GÉRALdine GoffauX-CAllebaut, Du contrat en droit des sociétés, Paris, L'Harmattan, 2008.
} 
restrições à autonomia contratual na celebração desses pactos, a menos que haja previsão legal expressa, em nome da segurança jurídica ${ }^{28}$.

19. Novo corte metodológico foi, então, necessário: o exame de contratos parassociais que não disciplinam direitos políticos dos sócios (e com isso influenciam a organização da sociedade), mas direitos patrimoniais e individuais que, em tese, ouvidos os ecos do individualismo contratual do Século $\mathrm{XIX}^{29}$, poderiam ser livremente dispostos e alienados por seus titulares.

Trata-se, afinal, de averiguar os termos em que esses contratos devem receber restrições advindas seja da necessidade de respeito a interesses de terceiros e, claro, dos próprios sócios, signatários ou não (tutelados por aquilo que os franceses convencionam designar por "ordem pública societária") $)^{30}$, como também decorrentes da própria noção de sociedade e dos deveres e direitos a ela correlatos.

20. Diante dessa nova correção de rota na pesquisa, o tempo que restava no Instituto foi utilizado para colher material correspondente. A oportunidade de reflexão permitida pelo período no exterior, no ano de 2010, foi fundamental para que o trabalho pudesse ser segmentado e adaptado às reais dimensões de uma tese de doutorado, reservando para futuros projetos os outros aspectos do amplo tema da autonomia contratual no direito societário, linha de pesquisa que tanto nos fascina.

21. Por ocasião do exame de qualificação, as contribuições da banca formada pelos Prof. Drs. Paula A. Forgioni, José Alexandre Tavares Guerreiro

\footnotetext{
${ }^{28}$ Consoante será exposto no item 1.3, na generalidade das legislações consultadas, não se encontram disposições legais específicas no que se refere à validade dos contratos parassociais ou a parâmetros para sua interpretação.

${ }^{29}$ Cf., ainda Paula A. Forgioni, A evolução do direito comercial brasileiro: da mercancia ao mercado, São Paulo, RT, 2009. p. 218.

${ }^{30}$ Nesse ponto, e no reverso da moeda, toca-se o tema da produção de efeitos contratuais perante terceiros. No direito brasileiro, necessária a consulta a LUCIANO CAMARGO Penteado, Efeitos contratuais perante terceiros, São Paulo, Quartier Latin, 2007.
} 
e Francisco Satiro de Souza Jr. foram significativas e realçaram a ainda persistente amplitude do tema, demandando nova reflexão sobre o enfoque a ser adotado.

22. Assim, após avaliar as ponderações feitas e o material de pesquisa recolhido, decidiu-se por delimitar o trabalho elegendo como ponto fulcral da tese a discussão e propositura de elementos que devem orientar a interpretação dos contratos parassociais patrimoniais em detrimento de uma análise de sua natureza e/ou um seu possível enquadramento em uma categoria dogmática.

A matriz para a reflexão empreendida, nesses termos, é a função econômica de referidos pactos e o modo pelo qual integram o estado de sócio ${ }^{31}$ de seus pactuantes, no contexto da relação societária existente entre eles, visto que são fundamentos para a superação de leitura meramente obrigacional dos pactos parassociais patrimoniais, tocando aspectos básicos do direito societário.

\footnotetext{
${ }^{31}$ Neste trabalho perfilha-se a posição de Menezes Cordeiro ao adotar a expressão de estado de sócio para designar sua posição jurídica, como se verá no Capítulo 4. A respeito, afirma BRUNeTti, apoiado em DALMARTEllo, que "se poderia falar aqui de "posição jurídica do sócio na sociedade' mas parece mais eficaz, também porque o relacionamento é geralmente de longa duração, manter a expressão 'estado de sócio' como aquela que melhor indica o conjunto de deveres e direiros, das funções e poderes cabentes ao sócio na sociedade ou perante a sociedade ("[s]i potrebbe parlare qui di "posizione giuridica del socio nella società' ma sembra più efficace, anche perchè il rapporto è generalmente di durata, mantenere l'espressione 'stato di socio' come quella che meglio indica linsieme dei doveri e dei diritti, delle funzioni e dei poteri spettanti al socio nella società o verso la società". Trattato del Diritto delle Società, 2a. Ed. Tomo I, Milano, Giuffré, 1948, p 221). Contra o uso da expressão, Aníbal SAnchez, ao tratar sobre os direitos de sócio, afirma "quedó así determinado em términos jurídico-positivos el lado activo de lo que, con alguna impropriedad, acostumbra a designarse todavia hoy como el status socii (...); una situación que, bien miradas las cosas, es preferible calificar como una cualidad o posición subjetiva, compuesta de todo un haz de relaciones jurídicas. Se trata, en todo caso, de una posición compleja y, por lo general, no estrictamente personal sino fungible, dotada de menor estabilidad y mayor polivalencia que la que distingue a los llamados fenomenos de estado en sentido estricto - por lo demás igualmente controvertidos (pensemos como paradigma en el 'estado civil') La accion y los derechos del accionista (art. 47 a 50 LSA) in RodRIGO Uria, Aurelio Menenzes y Manuel Olivencia (org). Comentario al regimen legal de las sociedades mercantiles, Tomo IV, Vol. 1, Madrid, Civitas, 1994, p. 99. Entre nós esclarece WALDIRIO BULGARELli que "não é pacífica na doutrina a aceitação do termo 'status' para qualificar os direitos e deveres do acionista, terminologia defendida por Ascarelli e aceita em geral pela doutrina italiana" (A Proteção às Minorias na Sociedade Anônima, São Paulo, Pioneira, 1977, p. 28).
} 


\section{Justificativa e contribuição original à ciência jurídica brasileira}

21. Como se evidenciou acima e também na Introdução que segue, a tese Pactos Parassociais Patrimoniais. Elementos para sua interpretação no direito societário brasileiro justifica-se, principalmente, pela ausência de estudos doutrinários brasileiros aprofundados sobre o tema dos contratos parassociais e, no específico, quanto a pactos parassociais que regulem exclusivamente direitos patrimoniais e individuais dos sócios (e não seus direitos políticos).

Quanto a esses últimos, a contribuição inovadora estaria não apenas no corte metodológico realizado mas, sobretudo, no exame desses contratos pela perspectiva da relação societária sobre a qual se apóiam e/ou que deles deriva- e não pelo viés exclusivo do direito comum dos contratos.

Por fim, o próprio tema da interpretação dos pactos parassociais patrimoniais, com a tentativa de indicação de elementos caros à lógica societária e aos princípios e fundamentos do direito societário é inovador, não se tendo encontrado qualquer obra brasileira que o explore detidamente ${ }^{32}$.

Em vista desse enfoque, o conteúdo apresentado nos capítulos iniciais sobre o tema dos pactos parassociais não tem o objetivo de esgotar cada aspecto ali comentado, mas antes fornecer ao leitor premissas para a compreensão do cerne da discussão que se propõe, cujos argumentos são desenvolvidos no Capítulo 4.

\footnotetext{
32 Peggy Larrieu noticia a ausência de estudos, também na França, a respeito da interpretação de pactos parassociais, sempre mais comuns na prática societária ("[o]r, si la question de la validité et de l'efficacité des pactes extra-statutaires, dont l'actualité est toujours considérable, a maintes fois été traité, em revanche, celle de leur interprétation reste à ce jour inédite. Pourtant, elle présente des intérêts pratiques et théoriques considérables". L'interprétation des pactes extra-statutaires, in Revue des Sociétés 4, out.dez., 2007, p. 697-8. Grifou-se.).
} 
Com relação aos elementos apontados para balizar a interpretação dos pactos parassociais patrimoniais, no Capítulo 4, uma vez que se trata de construções teóricas sobre com base nos argumentos levantados, não se espera que sejam os únicos, como se evidenciará oportunamente.

Finalmente, cumpre esclarecer que o estudo não se valerá da perspectiva da nova economia institucional (NEI) e de noções ligadas ao movimento de análise econômica do direito (law and economicsi) pois se considera que esse estudo deve ser feito posteriormente, quando os resultados do exame dos pactos parassociais patrimoniais pelo viés ora proposto já tiverem sido convenientemente tratados e "decantados" na doutrina, podendo melhor servir de ponto de partida ${ }^{33}$.

\footnotetext{
33 A utilização dos métodos da Análise Econômica do Direito deve orientar-se pela prudência, como indica PAUla A. Forgioni em AED - Paranóia ou Mistificação?, in RDM 139, pp. 424-250. Entende-se conveniente indicar material consultado, que pode vir a servir em futuros estudos de pactos parassociais sob a ótica de law and economics: LUCIAN ARYE BEBCHUK, Limiting Contractual Freedom in Corporate Law: The Desirable Constraints On Charter Amendments in Harvard Law Review, Vol. 102, No. 8, (1989), pp. 1820-1860; do mesmo autor, The Debate on Contractual Freedom in Corporate Law, in 89 Columbia Law Review (1989), pp. 1395-1415; OLIVER HART, Contractual freedom in corporate law, articles and comments: an economist's perspective on the theory of the firm, in Columbia Law Review 89 (1989), pp. 1757 e ss; BERnARd S. BLACK, Is Corporate law Trivial?: A Political and Economic Analysis, Northwestern University Law Review Vol. 84, No. 2 (1990), pp. 543-593; Frank H. EAsterbrook e Daniel R. Fischel. R., The Economic Structure of Corporate Law, Cambridge, Harvard Univesity, 1991; HENRY

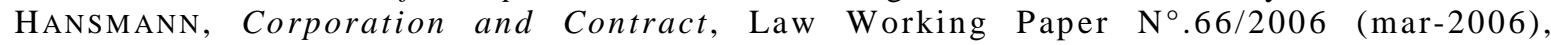
European Corporate Governance Institute, disponível em: http://ssrn.com/abstract=892830; REINIER R KRAAKMAN. et al., The anatomy of corporate law: a comparative and functional approach, New York, Oxford, 2004; RoBERTA ROMANO, Foundations of corporate law, New York, Foundation Press, 1993; JOHN ARMOUR et al., The essential elements of corporate law, Law working paper, n. ${ }^{\circ} 134, \quad 2009$, disponível em: http://ssrn.com/abstract=1436551; JOHN C. COFfEE JR e ADOLF. A. BerLe, The future as history: the prospects for global convergence in corporate governance and its implications, The Center for Law and Economic Studies Working Paper, n. ${ }^{\circ}$ 144, 1999, disponível em: http://papers.ssrn.com/paper.taf?abstract_id=142833.
} 


\section{INTRODUÇÃO}

Costuma-se afirmar que o direito societário tem por objetivo básico oferecer a disciplina das sociedades, considerando a necessária tutela de três grandes grupos de interesse: (a) os sócios/acionistas; (b) os credores da sociedade; e (c) demais terceiros que com ela interajam ou por ela possam ser $\operatorname{afetados}^{34}$. Com isso, deve permitir o desenvolvimento do mercado, a segurança e a previsibilidade com relação às formas societárias de exercício da atividade empresarial.

Desde as primeiras codificações, o fenômeno societário foi se expandindo e sofisticando ao sabor das exigências práticas dos agentes econômicos ${ }^{35}$. Nessa evolução, acoplaram-se paulatinamente à disciplina

\footnotetext{
34 Menezes CoRDeiro vai além, indicando entre os objetivos do direito societário: "a tutela dos sócios minoritários; o equilíbrio dos mercados; a transparência dos entes colectivos; a protecção de terceiros, designadamente credores; os direitos e a dignidade das pessoas; a concorrência; os valores básicos do ordenamento; a actuação fiscalizadora do Estado, mormente com escopos fiscais" (Manual de direito das sociedades, Vol. I, Coimbra, Almedina, 2004, p. 167). Na mesma linha, Herbert WiedemanN reúne os princípios valorativos ligados a esses três alvos de proteção por parte do direito societário no terceiro capítulo de sua clássica obra: o sócio individualmente considerado (Individualschutz), a minoria (Minderheitschutz), os investidores (Kapitalanlegerschutz), além dos interesses dos credores (Gläubigerinteressen) e dos trabalhadores (Arbeitnehmerinteressen). Cf. Gesellschaftsrecht, Vol. I, München, Beck, 1980. Para uma visão alinhada a movimento do law and economics, que não será adotada neste trabalho, sublinham HENRY HANSMANN e REINIER KRAAKMAN: "As a normative matter, the overall objective of corporate law - as of any branch of law - is presumably to serve the interests of society as a whole. More particularly, the appropriate goal of corporate law is to advance the aggregate welfare of a firm's shareholders, employees, suppliers, and customers without undue sacrifice - and, if possible, with benefit - to third parties such as local communities and beneficiaries of natural environment. This is what economists would characterize as to pursuit of overall social efficiency" (What is corporate law?, in REINIER KRAAKMAN et al., Anatomy of corporate law: a comparative and functional approach, New York, Oxford University, 2004, p. 18).

35 Esclarece, assim, SYLVIO MARCONDES MACHADO: “[a]s sociedades comerciais formamse, todas, por uma conjunção de capital e trabalho, mas exigem, para realização dos empreendimentos do comércio e da indústria, diferentes combinações desses elementos fundamentais, cabendo à ciência jurídica a composição das fórmulas necessárias. A história das sociedades comerciais está presta ao conjunto dos tipos criados, que
} 
original dos tipos societários ${ }^{36}$ regras relativas, por exemplo, aos grupos de sociedades, ao direito concorrencial e ao mercado de capitais - e, assim, o processo interpretativo passou a considerar esse novo cenário para além dos problemas intrínsecos às sociedades unitariamente consideradas .

A evolução contínua é traço característico do direito societário, ora alargando seu âmbito de incidência, ora afinando seu instrumental. Ramo do direito comercial, duas considerações podem demonstrar as raízes de sua particular dinamicidade.

A primeira liga-se ao fato de que os agentes econômicos sempre buscam a melhor acomodação possível de seus interesses, e, assim, com relação à sua atuação em sociedade, desenvolvem continuamente novas formas de utilizar os instrumentos jurídicos à sua disposição. Mais que isso, na falta de instrumento idôneo, criam-no. É a partir dessa constatação fática que o direito societário vai se reformulando, em processo indutivo, para acompanhar o que surge da prática dos agentes, sendo continuamente marcado pelos reflexos daquilo que sua criatividade gera no mercado ${ }^{37-38}$.

representam a satisfação jurídica de necessidades econômicas" (Ensaio sobre a sociedade de responsabilidade limitada, Tese de Livre-Docência, Faculdade de Direito da Universidade de São Paulo, São Paulo, 1940, p. 13. Destacou-se).

36 Conforme salienta Menezes Cordeiro, “[o] direito das sociedades não teve uma evolução do tipo racional. Ele antes adveio de uma paulatina evolução. (...) Os vários tipos de sociedades foram surgindo isoladamente, expandindo-se em função de coordenadas complexas e aproximando-se do velho contrato (civil) de sociedade". Manual de direito das sociedades, cit., p. 26.

${ }^{37}$ Nesse sentido, o contrato emerge como grande instrumento utilizado e reutilizado pela prática para atender ao direito societário (cf. GÉrAldine GoffauX-CALlebaut: "[1]'utilisation du contrat comme instrument d'adaptation du droit des sociétés aux besoins des entreprises et des associés est un phénomène qui trouve sa source dans une pratique. A cette adaptation, les practiciens ont utilisé, voire détourné, des instruments juridiques au titre desquels se trouve essencielement le contrat" Du contrat en droit des sociétés, cit., p. 16). Sobre a contribuição da prática na formação do direito comercial, cf. JEAN PAILlUSSEAU, L'enrichissement du droit et de la pratique professionnelle (un témoignage), in AAVV, Le droit de l'entreprise dans ses relations externes à la fin du $X X^{e}$ siècle: mélanges en l'honneur de Claude Champaud, Paris, Dalloz, pp. 483-506; AAVV, Travaux de l'association Henri Capitant des amis de la culture juridique française - Le rôle de la pratique das la formation $d u$ droit, t. XXXIV, Paris, Economica, 1983; PAULA A. FORGIONI, Interpretação dos negócios empresariais, in, WANDERLEY FERNANDES (coord.), Fundamentos e princípios dos contratos empresariais, São Paulo, Saraiva, 2007, pp. 97- 
A segunda refere-se à compreensão do direito societário como um dos instrumentos mais importantes de formatação do mercado pelo Direito ${ }^{39}$. Regulando a estrutura e funcionamento das sociedades, o direito societário acaba por modelar o mercado que lhes serve de cenário ${ }^{40}$.

Mas há um aspecto do direito societário que é pouco explorado e se demonstra fundamental para o raciocínio que se pretende desenvolver nesta tese: trata-se de uma disciplina voltada, também, à regulação e à tutela do relacionamento societário que os sócios erigem (ou relação societária, "gesellschaftliche Verhältnis" na terminologia alemã) e não apenas da organização societária ("Verband") decorrente de sua associação e sua problemática peculiar ${ }^{41}-{ }^{42}$.

107 e RDM 130, pp. 7-38. Cf., ainda, a posição de LAURENT CONVERT sobre a perspectiva francesa, no sentido de que, naquele país, "a lei está em toda parte" e, assim, deixa-se pouco espaço para a atuação dos agentes ("La loi est partout! Elle ne laisse que des facultes de choix minimes aux praticiens". L'impératif et le supplétif dans le droit des sociétés. Étude de droit comparé Angleterre - Espagne - France. Paris. LGDJ, 2003, p. 209).

38 Ainda com Menezes Cordeiro: "Progressivamente, diversos aspectos, pelos problemas que suscitaram, obtiveram desenvolvimentos mais elevados. Com o tempo e sempre sob as mais variadas contingências, foi possível proceder a generalizações e descobrir princípios (...) A origem fragmentária do Direito das sociedades não é inóqua. Tem consequências efectivas, que ainda hoje se fazem sentir. Apenas a consideração da evolução históricodogmática permite apreender a fenomenologia apontada. (Manual ..., cit., p. 46-47).

39 Sobre formatação do mercado pelo Direito, cf. PAUla A. Forgioni, A evolução do direito comercial brasileiro: da mercancia ao mercado, São Paulo, RT, 2009, pp. 187-241; e IRTi NATAlino, Teoria generale del diritto e problema del mercato, in L'ordine giuridico del mercato, $3^{a}$ ed., Roma, Laterza, 2004, pp. 57-95.

${ }^{40}$ Isso sem falar na temática própria do direito do mercado de capitais, especialização do direito societário.

${ }^{41}$ Esse aspecto será aprofundado no Capítulo 4. De antemão, convém compartilhar a lição de Menezes Cordeiro sobre a inserção das relações entre sócios no campo do direito societário: "[o] moderno Direito das sociedades transcende o limiar bidimensional dos exclusivos relacionamentos sócio/sociedade: há, ainda, ligações diretas entre os próprios sócios. Patentes no caso dos acordos parassociais, tais ligações ocorrem, ainda, instrumentalmente, em vários planos. Além disso, cumpre recordar os deveres de lealdade, que a todos unem" (Manual..., cit., 514).

${ }^{42}$ O raciocínio é seguido por DALMARTello ao examinar o tema das relações internas à sociedade, cuja lição - por sua relevância para os argumentos ora tratados - vale transcrever integralmente, vertendo-a para o português: "o direito moderno distingue no fenômeno associativo uma ordem dúplice de manifestações: de um lado, o processo jurídico através do qual a pluralidade dos sócios e de seus aportes patrimoniais se reduz à 
Somente tendo por base essa relação jurídica fundamental - que se reflete em diversos instrumentos jurídicos - é que a discussão sobre a contratualização do direito societário e a utilização de pactos parassociais pode ser realizada, pois é com vistas à construção desse relacionamento societário que as partes se aproximam e celebram pactos parassociais, dando respaldo a seus interesses comuns.

Nesse passo cabe esclarecer que a personalização do relacionamento societário ocorre mais intensa e tipicamente nas sociedades em que o intuitus personae é relevante, demandando a utilização de instrumentos como os acordos parassociais ${ }^{43}$. Portanto, a ênfase do estudo ora realizado não recai sobre acordos de acionistas celebrados em companhias abertas ${ }^{44}$.

unidade pessoal e patrimonial do ente associativo; de outro a vida de relação do entre associativo, como individualidade operante no mundo jurídico perante outros suheitos. Não se trata de duas distintas: de um período de formação, que se sucede por um período de vida ou de ação. Mesmo quando o ente é constituído e persegue no comércio jurídico as finalidades que lhe foram assinadas, atua e se desenvolve, através de uma contínua rede de relações entre os consócios e entre esses e o ente associativo, a obra de consolidação da unidade corporativa frente os indivíduos que concorrem para formá-la: verifica-se constante a ação de uma força centrípetaque assegura a coesão e a estabilidade do inteiro ente coletivo. Trata-se mais, portanto, de dois lados ou de dois aspectos do fenômeno associativo. Metaforicamente, mas realisticamente, a comum observação qualificacomo interna e externa a dupla face do fenômeno. Delineia, quase, ao redor da sociedade um limite (a 'cerchia sociale') para colocar-lhe dentro as relações da primeira categoria; fora aquelas da segunda" (I rapporti giuridici interni nelle società commerciali, Milano, Giuffrè, 1937, p. 9. Grifou-se).

43 Géraldine GofFAuX-CAllebaut anota que o intuitus personae seria o elemento fundamental para a utilização de contratos nas relações societárias ao permitir estabilidade aos associados ("l'intuitus personae intervient comme mobile de l'utilisation du contrat en tant qu'instrument de stabilité par les associés mus par ce sentiment". Du contrat..., cit. p. $13)$.

${ }^{44}$ Sobre essa questão também esclarecem GRAHAM STEDMAN E JANET Jones que o número de sócios torena o uso de "shareholders agreements" impraticável. ("[s]hareholders" agreements are predominatly made between the members of private companies; not least because public companies commonly have large memberships, thus making the use of such agreements impractical" Shareholders'Agreements, London, Sweet\&Maxwell, 1998, 3a. Edição, p. 1). FABIO KONDER COMPARATO aponta a utilização de pactos parassociais como característica da "sociedade anônima de pessoas" (Restrições à circulação de ações em companhia fechada: nova et vetera, in Novos Ensaios e Pareceres de Direito Empresarial, Rio, Forense, 1981, p. 34-35). 


\section{Contratualização do direito societário}

Em que pesem essas considerações, as relações societárias têm sido disciplinadas pelo legislador, tradicional e fundamentalmente, enfocando-se a existência de um estatuto ${ }^{45}$ ou contrato social. É ele que, fixando a estrutura da sociedade e a forma de sua atuação junto a terceiros, seria a "lei entre as partes" ${ }^{46}$ daquela sociedade e o parâmetro de interação com os demais agentes perante os quais atua ${ }^{47}$.

Cuidou-se, então, de definir legalmente conteúdos mínimos aos estatutos, tendo em vista não apenas relações internas entre sócios ${ }^{48}$ e sociedade, mas também - e sobretudo - externas. Com o estatuto e a sua necessária publicidade, seriam fornecidas aos demais agentes do mercado informações sobre a disciplina daquela sociedade, como o tipo adotado, a responsabilidade dos sócios, os poderes e competências na gestão e os limites da vinculação da sociedade em obrigações contraídas em seu nome ${ }^{49}$.

\footnotetext{
45 Neste trabalho utilizar-se-á a expressão “estatuto social” em homenagem à sua larga difusão na prática societária, em que pese haver quem reserve o termo "estatuto" para o conjunto de regras voltadas a um assunto específico como em "estatuto da terra", "estatuto do idoso", "estatuto do estrangeiro", "estatuto da criança e do adolescente", "estatuto da mulher casada", entre outros, adotando "estatutos sociais", no plural, para o caso de regramento de sociedade ou associação. O dicionário Aulete autoriza o uso no singular: (es.ta.tu.to)sm. 1. Jur. Lei orgânica que estabelece os princípios de funcionamento de uma instituição, empresa, entidade, associação etc., ou de um setor, segmento etc. (estatuto do clube, estatuto previdenciário); regulamento; regimento 2. P.ext. Regulamento ou código com significado e valor de lei ou de norma: estatuto da criança e do adolescente.

${ }^{46}$ Sobre a expressão informa ORLANDo Gomes que "o contrato tem sobre os contratantes realmente força obrigatória a tal ponto que se tornou axiomática a declaração de que faz lei entre as partes" (Transformações Gerais do Direito das Obrigações, RT, São Paulo, 1980, p.77).

47 É comum o paralelo traçado entre a organização da companhia e a organização do Estado. Por todos, cf. Herbert Wiedemann, Gesellschaftsrecht, vol. I, München, Beck, 1980 , p. 18.

48 Para a perspectiva interna à sociedade, fundamental a clássica obra de ARTURO DALMARTELLO, I rapporti giuridici interni nelle società commerciali, já citada.

${ }^{49}$ Sobre o papel do estatuto social, cf. Diego CoRAPI, Gli statuti delle societá per azioni, Milano, Giuffrè, 1971, p. 103 e ss.
} 
Porém foram surgindo necessidades práticas - ligadas à sempre mais sofisticada configuração do relacionamento societário entre as partes - para as quais o estatuto, com sua função organizativa do exercício coletivo da atividade empresarial, ou mesmo a lei, abstrata e geral, não apresentaram resposta ${ }^{50}$.

A infinita possibilidade de criação de negócios jurídicos com base em cada vez mais diversas e especializadas operações econômicas passou a impactar cada vez mais o relacionamento entre sócios e conduziu os agentes econômicos, pois, a estipular os mais variados ajustes sobre ele incidentes, no exercício de sua autonomia contratual, resultando em sofisticada engenharia negocial ${ }^{51^{-52}}$.

\footnotetext{
${ }^{50}$ LAURent Convert anota, sobre as diferentes funções dos estatutos sociais frente as convenções parassociais, que as últimas permetem adaptação mais facilitada dos interesses dos diversos membros da sociedade ou grupos de membros, ao passo que "o formalismo ligado a tomada de decisão coletiva incita os sócios a "se entenderem diretamente" ("[1]a réglementation stricte des statuts et le formalisme qui entoure la prise de décision collective incite en conséquence les associés à 's'entendre directement'. Les pactes permettent en outre de moduler la teneur des relations entre les différents membres de la structure ou entre groupes de membres, ce que le recours aux statuts ne permet de faire que de manière collective, brute et limitée (création de catégories d'actions, vote sure l'intéressement de chacun, variations des droits de vote, etc). Les conventions favorisent l'adaptation". L'impératif... cit., pp. 496-97).

51 Tullio Ascarelli refere-se ao fenômeno ao constatar, já em 1955, a "maggiore importanza che, nello stesso lavoro dell'avvocato, assume la c.d. assistenza contrattuale con un'attività che a volte ricorda piuttosto quella dell' 'ingegnere' intesa a creare 'macchine' giuridiche, che non quella del 'patrono' nel cozzo di opposte interpretazioni" (Norma giuridica e realtà sociale, in Problemi giuridici, Vol. 1, Milano, Giuffrè, 1959, p. 110). Interessante notar, nesse sentido, que o prestigiado periódico francês Bulletin Joly Sociétés já contém seção designada ingégnierie financiére para tratar justamente de problemas afeitos a essa realidade. Jean PaIllusseau observa que a ideia de "engenharia jurídica" evoca a idéia de operação complexa, mesmo que o termo seja um "barbarismo" ("[1]a recherche de ces multiples techniques et solutions évoquent l'idée "d'ingénierie" juridique, si ce n'est celle "d'ingénierie juridico-fiscalo-financière", barbarisme, certes, mais Ô combien envocateur! Le résultat d'ensemble, surtout s'il est complexe (plusieurs sociétés, par exemple sont constituées avec de multiples relations entre elles), évoque l'idée de 'montage' voire de 'montage complexe'". L'Enrichissement du droit et de la théorie juridique par la pratique professionelle (um témoignage) in Le Droit de l'Entreprise dans ses relations externes à la fin $d u X X^{e}$ Siecle - Mélages em l'honneur de Claude Champaud, Paris, Dalloz, 1997, p.504).

${ }^{52}$ No mesmo sentido, MENEzes Cordeiro anota que “[t]anto na lei como na doutrina, cada negócio contratual surge como um espaço insular e bem delimitado; ele apresenta-se como uma figura autônoma e inteiramente desligada, quer em termos de celebração, quer no regime, de quaisquer outros negócios circundantes. O tráfego comercial faculta um cenário
} 
De certo modo, a própria gênese da sociedade torna-se complexa, no sentido de que, para atender a função econômica expressa na associação entre as partes interessadas em desenvolver atividade econômica conjunta, um nodo negocial, complexo e único, mais frequentemente passa a ser criado.

Conforme tem sido apontado na doutrina européia ${ }^{53}$, sobretudo francesa, a chamada contratualização do direito societário (contractualisation du droit des sociétés) emerge, assim, para complementar e enriquecer a disciplina legal ${ }^{54}$, tanto pela introdução de cláusulas estatutárias especificamente talhadas, como, especialmente, pela celebração de contratos que, no jargão internacional, são genericamente designados como "shareholders" agreements" ${ }^{55}$.

efectivo bastante diferente. Muitas vezes os contratos encadeiam-se, uns nos outros, de tal modo que surge toda uma série de interacções relevantes para o regime aplicável" (Manual de direito comercial, Vol. I, 2a ed., Coimbra, Almedina, 2007, pp. 366-67, grifamos). Sobre a estruturação de um arcabouço contratual complexo para dar vida a operações econômicas singulares, fundamental a tese de JEAN-PHILIPPE DOM, Les montages em droit des sociétés, Paris, Joly, 1998. V. ainda, para contratos coligados no direito brasileiro, Francisco Marino Filho, Contratos coligados, São Paulo, Saraiva, 2009.

${ }^{53}$ No que tange à autonomia contratual no direito societário, referência especial deve ser feita a MARCUS LUTTER e HERBERT WIEDEMANN (orgs.), Gestaltungsfreiheit im Gesellschaftsrecht. Deutschland, Europa und USA. 11. ZGR-Symposium "25 Jahre ZGR", Berlin, Walter de Gruyer, 1998; SophiE SCHILler, Les limites de la liberté contractuelle en droit des sociétés: les connexions radicales, Paris, LGDJ, 2002; DoMENICO GIORDANO, Le limitazioni all'autonomia privata nelle società di capitali, Milano, Giuffrè, 2006; DANIEL ESPINA, La autonomía privada en las sociedades de capital: principios configuradores y teoría general, Madrid, Marcial Pons, 2003.

${ }^{54}$ No dizer de Yves GUYON, "[1]e droit des sociétés est ainsi assoupli, infléchi et enrichi par des contrats conclus par la société ou par les associés, entre eux ou avec des tiers" (Les sociétés... cit. p. 9).

${ }^{55}$ As denominações dos contratos que podem ser reconduzidos a esse termo genérico são as mais diversas, em função das peculiaridades de cada ordenamento. Vários autores trazem anotações a este respeito. Em resumo, LUIGI FARENGA enuncia, por exemplo, que "as razões do aparente desinteresse por parte do legislador e da doutrina para os contratos em exame são obtidas essencialmente na extrema heterogeneidade do fenômeno que se quer designar com a expressão 'contratos parassociais'. Tal expressão tanto é feliz na sua formulação e, assim, de imediata apreensão, sobretudo, pelos práticos quanto esconde em suas costas uma realidade em que se encontram fattispecie dificilmente reconduzíveis a um fenômeno homogêneo e, portanto, inidônea a representar uma categoria jurídica (in verbis: "le ragioni dell'apparente disinteresse da parte del legislatore e della dottrina per i contratti in esame vanno ricercate essenzialmente nella estrema eterogeneità del fenomeno che si vuole richiamare con l'espressione 'contratti parasociali'. Tale espressione, tanto è felice nella sua formulazione e, quindi, di immediata apprensione soprattutto da parte dei 


\section{- 2.Contratos parassociais: função e noção.}

$\mathrm{Na}$ maioria das vezes, esses "shareholders" agreements" são contratos que, de maneira mais ou menos intensa, dizem respeito à relação societária estabelecida entre os pactuantes, sem se confundir, entretanto, com os estatutos sociais. A doutrina francesa, por essa razão, vale-se do termo extraestatutário (extra-statutaire) para a eles se referir, enquanto a doutrina italiana mantém a expressão parassocial (parasociale) cunhada por Giorgio $\mathrm{OPPO}^{56}$.

Diversamente dos estatutos, cuja função primordial é determinar a estrutura da companhia e as regras de sua vinculação perante terceiros (função organizativa, portanto), os contratos a que nos referimos têm normalmente por objetivo regular o exercício de direitos dos sócios, fundados em sua participação na sociedade.

Com essa contratação, as partes buscam disciplinar interesses e situações não compreendidos no estatuto social, conferir a regras societárias

pratici, tanto nasconde alle sue spalle una realtà in cui si riscontrano fattispecie difficilmente riconducibili ad un fenomeno omogeneo e, pertanto, inidonea a rappresentare una categoria giuridica” (I contratti parasociali, Milano, Giuffrè, 1987, pp. 3-4). Considerações semelhantes são feitas por JEAN-JACQUES DAIGRE e MoniQue SENTILLESDupont, Pactes d'actionnaires, Paris, Joly, 1995 p. 3; MÁRIO Leite SAntos, Contratos parassociais e acordos de voto nas sociedades anónimas, Lisboa, Cosmo, 1996, pp. 14-15; GiUseppe Santoni, Patti parasociali, Napoli, Jovene, 1985, p. 12 e ss.; JOUSSEN, Gesellschafterabsprachen... cit. p. 5; e LAURRIEU ("Or, toute la difficulté consiste à dresser une typologie de ces accords particuliers. Dans l'univers 'bariolé', pour ne pas dire 'baroque' des pactes extra-statutaires, la grande diversité des situations qu'ils ont pour objet de traiter doit être soulignée, cette diversité ne connaissant d'autre limite que celle tenant à l'imagination de leurs acteurs". L'interprétation..., cit, p. 699).

${ }^{56}$ No alemão utiliza-se mais comumente Nebenabreden, ou seja, convenções laterais. Para convenções de voto, tem-se Stimmverbindung. Cumpre notar que a própria diferença terminológica denota a diversa perspectiva que se tem desses contratos, já que no termo shareholders' agreement a ênfase é dada ao fato de o ajuste ser o acordo dos sócios (= aquilo que definiram para seu relacionamento). Nos direitos continentais, as expressões usadas (parasociale; extra-estatutaire; Nebenabrede) apontam perfil mais dogmático, voltado à relação entre esse contrato e o estatuto/contrato social. Como se verá no decorrer da explanação, essa escolha se reflete na produção acadêmica e na própria compreensão do fenômeno, já que quase não se encontram obras - exceto algumas contribuições mais recentes - que avancem a partir do exame da funcionalidade dos contratos no fenômeno societário globalmente considerado, superando, assim, a perspectiva "contratualista" inaugurada por OPPO. 
sentido mais específico no que tange a seu relacionamento, ou mesmo contratar quais serão as bases pelas quais determinada sociedade será constituída e governada, peculiaridades do negócio idealizado e seu detalhamento ${ }^{57}$.

Tenciona-se, ao final, personalizar o relacionamento societário existente entre os signatários e/ou construi-lo conforme suas particulares necessidades e objetivos comuns.

Frequentemente aponta-se como motivos para a celebração desses contratos em sede apartada do estatuto social: (i) o fato de que eles o antecedem, como nos contratos de investimento, associação ou de joint venture; (ii) o fato de não necessariamente envolverem todos os acionistas de uma companhia, mas apenas aqueles que entre si desejam compor interesses; Todavia, é cada vez mais comum que sejam celebrados por todos os sócios, trazendo a identificação completa entre as partes do contrato de sociedade (iii) a especificidade do interesse regulado, que pode afetar diretamente apenas a esfera jurídica dos contratantes - e não da companhia, de terceiros ${ }^{58}$ ou ainda de eventuais outros sócios não signatários; e (iv) a menor publicidade a que são submetidos quando comparados com os atos constitutivos das sociedades, que são levados a registro no órgão competente ${ }^{59}$.

Noticia-se que, por sua função de personalizar e detalhar o relacionamento societário entre as partes, os campos mais característicos da

\footnotetext{
57 Quanto ao momento de celebração GiUseppe SANTONi esclarece que “os contratos parassociais permitem aos sócios criar um vínculo puramente obrigatório entre eles, o qual pode se referir qualquer das fases que caracterizam a vida da sociedade: tanto ao desenvolvimento da atividade social, quanto a seu início e cessação" ("[i] contratti parasociali consentono ai soci di creare un vincolo puramente obbligatorio fra di loro, il quale puó riferirsi ad una qualunque delle fasi che caratterizzano la vita della società: tanto allo svolgimento dell'attività sociale, quanto all'inizio e alla cessazione di questa". (Patti parasociali, cit., p. 4). No mesmo sentido, cf. Oppo, Contratti parasociali, cit., p. 84.

58 Em alguns casos, porém, a companhia é reflexamente afetada pela contratação. No direito brasileiro há mesmo a sua expressa vinculação em se tratando de determinadas ocorrências de acordos de acionistas.
}

${ }^{59}$ Cf. Laurent Convert, L'imperatif... cit. pp. 495/501. 
utilização de shareholders' agreements são as sociedades formadas em virtude de acordos de joint venture, aquelas em que se verifica intenso caráter intuitu personae, e as companhias em que há o ingresso de fundos de private equity ${ }^{60}$.

Em todos os casos, os shareholders' agreements permitem que o relacionamento societário seja especificamente modelado, ajustado aos interesses das partes ${ }^{61}$ por disciplinarem pormenores que não caberia aos estatutos sociais regrar e fazem com que, no estado de sócio de cada partícipe do ajuste, incluam-se os deveres e direitos previstos parassocialmente ${ }^{62}$.

Com relação à suposta relação de hierarquia entre estatuto social e contrato extraestatutário ou parassocial ${ }^{63}$, observa-se, com referência aos acordos de associação, investimento e joint venture que ela é frequentemente invertida, ostentando o contrato parassocial - firmado por todos os sócios ${ }^{64}$

${ }^{60}$ Cf. Jean-Jacques Daigre e Monique Sentilles-Dupont, Pactes d'Actionnaires. cit. pp. 2-3 e STEDMAN E Jones, Shareholders'Agreements. cit., p. 1. Como já apontado, as considerações do presente trabalho não abarcam o universo peculiar das companhias abertas.

${ }^{61} \mathrm{Na}$ expressão de PEgGy LARrieu, "[1] eur positionnement en memarge des statuts sociaux démontre d'ailleurs l'intention des signataires de les tailler à la mesure de leurs intérêts". (L'interprétation..., cit. p. 698).

${ }^{62}$ Cf. autorizada opinião de Menezes Cordeiro, Manual..., cit., p. 507. Mais adiante, no Capítulo 4, esse aspecto será aprofundado em vista de o "estado de sócio" ser elemento fundamental para interpretação dos pactos parassociais, sob a ótica ora proposta.

${ }^{63}$ Sobre o tema, cabe agradecer as lúcidas observações que o Prof. José ALEXANDRE TAVARES Guerreiro no curso de discussões na fase inicial de redação do presente trabalho, em abril de 2010.

64 GUYON evidencia a dificuldade de separação entre estatutos e pactos parassociais, quando há identidade entre os signatários, por se tratar do mesmo objetivo e do campo de atuação ("[b]ien que formellement distincts des statuts, les pactes en sont difficilmente divisibles lorsqu'ils ont été conclus entre tous les associés, car les uns et les autres tendent à la réalization d'un même objectif et ont le même domaine d'application" Les sociétés..., cit. p. 310). O alvo comum de ambos os instrumentos jurídicos é, como se tem ressaltado, o relacionamento societário existente entre os pactuantes. O autor pondera, contudo, que "o princípio parece ser o da separação entre os instrumentos, já que não faria sentido recorrer-se a dois instrumentos quando um só pudesse cumprir a mesma função, mas a unicidade se impõe quando o pacto tem caráter fundamental na relação societária" ("le principe semble être l'indépendence du pacte e des statuts, car on ne conçoit pas pourquoi les associés ont eu recours à deux actes s'ils entendainent les traiter comme um tout. Cepedant l'indivisibilité s'impose si le pacte a un caractére fondamental parce que qu'il accorde les droits individuels aux associés et si ceux-ci sont tous parties à ce pacte" (Idem, p. 311). 
para a gênese do relacionamento societário entre os pactuantes e/ou as características cruciais desse relacionamento - muito mais relevância para o que realmente pretendem as partes com relação àquele negócio que o estatuto social $^{65}$, com função organizativa da pessoa jurídica que serve de instrumento para que os interesses dos contratantes sejam atendidos ${ }^{66}{ }_{-}^{67}$.

Essa percepção, todavia, raramente é alvo de comentários ou aprofundamentos doutrinários ${ }^{68}$. Em outras palavras, não se “alargou” o campo de visão a respeito do fenômeno societário, de modo a nele incluir ajustes entre sócios (especialmente entre todos os sócios) que não equivalem ao estatuto social, mas que determinam as reais condições da relação societária

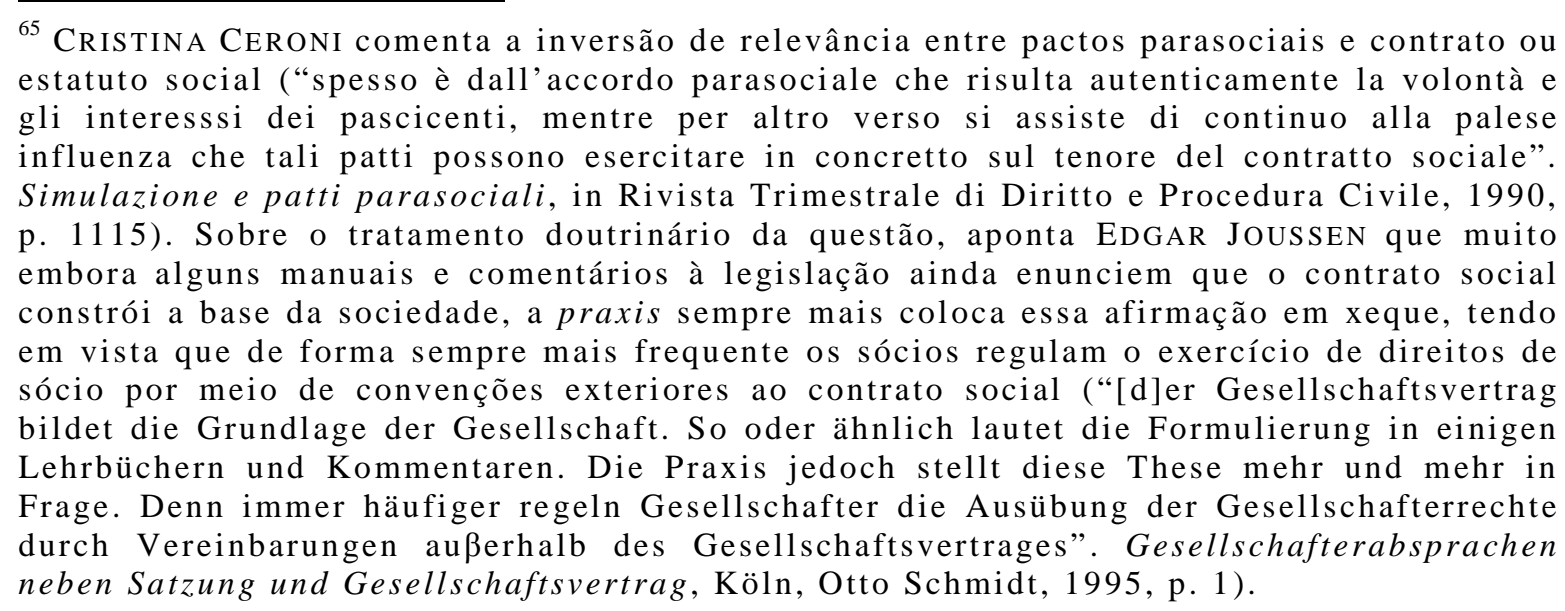
66 Outro aspecto relevante e pouco explorado, conforme asseverou, em entrevista de 16/04/2010, o Prof. José Alexandre TAVAres Guerreiro é o fato de que, uma vez admitida independência do vínculo obrigacional parassocialmente constituído pelas partes, ele pode, a depender da natureza da obrigação contratada, perdurar mesmo se um dos signatários não mais é sócio ou ainda que a sociedade seja dissolvida, decorrência do princípio da obrigatoriedade dos contratos. Assim, se no pacto um acionista obriga-se a determinada conduta frente aos demais e não a cumpre, sua responsabilidade persiste ainda que, no meio tempo, a sociedade não mais exista (ou mesmo não tenha sido constituída, apesar das previsões contratuais).

${ }^{67}$ Oppo já refletia a respeito dessa hipótese: “oltre a tale dipendenza puó intercorrere fra $\mathrm{i}$ due negozi un nesso di dipendenza reciproca quando il negozio acessorio assume veste essenziale in raporto all'intento perseguito in concreto, si che non si sarebbe voluto il contratto sociale senza il negozio parasociale”. (Contratti parasociali cit., p. 82).

${ }^{68}$ MANUEl CARNEIRO DA FRADA aponta algumas considerações nesse sentido em Acordos parassociais "omnilaterais": um novo caso de "desconsideração" da personalidade jurídica?, in Direito das Sociedades em Revista 2, out. 2009, pp. 97-135. 
existente (i.e., e não apenas os termos da estruturação da companhia por meio do estatuto $)^{69}$.

Nessa linha, ousa-se ora dizer que "contratar sociedade", no contexto peculiar em exame, não pode mais ser, necessariamente, sinônimo da celebração do contrato social (contrato de sociedade) e muito menos da elaboração do estatuto e sua aprovação assemblear. Na grande maioria dos casos, na atualidade, a causa econômica do fenômeno societário (i.e. reunião de esforços para consecução de escopo comum) não é eficazmente atingida ou refletida - apenas nesses instrumentos, muito embora ainda existam sociedades calcadas em contextos econômicos e relacionamentos societários mais simples, com seus contornos traçados pelo estatuto ou contrato social, bem como pelas disposições legais aplicáveis ao tipo societário em questão.

No contexto negocial das últimas décadas, ao contratar sociedade (criando sociedade nova ou ingressando em pré-existente) as partes mais frequentemente convencionam entre si um plexo de ajustes e contratos, necessários ao atingimento de seus interesses e regulação de sua conduta, tendo em vista aquele relacionamento societário $^{70}$.

\footnotetext{
69 SAntoni confirma o raciocínio ao explicar que “o desenvolvimento das relações jurídicas que nascem de um contrato de sociedade é frequentemente, na prática, influenciado por acordos e pactuações estipulados por uma parte ou pela totalidade dos sócios, entre eles, com a própria sociedade ou mesmo com terceiros" ("[1]o svolgimento dei rapporti giuridici che nascono da un contratto di societá è spesso, nella pratica, influenzato da accordi e pattuizioni stipulati da una parte o dalla totalità dei soci, tra di loro, o con la stessa società o addirittura con terzi" Patti parasociali, cit., p.1). Pela complexidade teórica adicional que ostentam, não serão alvo da presente tese os contratos firmados entre sócios e sociedade ou mesmo entre sócios e terceiros (e.g diretores, credores, etc) que, não obstante, também impactam o relacionamento societário.

70 Giorgio OpPo, 45 anos após introduzir o termo "contratos parassociais", na doutrina italiana, reflete a respeito do fenômeno que acima se apontou, constatando que "afirmouse, seja na nossa literatura que na literatura estrangeira que não existiria sociedade de um certo porte em torno da qual não se cruzem acordos deste tipo, com a função de adequar o esquema societário aos interesses concretos das partes e assim, de algum modo, de "personalizar' a disciplina do instituto" ("[s]i è affermato, sia nella nostra letteratura che nella letterattura straniera che non vi sarebbe società di un qualche rilievo intorno alla quale non si intreccino accordi di questo tipo, con la funzione di adeguare lo schema societario agli interessi concreti delle parti e quindi, in qualche modo, di 'personalizzare' la disciplina dell'istituto"). Le convenzioni parasociali tra diritto delle obbligazioni e diritto delle societá, in Rivista di Diritto Civile, 6, 1987, p. 518. No mesmo sentido,
} 
Com referência a esse relacionamento, o estatuto e a pessoa jurídica da sociedade, mostram-se, afinal, como peça da engrenagem montada pelas $\operatorname{partes}^{71}$.

Por consequência, não se pode desconsiderar os fatores acima apontados como elementos de atração da lógica societária - e não meramente contratual - a esses ajustes em que verdadeiramente se funda grande parte dos relacionamentos societários nos dias de hoje.

\section{Oppo como ponto de partida}

Entre os esforços doutrinários realizados na tentativa de descrever as modalidades de contratos entre sócios, foi fundamental - ao menos para os países ligados à tradição romano-germânica - a obra de Giorgio OpPo, Contratti parasociali, publicada em 1942.

Desde então, a expressão contrato (ou pacto) parassocial (patti parasociali, pactes de associés) foi recepcionada em vários ordenamentos jurídicos, sendo constante na doutrina, em que pese se referir a uma miríade de situações diversas.

Para OPPO, em síntese, contratos parassociais seriam aqueles contratos distintos do contrato de sociedade, mas que com ele guardam uma coligação (collegamento). Contudo, não obstante essa coligação, o que se regula no contrato parassocial teria efeito apenas obrigacional entre os pactuantes, não

\footnotetext{
afirma SANTONi que “a sua difusão na praxe societária é indiscutível. Com ênfase, pode-se afirmar que nenhuma sociedade poderia funcionar com regularidade sem a intervenção de tais tratativas e componentes negociais realizados pelos sócios fora dos esquemas societários, com relação à realização da atividade comum" ("[1]a loro diffusione nell'ambito della prassi societaria è indiscussa. Con enfasi, può affermarsi che nessuna società potrebbe funzionare con regolarità senza l'intervento di tali trattative e componimenti negoziali raggiunti dai soci al di fuori degli schemi societari, in merito alla realizzazione dell'attività comune". Patti parasociali, cit., p. 2).

71 É claro que não se cogita dizer que a sociedade, uma vez criada, não tenha seus interesses próprios ou que outros interesses não acorram a ela durante a sua existência. A perspectiva que se toma, aqui, é a das partes que se relacionam em sociedade e modo como estatuto ou contrato parassocial impactam esse relacionamento.
} 
vinculando a companhia. Ou seja, as disposições contratuais seriam inoponíveis, a menos que não se trate, por exemplo, de situações em que a totalidade dos sócios é também signatária do acordo ${ }^{72}$.

Sob a ótica do direito civil, considerando a dogmática contratual da época, OpPo procurou analisar os contratos que se multiplicavam na prática e determinar o sentido da sua acessoriedade com o contrato ou estatuto social ${ }^{73}$, além de avaliar se deveriam "sujeitar-se à peculiar disciplina de forma e substância que é própria do contrato social" 74 .

Apresentou classificação desses mesmos contratos adotando como critério a sua capacidade de influir ou não na organização elou funcionamento da sociedade, não os examinando sob a perspectiva do negócio que as partes buscavam concretizar. Nesse sentido, os contratos parassociais poderiam ser divididos $\mathrm{em}^{75}$ :

a) contratos que podem restringir seus efeitos e sua ação somente aos sócios contratantes e ter eventualmente, para a sociedade e outros sócios uma repercussão de mero fato, nem favorável, nem desfavorável ${ }^{76}$.

\footnotetext{
${ }^{72}$ In verbis: "in ogni caso il collegamento del contratto accessorio col contratto sociale non è opponibile fuori dei rapporti immediati con la controparte del patto accessorio e cioè non è opponibile agli altri soci, alla società e ai terzi. Ciò significa che una ripercussione reale delle vicende del negozio accessorio sulla posizione delle parti nella società è in principio esclusa: una tale ripercusione potrà aversi solo in qualche ipotesi e precisamente in quanto tutti i soci siano al tempo stesso soggeti del rapporto accessorio" (Contratti parasociali cit., p. 82).

${ }^{73}$ Para boa análise da posição de OPPo do ponto de vista da coligação negocial, cf. a obra de Francisco Marino, Contratos coligados, cit. pp. 57-60.

${ }^{74}$ Contratti..., cit., p. 40.

${ }^{75}$ Essa classificação é repetida incansavelmente pelos autores que sucederam Oppo na Itália e no Brasil, sem que dela se extraia mais qualquer resultado teórico para o exame dos pactos parassociais no direito societário evidenciando-se, ao contrário, características de um ou outro tipo de pacto parassocial na dogmática contratual.

76 "Possono restringere i loro effetti e la loro azione ai soli soci stipulanti ed avere eventualmente per la società (e gli altri soci) una ripercussione di mero fatto, nè favorevole, nè sfavorevole" (Contratti..., cit., p. 7.)
} 
b) contratos que podem ser destinados a gerar para a sociedade vantagens particulares a cargo dos sócios e que não são previstas no contrato social, para evitar publicidade ${ }^{77}$.

c) contratos que podem incidir diretamente sobre a sociedade ou serem destinados a influir sobre sua vida e sobre a determinação de sua ação, ou mesmo invadam juridicamente a esfera de direitos da sociedade e a competência de seus órgãos ${ }^{78}$.

Importante notar, pois, que OPPO entendia relevantes como contratos parassociais, para os fins de sua investigação, apenas os contratos agrupados em B) e C). Ou seja, o estudo da acessoriedade e seus efeitos seria necessário ou mesmo oportuno apenas quando esses contratos incidissem de qualquer modo sobre a vida social. Por consequência, os contratos previstos no grupo A) - principais alvos da presente análise - não foram considerados por OPPO em seu estudo, justamente pelo corte metodológico que nele se pode identificar e não - como hoje podemos avaliar - porque não sejam alvos da disciplina societária.

Ainda em decorrência dos estudos de OPPO, assim, tornou-se pacificado na doutrina dos diversos ordenamentos o entendimento segundo o qual esses contratos, ao produzirem efeitos apenas entre as partes, deveriam ser regidos pelo direito comum das obrigações, e não pelo direito societário (i.e., não se aplicariam as regras relativas ao contrato de sociedade).

Como acima se referiu, essa visão não atende totalmente ao que a realidade negocial tem apresentado desde que a obra de Oppo foi escrita. Por essa razão, tendo em vista as limitações deste trabalho e o enfoque que se pretende conferir sobre a funcionalidade dos contratos parassociais para o relacionamento societário e para que a intenção comum das partes na

\footnotetext{
77 "Possono essere diretti a procurare alla società vantaggi particolari a carico dei soci (e che non vengono previsti nel contratto sociale per evitare la pubblicità)” (Idem, p.9).

78 "Possono incidere direttamente sulla società o in quanto siano diretti ad influire sulla sua vita e sulla determinazione della sua azione o in quanto addirittura invadano giuridicamente la sfera di diritti della società e la competenza dei suoi organi sostituendo a questi ultimi i singoli soci o la loro somma operanti in veste extrasociale" (Idem, p. 11).
} 
associação seja atingida, não serão aqui aprofundadas as reflexões de OpPo, mais centradas no exame da dogmática contratual ${ }^{79}$.

Pode-se dizer que, em termos gerais, a doutrina italiana posterior à obra de Oppo trilhou o mesmo caminho, avaliando precipuamente a coligação negocial entre contrato social e contrato parassocial, apresentando, por vezes, novas classificações para os contratos parassociais.

Comentando a evolução da doutrina italiana sobre os pactos parassociais, CRISTINA CERONI esclarece que ela se deu precipuamente no sentido de identificar quais os critérios capazes de atribuir aos pactos parassociais significado juridicamente mais apropriado ao sistema normativo, com base em duas linhas conexas: (i) a verificação do tipo de relação entre contrato social e parassocial e (ii) a investigação sobre a possibilidade de reunião das várias modalidades de pactos parassociais em uma única categoria negocial conceitualmente autônoma ${ }^{80}$.

Destaca-se, nesse sentido, as obras de Luigi Farenga ${ }^{81}$ e Giuseppe Santoni $^{82}$, além da coletiva de Franco Bonelli e Piergiusto Jaeger ${ }^{83}$.

\footnotetext{
${ }^{79}$ Partindo da perspectiva da distinção entre contrato social e parasocial, Oppo centra sua análise no exame da natureza da relação entre os contratos e de cada contrato parasocial (Idem, p. 67). Tomando a coligação igualmente existente entre os contratos, resalta a existência de conexão econômica e autonomia jurídica (p. 72), mas rechaça a ideia de um negócio único e complexo que abarque toda a fattispecie, em vista da necessária distinção ("non puó sboccare alla configurazione di um negozio complessivo che assorba l'intera fattispecie" Idem, p. 88). CRISTINA CERONI menciona e igualmente critica a tentativa de criação de um "supernegócio", seguindo a linha de análise funcional da coligação entre negócios distintos (Simulazione..., cit., p. 1.118)

${ }^{80}$ (Simulazione...., cit., p. 1115). De fato, segundo a autora, a perspectiva dominante nos estudos daquele país é a de pesquisa tipológica relativa aos contratos parassociais ("[i]n questa prospettiva, che è fondamentalmente di ricerca tipologica, lo studio relativo ai patti parasociali si è posto innanzittutto il problema di elaborare quei 'criteri d'individuazione' dei patti medesimi, e questo al fine di rispondere ad un quesito preliminare che riguarda la possibile identificazione di una apposita categoria comprensiva di tutti questi accordi e, su questa base, cogliere e specificare la natura del rapporto esistente tra contratto sociale e patti parasociale". Idem, ibidem). Nota-se, assim, que o tema da interpretação dos contratos parassociais ou mesmo a sua análise do ponto de vista da função que desempenham no relacionamento societário não foram tratados com a ênfase que, ao contrário, a eles se pretende dar neste trabalho.
}

${ }^{81}$ I contratti parasociali, Milano, Giuffrè, 1987 
Em breve síntese, FARENGA classifica os contratos parassociais conforme incidam (exerçam influência) ou não sobre a organização social, designando-os, respectivamente, "contratti parasociali in senso stretto" e "contrati parasociali extrasociali", esses últimos relativos apenas a direitos individuais dos contratantes.

A relevância da distinção estaria em que a disciplina da nulidade, anulabilidade e resolução dos contratos parassociais variaria conforme se tratasse ou não de contrato "associativo" ou "incidente sobre a organização". O autor compara, por exemplo, os cenários de resolução contratual quando se trata de "sindacato di voto" (incidente sobre a organização) e "sindacato di blocco" ("extrasociali").

Além disso, FAREnga sustenta que há graus de autonomia dos diversos contratos parassociais, na medida em que somente com relação aos patti "extrasociali" ela existiria de fato, ao passo que nos contratos parassociais incidentes sobre a organização social, ela seria apenas genética ${ }^{84}$.

Muito embora se possa extrair importantes conclusões dessas análises, elas não tocam o tema da interpretação dos contratos parassociais e sua conformidade com os princípios societários.

Igualmente, não se examina o problema, em regra, sob o ponto de vista do relacionamento societário criado pelas partes, em que mesmo contratos tidos por "extrasociali" (isto é, que não dizem respeito à organização da sociedade) podem ser vistos como inerentes e basilares a esse mesmo

\footnotetext{
${ }^{82}$ Patti parasociali, cit..

${ }^{83}$ Sindacati di voto e sindacati di blocco, Milano, Giuffrè, 1993.

${ }^{84}$ No dizer do autor, "sono invece contratti autonomi quei contratti parasociali che influiscono solo sulle situazioni individuali derivanti dal contratto di società e che pertanto si pongono come un qualcosa di 'esterno' rispetto alla società e sono perciò extrasociali” (I contratti parasociali, cit., p. 225).
} 
relacionamento e, portanto, integradores da disciplina aplicável aos sócios signatários e configuradores de sua conduta enquanto tais ${ }^{85}$.

Seu escopo permanece na verificação da acessoriedade entre contratos, enquanto ora se busca avaliar os contratos parassociais sob o todo complexo em que as partes se inserem para sua associação societária.

GiUseppe SAntoni, por sua vez, classifica os contratos parassociais em pactos "complementari", que são os que geram vantagem à sociedade e têm seu regime aproximado aos dos contratos em favor de terceiro; e pactos "collaterali", seriam aqueles voltados exclusivamente a direitos individuais dos sócios que, no seu entender, não seriam capazes de influenciar a vida da sociedade ${ }^{86}$.

Dentre as contribuições de SANTONI, deve-se sublinhar a acurada análise sobre a confusão interpretativa que frequentemente leva a se dizer algo sobre pactos parassociais que, em verdade, aplica-se apenas aos "sindacati di voto", ignorando-se, assim, toda a série de contratos e pactos que, em tese, não influenciam a sociedade ${ }^{87}{ }_{-}^{88}$.

\footnotetext{
85 Ainda com relação aos contratos parassociais que designa "extrasociali" por não interferir na organização da sociedade, FARENGA se delonga na análise de sua validade, perpassando cada modalidade de contrato dessa natureza e apontando questões específicas que podem apresentar, sem entretando enunciar critérios de interpretação que possam ser usados com vistas a outros contratos parassociais "extrasociali" que porventura ainda não se tenham manisfestado, o que seria fundamental considerando a criatividade e a crescente complexidade das ocasiões em que se desenvolvem (I contratti Parasociali, cit., pp. 373 e ss). Na presente tese, procura-se justamente avaliar e propor critérios interpretativos para os contratos parassociais "extrasociali" (que designamos patrimoniais) baseados na lógica própria que dá suporte ao relacionamento societário e o torna diverso de qualquer outro relacionamento contratual.

${ }^{86}$ Cf. Patti parasociali, cit., p. 144-145; p. 147 e p.223.

${ }^{87}$ In verbis: "Invero, non v'è dubbio che il malinteso interpretativo ora segnalato vada ricondotto all'arbitraria assimilazione dei problemi ermeneutici dei contratti parasociali con quelli, specifici e parziali, degli accordo di voto, con la conseguenza che tutti sono stati generalmente risolti da una consolidata corrente giurisprudenziale in base alla valutazione della conformità dei patti all'interesse sociale (Patti parasociali, cit. p. 20).

${ }^{88}$ Sobre o problema, cf. item 5 desse capítulo, a seguir.
} 
Além disso, SAntoni ensaia um passo na direção da proposta desta tese, ao ressaltar que o tema da definição de critérios interpretativos para os contratos parassociais deveria ser tratado antes mesmo de se avaliar questões sobre validade e eficácia dos pactos, determinando se ela deve realizar-se com base nas normas de direito societário ou recorrendo-se aos princípios gerais dos contratos ${ }^{89}$.

Em que pese essa preocupação, o autor não aprofunda o tema de forma satisfatória, adotando a mesma linha de OPPO e FARENGA de considerar como possível alvo de preocupações societárias apenas o que "incide sobre a sociedade".

Pelo que até o momento já se adiantou, essa perspectiva parece não servir quando se joga luzes ao fato de os pactos parassociais serem peçaschave na disciplina do relacionamento societário, ainda que não gerem qualquer efeito direto sobre a sociedade (= pessoa jurídica).

Em suma, grande parte dos autores que vêm seguindo a tradição italiana inaugurada por OPPO enxergam distinção de negócios (i.e. contrato social/contrato parassocial), ainda que coligados, onde em verdade - e tomando-se a perspectiva do relacionamento erigido entre os contratantes verifica-se unicidade de intenções e de propósitos dos signatários/acionistas. Além disso, seu enfoque é precipuamente voltado ao exame tipológico dos contratos parassociais, o que pouco tem contribuído para que sejam encontradas soluções para as crescentes dificuldades teóricas colhidas da prática $^{90}$.

\footnotetext{
89 “Sorge cosí l'esigenza di chiarire, prima ancora dei quesiti inerenti alla validità e alla efficacia dei contratti parasociali, i criteri di valutazione alla cui stregua quei contratti debbano essere esaminati, e, in particolare, se l'interpretazione di questi ultimi vada effettuata in base alle norme di diritto societario o invece ricorrendo ai principi generali dettati dal nostro ordinamento per i contratti" (Idem, p. 11).

${ }^{90}$ Mais uma vez, cabe aqui reproduzir a crítica de CRISTINA CERONi de que as soluções cogitadas pela doutrina sobre os pactos parassociais apresentam lacunas pelo seu descompasso com a realidade prática ("le argometazioni a sostegno di ogni soluzione avanzata, trovano quindi una loro giustificazione solamente pensando di affrontare e
} 


\section{A posição de GUYON e sua importância para a tese.}

A doutrina francesa tem se mostrado mais propensa a abarcar, em um mesmo complexo negocial, os variados instrumentos que, ao fim e ao cabo, servem à estruturação da sociedade em seu dúplice aspecto, ou seja, como relacionamento e como organização $o^{91}$.

Nesse contexto, Yves GuYon figura como autor fundamental para o entendimento do fenômeno societário na atualidade, envolvido e sustentado pelas mais variadas manifestações contratuais ${ }^{92}$.

A nota diferenciadora da leitura de GUYON sobre os pactos parassociais é, justamente, a sua percepção de que esses contratos são internos ao fenômeno societário, e não se situam em seu exterior como poderia fazer sugerir o fato de que se consubstanciam em instrumentos diversos do contrato ou estatuto social ou que possam não gerar efeitos sobre a organização e funcionamento da sociedade.

Essa posição pode ser verificada na metáfora de que se vale GUYON para explicar o fenômeno, já referida: a sociedade seria a estrela maior de uma nebulosa contratual que a envolve. O estatuto refere-se a essa "estrela maior", enquanto os pactos parassociais dão sustentação à "nebulosa" em que ela se insere. O relacionamento societário, ora se conclui, é estruturado e regido por essa teia de instrumentos jurídicos que se imbricam mutuamente.

risolvere la questione dibattutta entro una logica meramente astratta e avulsa dalla realtà, mentre valutandole alla stregua di um criterio che tenga pari conto anche dei risultati giuridici provenienti dalla pratica applicazione del fenomeno in questione, esse si rivelano indubbiamente lacunose". Simulazione.., cit., p. 1121).

91 Como exemplo, Georges Ripert e G. Roblot, Traité de Droit Commercial, atual. Michael Germain, T. 1, Vol. 2 - Les Societés Commerciales; Géraldine GoffauXCallebaut, Du contrat..., cit. e Sophie Schiller, Les limites..., cit..

${ }^{92}$ Nesse peculiar, vale referir a bela nota de José Miguel EMBID IRUjo sobre a vida e obra de Guyon, em que ressalta o êxito ímpar que a obra Les Sociétés - Aménagemens statutaires et conventions entre associés alcançou na França e no exterior, tendo sido contemplada com o prêmio de melhor obra de prática jurídica pela Compagnie des AvocatsConseils d'Entreprises de Paris et de l'île de France. (Necrológica: Yves Guyon (19342005), in Revista de Derecho Mercantil, no 257, julho - setembro, 2005, pp. 1675-1677). 
GUYON contribui, portanto, para desfazer a impressão de que, porque não relativos necessariamente ao funcionamento da sociedade ou inseridos no estatuto social, pactos parassociais seriam imperceptíveis ao direito societário ${ }^{93}$.

Ao tomar os contratos parassociais como manifestações da autonomia contratual no direito societário, GUYON focaliza apropriadamente o cerne do problema: os contratos parassociais integram o arsenal com o qual as partes se armam na entabulação de um negócio societário e são tão ou mais relevantes que o próprio estatuto social ${ }^{94}$.

Seguindo o raciocínio de GUYON, parece ser crucial avaliar se a utilização desses instrumentos é compatível com os ditames, princípios e lógica próprios do relacionamento societário. A autonomia existente entre o negócio representado pelo estatuto social e o contrato parassocial passa a ser, sob o prisma do relacionamento a que ambos se referem, menos nítida, sobretudo tendo em vista que, em grande parte dos casos, as partes coincidem.

Em todos os casos, a contratação não poderia ferir o que a tradição francesa designa como ordem pública societária. Contudo, como é sabidamente impossível definir com exatidão o que se enquadra nesse

${ }^{93} \mathrm{Na}$ mesma linha, Georges Ripert e G. Roblot, Michel Germain (atual.), Traité de Droit Commercial, cit., p. 397.

94 A classificação proposta por GUYON para os contratos extra-estatutários engloba a) pactos sobre a situação dos associados; b) pactos sobre a situação dos dirigentes; c) pactos sobre a situação da sociedade (neles incluídos os acordos de voto e acordos para o financiamento da sociedade) e d) pactos celebrados por ocasião da liquidação e partilha (Les sociétés..., cit.). No presente trabalho, além dos acordos de voto, não se examina os pactos sobre a situação dos dirigentes por envolverem temas de direito do trabalho e, mais que isso, por trazerem à discussão aspectos ligados às preocupações com boas práticas de corporate governance. Os pactos ora estudados referem-se precipuamente a posições invididuais dos sócios, ainda que em benefício da sociedade (como acordos prevendo prestação acessória). SOPHIE SCHILler faz leitura peculiar do fenômeno, indicando a seguinte divisão dos pactos (ou "aménagements"): (i) acordos relativos à necessidade de una garantia para toda criação de atividade; (ii) acordos relativos à necessidade de uma proteção da garantia para todo o desenvolvimento de uma atividade; (iii) acordos relativos à conexão entre o poder e a responsabilidade entre os associados; (iv) acordos relativos à conexão entre o poder e a responsabilidade dos dirigentes e (v) acordos relativos à conexão entre o poder e a responsabilidade dos associados ou dirigentes para a conclusão de um contrato de caução (Les limites de la liberté contractuelle... cit.). 
conceito, GUYON evidencia a necessidade de se examinar os pactos parassociais ou extra-estatutários com vistas aos objetivos da ordem pública societária, que aponta serem a proteção dos minoritários, a igualdade dos acionistas e a proteção dos credores sociais ${ }^{95}$.

Nesse sentido, segundo o autor, seriam válidas as convenções que não contrariassem os objetivos da ordem pública societária, as estipulações imperativas dos estatutos e o interesse social ${ }^{96}$.

Ou seja, ao ampliar a análise dos pactos parassociais, preocupando-se com seus efeitos perante a ordem pública societária e não apenas perante a companhia, GUYON contribui significativamente para a construção do raciocínio que permeia este trabalho.

\section{Posição da doutrina brasileira}

$\mathrm{Na}$ doutrina brasileira os pactos parassociais são mais examinados com vistas a sua relação com a companhia, valendo-se, muito, da obra de OPPo.

Dentre as monografias mencionadas no Prólogo, não se encontrou, como já se apontou, obra que examinasse com profundidade o impacto dos contratos parassociais sobre a relação societária, ou seja, que tratasse dos ajustes parassociais dentro de sua real dimensão de instrumentos para acomodação de interesses das partes no seio da sociedade. Ao contrário, há várias obras que cuidam da natureza jurídica dos acordos de acionistas, suas várias classificações e as peculiaridades da legislação brasileira.

Sobre os limites de validade dos contratos parassociais derivados da própria noção de sociedade de direito societário - temas relevantes para a

\footnotetext{
${ }^{95}$ Cf. Les sociétés..., cit., p. 309.

${ }^{96}$ Essa posição será comentada adiante, no Capítulo 4.
} 
presente investigação, portanto - as menções são breves e pouco aprofundadas ${ }^{97}$.

\subsection{Proposta teórica de CALIXTo SALOMÃo Filho}

No cenário brasileiro, pois, pode-se indicar como um dos poucos textos com propósito claro de examinar o tema dos pactos parassociais sob enfoque eminentemente teórico o ensaio de Calixto Salomão Filho, Acordo de Acionistas como Instância da Estrutura Societária ${ }^{98}$.

Nele, o autor centra sua análise na existência dos centros parassocietários de poder e em como eles devem relacionar-se com a estrutura da sociedade. Parte-se do pressuposto de que apenas acordos que se integram na estrutura societária são capazes de produzir efeitos para além dos contratantes pois, em regra, "de sua característica parassocial decorre a impossibilidade destes modificarem a relação social. Podem apenas modificar as relações entre as partes, em certos casos com força vinculante para a sociedade" ${ }^{99}$.

Por decorrência, nessa leitura, os contratos ligados a compra e venda de ações e preferência não atingiriam a "relação social" ou a "estrutura da sociedade" ${ }^{100} \mathrm{e}$, assim, seriam irrevelantes para a disciplina societária. Nota-

\footnotetext{
97 Celso Albuquerque Barreto apresenta o seguinte rol de proibições aos pactos, demonstrando, assim, preocupação com seus efeitos sobre alvos de proteção do direito societário: “(a) indeterminação de escopo ou 'acordos em aberto', caracterizados pela inespecificidade do ajuste, quanto às matéria ou diretrizes do voto"; (b) cessão do direito de voto sem transferência da titularidade das ações; (c) negociação do voto (crime - art. 177, § $2^{\circ}$ do CP); (d) violação de direitos essenciais do acionista; (e) violação da legislação antitruste; (f) acordo danoso aos interesses da sociedade; (g) acordos que tenham por objeto as declarações de verdade (aprovação de contas etc)" (Acordos de acionistas, cit., p. 64). O autor, contudo, não examina com mais vagar cada um desses aspectos.

98 in O Novo Direito Societário, $3^{\mathrm{a}}$ ed. reformulada, São Paulo, Malheiros, 2002.

99 (Calixto Salomão Filho, Acordo de Acionistas..., cit., p.96)

100 Sobre os quais o autor assevera serem "[t]radicionais elementos de disciplina direta entre sócios, sequer cobertos pela lei societária (que não prevê disciplina específica para preferência na venda de ações e não traz disciplina de compra e venda, exceto o limite
} 
se, então, que o autor parece manter-se alinhado com OpPo, entendendo como relação social não o relacionamento complexo entre sócios, mas apenas aquilo que se pode observar por seus efeitos na sociedade.

Todavia, mais adiante no mesmo texto, reconhece que a interpretação de um pacto de preferência (i.e. sem efeitos diretos sobre a sociedade) somente pode ser adequadamente realizada se tomada a perspectiva societária - e não meramente contratual ${ }^{101}$. A justificativa seria a de que um ajuste dessa natureza consta de acordo que passou a integrar a estrutura societária.

Em que pese o pioneirismo da análise, não se evidencia qual a condição para que um ajuste parassocial venha a ser considerado como "integrante da estrutura societária" e, assim, sujeito à perspectiva do direito societário.

As dificuldades em lidar com o assunto são reconhecidas pelo autor, que afirma ser "interessante observar que as consequências da inserção do acordo de acionistas na estrutura societária parecem muito mais óbvias e naturais que a própria inserção como hipótese teórica" ${ }^{102}$.

Compreendendo essas dificuldades teóricas e compartilhando a preocupação de CALIXTO SALOMÃo FILHo quanto à possibilidade de interpretação de pactos com conteúdo diverso do voto pela ótica societária ${ }^{103}$, buscar-se, neste trabalho, examinar elementos para justificar a aproximação do direito societário a esses pactos.

genérico do art 109) essas regras em nada afetam a relação ou estrutura societária" (idem, ibidem).

101 Idem, p. 102.

${ }^{102}$ Idem, p. 103.

103 Prossegue o autor: "A relação fica mais evidente e necessária naqueles caos em que, antes que naturais, as consequências da inserção do acordo na estrutura societária geram problemas doutrinários. É o que ocorre no que respeita aos acordos sobre o exercício de voto (que são, de resto, o tipo mais comum). Aqui, de um lado, ressalta a característica societária (de fato) do acordo. De outro, a possibilidade de choque entre as disposições sobre voto dos estatutos e da lei" (idem, ibidem. Grifou-se) 


\section{Contratos parassociais patrimoniais: precisão terminológica}

Há uma categoria específica de contratos parassociais intensamente debatida na doutrina: os acordos de voto (voting agreements). As motivações que determinam a celebração desses acordos geralmente se ligam à estabilidade de poder dentro da companhia e/ou à reunião de minoritários para melhor defesa de seus interesses na sociedade.

As questões que surgem a respeito dos acordos de voto, assim, tocam temas muito relevantes para o direito societário, razão pela qual a doutrina jurídica construída a seu respeito é vastíssima, e as poucas regras legais existentes sobre o tema de contratos parassociais neles se concentram ${ }^{104}$. De fato, desde o início do século XX, a doutrina é abundante e detalhada sobre os acordos de voto e seus efeitos no direito societário ${ }^{105}$.

O voto, ao gerar consequências diretas na vida societária, é fator natural de atração do direito societário a referidos acordos, o qual impõe limites de validade, para que esses pactos não possam servir a propósitos

\footnotetext{
${ }^{104}$ Cf. item "Notas de comparação legislativa” no Capítulo 1.

105 Além das obras que tratam de acordo de acionistas e, portanto explicam a sistemática dos acordos de votos, cf. GASTONE COTTINo, Le convenzioni di voto nelle società comercialle, Milano, Giuffrè, 1958; Pier GiUsto JAEGER e Franco Bonelli (coord.), Sindacati di voto e sindacati di blocco, Milano, Giuffrè, 1993; MÁrio LeIte SANTOS, Contratos parassociais e acordos de voto nas sociedades anónimas, Lisboa, Cosmos, 1996; HARTMUT LÜBBERT, Abstimmungsvereinbarungen in den Aktien- um GmbH-Rechten der EWG-Staaten, der Schweiz und Großbritanniens, Baden-Baden, Nomos, 1971; CHARLES FREYRIA, Étude de la jurisprudence sur les conventions portant atteinte a la liberté du vote dans les sociétés, in Revue trimestrielle de droit commercial, n. ${ }^{\circ}$ IV, 1951, pp. 419. 437; Joaquim Garrigues, Sindicatos de Accionistas, in Revista de Derecho Mercantil, n. ${ }^{\circ}$ 55, Janeiro - Março, 1955, pp. 91-107. Giorgio SEmino, Il problema della validità dei sindacati di voto, Milano, Giuffrè, 2003; RAÚl VEnTURA, Acordos de voto: algumas questões depois do Código das Sociedades Comerciais (CSC, art. 17º), in Estudos vários sobre sociedades anônimas: comentários ao Código das Sociedades Comerciais, Coimbra, Almedina, 1992, pp. 7-101; VASCO DA GAMA Lobo XAVIER, A validade dos sindicatos de votos no direito português constituído e constituendo, in Revista da Ordem dos Advogados Portugueses 3 (dez. 1985), pp. 639-53; AAVV., Travaux de L'association Henri Capitat pour la Culture Juridique Française, T. X-Les consortiums d'actionnaires et la protection des minorités dans les sociétés anonymes (Journée de Berne). Vente à tempérament (Journée de Neuchatel), Paris, Librarie Dalloz, 1956.
} 
indesejados, conforme os preceitos de cada ordenamento jurídico ${ }^{106}$, sobretudo aqueles ligados à regulação do mercado de capitais.

Com relação às demais espécies de acordos extraestatutários ou parassociais, a multiplicidade de conteúdos que podem apresentar em decorrência dos diversos interesses que as partes procuram com eles tutelar dificulta que sejam agrupados em uma única categoria jurídica, sendo que, como adiante ver-se-á, esses outros ajustes não são examinados em profundidade na perspectiva de sua função no relacionamento societário existente entre os pactuantes.

Pouco se comenta, em sede doutrinária, sobre as variadas formas de contratos parassociais que não se identificam com acordos de voto. No mais das vezes, os autores enunciam e explicam as principais modalidades desses pactos sem, contudo, proceder ao exame sob o contexto da relação em que se fundam.

Por essa razão, a presente tese tem como objeto de análise, os pactos parassociais voltados exclusivamente a disciplinar direitos individuais $e$ patrimoniais de sócios, que ora se convenciona tratar por pactos parassociais patrimoniais $^{107}$ - em oposição, portanto, a contratos parassociais cujas cláusulas refiram-se a direitos sociais como o voto e temas correlatos, que afetem a organização da sociedade de forma direta e imediata ${ }^{108}$.

\footnotetext{
${ }^{106} \mathrm{Cf}$., por exemplo, o $\S 2^{\circ}$ do art. 118 da LSA, que determina que os "acordos não poderão ser invocados para eximir o acionista de responsabilidade no exercício do direito de voto (art. 115) ou do poder de controle (arts. 116 e 117)".

107 Ainda que a escolha terminológica possa se mostrar relativamente imperfeita, não se encontra na doutrina outra designação específica para o subconjunto de ajustes que se procura estudar, dentro do amplo conjunto dos pactos parassociais. Por outro lado, não parecendo igualmente correto deixar de incluir o termo parassociais para designar os contratos em exame, optou-se por qualificá-lo utilizando a mesma distinção entre direitos políticos e patrimoniais de que se vale a Lei n. 6.404/76 para evidenciar as diferentes prerrogativas conferidas aos acionistas.

108 Como acima se apontou Luigi FARENGA, na mesma linha, designa esse grupo de contratos como contratos parassociais extrassociais (contratti parasociali extrasociali), considerando que não geram efeitos sobre a organização da sociedade, mas apenas sobre direitos individuais dos sócios, em oposição àqueles que designam contratos parassociais
} 
Dito de outra maneira, os ajustes de que ora se ocupa dizem respeito, portanto, a posições patrimoniais e individuais (i.e., não políticas) de seus celebrantes, em oposição aos "contratos parassociais organizativos", os quais, relacionando-se a direitos políticos do acionista, possibilitam a interferência direta na organização e funcionamento da companhia (e, com isso, mais diretamente se verifica a sua sujeição ao direito societário).

Por óbvio, forçando-se a análise, mesmo o direito de voto tem conteúdo patrimonial, no sentido de que seu exercício pode gerar vantagens ou desvantagens para a companhia e para acionistas. Todavia, uma vez presente a proibição de negociação de voto ${ }^{109}$, os acordos que o tem por objeto são encarados sob a perspectiva de seu caráter de direito político do acionista. De outro lado, é evidente que os acordos patrimoniais são mais frequentemente acompanhados de acordos de voto que possibilitam sua concreção perante a companhia. Todos eles servem, como se viu, para ajustar a relação societária aos desígnios dos celebrantes.

Com a designação pactos parassociais patrimoniais, é preciso esclarecer, ainda, que não há a pretensão ou o intuito de apresentar rol completo de todas as suas manifestações ou mesmo detalhar o regime aplicável a cada um deles ${ }^{110}$.

stricto sensu, capazes de produzir efeitos sobre a organização da sociedade (acordos de voto e de administração, por exemplo) (I contratti parasociali, Milano, Giuffrè, 1987, pp. 224-25). Optou-se por não utilizar a mesma expressão, pois se entende algo tautológico chamá-los ao mesmo tempo parassociais e extrassociais. Fica registrada, de qualquer maneira, a proximidade de conceitos. Já na classificação proposta por OpPO, os contratos de que se ocupará são aqueles previstos nos grupos "a" (contratos celebrados por sócios com relação a seus direitos individuais) e "b" (contratos celebrados por sócios que geram benefício para a sociedade - mas não alteram ou têm o condão de alterar a sua organização).

${ }^{109}$ Código Penal, art. $177, \S 2$ - Incorre na pena de detenção, de 6 (seis) meses a 2 (dois) anos, e multa, o acionista que, a fim de obter vantagem para si ou para outrem, negocia o voto nas deliberações da assembléia geral.

${ }^{110}$ Como bem salientou Prof. Francisco SATIRo por ocasião do exame de qualificação da tese, esses pactos, pela complexidade que envolvem, ensejariam cada qual uma monografia ou tese a seu respeito. Deixe-se vincado, portanto, que não é o intuito do trabalho realizar 
Isso não apenas porque é impossível elencar e descrever todos os ajustes parassociais que a criatividade empresarial pode originar, mas também porque se tomou por base apenas pactos que, na experiência societária, são mais frequentes, quiçá típicos ${ }^{111}$.

Tem-se, assim, acordos de compra e venda de participações societárias (incluindo opções de compra e de venda - call options e put options) e cláusulas de saída conjunta (tag along e drag along rights clauses); acordos de preferência (first offer ou first refusal rights) ou sobre a transmissibilidade de ações (como a cláusula de aprovação, "clausola di gradimento", "clause d'agrement"); acordos de não-concorrência, permanência na sociedade (lock in) e não-restabelecimento e acordos prevendo prestação acessória com conteúdo patrimonial, incluindo obrigações de capitalização e financiamento, fornecimento e transferência de tecnologia, prestação de serviços ou conferência de bens em favor do empreendimento comum.

Esses ajustes, já se apontou, são comumente celebrados em momento anterior à constituição da sociedade ou ao ingresso de determinado sócio como parte do relacionamento societário, no bojo de acordos de associação, investimento ou joint venture. Nesse sentido, são mais frequentemente firmados por todos os sócios que se lançam em um empreendimento comum.

A nota unificadora desses variados pactos reside na incidência sobre a esfera patrimonial dos signatários, seja ela presente ou futura, mediata ou imediata, e o objetivo deste trabalho seria então, partindo dessa constatação,

ou pretender tamanha façanha: reunir em apenas uma tese de doutoramento o que seria objeto de várias delas.

111 É possível afirmar, com OPPO, que os pactos parassociais são demonstração do fenômeno da tipicidade social que não pode ser desconsiderado pelo intérprete ("a questo punto non è esagerato parlare di una certa tipicità sociale del fenomeno: tipicità che non può essere ignorata o sottovalutata dall'interprete" Le convenzioni parasociale tra diritto delle obbligazioni e diritto delle società, cit., p. 519). Conforme assinala PAULA A. Forgioni, com escólio em Bоввіо, “[a] prática reiterada e disseminada de atos dá origem a comportamentos socialmentes típicos ou à "tipicidade social" e, nesse sentido, pode-se vislumbrar certa "racionalidade espontânea" na formação do ordenamento jurídico" ( $A$ evolução do direito comercial... cit., pp. 237-238). 
apontar elementos de interpretação desses ajustes, considerando que suas disposições integram a disciplina que as partes de comum acordo escolheram para reger seu relacionamento societário.

\section{Inovação de perspectiva}

Tradicionalmente, os direitos patrimoniais e, sobretudo, o direito de propriedade, revelam-se como referências da autonomia contratual, e, portanto, sua submissão ao direito societário e seus princípios seria controvertida, se tomada posição ligada ao individualismo contratual ${ }^{112}$.

Talvez por essa razão, em que pese sua relevância na atual vida empresarial, os pactos parassociais que ora se designa "patrimoniais" não têm sido estudados de forma sistemática sob a perspectiva da lógica própria que informa o relacionamento societário, repetindo-se o simples argumento de que, dizendo respeito a direitos patrimoniais dos sócios e sendo autônomos do estatuto social, seriam regidos pela teoria geral dos contratos - o que não implica, entretanto, que estejam como que imunes ao regramento societário, a salvo da incidência de suas regras cogentes e de seus princípios.

\footnotetext{
112 Convém já reproduzir a lição de Menezes CoRdeiro que muito influencia os argumentos deste trabalho, com relação à ainda frequente "insensibilidade" na consideração de aspectos como a lealdade nas relações entre particulares: "[o] liberalismo e as codificações dele tributárias foram pouco sensíveis, no início, à ideia de lealdade. De resto, isso sucedeu, em geral, com os conceitos indeterminados que postulavam ordenamentos alargados para além do jus positum. Aos cidadãos eram reconhecidos direitos que eles exerceriam como bem lhes parecesse. Apenas era devida obediência aos contratos livremente celebrados e, naturalmente, à lei. Para além disso, não haveria mais "lealdades" exigíveis" (A lealdade no direito de sociedades, in Revista da Ordem dos Advogados, dez/2006, p. 2). Ademais, sobretudo em países da common law, o respeito ao contrato é extremo e, por essa razão que escapa à análise de aplicadores de direito menos prudentes, não é salutar reproduzir mimeticamente os pactos e convenções idealizados em ambiente institucional tão distinto do brasileiro. Cf. nesse ponto, LAURENT CONVERT, L'imperatif et le supplétif... p. 501 e ss ("en Angleterre, l'imperatif correspond en efet au respect de la liberté contractuelle, tandis que le supplétif intéresse l'application effective de la loi légiférée. C'est le contrat qui est obligatoire plus que la disposition légale. Les convetions doivent être respectées par le juge et par le législateur. La véritable loi est en conséquence d'essence contractuelle plus que parlementaire. La force obligatoire des conventions se pose en conséquence en des termes différents de ceux qui prévalent sur le Continent". Grifou-se).
} 
Para que sejam válidas, soluções contratuais não podem afrontar ou distorcer os fundamentos do direito societário, demandando do intérprete e do aplicador do direito o domínio dessas bases e a reflexão sobre o modo pelo qual forjam a liberdade contratual. Esse controle é tarefa árdua tendo em vista a criatividade dos indivíduos, a multiplicidade das necessidades que, sempre mais, surgem no mercado e as maneiras nem sempre evidentes pelas quais podem corromper as relações societárias e/ou afetar os alvos de tutela do direito societário. O sigilo desses contratos e sua frequente submissão à arbitragem costuma dificultar, por outro lado, sua análise ${ }^{113}$.

São raros, assim, os estudos que, para além das discussões específicas sobre acordos de voto, tratam de contratos celebrados no bojo de um relacionamento societário e que compõem aquele conjunto negocial complexo a que antes se referiu. Como já se mencionou, não se encontrou, no Brasil, obra em que essa perspectiva seja adotada e as respectivas conclusões sejam enunciadas com esse específico propósito ${ }^{114}$.

No Brasil, a discussão centra-se no acordo de acionistas e nas particularidades relativas a essa forma de contrato parassocial, prevista expressamente no art. 118 da Lei n. 6.404/76 para a disciplina (i) da compra e venda de ações, (ii) do direito de preferência em adquiri-las, (iii) do exercício do direito de voto e (iv) do exercício do poder de controle ${ }^{115}$.

Por consequência, a maioria dos estudos acadêmicos brasileiros sobre acordos de acionistas gira em torno (i) do caráter taxativo ou enumerativo do rol de matérias previstas no art. 118 da lei, bem como dos efeitos de uma ou outra posição no plano da validade; (ii) da execução específica prevista no

\footnotetext{
113 Consultou-se também, sem êxito, os anuários da ICC (International Chamber of Commerce) de Paris, em que decisões arbitrais são publicadas.

114 Os pareceres compilados pelo Prof. FABIO Konder Comparato em Novos Ensaios e Pareceres de Direito Empresarial, cit., são daqueles poucos textos em que o mesmo viés é observado. Não se encontrou, porém, obra que compilasse as conclusões que deles podem ser extraídos para a teoria geral do direito societário.

${ }^{115}$ Inserido pela Lei n. 10.303/2001.
} 
mesmo artigo; (iii) de considerações sobre sua eficácia e oponibilidade a terceiros; (iv) de sua rescisão, resilição ou denúncia; bem como de temas específicos dos acordos de voto ${ }^{116}$.

Como pano de fundo à discussão desses principais temas ligados aos acordos de acionistas fica a afirmação superficial de que eles - como também outros contratos entre acionistas cujas matérias extrapolam as previstas em lei - são regidos pelo direito geral das obrigações.

A ênfase em afirmar a submissão dos contratos parassociais ao direito geral das obrigações e à teoria geral dos contratos, contudo, foi feita por OPPO para salientar a distinção entre esses contratos e os estatutos e contratos sociais, tendo em vista os ditames específicos direcionados a esses últimos pelo direito societário e não de modo a afastar sua relevância no contexto societário vivido pelas partes ${ }^{117}$.

Sem refletir sobre esse ponto, permite-se que se obtenha impressão não devidamente contestada na doutrina brasileira ${ }^{118}$ - de que os contratos parassociais, porque distintos do contrato social e, sobretudo, quando não tratam das matérias previstas no art. 118 da lei acionária brasileira, não seriam sujeitos à disciplina societária, com o que não se pode razoavelmente concordar.

\footnotetext{
${ }^{116}$ A despeito da evidente relevância de tais questões, importa desde já frisar que sua análise será aqui empreendida apenas de forma ancilar, quando assim se mostrar útil para o desenvolvimento da tese. O esforço deste estudo é, precisamente, lançar luzes sobre problema que escapa àqueles tipicamente abordados pela doutrina pátria no que tange aos contratos parassociais.

${ }^{117}$ Cf. item 4.2, Capítulo 4.

${ }^{118} \mathrm{Na}$ maioria da produção doutrinária sobre o assunto, os juristas não esclarecem como o direito societário deve incidir sobre contratos parassociais, valendo-se de expressões vagas. Por exemplo, vide a observação de FABIO KOnDer Comparato: "a validade de tais negócios era, então (antes da Lei n. 6.404/76), como ainda é hoje, submetida às normas comuns do direito privado, a par das regras gerais do direito societário" (Eficácia dos acordos de acionistas, in Novos ensaios e pareceres de direito empresarial, Rio de Janeiro, Forense, 1981, p. 76. Grifou-se).
} 
Por consequência, ajustes parassociais que não se enquadram no rol de matérias previsto em lei, ou mesmo aqueles que, previstos no art. 118, refiram-se a direitos individuais dos sócios (e.g., compra e venda de ações), acabam por não receber a devida análise e interpretação sob a perspectiva do direito societário, podendo levar a resultados não acurados ${ }^{119}$.

Faz-se necessário, assim, examinar o modo pelo qual o direito societário impacta os pactos parassociais patrimoniais no direito brasileiro, propondo pautas para sua interpretação em consonância com seus princípios e fundamentos e com a relação societária desejada pelas partes ao celebrá-los.

Para que o direito societário cumpra seu papel de oferecer ao mercado instituições com um padrão mínimo de aceitação, conferindo segurança jurídica e viabilizando as relações entre os vários agentes econômicos, é imprescindível verificar essa sempre mais complexa realidade negocial formada pelos pactos parassociais patrimoniais que, ao intérprete menos atento, poderia ser tida por mero conjunto de contratos entre particulares (i.e., sem qualquer relevância para a disciplina societária) ${ }^{120}$.

Mais que simplesmente revisitar a posição de OpPo - e dos demais autores que trataram dos pactos parassociais - ou mesmo discuti-la, urge tomála como apenas um ponto de partida para, avançando, examinar os pactos parassociais patrimoniais considerando sua função na disciplina do relacionamento entre as partes que se associam em sociedade e, com isso, sua interpretação sob a égide do direito societário.

\footnotetext{
119 Realizada pesquisa na jurisprudência pátria, verificou-se a escassez de decisões judiciais que indiquem a aplicação do direito societário a contratos parassociais. Os julgados localizados apenas tangenciam o problema, não enfrentando claramente a questão. Para as poucas exceções, cf. a análise presente na seção ANÁlises JURISPRUDENCIAIS, ao final do presente trabalho.

${ }^{120}$ Essa posição é, de certa forma, resultante da transposição exagerada de noções obtidas em regimes de common law para a realidade brasileira.
} 


\section{Plano da Tese}

Diante do exposto, o cerne do trabalho reside na análise de elementos para a interpretação dos contratos parassociais patrimoniais no direito brasileiro, baseados nos princípios que informam nossa disciplina societária e a lógica própria dos relacionamentos societários em que esses pactos são celebrados.

Apresenta-se, então, considerações sobre o histórico da contratação parassocial (Capítulo 1), a caracterização dos pactos parassociais patrimoniais e sua função econômica (Capítulo 2), além da análise de sua disciplina jurídica no direito brasileiro (Capítulo 3).

No capítulo 4, examina-se possíveis elementos para a interpretação dos pactos parassociais no Direito brasileiro adotando-se a perspectiva eleita e apresenta-se algumas conclusões para a tese ora sustentada.

Nesse sentido, parte-se das regras tradicionais de interpretação, passando pelo exame de elementos que sustentam a lógica societária, e por alguns elementos geralmente apontados pela doutrina para indicar os limites da autonomia contratual no direito societário, examinando-se, ao final, a necessidade de respeito aos alvos de tutela do direito societário. 


\section{1 - HISTÓRICO DA CONTRATAÇÃO PARASSOCIAL}

\section{1 - Ponderações iniciais: disciplina societária centrada no contrato de sociedade e na caracterização dos tipos societários}

Ao se analisar a história das sociedades comerciais, nota-se que a utilização de contratos parassociais é relativamente recente, não tendo sido, via de regra, contemplada nas legislações.

De fato, apenas a partir da segunda metade do século XX é que a doutrina sobre o tema foi se consolidando e ordenamentos como o Brasil (1976) e Portugal (1986) passaram a contar com algumas regras específicas sobre contratos parassociais.

Antes de se passar a um breve excurso histórico sobre a evolução legislativa e doutrinária da questão, com a simples finalidade de oferecer ao leitor panorama do cenário em que os argumentos da tese foram colhidos, cumpre lembrar que até o início do Séc. $X X$ a sociedade foi tida, essencialmente, como um contrato ${ }^{121}$. Natural, portanto, que as primeiras legislações elegessem esse contrato como centro da disciplina societária ${ }^{122}$.

\footnotetext{
${ }^{121}$ De fato, o surgimento da personalidade jurídica, de um lado, e o desenvolvimento das companhias, de outro, é que aos poucos foram permitindo a visão da sociedade como uma instituição que ultrapassa o contrato que lhe dá origem. Nesse sentido, Menezes Cordeiro aponta, com relação ao período de elaboração do Code de Commerce, "[a] doutrina da
} 
Por outro lado, conquanto pareça evidente, deve-se recordar que a sociedade, vista como reunião de esforços e recursos de um grupo de pessoas físicas ou jurídicas para um fim econômico comum, prescinde de qualquer contrato escrito para sua existência.

O que depende de certas condições - dentre elas a celebração de um contrato/estatuto com conteúdos mínimos previstos em lei - é a atribuição, pelo ordenamento jurídico, de características específicas conforme o tipo societário escolhido ${ }^{123}$ : a personalidade jurídica e a responsabilidade limitada.

A legislação societária se ocupa de indicar quando e como esses efeitos jurídicos são autorizados pelo ordenamento e o tratamento que se deve dar à sociedade que não os ostenta.

Essas considerações podem esclarecer a ausência de manifestações de contratação extraestatutária/parassocial nos períodos em que, tomadas as

\footnotetext{
época logo apurou que a "sociedade" tanto designava o contrato do mesmo nome como o "corpo moral formado por vários sócios" (Manual ..., cit. p. 45). Completo estudo da evolução da concepção da sociedade como um contrato, desde os tempos romanos, pode ser encontrado em Claude Champaud, Le contrat de société existe-t-il encore?, in LoÏC CADiet (org.), Le droit contemporain des contrats, Paris, Economica, 1987, pp. 125-39. Não se retomará, aqui, discussão sobre a caracterização da sociedade como contrato ou instituição.

${ }^{122}$ Explica Menezes CordeIro que "[i]nicialmente, as sociedades comerciais surgiam nos códigos de comércio, como um contrato entre outros. Ao longo do século XIX e do século $X X$, elas ganharam uma projecção que obrigou a múltiplas intervenções legislativas e que possibilitou sérios alargamentos doutrinários e jurisprudenciais. Desprenderam-se então, da vertente cooperativa, dando azo a circunstanciadas organizações jurídicas. Progressivamente, a matéria foi retirada dos códigos de comércio, surgindo em leis extravagantes" (Manual de direito das sociedades, cit., p. 45).

${ }^{123} \mathrm{Na}$ evolução das formas societárias, o reconhecimento de restrições à regra geral da responsabilidade ilimitada dos sócios nasceu como um privilégio, durante o período em que as companhias - fundadas sobre a responsabilidade limitada dos acionistas dependiam, justamente, de concessão para existirem. No curso do século XIX, muito embora a constituição das companhias não mais dependesse de outorga de autorização por parte do Estado, elas somente seriam legalmente reconhecidas se o estatuto e a organização da sociedade atendessem a condições estabelecidas em lei e submetidas a registro em órgão estatal. Cf. a síntese de KLAus J. HOPT a respeito em Gestaltungsfreiheit im Gesellschaftsrecht im Europa - Generalbericht in Gestaltungsfreiheit im Gesellschaftsrecht - ZGR Sonderheft 13 - org. Marcus LutTer e Herbert Wiedemann, Walter de Gruyter, Berlin, 1998, p.124.
} 
formas preponderantes de sociedade, inexistia sequer a necessidade de contrato escrito/estatuto para regular o relacionamento entre os sócios.

Por consequência, tudo o que fosse necessário acrescer ou alterar à disciplina concordada, ou ainda complementar à regra legal, poderia ser pactuado e repactuado (verbalmente) entre os sócios, sem que a questão da parassocialidade fosse levantada, muito embora, na prática, já ocorresse.

Em outras palavras: só faz sentido falar em contratação parassocial ou extraestatutária a partir do momento em que (i) as regras sobre a necessidade ou a imposição de elaboração de um estatuto, bem como sobre outros aspectos da vida societária foram se tornando mais presentes nas legislações e adquirindo caráter cogente, reduzindo e autonomia das partes na organização da sociedade ${ }^{124}$ e, de outro lado, (ii) a complexidade da vida negocial passou a gerar novos interesses na relação societária ${ }^{125}{ }_{-}^{126}$, especialmente no decorrer do último século.

\footnotetext{
${ }^{124}$ Quanto mais a legislação enrijece a utilização de determinando instituto, com intensa restrição da autonomia contratual, é natural que as partes busquem formas alternativas para alcançar o mesmo objetivo. No caso específico em discussão, quanto mais o direito societário foi se tornando detalhado e complexo, restringindo a autonomia de redação do estatuto social, o interesse das partes em contratar a regulação de seus interesses em contratos paralelos aumentou consideravelmente. No dizer de SophiE SCHILler, "[p]lus le droit des sociétés est organisé par des règles précises, plus la liberté contractuelle est utilisée" (Les limites de la liberté..., cit., p. 3).

${ }^{125}$ Celso Barbi Filho aponta a diversidade de interesses no seio da companhia como a matriz histórica da necessidade de celebração de pactos parassociais. Cf. Acordo de Acionistas, Del Rey, Belo Horizonte, 1993, p.21.

${ }^{126}$ O fenômeno é bem compreendido e sintetizado por DAigre e Sentilles-Dupont: "Os pactos de acionistas nasceram e se desenvolveram ao sabor das circunstâncias. Seu desenvolvimento provém, pelo essencial, da concentração das empresas, da restruturação dos grupos, da cooperação entre as sociedades, da diluição do capital dos grandes grupos e da diversificação das fontes de financiamento das empresas, grandes ou médias, que apelaram mais e mais aos aportes em fundos próprios" ("Les pactes d'actionnaires sont nés et se sont développés au gré des circonstances. Leur développement provient, pour l'essentiel, de la concentration des entreprises, de la restructuration des groupes, de la coopération entre les societés, de la dilution du capital des grandes groupes et de la diversification des sources de financement des entreprises, grandes ou moyennes, qui ont de plus en plus fait appel aux apports en fonds propres". Pactes d'Actionnaires, cit., p. 2).
} 


\section{2 - Evolução no direito brasileiro}

\subsection{1- O Código Comercial Brasileiro de 1850}

O Código Comercial Brasileiro, de 1850, cuidava das "companhias de comércio ou sociedades anônimas" em seus arts. 295-99, tendo por modelos os códigos francês ${ }^{127}$ e português ${ }^{128}$.

Uma peculiaridade, porém, fez com que o diploma influenciasse sobremaneira o tema dos contratos parassociais no direito brasileiro, ecoando até hoje: o art. 302 previa expressamente a nulidade de "[t]oda a cláusula ou condição oculta, contrária às cláusulas ou condições contidas no instrumento ostensivo do contrato".

Não obstante toda a construção doutrinária que se seguiu, sobretudo a seminal obra de Giorgio Oppo tratando dos termos da relação de

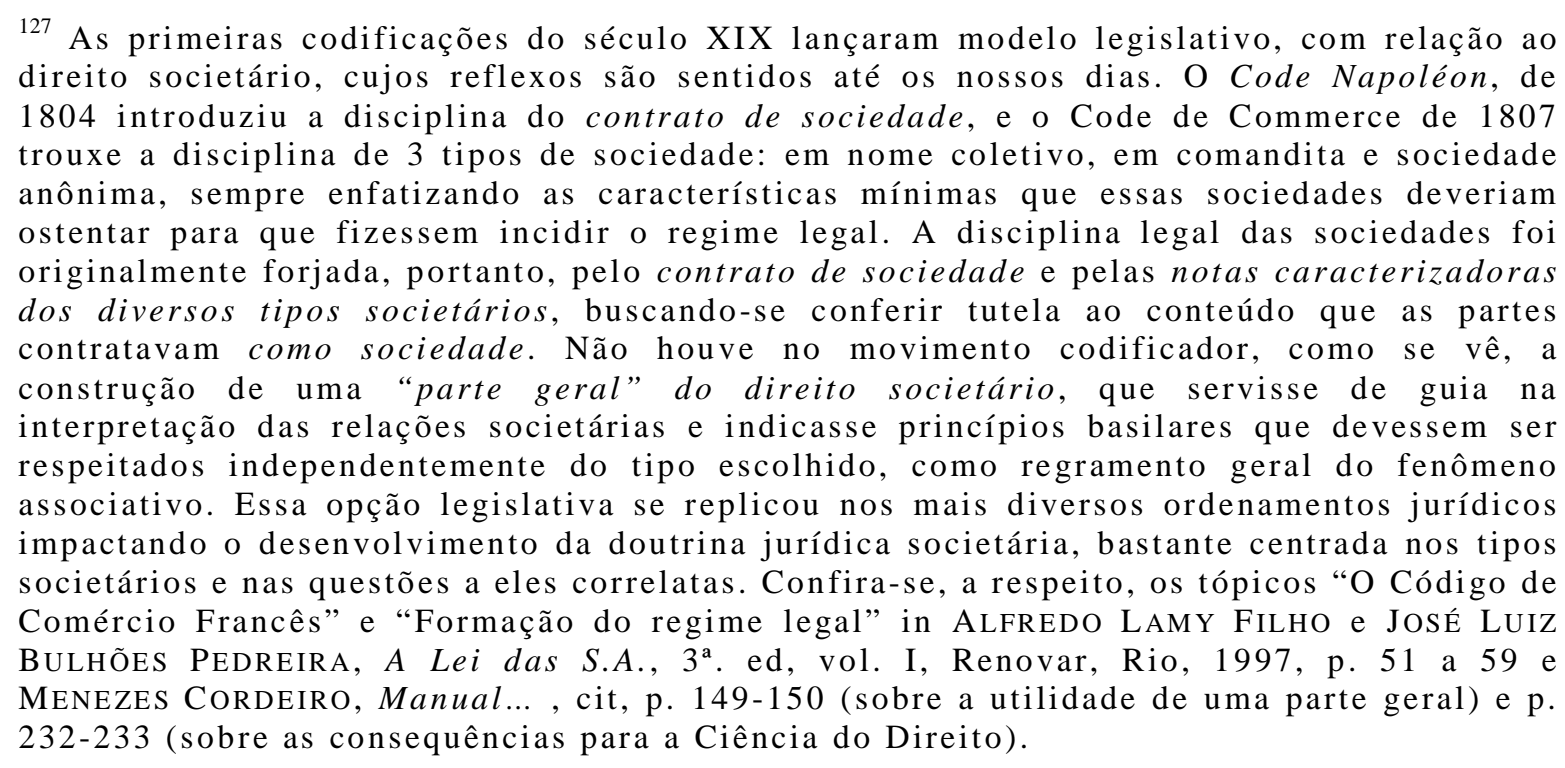
${ }^{128}$ Aponta Trajano de Miranda Valverde que “[o] Código Comercial, publicado nesse ano (de 1850), que entrou em execução em $1^{\circ}$ de janeiro de 1851 , teve como modelos, nem podia deixar de ser assim, os códigos francês e português. Foi, como os precedentes diplomas, excessivamente avaro no regular as sociedades anônimas. Admite as ações ao portador, porém declara que elas se transferem por via de 'endôsso'. Facilitou, com linguagem imprópria, interpretações errôneas, se bem que, no art. 296, mantenha a diferença entre escritura, estatutos e ato de autorização. Nada diz sôbre a reunião ou a assembléia dos acionistas" (Sociedades por ações, Vol. 1, Rio de Janeiro, Forense, 1941, p. 16. Destacou-se). 
acessoriedade entre contrato social e parassocial, a cominação de nulidade pelo art. 302 do Código Comercial de 1850 acabou por gerar espécie de "ranço" sobre a contratação extraestatutária, como que a tornando, prima facie, suspeita ${ }^{129}$.

No momento da contratação, quase sempre é impossível esquadrinhar todos os aspectos pelos quais algo pode ser tido como contrário "às cláusulas ou condições contidas no instrumento ostensivo do contrato". Na dúvida, inexistindo critérios objetivos para dotar essa interpretação de maior segurança ou mesmo previsão legal expressa, evitou-se quanto possível a celebração de contratos diversos do estatuto ou contrato social ${ }^{130}$.

\subsection{2 - Final do século XIX e começo do XX: leis acionárias brasileiras e a} proliferação dos sindicatos de voto

Após a promulgação do Código Comercial em 1850 seguiram-se leis específicas sobre sociedades anônimas no direito brasileiro, que, entretanto, nada previram com relação aos contratos parassociais (ou seja, contratos entre sócios diversos do estatuto social) e, em especial, aos sindicatos de voto que começavam a despontar também no Brasil.

\footnotetext{
${ }^{129}$ Nesse sentido, informa Tavares Guerreiro que, "é frequente ouvir-se, de pessoas alheias à experiência societária contemporânea, que os chamados acordos de acionistas, na verdade, constituem expediente maligno mercê do qual se convencionam ajustes ilícitos, práticas abusivas, manobras fraudulentas. Essa visão do instituto, assim preconceituosa como superficial, não raras vezes adotada por certos militantes do direito, não afeitos à extraordinária vitalidade com que se desenvolve em nossos dias a disciplina jurídica das atividades empresariais. Refere-se, vez ou outra, a antiga aversão do direito francês aos pactos parassociais. Traz-se à colação, à guisa de reforço argumentativo, a parte final do art. 302 de nosso Código Comercial, que fulmina de nulidade "toda cláusula ou condição oculta, contrária às cláusulas ou condições contidas no instrumento do contrato (social)". in Prefácio à obra de Celso Barbi Filho, Acordo de Acionistas, cit., p. 9. Cf., também, W ALDirio BUlgarelli, Anotações sobre o acordo de cotistas, in RDM 98, p. 44 e ss.

${ }^{130}$ Como adiante se verá, essa situação perdurou até o advento da lei 6.404/76 e foi mesmo um dos motivos que levaram o legislador a prever expressamente os acordos de acionista no art. 118 da lei. Com relação aos acordos celebrados em sociedades limitadas, entretanto, a Lei n. 6.404/76 não foi suficiente para aplacar as dúvidas sobre a validade de acordo de quotistas, conforme será abordado no item 1.2.5, abaixo.
} 
A ausência de menções a contratos parassociais seja nas leis, seja nos comentários que a elas se fizeram ${ }^{131}$, indicam inexistência de preocupação efetiva, no Brasil, em oferecer disciplina legal específica voltada aos contratos celebrados com vistas a interesses ínsitos ao relacionamento societário, mas de forma paralela ao contrato social.

Por outro lado, na Europa, o período foi fértil em discussões sobre validade dos sindicatos de voto, que experimentavam, então, grande desenvolvimento ${ }^{132}$.

1.2.3 - Os contratos parassociais sob a disciplina societária do Decreto-Lei n. $2627 / 40$

Paralelamente ao desenvolvimento da teoria de OpPo sobre os contratos parassociais, em 1942, no Brasil vigia o Decreto-Lei n. 2.627/40, que não trazia menção expressa e direta à contratação parassocial ${ }^{133}$. O único dispositivo a relacionar-se indiretamente ao tema era o art. 27, que previa a possibilidade de estabelecimento de limitações à circulabilidade das ações ${ }^{134}$.

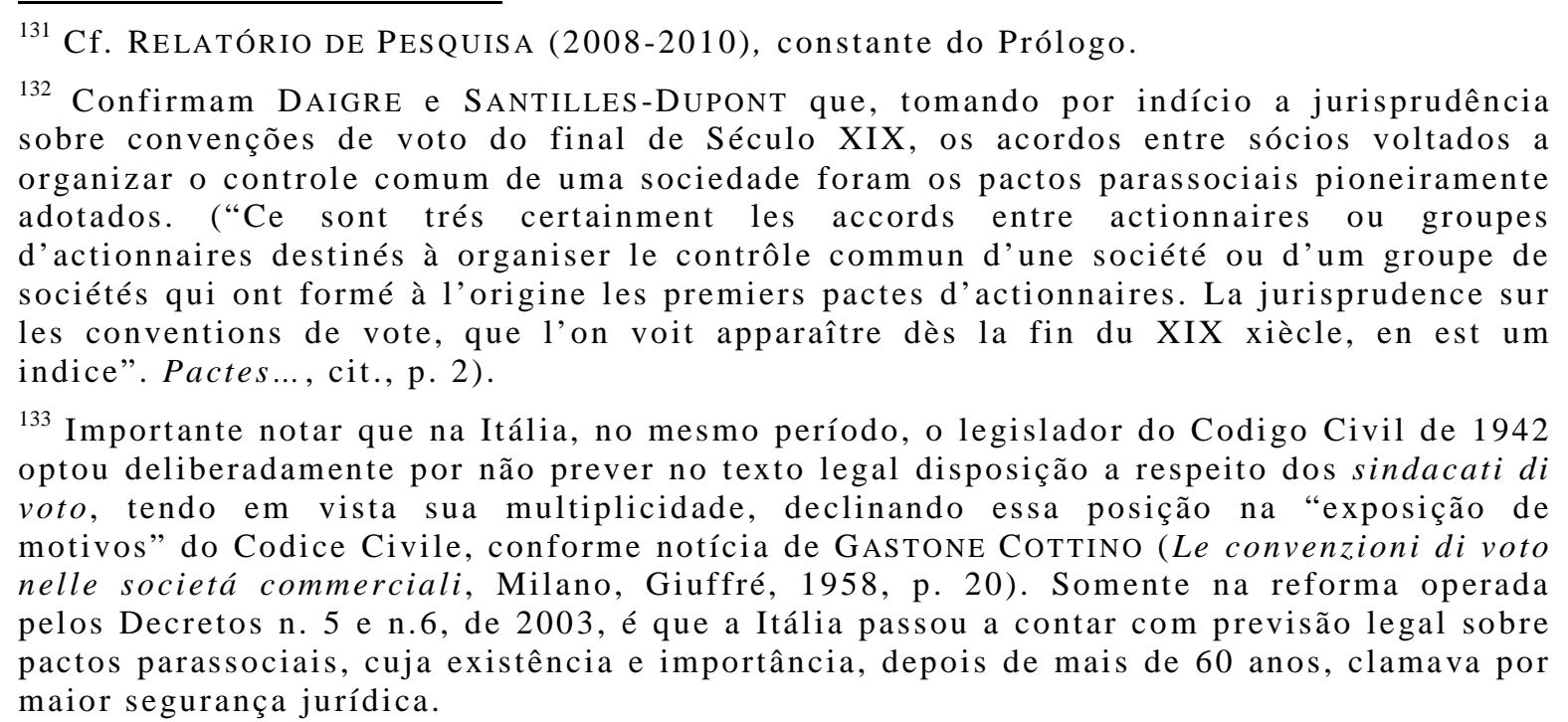
134 Ainda que presentes no estatuto social, as limitações à circulação de ações podem ser tidas como pactos parassociais de conteúdo patrimonial, no sentido material conferido a esses contratos (GUYON professa essa opinião. Cf. Les sociétés..., cit. pp. 31-33). Não obstante, esse prisma de análise não foi desenvolvido na ocasião. A caracterização de pactos como materialmente ou formalmente extra-estatutários, segundo o autor depende de 
A doutrina da época, assim, concentrava-se no exame da validade dos acordos de voto no direito brasileiro, sem tratar de outras hipóteses de contratos parassociais ${ }^{135}$.

Em que pese essas considerações, a prática societária foi recepcionando ajustes parassociais com conteúdos variados. O pós-guerra e as peculiares condições econômicas geradas permitiram elevado volume de investimentos que, em grande parte, traziam consigo a necessidade de disciplinar o relacionamento societário de forma mais complexa e sofisticada.

No Brasil, essa fase corresponde à industrialização da economia e às grandes modificações econômico-sociais que dela decorreram. A partir dos anos 60, o então BNDE (Banco Nacional de Desenvolvimento Econômico) desempenhou importante papel na disseminação dos acordos de acionistas, ao vincular o investimento em companhias à sua celebração ${ }^{136}$.

De outro lado, o aumento no volume de operações de joint ventures estimulado pelo crescimento industrial, com a atração de investimentos estrangeiros contribuiu para a consolidação dos acordos de acionistas na prática societária nacional, malgrado a ausência de regra legal específica ${ }^{137}$.

suas disposições constarem apenas formalmente no estatuto, mas materialmente não corresponderem a cláusulas estatutárias voltadas à organização e ao funcionamento da sociedade.

135 V. Francisco Cavalcanti Pontes de Miranda, Tratado de Direito Privado, Tomo L, São Paulo, RT, p. 298 e ss., para histórico da questão e análise das legislações em que, à época, debatia-se a validade dos acordos de voto. Não se encontra na obra do grande tratadista baiano, entretanto, menção a outros contratos parassociais. Modesto CARVAlHos a retrata em detalhes o embate doutrinário no direito brasileiro, sob a égide do Decreto-lei 2627/40 (Comentários à lei das Sociedades Anônimas, $3^{\mathrm{a}}$ ed., São Paulo, Saraiva, 2003, vol.2. p.514-516).

${ }^{136}$ Cf. Modesto Carvalhosa, Comentários..., cit., p. 516. Celso Barbi Filho, Acordo...,. cit, p. 35.. Mesmo na Europa, a atividade de investimento em capital de risco (capitalrisque) de bancos de investimento tanto estatais como privados foi fator determinante para a expansão da utilização diuturna de pactos parassociais. A respeito, cf. JEAN-JACQUES DAIGRE, Pacte d'actionnaires et capital risque - Typologie et appréciation, in Bulletin Joly Sociétés, 1993, n. 2, p. 157-158.

137 CARvalhosa refere a utilização dos acordos nas joint ventures, sobretudo com participação estrangeira (Comentários, cit., p. 516). Igualmente, LAMY FILHO e BulHõES PEDREIRA, A lei das S.A, cit., p. 91. 
A segurança na celebração de acordos de acionistas ou pactos parassociais, entretanto, não era satisfatória.

De um lado, a ausência de regra legal explícita permitia que os juízes ainda se apegassem às teses mais conservadoras sobre as convenções de voto, determinando a sua invalidade ${ }^{138}$. De outro, como referiu-se, o art. 302 do Código Comercial de 1850 continuava vigente, gerando suspeita sobre eventuais contratos celebrados para além do estatuto social.

Nesse cenário, junto de muitas outras exigências, houve-se por bem realizar a reforma do diploma acionário, de modo a torná-lo compatível com a pujança permitida pelo milagre econômico vivenciado no Brasil no início dos anos 70 .

1.2.4 - Lei n. 6.404/76: edificação de novo sistema de direito societário brasileiro

\section{a) Contexto}

A reforma da legislação societária, que culminou com a promulgação da lei 6.404 de 15 de dezembro de 1976, teve por objetivo declarado "criar modelo de companhia adequado à organização e ao funcionamento da grande empresa privada, requerida pelo atual estágio da economia brasileira" ${ }^{139}$.

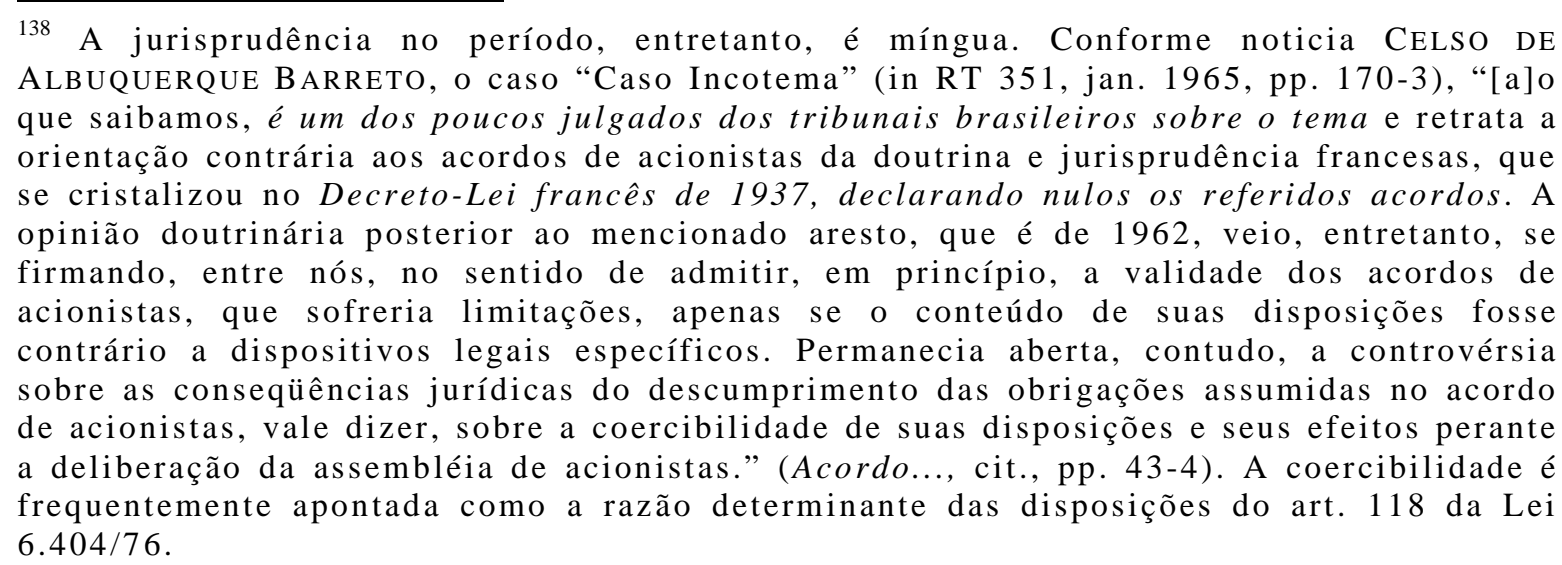

${ }^{139}$ Cf. Lamy Filho e Bulhões Pedreira, A Lei das S.A., cit., vol. I, p. 135. 
Por consequência, os juristas encarregados da elaboração do Anteprojeto, Alfredo Lamy Filho e José Luiz Bulhões Pedreira esmeraram-se em criar diploma consentâneo com os mais expressivos avanços no direito societário, inspirando-se, sobretudo, na lei societária alemã de 1965 e em institutos consagrados no direito norte-americano.

Como resultado, deu-se uma revolução no cenário societário brasileiro, com a construção de verdadeiro sistema aplicável às sociedades anônimas. Um todo completo, organizado, cuidando de inúmeros aspectos sobre os quais, até então, pouco se comentava seja em doutrina que em jurisprudência nacionais ${ }^{140}$.

Ao longo de sua vigência, e em que pesem as alterações pontualmente realizadas, o sistema previsto na lei das sociedades anônimas foi-se consolidando e o diploma é frequentemente apontado, como um dos mais modernos do mundo, tendo em vista a época de sua promulgação.

\footnotetext{
${ }^{140}$ Importante notar que a Lei $6.404 / 76$, muito embora tenha trazido dispositivos aplicáveis a outros tipos societários, sobretudo com relação às regras contábeis e de operações de reestruturação societária, foi concebida como uma lei especial sobre sociedades anônimas, não havendo a intenção de criar um código geral de sociedades, com enunciação de princípios basilares ao fenômeno associativo. A respeito, LAMY FILHO e BULHões PEDREIRA esclarecem os argumentos que fundamentaram a decisão: "a inconveniência de ficarem sujeitas à inevitável inflexibilidade dos códigos sobre normas relativas às sociedades empresárias em geral, e, muito especialmente, às sociedades anônimas; a importância da Lei das S.A. como instrumento de política econômica; a significação da Lei das S.A como forma de organização da grande empresa, essencial no processo de desenvolvimento econômico brasileiro, e a necessidade de sua integração com a legislação que disciplina os mercados de valores mobiliários; e a conveniência de preservar a flexibilidade de adaptação da lei às frequentes transformações de uma economia em rápido desenvolvimento e das economias modernas, que revelam evidente tendência para homogeneização do regime legal, incompatível com o esforço de codificação, que supõe a permanência no tempo" (A Lei das S.A., cit., vol. I, p. 132-133). Como o tempo demonstrou, entretanto, a longa gestação do então projeto de Código Civil fez com que a Lei das S.A funcionasse como lei geral de sociedades sem, entretanto, ter sido elaborada com essa finalidade e sem ter sido dotada, por consequência, de dispositivos aptos a fornecer bases para a teoria geral de sociedades no direito brasileiro.
} 
b) Posição de vanguarda: previsão legal de acordos de acionistas no art. 118 da Lei 6.404/76.

Dentre as incontáveis inovações buscadas pelo legislador e levadas a efeito com maestria pelos responsáveis pela redação da lei 6.404/76, uma das mais corajosas foi, precisamente, a previsão explícita de acordos de acionistas $^{141-142}$.

Não se limitou o legislador a enunciar legalmente o que já ocorria na prática, validando os contratos e convenções entre acionistas. Ao contrário - e nisso reside a verdadeira audácia - incluiu regra tratando dos efeitos de referidos negócios jurídicos perante a companhia; sua oponibilidade perante terceiros; bem como a execução específica das disposições contratuais, determinando as matérias que, previstas no contrato, autorizariam a incidência plena dessas regras (exercício do direito de voto e a compra e venda de ações e preferência para adquiri-las) ${ }^{143-144-145}$

141 Para reprodução das justificativas quanto à conveniência e oportunidade de dar tratamento específico aos acordos de acionistas na lei 6.406/76, v. LAMY FILHO e BULHÕES PedreirA, A Lei das S.A., cit., vol. I, p. 154. De modo especial, esclarecem os autores da lei, após sua promulgação, que: "[o] art. 118 regula o acordo de acionistas - modalidade contratual de prática intensa em todas as latitudes, mas que os códigos teimam em ignorar. Ocorre que essa figura jurídica é da maior importância para a vida comercial, e a ausência de disciplina legal é, certamente, a causa de grande número de abusos e malefícios que se lhe atribuem" (idem, p. 238).

142 Esclarece-se que, "[s]ensível a exigências práticas da vida negocial, o legislador de 1976 houve por bem prestigiar o instituto, consagrando-o como instrumento hábil a preencher suas verdadeiras finalidades, tais como desejadas pelas partes contratantes." (Egberto Lacerda Teixeira e José Alexandre TAvares Guerreiro, Das sociedades anônimas no direito brasileiro, vol. 1, São Paulo, Bushatsky, 1979, p. 303). Cf. também CARvalhos A, Comentários..., cit. p. 543.

143 Sobre o critério taxativo ou enumerativo do rol de matérias constante do texto legal, bem com os efeitos dele decorrentes, cf. o Capítulo 3, a seguir.

${ }^{144}$ Confirma Carvalhosa que "[a]o disciplinar a espécie, o diploma vigente foi inovador, não quanto ao conteúdo de tais avenças, que obedecem à tradição hoje universalmente consagrada, mas pelo fato de ser praticamente uma das primeiras leis que de maneira direta trata da matéria, antecipando-se, na época, ao projeto da sociedade anônima européia. Por outro lado, concretiza o que, a respeito, propunham outros anteriores projetos de reforma, notadamente o de Ascarelli e o formulado por De Gregorio (esse último tratava apenas dos sindicatos de voto)" (Comentários, cit. p. 517). 
Assumiu-se, portanto, posição totalmente diversa daquela que se consolidou na Europa, sobretudo nos países latinos ${ }^{146}$, a respeito da limitação de efeitos de contratos parassociais a seus contratantes ${ }^{147}$.

Com relação à proposta do presente trabalho, é fundamental observar que a particularidade de contarmos, desde 1976, com previsão legal expressa sobre aspectos tão relevantes ao tema dos pactos parassociais no direito brasileiro fez com que seu estudo devesse, necessariamente, passar pela avaliação teórica desses mesmos aspectos.

Por consequência, desde a promulgação da lei, nossa doutrina se debruça sobre os acordos de acionistas e suas características próprias, legalmente moldadas ${ }^{148}$. É preciso, porém, avançar doutrinariamente em pontos

\footnotetext{
${ }^{145}$ Ver-se-á no Capítulo 3, contudo, que a execução específica de contratos já era prevista no CPC de 1973.

146 Confirmam essa posição, na Itália, RAFFAele TORINo, ao comentar os acordos de bloqueio ("mentre le clausole statutarie hanno uma efficacia c.d. reale, risultando la loro violazione inoppobile alla società e priva di efficacia nei suoi confronti, i patti parassociali di blocco - come tutti i conttratti parasociali - hanno un'efficacia meramente obbligatoria, vincolano solo i contraenti che vi partecipano e la loro violazione, dal punto di vista della società non rileva in alcun modo in merito al valido ed efficace trasferimento della partecipazione" I Nuovi Contratti Nella Prassi Civile e Commerciale, Torino, UTET, 2004, p. 189) e LUCA BUTTARo ("vincolano unicamente le parti contraenti e no possono essere fatti valere nei confronti della società, data la sua qualità di terzo") Verbete "Sindacati Azionari", in, Antonio AzAra e ERnesto Eula (coord.), Novissimo Digesto Italiano, Torino, UTET, 2010, p. 426).
}

147 Deve-se esclarecer, porém, que o direito alemão no qual se inspirou o legislador foi precursor na aceitação judicial de execução específica de contratos, com geração de efeitos para a companhia. Noticia Menezes Cordeiro: "Admitidas - salvo determinadas limitações (...) as convenções de voto, a Ciência Jurídica alemã tiraria diversas e importantes conclusões, quanto ao seu regime. Assim, as convenções de voto foram consideradas susceptíveis de execução específica, quanto inobservadas. (...). A jurisprudência admitiu esta orientação, na decisão liderante e já citada do BGH 29-mai1967" (em Acordos parassociais, in Revista da Ordem dos Advogados, Portugal, 2001, II, p. 533). Mais adiante (p. 539) o autor examina a questão em comparação ao direito português, esclarecendo que "não é possível - contra o que vimos ocorrer no Direito alemão - a execução específica de acordos parassociais. Repare-se: o voto tem efeitos societários: não meramente "obrigacionais". Admitir uma acção de cumprimento (...) seria conferir, ao acordo parassocial uma eficácia supra partes. O Direito alemão admite-o; o Direito português não" (p.539).

${ }^{148}$ Na síntese de Celso BARBi FIlho, “[o] acordo de acionistas, tal como disciplinado no direito brasileiro, é um instituto ímpar, que não encontra paradigma idêntico no direito estrangeiro. Assim sendo, a solução das questões mais específicas, surgidas por sua utilização em nosso ordenamento, encontra-se, muitas vezes, sem qualquer subsídio 
que, pela própria evolução da matéria societária, nem o legislador de 1976, nem a jurisprudência puderam alcançar, com vistas ao universo mais amplo dos pactos parassociais que não se limita à hipótese legal ou, melhor dizendo, não se confunde ou se identifica plenamente com ela.

\section{c) Redação original do artigo 118 da Lei 6.404/76}

Tornando à disposição legal, previa originariamente o artigo 118 da Lei 6.404/76 que seriam respeitados pela companhia, quando arquivados em sua sede, os acordos de acionistas sobre o exercício de direito de voto, a compra e venda de suas ações e a preferência para adquiri-las ${ }^{149}$.

Seriam estas as matérias a que, à época, portanto, entendeu-se necessário conferir os efeitos previstos na lei: a produção de efeitos perante a companhia, a oponibilidade a terceiros e, por fim, a execução específica. No Capítulo 3 serão tratadas as principais discussões derivadas dessa escolha.

d) Alterações no artigo 118 pela lei $10.303 / 2001$

Após vinte e cinco anos de aplicação da lei, o artigo 118 sofreu alterações de modo a atender novas exigências da prática societária brasileira, relativas à utilização sempre mais larga de acordos de acionistas para a

externo. Por isso, cabe aos juristas brasileiros a construção doutrinária do perfil e dos princípios do instituto em nosso direito" (Acordo ..., cit., p. 8 - grifou-se). Entende-se que esse esforço já tem sido realizado, e, portanto, não é objetivo do trabalho juntarmo-nos à essa linha de pesquisa mas, partindo dela, considerar o tratamento de outros contratos parassociais no direito brasileiro.

149 Redação original: Art. 118. Os acordos de acionistas, sobre a compra e venda de suas ações, preferência para adquiri-las, ou exercício do direito de voto, deverão ser observados pela companhia quando arquivados na sua sede. $\S 1^{\circ}$ As obrigações ou ônus decorrentes desses acordos somente serão oponíveis a terceiros, depois de averbados nos livros de registro e nos certificados das ações, se emitidos. $\S 2^{\circ}$ Esses acordos não poderão ser invocados para eximir o acionista de responsabilidade no exercício do direito de voto (artigo 115) ou do poder de controle (artigos 116 e 117). § $3^{\circ}$ Nas condições previstas no acordo, os acionistas podem promover a execução específica das obrigações assumidas. § $4^{\circ}$ As ações averbadas nos termos deste artigo não poderão ser negociadas em bolsa ou no mercado de balcão. $\S 5^{\circ}$ No relatório anual, os órgãos da administração da companhia aberta informarão à assembléia-geral as disposições sobre política de reinvestimento de lucros e distribuição de dividendos, constantes de acordos de acionistas arquivados na companhia. 
consolidação do poder de controle, sobretudo no que se refere à execução dos acordos de voto.

Em primeiro lugar, cuidou-se de incluir o exercício do poder de controle como matéria objeto dos efeitos específicos previstos pela lei. Com isso, passou-se a considerar, legalmente a figura dos pooling agreements, mediante a qual os acionistas signatários do acordo, reunidos previamente, decidem por maioria o sentido que deve ser dado ao voto do grupo ${ }^{150}$.

Buscou-se, então, conferir eficácia ainda mais plena aos acordos de acionistas frente ao que já previa a redação original do art. 118, cristalizando o papel da companhia como gendarme $e^{151}$ das disposições estabelecidas entre os pactuantes.

Uma série de disposições foram assim incluídas no texto legal, que passou a contar com 11 parágrafos ${ }^{152}$. Algumas disposições (par. §8, §9) passaram a prever hipóteses de verdadeira autotutela dos acionistas pactuantes

${ }^{150}$ Cf. Carvalhosa, Comentários, cit., p. 518.

${ }^{151}$ OpPo utiliza a expressão para criticar duramente a posição brasileira de conferir efeitos "extra-partes" ao acordo de acionistas, ainda ao tempo da vigência do texto original do art. 118 ("non si può fare della società il gendarme del rispetto di accordi fatti alle sue spalle". Le convenzioni..., cit. p.530).

$152 \S 6^{\circ}$ O acordo de acionistas cujo prazo for fixado em função de termo ou condição resolutiva somente pode ser denunciado segundo suas estipulações. (Incluído pela Lei $\mathrm{n}^{\circ}$ 10.303 , de 2001) § $7^{\circ}$ O mandato outorgado nos termos de acordo de acionistas para proferir, em assembléia-geral ou especial, voto contra ou a favor de determinada deliberação, poderá prever prazo superior ao constante do $\S 1^{\text {o }}$ do art. 126 desta Lei.(Incluído pela Lei $n^{\circ} 10.303$, de 2001) $\$ 8^{-}$O presidente da assembléia ou do órgão colegiado de deliberação da companhia não computará o voto proferido com infração de acordo de acionistas devidamente arquivado. (Incluído pela Lei $n^{\circ} 10.303$, de 2001) $\S 9$ o $\mathrm{O}$ não comparecimento à assembléia ou às reuniões dos órgãos de administração da companhia, bem como as abstenções de voto de qualquer parte de acordo de acionistas ou de membros do conselho de administração eleitos nos termos de acordo de acionistas, assegura à parte prejudicada o direito de votar com as ações pertencentes ao acionista ausente ou omisso e, no caso de membro do conselho de administração, pelo conselheiro eleito com os votos da parte prejudicada.(Incluído pela Lei $n^{\circ} 10.303$, de 2001) § 10. Os acionistas vinculados a acordo de acionistas deverão indicar, no ato de arquivamento, representante para comunicar-se com a companhia, para prestar ou receber informações, quando solicitadas. (Incluído pela Lei $n^{\circ} 10.303$, de 2001) § 11. A companhia poderá solicitar aos membros do acordo esclarecimento sobre suas cláusulas.(Incluído pela Lei $\mathrm{n}^{\circ}$ 10.303, de 2001) 
frente àquele inadimplente, com relação aos acordos de voto ${ }^{153}$. Outras procuraram dar fim a discussões doutrinárias (§6) e organizar o modo de administração do acordo junto da companhia $(\S 7, \S 10, \S 11)$.

Não se aproveitou a oportunidade, porém, para introduzir modificações na redação original do texto que esclarecessem os principais pontos controversos a respeito dos pactos parassociais ou mesmo para oferecer-lhes disciplina geral e mais detalhada, sob a perspectiva societária.

\subsection{5- Pactos parassociais e disciplina do Código Civil 2002}

Será explorado, adiante, o tema dos limites de aplicação do artigo 118 da Lei 6.404/76.

Uma das principais limitações discutidas pela doutrina, antecipa-se desde já, refere-se ao fato de somente ser possível dotar contratos parassociais dos efeitos previstos na lei 6.404/76 se realmente se tratar de acordos de acionistas. Com relação a execução específica, ulteriores comentários serão realizados no Capítulo 3.

Dessa maneira, escapariam à disciplina da lei 6.404/76 acordos celebrados com vistas aos demais tipos societários, ainda que tendo por objeto as matérias indicadas no art. 118. Com relação a eles - e em especial à sociedade limitada - é necessário, portanto, analisar o que, a respeito, prevê o Código Civil Brasileiro ${ }^{154}$.

\footnotetext{
${ }^{153}$ Sobre o tema cf. Daniel Moreira do Patrocínio, Autotutela do Acordo de Acionistas Novo regime estabelecido pela Lei 10.303/2001, in RDM 135, Julho-setembro/2004, pp. 194-205; Viviane MÜller Prado, Aplicação imediata da nova disciplina sobre acordo de acionistas, in Revista de Direito Bancário do Mercado de Capitais e da Arbitragem n. ${ }^{\circ} 17$, ano 5 - julho-setembro de 2002, pp. 262-268.

${ }^{154}$ A necessidade de exame dos acordos de cotistas é enfatizada por ERICK Corvo, ao comentar que "o acordo de sócios de sociedade limitada permanece objeto de discussóes (ou supostas discussões), notadamente no que se refere à sua licitude, validade, eficácia perante a sociedade e terceiros e, principalmente, a sua vinculação à disciplina legal do acordo de acionistas. Acordos de sócios de sociedades limitadas à luz do Código Civil de 2002 in AAVV, Temas de Direito Societário e Empresarial Contemporâneos - Liber
} 
Gestado desde os anos 70 e finalmente promulgado em 2002, o Código Civil Brasileiro operou a unificação do regramento das obrigações no Brasil e reuniu a disciplina societária antes constante do Código Comercial de 1850 e do Decreto 3708 de 1919, que regulava singularmente a sociedade limitada, no título Do Direito de Empresa.

Em que pese toda a discussão e cuidado em sua elaboração, os quase trinta anos que separaram o anteprojeto da entrada em vigor do diploma fizeram com que muitas posições assumidas pelo legislador não se mostrassem, afinal, compatíveis com a realidade a ser disciplinada.

Um dos aspectos mais controversos no novo código é, precisamente, a disciplina das sociedades comerciais. Sem considerar toda a construção jurisprudencial verificada nos anos de tramitação, o texto final acabou por representar verdadeiro retrocesso em muitos pontos.

Sem muito delongar na discussão, importa dizer que a sociedade limitada, antes tida como tipo societário flexível, que bem atendia às mais variadas necessidades práticas com o amparo de consistentes correntes jurisprudenciais, teve seu regime radicalmente alterado.

De fato, o enrijecimento das regras legais aplicáveis (como quorum elevado para deliberações, por exemplo), não condizentes com o estágio de desenvolvimento do instituto, retirou-lhe muito de seu atrativo.

Curiosamente, porém, o Código não forneceu às sociedades limitadas dispositivo legal específico sobre a contratação parassocial, na esteira do que, com relação às sociedades anônimas, a lei de 1976 realizou.

Ao contrário, manteve-se na linha do antigo Código Comercial de 1850 no sentido de condenar contratos que contrariem o disposto no contrato social, gerando semelhante insegurança.

Amicorum Prof. Dr. Erasmo Valladão Azevedo e Novaes França, São Paulo, Malheiros, 2011, p.84. 
Ocorre que ao invés de decretar a nulidade de referidos contratos, a lei determinou que "é ineficaz em relação a terceiros qualquer pacto separado, contrário ao disposto no instrumento do contrato" ${ }^{155}$, o que não reduziu as dificuldades e insegurança na celebração de acordos de cotistas.

De outro lado, o tema da aplicação subsidiária da Lei das Sociedades Anônimas às sociedades limitadas, já de certa forma pacificado no direito anterior, recebeu tratamento bizantino ${ }^{156}$.

De qualquer maneira, o entendimento predominante é o de que o artigo 118 da Lei de Sociedades Anônimas não se aplica subsidiariamente a contratos parassociais de outros tipos societários ou seja, esses outros contratos não têm o condão de produzir os efeitos legais de que são dotados os acordos de acionistas ${ }^{157}$.

Não havendo a intenção de produzir os efeitos específicos do art. 118 da Lei de Sociedades Anônimas, contudo, os acordos de cotistas (como de resto todos os contratos parassociais) seriam em princípio válidos e vinculantes entre as partes contratantes. Entretanto, mesmo essa evidente constatação, por vezes, encontra dificuldades em sua compreensão e aceitação.

\section{3 - Notas de comparação legislativa}

Não se busca, na presente tese, realizar completo estudo de Direito Comparado sobre o tema dos contratos parassociais, o que exigiria a análise

\footnotetext{
155 Art. 997, parágrafo primeiro.

${ }^{156}$ Tornou-se comum usar essa expressão para qualificar o complexo, prolixo e escalonado sistema de referências cruzadas e aplicação subsidiária no Código Civil. Para o assunto, cf. PAUla A. Forgioni, A unicidade do regramento jurídico das sociedades limitadas e o Art. 1.053 do Código Civil - Usos e costumes e regência supletiva in AAVV, Temas de Direito Societário e Empresarial Contemporâneos - Liber Amicorum Prof. Dr. Erasmo Valladão Azevedo e Novaes França, São Paulo, Malheiros, 2011, pp. 216-223.

157 Ver-se-á que, com relação à execução específica, essa circustância pouco altera o regime aplicável, pois segundo a legislação processual em vigor, todo contrato pode ter execução específica, se observados os requisitos nela enunciados.
} 
aprofundada dos institutos a ele afeitos nos diversos ordementos jurídicos ${ }^{158}$. Contudo, entendeu-se relevante trazer a notícia da legislação estrangeira para evidenciar a ausência, em geral, de regramento abrangente a respeito desse grupo de contratos, que pudesse oferecer indícios para a sua interpretação.

\subsection{1 - Breve notícia das legislações da Europa Continental}

Desde os anos oitenta, discute-se na Europa o texto de uma diretiva sobre direito societário, tratando sobre a estrutura de sociedades e poderes de seus órgãos (Quinta Diretiva, proposta inicialmente em 19.08.1983) ainda não aprovada, que prevê artigo sobre a disciplina de pactos parassociais ${ }^{159}$.

O legislador português de 1986 adotou o texto originalmente proposto para a Quinta Diretiva européia ${ }^{160}$, incluindo-o como artigo 17 de seu Código de Sociedades Comerciais ${ }^{161}$. Ao fazê-lo, não conferiu aos contratos

158 A respeito dos esforços comparatísticos, vale conferir a obra coletiva organizada por Franco Bonelli e Pier Giusto Jaeger (Sindacati di Voto. Sindacati di Blocco, Milano, Giuffré, 1993) e, entre nós, a síntese de Celso BARBI Filho, Acordo de Acionistas: panorama atual..., cit. pp. 32-34.

${ }^{159} \mathrm{Cf}$. Terceira modificação à proposta de quinta directiva do Conselho baseada no artigo $54^{\circ}$ do Tratado CEE, relativa à estrutura das sociedades anónimas e aos poderes e obrigações dos seus órgãos, apresentada em 12/12/91. Disponível em http://eurlex.europa.eu/LexUriServ/LexUriServ.do?uri=OJ:C:1991:321:0009:0012:PT:PDF Menezes Cordeiro, Manual... cit., p. 575.

${ }^{160}$ Cf. Menezes Cordeiro, Acordos parassociais, cit., p. 339.

${ }^{161}$ Artigo 17. ${ }^{\circ}$ Acordos parassociais - 1 - Os acordos parassociais celebrados entre todos ou entre alguns sócios pelos quais estes, nessa qualidade, se obriguem a uma conduta não proibida por lei têm efeitos entre os intervenientes, mas com base neles não podem ser impugnados actos da sociedade ou dos sócios para com a sociedade. 2 - Os acordos referidos no número anterior podem respeitar ao exercício do direito de voto, mas não à conduta de intervenientes ou de outras pessoas no exercício de funções de administração ou de fiscalização. 3 - São nulos os acordos pelos quais um sócio se obriga a votar: a) Seguindo sempre as instruções da sociedade ou de um dos seus órgãos; b) Aprovando sempre as propostas feitas por estes; c) Exercendo o direito de voto ou abstendo-se de o exercer em contrapartida de vantagens especiais. 
parassociais os efeitos que no Brasil são produzidos pelos acordos de $\operatorname{acionistas}^{162}$.

$\mathrm{Na}$ Alemanha, a Lei de Sociedades por Ações (AktG) apresenta dispositivos sobre a proibição de voto exercido seguindo-se instruções da sociedade ou de seus administradores (§ 136) e o comércio de voto (§405). Na doutrina, o tema também é tratado pelos comentaristas da lei nos comentários ao $\$ 23$, relativo à elaboração do Estatuto Social ("Feststellung der Satzung"), tendo em vista que a alínea 5 prevê a validade para as disposições complementares ("Ergänzende Bestimmungen”) que não contrariem o disposto em lei. No direito alemão é mais frequente a celebração de acordos parassociais (designados Nebenverträge ou Nebenabreden) nas sociedades limitadas, não existindo disposição específica, contudo, na lei que as rege (GmbHG). Também neste caso, a doutrina toca o tema dos pactos parassociais ao comentar o $\$ 3$ da lei, no âmbito da autonomia na celebração de ajustes que excedam o conteúdo previsto, no mesmo artigo, para o contrato social ("Inhalt des Gesellschaftsvertrags") ${ }^{163}$.

A Itália incluiu no Codice Civile disciplina específica sobre contratos parassociais apenas em 2003 (art. 2341-bis e 2341-ter) ${ }^{164}$. Todavia, havia

\footnotetext{
${ }^{162}$ Cf. Ana Felipa LeAl, Algumas notas sobre a parassocialiadidade no direito português, in Revista de Direito das Sociedades, 1, 2009, pp. 135-183 e Raul Ventura, Acordos de voto: algumas questões depois do Código das Sociedades Comerciais (CSC, art. 17 ${ }^{\circ}$ ), in Estudos vários sobre sociedades anônimas: comentários ao Código das Sociedades Comerciais, Coimbra, Almedina, 1992, pp. 7-101. O pioneiro artigo publicado naquele país foi da lavra de FERnANDo Galvão Telles, União de contratos e contratos para-sociais, in Revista da Ordem dos Advogados Portugueses 1-2, jan.-jun, 1951, pp. 37-103.

163 Cf. Cláudio Köhler, Nebenabreden im GmbH- und Aktienrecht - Zulässigkeit und Wirkung, Frankfurt am Main, Peter Lang, 1992, pp. 3-7.

${ }^{164}$ Art 2341 bis - I patti, in qualunque forma stipulati, che al fine di stabilizzare gli assetti proprietari o il governo della società: a) hanno per oggetto l'esercizio del diritto di voto nelle società per azioni o nelle società che le controllano; b) pongono limiti al trasferimento delle relative azioni o delle partecipazioni in società che le controllano; c) hanno per oggetto o per effetto l'esercizio anche congiunto di un'influenza dominante su tali società, non possono avere durata superiore a cinque anni e si intendono stipulati per questa durata anche se le parti hanno previsto un termine maggiore; i patti sono rinnovabili alla scadenza. Qualora il patto non preveda un termine di durata, ciascun contraente ha diritto di recedere con un preavviso di centottanta giorni. Le disposizioni di questo articolo non si applicano ai patti strumentali ad accordi di collaborazione nella produzione
} 
previsão sobre a duração de "sindacati di blocco" relativos a sociedades de capital aberto no decreto legislativo de n. 58 de 24.2.1998 (Testo Unico della Finanza), em parte aproveitada na redação incluída no Codice Civile ${ }^{165}$.

$\mathrm{Na}$ França, ordenamento mais refratário à aceitação dos acordos de voto, o tema dos pactos parassociais não conta com disposição única na legislação, sendo referido em dispositivos de diversas leis, sobretudo relativas ao mercado de capitais ${ }^{166}$. A lei de 1999 que implementou as sociedades por ações simplificadas ("SAS") permitiu maior flexibilidade de redação dos estatutos, sem tratar especificamente, porém, dos pactos parassociais.

A Espanha, já admitia os acordos de voto enquanto vigente a lei de sociedades anônimas de 1951. O art. $6^{\circ}$ de referida Lei prescrevia que os pactos firmados entre os sócios, mantidos ocultos, não seriam oponíveis à sociedade. Essa disposição foi mantida pelo art. 7.1 da Lei de Sociedades Anônimas (Decreto 1564/1989): "Los pactos que se mantengan reservados entre los socios no serán oponibles a la sociedade”.

Em julho de 2010, entretanto, a disciplina foi alterada justamente para incluir disposição relativa à transparência dos acordos, atualizando a questão frente às sempre mais rígidas regras de corporate governance. Para exigências de publicidade previstas na lei, o legislador espanhol restringiu a noção de pactos parassociais para "aquellos pactos que incluyan la regulación del ejercicio del derecho de voto en las juntas generales o que restrinjan o

o nello scambio di beni o servizi e relativi a società interamente possedute dai partecipanti all'accordo.

165 Cf. Raffale Torino Sindacati di blocco in i nuovi contratti nella prassi civile e commerciale, a cura di Paolo Cendon, vol. XXII, p. 36.

${ }^{166}$ Para elenco das disposições relativas ao tema, cf. Ripert e Roblot, Michel Germain (atual.) Traité de Droit Comercial, $18^{\mathrm{a} e d .}$ Tomo 1, Vol.2, Paris, LGDJ, 2003, p. 399. Nas páginas 239-241, verifica-se a crítica sobre as imperfeições da lei de 1966, que alterou as disposições constantes do Code de Commerce sobre as sociedades e a proliferação legislativa posterior. GUYON esclarece que as diversas referências legais a pactos parassociais não se referem a seus limites de validade, mas a temas como contas consolidadas, definição de controle majoritário e de ação de concerto (Les sociétés... cit., p. 309). 
condicionen la libre transmisibilidad de las acciones en las sociedades anónimas cotizadas ${ }^{167}$

Em suma: nas legislações européias consultadas o tratamento dos contratos parassociais é pontual, deixando em aberto, para o intérprete e aplicador do direito, um vasto campo de atuação e a tarefa de determinar $o s$ limites de validade de contratos parassociais ${ }^{168}$.

Talvez seja justamente essa a causa da proliferação dos contratos parassociais ou, para usar a terminologia francesa, do movimento de contractualisation $d u$ droit des sociétés: a aparente ampla liberdade que a legislação confere, quando se toma a regra geral do direito privado de que "o que a lei não veda está permitido" 169 .

Esse entendimento, contudo, parece equivocado, como se procurará demonstrar no Capítulo 4.

\subsection{2 - Peculiaridades do direito da common law}

Nos países alinhados à common law, algumas peculiaridades impactam o tema dos pactos parassociais, quando confrontados aos regimes previstos nos direitos continentais.

\footnotetext{
${ }^{167}$ Atual art. 518 da Lei de Sociedades Anônimas.

168 GUYON esclarece que, cada vez mais, as legislações mencionam a existência desses acordos sem, entretanto, precisar suas condições de validade ou orientar sua interpretação, deixando aos tribunais decidir ("Mais la loi ne précise pas les conditions de validité de ces conventions. On peut seulement tirer de cette référence l'idée que de tels accords ne son pas toujours nuls. Mais il appartiene aux tribunaux de décider quand ils sont valables". Les sociétés, cit, p. 309).

169 Celso Barbi Filho diz mesmo que: “[a] experiência do direito estrangeiro mostra que, em face das características peculiares do acordo de acionistas, sua previsão e disciplina em lei trazem mais dificuldades do que soluções. Enquanto negócio jurídico, ele deve existir e ser aplicado dentro do princípio de direito privado segundo o qual é permitido tudo aquilo que a lei não proíbe" (Acordo..., cit., p. 38. Grifou-se). Em outro ensaio, contudo, o autor esclarece, em verdade, que a ausência de disciplina expressa apenas faz com que a aferição da licitude se dê a posteriori ("esses países, em sua maioria, não cuidam de uma disciplina legal dos acordos de acionistas, admitindo sua celebração à luz do direito obrigacional comum e deixando a aferição de sua licitude para os casos concretos, em que se repele o uso do instituto para venda de voto ou alijamento de minorias". Acordo de Acionistas: panorama atual..., cit., p.34).
} 
Com relação ao direito inglês, o próprio âmbio de abrangência da lei, nas relações privadas é muito reduzido, quando comparado ao direito de matriz romano-germânica, razão pela qual inexiste disciplina legal dos acordos celebrados entre acionistas ${ }^{170}$.

O regime desses contratos, por consquência, é modelado pelos precedentes e, principalmente, pela contribuição da prática. Como o respeito ao contratado goza de prestígio ímpar, a tendência da jurisprudência é a de preservar, ao máximo, o que as partes tiverem validamente contratado ${ }^{171}$ : em caso de litígio pouco espaço é deixado ao juiz, que deve interpretar e aplicar o contrato respeitando a vontade das partes manifestada no documento, assegurando o que fora estabelecido entre elas.

Nesse cenário, os contratos entre acionistas florescem, adaptando aos seus interesses as regras legais cogentes, voltadas principalmente à organização das sociedades. Por permitirem aos particulares possibilidade submeterem-se a regramento mais próximo de sua real intenção comum, os ajustes entre sócios são reconhecidos e tipos por salutares.

Consequência peculiar dessas ponderações é que, com certa tranqüilidade impensável nos países da tradição romano-germânica, admite-se que os pactos parassociais prevaleçam sobre os estatutos sociais seguindo a

\footnotetext{
${ }^{170}$ LAURent Convert, anota, comparando sistemas de common law e civil law, que "a força vinculante das práticas contratuais são assaz diferentes de um lado e de outro do Canal da Mancha. O costume britânico requer que o legislador não intervenha nas relações entre as pessoas, não sendo de sua competência a menos que haja abuso, enquanto na tradição latina o órgão legislativo é diretamente envolvido para a determinação das condições que envolvem as relações contratuais. As partes dispõem por conseqüência de uma liberdade mais ampla na Inglaterra para determinar o imperativo que se imporá a elas (doutrina da freedom of contract), e o contrato constitui no essencial a lei que lhes será aplicável" ("La place et la force contraignante des pratiques contractuelles sont ainsi diferentes d'un côté et de l'autre de la Manche. La coutume britannique veut que le législateur n'intervienne pas dans les relations entre personnes, qui ne sont de sa compétance que s'il y a abus, alors que dans la tradition latine, l'organe législatif est directement concerné par la détermination des conditions encadrant les relations contractuelles. Les parties jouiront en consequence d'une liberté plus grande en Angleterre pour determiner l'imperátif qui s'imposera à eles (doctrine of freedom of contract), le contract constituant pour l'essentiel la loi qui leur sera applicable". L'impératif... cit., p. 206).
}

${ }^{171}$ Cf. Laurent Convert, L'imperatif... cit., p. 495 e ss.. 
regra de que o especial derroga o geral e tendo por base a noção de que acordos são feitos para melhorar a situação jurídica das sociedades privadas ${ }^{172}$.

CONVERT noticia, ainda, que um dos principais debates na comunidade jurídica britânica refere-se à possibilidade de acordos privados derrogarem os direitos previstos legalmente para os acionistas: na tradição de respeito à autonomia privada, muitos advogam que essa possibilidade seria justificada quando os direitos renunciados dizem respeito a interesses privados dos acionistas, sem qualquer relevância para interesse público ${ }^{173}$.

Nos Estados Unidos a legislação societária é, fundamentalmente, de competência estatal e não federal, como ocorre no Brasil. ${ }^{174}{ }^{175}$. De outro lado, seguindo a característica do sistema de Common Law, a intervenção estatal, por meio de leis é quase incipiente e, por consequência, os contornos dos institutos são moldados, no essencial, pela prática e pela evolução jurisprudencial ${ }^{176}$.

${ }^{172}$ Idem, pp. 202-203. Nessa linha também aponta CELSO BARBI FILho: “[n]a Inglaterra, país da common law, o instituto não só foi sempre aceito como muito utilizado e desenvolvido na vida empresarial. Há naquele país o voting agreement, figura contratual cuja força vinculante a jurisprudência tem reconhecido como superior aos próprios estatutos sociais (Acordo de acionistas: panorama... cit., p. 33-34).

${ }^{173}$ L'imperatif... cit., p. 204.

174 Cf. Thomas Joyce, Shareholder Agreements: A U.S. Perspective, in PIER GIUSTO Jaeger e Franco Bonelli (coord.), Sindacati di voto e sindacati di blocco, Milano, Giuffrè, 1993, p. 355.

175 “Nos EUA as sociedades anônimas são objeto de leis específicas nos diversos Estados. Essas leis, em regra, limitam-se a disciplinar a constituição da sociedade e seus aspectos funcionais, nada dispondo sobre os acordos de acionistas. Todavia, lá as convenções de voto e bloqueio são amplamente utilizadas e aceitas, a menos que tenham fins ilícitos ou visem a alijar minorias. Assim em tais convençõe as formas do pooling agreement, de caráter contratual e destinado a organizar grupos de controle. Já os shareholders'agreements objetivam regular a eleição de administradores. E há ainda a figura do voting trust, modelo corporativo de representação de minorias nas grandes companhias, caracterizando uma forma mais aberta do sindicato de voto europeu. Prestigiase no Direito Norte-Americano a plena eficácia dos acordos de acionistas, por meio da mandatory injunction, ordem do juiz dada diretamente à parte para que cumpra o pactuado" (Celso B ARBi Filho, Acordo de acionistas: panorama..., cit., p.34).

${ }^{176}$ Nesse sentido, cf. a análise que JOYCE ThOMAS faz ao analisar a legislação do Estado de Delaware como paradigma dos regramentos estaduais americanos (Shareholder Agreements... cit.). 
As peculiaridades acima evidenciadas fornecem elementos para compreender o cenário em que se desenvolvem tão intensamente os shareholders' agreements: eles serão, efetivamente, o instrumento que reunirá as disposições com que os acionistas signatários, voluntariamente, modelaram seu relacionamento.

É por esse viés que o tema dos shareholders' agreements (i.e., contratos entre acionistas) é analisado, e não sob a ótica tão cara à doutrina dos países de civil law, de sua ligação com o contrato ou estatuto social (evidenciada nas expressões parassocial ou extra-estatutário).

\section{4 - Conclusão e reflexões sobre o panorama atual}

Atualmente, a utilização de contratos parassociais - "acordos de acionistas" ou não - é intensa e generalizada na prática societária brasileira e estrangeira.

Um dos fatores que, de resto, influencia não apenas o Brasil, mas também os ordenamentos jurídicos de países em que há alto grau de internacionalização da economia é a força da produção de modelos contratuais e de negócios proveniente dos Estados Unidos (a chamada "americanização" do direito).

Se de um lado o direito norte-americano é pródigo em lançar ao mundo modelos contratuais, a mesma intensidade de produção não se encontra com relação a estudos acadêmicos relativos aos pactos parassociais, o que deriva da própria concepção de companhia e de liberdade contratual vigente nos diversos estados que compõem aquela nação.

Mais além, é preciso observar que a própria concepção do direito societário e seus objetivos, seu tratamento doutrinário e legal diferem muito entre os países de tradição anglo-saxônica e aqueles filiados de linhagem romano-germânica, o que pode explicar esse aparente paradoxo. 
Já desde os anos 90, vive-se acentuação no fenômeno da contratação parassocial em todo o mundo, com volume sempre maior de obras e autores, sobretudo na Europa, a cuidar do assunto ${ }^{177}$.

As operações econômicas transacionais moldadas no modelo das joint ventures, de um lado, e os investimentos realizados pelos fundos de private equity de outro ${ }^{178}$, elevam sobremaneira o número de contratos parassociais e os dotam de sempre novas funções e objetivos, no interesse das partes contratantes dos mais diversos negócios: a existência de contratos parassociais pode mesmo ser indicada como um traço característico, do ponto de vista de estruturação jurídica, dessas operações.

Além disso, os contratos parassociais, sempre multiformes, podem ser encontrados nas mais diversas operações econômicas.

\footnotetext{
177 EDgar Joussen comenta que "o contrato ou estatuto social configura as bases da sociedade de acordo com o que a lei prevê. Na prática mostra-se sempre mais que os sócios regulam, em outros contratos paralelos ao contrato ou estatuto social, variados e importantes aspectos fundamentais e de relevância para a sociedade. Isso vale para todos os tipos de sociedade, mas principalmente para as sociedades de capital. O significado desse tipo de contratos, assim, não é de se subestimar. Contudo a doutrina a respeito é apenas esparsa. (in verbis: "Nach dem Gesetzt bildet der Gesellschaftsvertrag die Grundlage einer Gesellschaft. In der Praxis zeigt sich jedoch zunehmend, da $\beta$ Gesellschafter vielfach wichtige und für die Gesellschaft bedeutende Grundsentscheidungen neben dem Gesellschaftsvertrag in eigenen schuldrechtlichen Verträge regeln. Das gilt für alle Gesellschaftstypen, vor allem für Kapitalgesellschaften. Die Bedeutung derartiger Verträge im Wirtschaftsleben ist kaum zu überschätzen. Gleichwohl ist das diesbezügliche Schriftum nur spärlich". Gesellschafterabsprachen neben Satzung und Gesellschaftsvertrag, Köln, Otto Schimidt, 1995, p. V).

178 Como já se mencionou os ajustes parassociais são elementos fundamentais na estrutração de operações de capital de risco pelos fundos de venture capital e private equity. A evolução do fenômeno da contratação parassocial, sua crescente sofisticação e sua difusão generalizada são intrinsicamente ligadas ao crescente volume de operações desse gênero nos mais diversos países. DAIGRE e SANTILles-Dupont reforçam, ainda, a influência das práticas americanas como determinantes desse processo: ("[d]e même, le développement des opérations de capital-risque a été l'occasion de l'utilisation et de la création d'une multiplicité de pactes, parfois trés complexes. L'accelération des transmissions d'entreprises, em particulier des transmissions intrafamiliares de PME-PMI a suscité la florirason de très nombreux protocoles" e "l'influence des pratiques angloaméricaines a souvent été determinante". Pactes... cit., pp.2-3). De fato, o tema dos pactos parassociais é impactado diretamente pelas práticas contratuais diuturnamente talhadas nos escritórios de advocacia americanos cujos "modelos" rapidamente atingem as mais diversas realidades jurídicas.
} 
São encontrados na estruturação prévia e gestação de operações no mercado de capitais (como lançamento inicial de ações ou ofertas públicas de aquisição), ou mesmo na preservação de interesses em virtude dessas mesmas operações; na consolidação de grupos de poder com a criação de estruturas piramidais; na fixação de remuneração de administradores, na previsão de mecanismos de saída de sociedades etc.

Como se apontou na Introdução, a doutrina francesa frequentemente utiliza a expressão ingégnierie financiére para agrupar alguns dos aspectos ligados aos temas acima indicados, para os quais os aplicadores do direito vêm utilizando os variados arranjos contratuais para atingir o resultado desejado.

Tudo isso, enfim, compõe o cenário em que se desenvolverá o presente estudo. 


\section{2 - CARACTERIZAÇÃO DOS PACTOS PARASSOCIAIS PATRIMONIAIS: FUNÇÃO ECONÔMICA}

\section{1 - Pactos parassociais patrimoniais: função econômica}

Retomando o que se disse na Introdução, pouco se enfatiza, na doutrina societária, que o termo "sociedade" refere-se tanto ao relacionamento societário fundado na cooperação (ou aos comportamentos societários, que autores alemães designam por Gesellschaftsverhältnisse) quanto à pessoa jurídica, à organização gerada por esse mesmo relacionamento (a "Verband $\left.{ }^{179 ")}\right)^{180}$.

O direito societário tem por objeto, por consequência, ambas as facetas do fenômeno e essa percepção é crucial para bem compreender os pactos parassociais em sua função econômica: eles formatam o relacionamento societário entre as partes, independentemente de produzirem, necessariamente, efeitos sobre a organização da pessoa jurídica, da sociedade ${ }^{181}$.

$\mathrm{Na}$ Introdução, apontou-se preliminarmente como função econômica dos pactos parassociais, em geral, integrar, detalhar e personalizar a disciplina do relacionamento societário existente entre as partes, regulando o exercício

\footnotetext{
${ }^{179}$ No entender de Otto Carlos Vieira Ritter von AdameK, baseado em Wiedemann, “a palavra Verband tem sentido plurívoco em alemão, em sentido estrito, designa as associações que perseguem fins políticos e exercem influência social (...); em sentido lado, abrange as associações propriamente ditas e as sociedades" (tradução para o português do artigo de autoria de HERBERT WIEDEMANn, Vínculos de lealdade e regra de substancialidade in AAVV, Temas de Direito Societário e Empresarial Contemporâneos. Liber Amicorum Prof. Dr. Erasmo Valladão Azevedo e Novaes França, Malheiros, São Paulo, 2011,p. 145, nota 5.).

${ }^{180}$ Voltar-se-á ao tema no Capítulo 4.

${ }^{181}$ Sobre a dualidade do fenômeno societário, cf. KARSTEn SCHMIDT, Gesellschaftsrecht, cit., p. 3 e ss e Menezes Cordeiro, Manual ..., cit. p. 24.
} 
de direitos de sócio ${ }^{182}{ }_{-}^{183}$, já se tendo afirmado, com relação aos ajustes centrados em direitos políticos, que é quase imediato o reconhecimento de sua função integradora do regime a que os sócios desejam se submeter, tendo em vista sua associação societária ${ }^{184}$.

Com relação aos pactos parassociais que envolvem direitos patrimoniais (e não políticos) dos sócios, essa função é peculiar e não diretamente percebida.

É forçoso reconhecer, contudo, que as partes também os celebram com vistas a complementar e detalhar aspectos de seu relacionamento, fazendo-os integrar o regramento de sua convivência societária. A peculiaridade, aqui, repousa em fazê-lo não com base no exercício do direito de voto para modelar a estrutura e funcionamento da sociedade, mas atribuindo essa função integradora ao manejo de direitos individuais do sócio frente aos demais.

Tome-se como exemplo por excelência dos pactos parassociais patrimoniais os ajustes de compra e venda de participações: ao contrário do que se pode aventar à primeira vista, eles atendem à necessidade de regulação

\footnotetext{
182 Cf. Daigre e SAntilles-Dupont (“ce qui fait l'originalité de ces accords, c'est moins leur forme, l'acte global structuré dans lequel ils s'insèrent, que leur finalité: ils sont destinés à infléchir ou à compléter les clauses habituelles des statuts" Pactes d'actionnaires, cit, p. 2. Grifou-se). Ainda aqui, todavia, os autores se voltam à integração do estatuto, quando a ótica ora proposta tem em mira a completa disciplina do relacionamento societário.

${ }^{183}$ Tendo em vista a relevância da noção de função econômica dos contratos parassociais patrimoniais para os argumentos desenvolvidos nesta tese, convém deixar assentado, com base em ORLANDO GOMES, que “a função econômica e social de um contrato é proporcionar às partes o meio lícito para alcançar fim tutelado pelo ordenamento jurídico". (Transformações Gerais do Direito das Obrigações, RT, São Paulo, 1980, p.76).

${ }^{184}$ Vale transcrever a clara lição de CRISTINA CERONi, em que ressalta, com base em OPPO, ser típico dos contratos parassociais integrar o regulamento societário com norma paralela desejada pelas partes, e que o intenso emprego desses contratos desmente que tenham pouca influência no fenômeno societário ("[i]n realtà è tipico invece della struttura negoziale dei patti parasociali integrare il regolamento societario con una normativa parallela, non solo volutamente estensiva ma, a volte, ed è quello che più conta, volutamente difforme dagli impegni dello statuto o dell'atto costitutivo, a conferma che l'attuale, massiccio impiego di queste convenzioni private, sembra così smentire la corrente scarsa influenza loro attribuita nei confronti del fenomeno societario". Simulazione..., cit., p. 1118).
} 
e solução de aspectos cruciais para o relacionamento societário e não apenas à alteração patrimonial das partes.

De fato, ao determinar condições de desconstituição do vínculo entre sócios e fornecer-lhes alternativa diante de situações extremas (como nos casos de impasse decisório e/ou alienação de lote majoritário de ações a terceiros - tag along right) entre outras aplicações, esses ajustes formatam, de maneira evidente, a relação entre os sócios. São, portanto, parte indissociável da dinâmica existente entre eles: encontram-se completamente imersos na relação societária ${ }^{185}$.

Em suma, os pactos parassociais patrimoniais contribuem, de forma singular, para a configuração do regime global que deve valer entre os sócios, sendo entabulados justamente sob essa ótica e com essa finalidade. Nesse sentido, os pactos parassociais (patrimoniais ou não) informam a caracterização do estado de sócio ${ }^{186}$. Vale transcrever na íntegra, aqui, a lição de Menezes Cordeiro:

"[r]ecordamos que o estado das pessoas pode ser entendido numa de três acepções: - o estado-qualidade, correspondente a uma determinada posição da pessoa; - o estado como complexo de situações jurídicas correspondentes a essa qualidade ou por ela potenciadas ou condicionadas; - o estado enquanto complexo de normas jurídicas reguladoras dessa massa de situações. As referidas acepções estão inter-ligadas. Parte-se do estadoqualidade, decorrendo, dele, as outras duas acepções. Pois bem: ao admitir o "estado de sócio", podemos exprimir, de modo sintético, todo um mutável mas consistente conjunto de posições

185 Cf. Junqueira DE AZEvedo, ao examinar caso concreto envolvendo pacto parassocial relativo a opção de venda de ações, com propriedade assevera que "[o] contrato de opção de venda de ações (...) possui relação com os demais negócios celebrados entre as partes, notadamente com o acordo de acionistas da Companhia, celebrado na mesma data e entre as mesmas partes. Ambos têm natureza parassocial, isto é, se colocam ao lado do contrato social e se destinam a integrar e complementar a relação entre os sócios da sociedade" (Novos Ensaios... cit., p. 245. Grifou-se).

${ }^{186}$ A obra de Géraldine GoffauX-Callebaut também parte desse ponto de vista, como se depreende do Prefácio de JEAN-PIERRE GASTAUD: [1]es pactes extra-statutaires qui a priori relèvent de la définition et du régime classique des contrats ont-ils pour fin d'aménager le statut d'associé" (Du contrat..., cit., Grifou-se). 
jurídicas que, por lei, pelo contrato de sociedade, por outros acordos (designadamente: os parassociais) e por deliberações societárias lhe possam advir" ${ }^{187-188 .}$

Quando não se capta devidamente essa função dos pactos parassociais patrimoniais, diga-se uma vez mais, acaba-se por erroneamente enxergá-los como negócios jurídicos a salvo do regramento do direito societário, quando o que ocorre em verdade não autoriza símile afirmação: os pactos parassociais patrimoniais mostram-se como elementos-chave na estruturação de relacionamentos societários e, portanto, devem ser observados e interpretados à luz do direito societário e seus princípios.

\subsection{1 - Variedade de pactos e função econômica específica}

Uma vez assentada a função econômica dos pactos parassociais patrimoniais como integradora da disciplina vigente entre os sócios e, por isso, inspiradora da dinâmica que entre eles deve ser observada, cumpre

\footnotetext{
${ }^{187}$ Manual..., cit. p. 506-507. Grifou-se.

188 Esclarecedora, também, a posição de BRUNETTI: "O conceito de status compreende uma série de relações coligadas e interdependentes formando um ordenamento específico; não corrisponde por isso a uma relação única e nem mesmo se adapta àquela de titularidade. É uma situação complexa ou, melhor, um complexo de relações conexas. (...) Assim, como se dá um status de família, de filho legítimo, de incapaz, de herdeiro, de falido, etc há um status de sócio." ("Il concetto di status comprende una serie di rapporti collegati e interdependenti formanti un apposito ordinamento; non corrisponde perciò a un rapporto singolo e neppure si adatta a quello di titolaritá. È una situazione complessa o, meglio, un complesso di situazioni connesse (...). Quindi, come si dà uno status di famiglia, di figlio legittimo, di incapace, di erede, di fallito, ecc., vi è uno status di socio e, quando l'appartenenza alla società è documentada da um titolo di credito, questo è attributivo di tale status" Trattato..., cit., p. 222). O autor comenta, ainda, as posições de outros autores como SALANDRA, que entende inexata a expressão, por considerar que a condição jurídica, no status, é igual a todos aqueles que a investem, enquanto o mesmo não ocorreria na sociedade, não aborda, contudo, a formação do estado de sócio pelas relações entre sócios. Cf. nota 31, acima, para a posição de ANíBAL SANCHEZ. Na doutrina alemã o vocábulo empregado é "Mitgliedschaft". Para o assunto, cf. KARSTEn SCHMIDT, tópico "Participação como relação jurídica e como direito subjetivo" - Die Mitgliedschaft als Rechtsverhältnis und als subjektives Recht, Gesellschaftsrecht, cit., pp 549-550. Para boa resenha sobre o assunto, v. também DANiela Ramos MARQues MARINo, O status socii in Erasmo Valladão Azevedo e Novaes França (coord.), Direito Societário Contemporâneo I, São Paulo, Quartier Latin, 2009, pp. 163-182.
} 
perpassar os principais registros dessa função, em vista dos ajustes parassociais patrimoniais mais comumente verificados na prática societária ${ }^{189}$.

Consoante já se afirmou, não é objeto dessa tese - diante da inconteste multiplicidade de ajustes parassociais que a prática societária acusa - a enunciação ou descrição exaustiva de cada uma das modalidades de pactos parassociais patrimoniais.

O exame realizado, ao contrário, tem por escopo realçar aqueles traços dos ajustes em análise que apoiam a tese de que devem ser interpretados valendo-se das regras e princípios societários. Adota-se, assim, corte metodológico que privilegia a visão panorâmica das modalidades de ajustes verificados em detrimento da profundidade no exame das características e questões típicas de cada um deles.

A doutrina tradicionalmente agrupa esses ajustes sob classificações diversas. Os acordos parassociais são, então, reunidos sob a locução de "acordos de bloqueio" - quando se procura sublinhar a possibilidade de, contratualmente, as partes garantirem a coesão do bloco acionário signatário do pacto, com a utilização de cláusulas de restrição da circulação de ações, nelas incluídas as diversas formas de estruturação de direitos de preferência, evitando, "bloqueando" eventual esvaziamento dos acordos de voto que tenham firmado.

\footnotetext{
${ }^{189}$ Para o desenvolvimento desse capítulo vale-se, sobretudo, das obras: STEDMAN E JONES, Shareholders'Agreements... cit., e DAIGRE e SANTILLES-DUPONT, Pactes... cit., que apresentam descrição dos acordos mais comumente verificados na prática, acompanhados de suas motivações. Com relação à obra de STEDMAN E JONES são os próprios autores que ressaltam a notável ausência de bibliografia na matéria: "the purpose of this book is to examine a subject which seems to receive less attention in the standard legal texts than it perhaps deserves. Shareholders'agreements are being used increasingly by legal practitioners as a tool to 'customise' a company's ownership and management structure to meet the specific objetives of their clients. As a result, they form the hub of many different types od transaction, but, because they are inextricably linked to a company's articles of association, cannot be considered in isolation" (Shareholders'Agreements... cit., p. ix).
} 
De outro lado, ganham a designação "acordos de defesa", quando o que se está em jogo é a utilização dessas mesmas cláusulas - unidas naturalmente a acordos de voto - com o objetivo de criar minoria organizada e coesa para fazer frente ao controlador ${ }^{190}{ }^{191}$.

Para os fins deste trabalho, contudo, essas classificações mostram apenas que diante de diversas motivações, as partes efetivamente lançam mão de quanto o mais possam para assegurar que o relacionamento societário de que fazem parte ostente as características desejadas e seja pautado pelas regras que entendem mais coincidentes com seus interesses. Nesse sentido, parecem não contribuir, per se, para a análise dos elementos que devem ser considerados no processo interpretativo dos pactos parassociais patrimoniais.

\section{2 - Pactos relativos à compra e venda de participação societária - aspectos gerais}

Ajustes parassociais fundados na compra e venda de participações servem cada vez mais a inúmeras finalidades no contexto de uma associação societária ${ }^{192}{ }^{193}$.

\footnotetext{
190 Segundo Peggy LARrieu, há autores na França que classificam ainda os pactos em função de sua natureza jurídica, enquanto outros preferem considerar o aspecto orgânico, contrapondo acordos ligados ao exercício de poder àqueles relativos ao capital ou mesmo apresentar divisão tripartite entre "pactos de gestão"; "pactos do acionariado" e "pactos de saída". A autora, a seu turno, divide os pactos com base na finalidade de cada pacto, em pactos de colaboração por um período mais ou menos longo de tempo e pactos de resistência, com vistas à proteção dos signatários frente a ataques de terceiros ou mesmo dos próprios sócios (L'interprétation..., cit, p. 699).

${ }^{191} \mathrm{Na}$ doutrina italiana encontra-se a menção a sindacati finanziari que seriam aqueles contratos parassociais mediante os quais o sócio-financiador ou a instituição de crédito procura reduzir o risco relativo à futura revenda da participação societária (cf. LuCA Buttaro, Sindacati Azionari, cit. p. 426). Esses acordos - ver-se-á no Capítulo 4 - podem ter sua validade questionada, na medida em que possam estabelecer relação leonina entre as partes.

192 Muitas das reflexões aqui apresentadas encontram-se também em MARIANA Conti Craveiro, Aspectos Societários da Participação do Estado em Sociedades Anônimas, Dissertação de Mestrado, FDUSP. 2007, pp. 141-148 e no artigo Alguns aspectos jurídicos do desinvestimento nas operações de private equity in Aspectos do Mercado de Capitais, coord. Francisco Satiro de Souza Jr., Saraiva, no prelo. Quanto a este último, ainda não é possível indicar as páginas de que cada assertiva foi retirada.
} 
Em grande parte dos casos, elas se referem à necessidade de previsão de regras de saída, de modalidade de desfazimento do vínculo societário na ausência de regra legal ou mesmo de condições fáticas que o permitam de forma natural, sobretudo quando se leva em conta a baixa liquidez verificada quanto a ações de sociedades anônimas fechadas ${ }^{194}$.

De fato, é forçoso admitir que grande parte das sociedades anônimas fechadas não oferece condições concretas para que a saída se verifique de maneira satisfatória, ou seja, que o investimento encontre liquidez. Na maioria dos casos, os únicos interessados na aquisição de ações de companhias fechadas são os próprios acionistas que, havendo na associação forte caráter intuitus personae, são também titulares, usualmente, de direitos de preferência meticulosamente estruturados ${ }^{195}$

Considerando a necessária dilação do relacionamento societário no tempo ${ }^{196}$, as partes procuram precaver-se desde logo, utilizando os ajustes sobre compra e venda de participações para obter alternativas para findar sua associação ou minorar eventuais consequências da saída de um sócio ${ }^{197}{ }^{198}$.

193 Carlos Augusto Silveira Lobo propõe ao que designa acordos sobre ações uma classificação em: acordos de preferência, de promessa ou opção de compra ou venda, de consentimento prévio e de vedação à alienação (Acordo de Acionistas, in Direito das Companhias, (coord). Alfredo lamy Filho e José Luiz Bulhões Pedreira, Rio, Forense, 2009, vol. I, p. 465). Na presente análise, acrescentar-se-á os acordos de venda conjunta de participações.

194 Nesse sentido, "[s]hareholders of private companies are usually faced with restrictions on the transferability of their shares and with the absence of a market in those shares, especially if they are not in a controlling position. Not surprisingly, a person acquiring shares in a private company without obtaining control will be inclined to seek special protections and rights to safeguard this position" (STEDMAN E JONES, Shareholders'Agreements, cit., p. 1).

${ }^{195}$ Como já se comentou, as sociedades de pessoas e as limitadas oferecem a possibilidade de dissolução do vínculo societário de um dos sócios, mediante sua solicitação e com o pagamento de seus haveres, conforme o disposto nos Arts. 1.029 e 1.030 do Código Civil (MARIAnA CONTI CRAVEIRo, Alguns aspectos jurídicos..., cit.).

${ }^{196}$ No item 3.6.1, abaixo, essa peculiaridade será examinada como fator caracterizador dos pactos parassociais.

${ }^{197}$ Sobre a perspectiva da prática norte-americana a respeito de ajustes de compra e venda como válvulas de saída e sua fundamental importância na gênese do relacionamento societário, esclarecedores os ensaios de cf. Elliot M. SURKin, "How do I get out of here? 
Nesse cenário, a função integradora do pacto parassocial patrimonial é evidenciada, na medida em que oferece às partes a possibilidade de regrar, de antemão, aspectos potencialmente danosos à associação e/ou ao negócio comum.

Com efeito, os ajustes relativos à compra e venda de participações societárias apresentam distintivo traço programático, com a determinação dos critérios e parâmetros dentro dos quais futura compra e venda deverá ser realizada entre os sócios e, principalmente, a enunciação de liames entre a ocorrência de eventos próprios àquele relacionamento (ex.: impasse, alteração de determinada circunstância etc.) e a conclusão da compra e venda e/ou exercício de opção de compra ou de venda.

Além disso, a vigência de cláusulas desse gênero desde o início do relacionamento societário permite que se tenha panorama mais concreto tanto das hipóteses em que a saída dos sócios deve ocorrer, como de efeitos que dela decorrem, seja com relação ao patrimônio dos sócios como também para a companhia ${ }^{199}$.

A discussion of exit strategies in closely-held real estate LLCs" in The practical real state lawyer, Maio 2002, disponível em http://files.aliaba.org/thumbs/datastorage/lacidoirep/articles/PREL_ACFA3DB thumb.pdf. Do mesmo autor "When Joint Venturers Can't Agree - The Buy-Sell Revisited" disponível em http://www.acrel.org/Documents/Seminars/a000028.pdf.

198 Cf. Daigre e Sentilles-Dupont, Pactes..., cit., p. 17.

199 Já é possível perceber, aqui, alguns indícios de eventual desvirtuamento da disciplina societária. Seria lícito, por exemplo, que as partes determinassem, contratualmente, todos os múltiplos aspectos envolvidos na dissolução do vínculo societário entre elas, quando a lei vigente sobre o tipo societário em questão não apresenta - e nem pode apresentar tantas minúcias? Em caso positivo, quais os freios que se apresentam para a irrestrita liberdade contratual? Vale aqui determo-nos em um exercício: a lei de sociedades anônimas prevê regras de reembolso de ações pela companhia em casos específicos, com indicação de critério para apuração do valor a ser pago ao acionista. Não se tratando de hipótese de dissolução do vínculo societário autorizadora do reembolso, poderiam as partes superar a limitação legal de hipóteses, fazendo valer entre elas regime diverso, justificando-o com a utilização de acordos de compra e venda de participações? Nesse sentido, cf. Luis Gastão Paes de Barros Leães, Acordo de Acionistas e Opção de Venda ("PUT") in Pareceres, Vol. 2, São Paulo, Singular, 2004, p. 1395. 
Exemplificando: a saída de um sócio que decide fazer valer os acordos de compra e venda celebrados com os demais pode não gerar efeito financeiro direto para a companhia, tendo em vista que será o adquirente - e não ela quem pagará o preço das ações, ao contrário do que ocorre, por exemplo, no recesso ${ }^{200}$.

Todavia, o impacto dessa retirada, para a companhia, pode não ser inócuo se a presença do acionista alienante no quadro societário for vital para o êxito da sociedade, considerando sua posição global de sócio e as prestações acessórias a ele ligadas ${ }^{201}{ }_{2}^{202}$.

Tomando o exemplo acima, é necessário avaliar as regras de compra e venda, e mesmo o seu exercício, sob a ótica de colaboração societária, que justifica e embasa o relacionamento até então existente ${ }^{203}$.

\footnotetext{
200 A propósito, ainda que não raros, acordos parassociais prevendo a obrigação de a companhia adquirir as ações dos acionistas signatários na ocorrência de determinado evento são passíveis de contestação na medida em que a aquisição das próprias ações pela companhia, em benefício do sócio que se retira, pode ferir o interesse social e somente é autorizada em casos específicos constantes do art. 30 da Lei 6.404/76. Criar-se-ia, nesse caso, uma forma de recesso ou de resgate contratual, o que não parece adequado. De fato, se a lei de sociedades anônimas prevê expressamente a hipótese de resgate de ações, seria mais consentâneo estruturar a saída do acionista com base em ações resgatáveis, prevendo no estatuto as condições de resgate. (Cf., considerações já tecidas em MARIANA Conti CRAVEIRO, Alguns aspectos jurídicos..., cit..)

${ }^{201}$ Cf. Stedman e Jones, Shareholders'Agreements, cit., p. 246.

${ }^{202} \mathrm{Na}$ opinião de CARVAlhosA, contudo, "[a]inda que a alteração da titularidade das ações possa influir no poder de controle societário, para a companhia é juridicamente irrelevante tal alteração" (Comentários, cit., p. 565).

${ }^{203}$ Ver-se-á no Capítulo 4 que a situações como a ora descrita é preciso avaliar o exercício do direito do alienante e do adquirente com vistas ao relacionamento societário e a boa-fé que nele deve imperar. COMPARATO esclarece, nessa linha, que acordos de compra e venda e preferência entre sócios não são meras obrigações bilaterais isoladas, mas incluem-se no bojo do contrato plurilateral que é base do relacionamento entre elas, do qual decorre a necessidade de observância da boa-fé e a fidelidade societária ("É que a venda de ações, em tal hipótese, deixa de ser um contrato bilateral isolado, em que cada parte persegue interesses próprios que se contrapõem, mas insere-se no contexto de uma relação plurilateral, na qual a satisfação dos interesses individuais fica subordinada à realização do interesse comum". Restrições à circulação de ações..., cit., p.50)
} 


\subsection{1 - Opções de compra e de venda de ações}

Desdobrando o núcleo básico da previsão de regras sobre o regime da compra e venda entre sócios, tem se consolidado na prática societária a outorga de opções de venda ("put options") e/ou de compra ("call options") relativas à participação societária dos contratantes.

De fato, é difícil encontrar sociedade anônima fechada, atualmente, em que essas modalidades de pactos não existam, sobretudo em se tratando de "joint ventures" ou de sociedades alvo de investimento em capital de risco por parte de fundos de "private equity" ou "venture capital", que são o foco das considerações ora empreendidas. Ou seja, repita-se, passou a ser "típico" nessas formas de associação societária a sua estruturação com base nessas opções ${ }^{204}$.

A outorga de opção de compra ou de venda ("call" e "put options") tem por finalidade conferir à parte beneficiária, respectivamente, o direito de comprar as ações do outorgante ou vender-lhe suas próprias ações, na ocorrência de determinado evento deflagrador, desde logo previsto. Igualmente são previstas opções cruzadas, as "buy or sell clauses" ${ }^{205}$.

A função econômica da pactuação é, também aqui, ligada a necessidade de previsão antecipada de saída do acionista do negócio, pelas mais variadas

\footnotetext{
${ }^{204}$ Nota-se, mais uma vez, o fenômeno da "tipificação social", referido na nota 111.

${ }^{205}$ Para exame acurado sob a perspectiva societária, no direito francês, cf. PAUL LE CANNU, Validation de la clause buy or sell, et durée des pactes d'actionnaires (CA Paris, 3e ch. B, 15 déc. 2006, CMP, STIM et CGTH c/ SNCM et CMN, D. 2007. AJ 162), in RTDCom, janeiro - março, 2007, pp. 169-74. Sobre as opções cruzadas, cf., ainda, AlAin CourET, Cession d'actions. Échange de promesses unilatérales réciproques. Promesse synallagmatique. Vente parfaite. Note: Cession d'acions: réqualification de promesses croisées en vente parfaite, in Bulletin Joly Sociétés, Março, 2006, pp.377-386. Para a questão do preço nessas cláusulas, designadas jocosamente na prática como "omelete, suecas, texanas, sicilianas, americanas, shot gun, roleta russa ou escolha de Salomão", cf. GÉraldine GoffauX-Callebaut, Du contrat..., cit. p. 258-9.
} 
razões, de acordo com peculiaridades ínsitas a cada relacionamento societário ${ }^{206}{ }^{207}$.

Entre os eventos ensejadores do exercício das opções, ressaltam-se as situações de impasse ("deadlock") entre sócios, em que os ajustes têm por objetivo permitir o "way out", com deslinde amigável e supostamente célere para o imbróglio ${ }^{208}$.

Considerando a perspectiva ora adotada, um ponto de reflexão que se deve desde já apontar e tem sido bastante discutido, sobretudo, na doutrina e jurisprudência francesas e italianas ${ }^{209}$, deriva da circunstância de, não raro, as

\begin{abstract}
206 Hermes Marcelo HUCK explica que "[o]s mecanismos de saída da nova sociedade, formulados para um ou outro sócio, são temas desagradáveis no repertório da engenharia de uma joint venture. Discutir o way out quando se inicia um novo empreendimento, estruturado sobre a convicção do sucesso, é a admissão de um possível fracasso, que o empresário não aceita encarar. Entretanto, tais mecanismos estão presentes na grande maioria de novos negócios. Com efeito, é reiterada a outorga de opções - recíprocas ou unilaterais - entre sócios objetivando a saída do negócio comum. Se a associação falhar, se as expectativas não forem alcançadas, qualquer dos sócios - ou um deles - tem o direito de retirar-se da sociedade, cabendo ao outro a obrigação de pagar determinado preço pela participação societária do retirante. É uma fórmula sábia e eficiente para evitar polêmicas de difícil solução, consumidoras de tempo e de recursos e fatais causadoras de desgastes irrecuperáveis aos sócios e, principalmente, à própria sociedade. A alternativa de retirada será eficaz, na medida em que seja praticamente viável e juridicamente válida (Pactos societários leoninos, in RT 760 - Fevereiro/1999, p. 65).
\end{abstract}

207 Anota CARNEIRO DA FRADA, a respeito da função do pacto em prever regra de exclusão ou exoneração do quadro social, que "são raras as sociedades (...) que prevêem ou regulam no seu pacto o direito de exoneração. Porém, nos acordos parassociais, abundam figuras como a call option, o tag along right, etc., os quais, sendo tecnicamente distintos da exoneração, perseguem o mesmo escopo de desinvestimento econômico e delimitação do risco também associado à exoneração" (Acordos parassociais “omnilaterais”... cit., p. 3176 , nota 18).

${ }^{208}$ Outros eventos comuns são, por exemplo, o término do ciclo de investimento em caso de operações de private equity ou o atingimento de determinada etapa em projeto comercial levado a cabo pela sociedade. Como já se destacou em outra oportunidade "[n]o caso específico das operações de private equity, as opções prestam-se a garantir ao fundo a venda de sua participação no momento em que o investimento atinge seu ápice de rentabilidade ou a fornecer-lhe alternativa caso ocorram eventos patológicos que tornem a permanência na sociedade indesejada" (MARIANA CONTI CRAVEIRO, Alguns aspectos jurídicos..., cit..).

209 Como já se destacou no artigo Alguns aspectos jurídicos do desinvestimento nas operações de private equity os pactos leoninos são tratados, entre nós, por dois principais artigos. O mais antigo, da lavra do Prof. LuIs GASTÃo PAES DE BARROS Leães (Pactos Parassociais. Natureza jurídica - Execução específica - Opção de recompra de participação acionária e inexistência de infringência dos arts. 288 do Código Comercial e 1372 do CC por não configurar pacto leonino, in RT 601, 1985, pp. 40-49) e, de outro 
opções de venda acuradamente estruturadas isentarem o acionista do risco do negócio.

Realmente, como defende Huck, a hipotética opção de venda que tenha por evento autorizador estar a sociedade em situação de prejuízo pode fazer com que seu beneficiário não participe das perdas inerentes à qualidade de sócio e, assim, ser tida como pacto leonino.

Ainda neste exemplo, se os pactos parassociais patrimoniais não forem examinados pela ótica de sua função econômica integradora da disciplina global da dinâmica societária existente entre os sócios, um ajuste como o acima comentado não terá sua nocividade prontamente reconhecida. Ao contrário, não é raro encontrar argumentos no sentido de que se lhe deve aplicar apenas a teoria geral dos contratos, visto que não se trata de cláusula aposta no contrato ou estatutos sociais ${ }^{210}$.

lado, o já célebre Pactos Societários Leoninos, de autoria do Prof. Hermes MARCELo HUCK (In RT 760, 1999, pp. 65-73). Na França a discussão é mais intensa e há divisão entre as Câmaras Comercial e Civil da Côrte de Cassação, conforme noticia EMmANUELLE ClaUdel (Clauses léonines extra-statutaires, les vois d'un compromis, in Mélanges Jeantin-Prospectives du droit économique, Paris, Dalloz, 1999, pp. 184-186), Cf. ainda, entre outros: Claude Champaud e Didier DANet. Clause léonine. Pacte d'actionnaires. Promesse de rachat d'actions. Prix minimum. Caractère léonin (non) (Com. 16 nov. 2004, Belkhelfa et autre c/ Rossler). in RTDCom, jan.-mar. 2005, pp. 111-16; FABIEN KENDÉRIAN, La contribution aux pertes sociales, in Revue des Sociétés 4, out.-dez. 2002, pp. 617-51; Gustavo Minervini, Partecipazione a scopo di finanziamento e patto leonino in Contratto e Impresa, 1988, p. 771 e ss.; GABRIEllo PiAZZA, La causa mista creditosocietà in Contratto e Impresa, 1987, pp. 803 e ss. e Patto leonino In: Enciclopedia del diritto, XXXII, Milano, Giuffrè, 1982, pp. 526 e ss.

210 Checar, para esse raciocínio, Luis GASTÃo PAES DE BARros Leães, Pactos Parassociais. Natureza jurídica... cit. pp. 46-4. FÁBIO Konder COMPARATO tece severas críticas a essa posição, visto que a circunstância de o pacto leonino constar de instrumento separado do contrato seria indiferente para a determinação de sua nulidade e poderia, ao contrário, ser indício de aspecto fraudulento da suposta relação societária ( $O$ direito aos lucros nos contratos in Direito Empresarial-Estudos e Pareceres, São Paulo, Saraiva, 1990 p.169), no que é acompanhado por Hermes MARCELo HuCK : "não faria sentido jurídico - ou mesmo lógico - admitir que a simples estipulação de cláusula de exoneração de prejuízos feita em contrato apartado fosse suficiente para retirar da mesma a carga de ilicitude. Fora assim, por um esperto expediente de ordem formal, as partes poderiam evitar a incidência de uma norma de ordem pública que (...) consubstancia o corolário do princípio da comunhão de escopo, essencial em todo e qualquer contrato de sociedade" (Pactos societários..., cit. p. 71). 
Ou seja, muitas vezes se examina o pacto fora da perspectiva do relacionamento societário e da capacidade de burla a princípios ínsitos à própria noção de sociedade, adotando-se critério meramente formal para justificar essa posição ${ }^{211}$, o que não parece admissível.

\subsection{2 - Acordos de venda conjunta}

Outro grupo de cláusulas parassociais de larga utilização, relativas à compra e venda de participações, é o dos chamados acordos de venda conjunta.

Neles, procura-se estabelecer obrigações e direitos de uma parte participar (no "tag along") ou de fazer com que a outra parte participe (no "drag along") da oportunidade de venda do pacote acionário.

Manifesta-se também com esses ajustes a função do pacto parassocial patrimonial na configuração do relacionamento societário entre as partes, visto que permitem que seu interesse econômico em disciplinar a participação na venda de lote de ações seja atendido. Cumpre passar a exemplos para tornar a explanação menos abstrata.

\section{a) Direito de venda conjunta - tag along right}

No ajuste designado como "tag along" ${ }^{12}$, uma parte obriga-se a incluir a participação de outro (ou outros) pactuante(s) na negociação de venda a terceiro de sua própria participação. Há, portanto, o direito de o(s) beneficiário(s) vender(em) sua participação conjuntamente à daquele que

\footnotetext{
${ }^{211}$ Cf. ainda, quanto a pacto leonino contido em ajuste parassocial, MARIO LEITE SANTOS, Contratos Parassociais e Acordos de Voto na Sociedade Anônima, Cosmos, Lisboa, 1996, pp. 74-77 (do qual vale destacar o trecho da p. 76: "O pacto leonino extra-estatutário deve ser considerado nulo, mesmo quando celebrado por apenas parte dos sócios, e tenha por objecto prestações equivalentes e não idênticas às diretamente sancionadas por lei").

212 A expressão em inglês foi mantida em decorrência de seu intenso uso na prática societária brasileira.
} 
assim se obrigou, pelas mesmas condições ou em condições previamente concordadas ${ }^{213}$.

Com origem no direito norte-americano, os ajustes prevendo o direito de saída conjunta têm por escopo proteger os minoritários em caso de venda do controle de uma companhia. Por meio da contratação, os minoritários, têm a oportunidade de participar, nas condições previstas, do prêmio de controle pago pelo terceiro ao controlador. $O$ ajuste é igualmente relevante ao propiciar ao minoritário uma via de saída da sociedade frente à alternância de controle, não permanecendo associado a novo sócio com o qual nem sempre poderá ter boa relação.

Sobretudo nos casos em que a relação societária tem marcado caráter intuitu personae, a integração da disciplina do relacionamento entre sócios com os ajustes de venda conjunta é fundamental ao garantir que o minoritário tenha a chance de aproveitar a oportunidade de venda obtida pelo controlador.

\section{b) obrigação de venda conjunta - drag along right}

Nos pactos que prevêem a obrigação de venda conjunta ("drag along right"), o acionista obriga-se a alienar suas ações juntamente com aquelas de outro, que as pode oferecer a terceiro dentro de um mesmo lote, nas condições que restarem decididas entre o terceiro e o acionista que capitaneia a negociação.

O acionista vinculado ao "drag along" encontra-se, portanto, em situação de sujeição, correspondente ao direito potestativo do credor da obrigação em solicitar a inclusão das ações no pacote negociado se as condições previstas no ajuste tiverem sido cumpridas (e.g: preço mínimo, condições de pagamento).

\footnotetext{
${ }^{213}$ No direito brasileiro há a previsão legal de Tag Along na alienação de controle de companhia aberta, cf. art. 254-A da Lei 6.404/76.
} 
A aceitação de cláusulas potestativas como as que acima referimos está longe de ser pacífica no Brasil. Ao contrário, nossa tradição aponta para a possibilidade de o devedor insurgir-se contra os termos em que o credor da obrigação potestativa quer ver a alienação concluída ${ }^{214}$.

$\mathrm{Na}$ redação da cláusula, assim, convém cuidar de critérios objetivos para o preço que o credor da obrigação estará autorizado a negociar com terceiro, na tentativa de minimizar o risco de que o devedor procure caracterizar arbítrio na determinação do valor de venda entre o terceiroadquirente e o acionista credor da obrigação.

A lógica de elaboração das cláusulas de "drag along" assenta-se, justamente, em fornecer ao credor da obrigação a possibilidade de negociar o pacote acionário com autonomia frente ao proprietário das ações e, de outro lado, que o adquirente possa ingressar na sociedade sem dever relacionar-se com minoritário que, a seu ver, não seria essencial ao negócio. Como se verá no Capítulo 4, contudo, cláusulas dessa natureza não podem representar expropriação das ações do acionista devedor.

Importante apontar que na cláusula de "tag along”, antes comentada, o problema não se verifica por ser a venda conjunta um direito do acionista vinculado. Se as condições de venda pactuadas com terceiro não forem interessantes, ele poderá sempre renunciar ao seu direito de venda conjunta, sem a conclusão da alienação de suas ações.

Como essa alternativa não é a ideal, tendo em vista todas as motivações que levam o acionista a estipular o direito de "tag along", também neste caso é importante que a cláusula de “tag along” preveja dados objetivos e mínimos

\footnotetext{
${ }^{214} \mathrm{Na}$ vigência do Código Civil de 1916, o art. 1.125 previa expressamente ser nulo o "contracto de compra e venda, quando se deixa ao arbítrio exclusivo de uma das partes a taxação do preço". O Código Civil vigente reproduziu a regra no art. 489. Permitiu, entretanto, que o preço seja fixado por terceiro designado pelas partes (art. 485) ou mesmo seja determinado pela cotação em bolsa em determinado dia e lugar (art. 486). Por fim, o art. 487 prevê a hipótese em que a determinação do preço pelas partes seja realizada com base em índices determinados ou determináveis.
} 
de determinação do preço, de forma que o acionista beneficiado não se veja forçado a renunciar a seu direito por não concordar com o valor de venda combinado com o terceiro.

Considerando as possíveis dificuldades na execução específica das obrigações contratadas (tanto no caso de "tag along" como "drag along"), verifica-se, na prática, a inclusão de penalidades bastante severas para desincentivar o descumprimento da obrigação ou mesmo a sua conjugação com opções de compra ou de venda. O objetivo, então, seria garantir ao acionista beneficiário diversas ferramentas para, afinal, obter o resultado desejado ${ }^{215}$.

Na configuração de relacionamentos societários sempre mais complexos e sofisticados, é inegável a relevância de pactos como os acima comentados, incluídos e integrados ao regime vigente entre as partes por meio da contratação parassocial. Nesse sentido, eles se incluem no estado de sócio dos pactuantes, gerando expectativas legítimas quando à possibilidade de saída do relacionamento nos termos pactuados.

\section{3 - Acordos restritivos da circulação de ações}

Os ajustes fundados sobre a compra e venda de participações são frequentemente formatados considerando, ainda, cláusulas relativas à restrição da circulação de ações ${ }^{216}$.

Como traço comum, essas cláusulas cumprem função econômica ligada à necessidade de preservação do quadro de sócios, em vista de exigências específicas do relacionamento em questão $\mathrm{O}^{217}$.

\footnotetext{
${ }^{215}$ Cabe ressaltar, porém, que as cláusulas de saída conjunta não conferem a possibilidade de adjudicação imediata e automática, ao terceiro, das ações do acionista a elas vinculado, tendo em vista que o direito brasileiro somente admite a transferência compulsória de propriedade em situações muito específicas.

${ }^{216}$ V. MARIAna Conti Craveiro, Aspectos societários... cit. p 129-133 e 143.

217 Eles garantem a "possibilité de surveillance de la composition du capital” (GERALDINE GoffauX-Callebaut, Du contrat ... cit, p. 250). Para as diversas utilizações das cláusulas
} 
Nesse sentido, são previstas (i) as diversas modalidades pelas quais o direito de preferência na aquisição das ações pode ser erigido entre as partes, e a relativa disciplina ${ }^{218}$; (ii) cláusulas regulando a necessidade de aprovação dos sócios para o ingresso de terceiro na sociedade (cláusulas "di gradimento" ou "d'agrement") e, ainda (iii) cláusulas prevendo a permanência do acionista na sociedade por período mínimo de tempo (as "lock in" ou "lock up clauses").

As cláusulas de restrição da circulação das ações têm por objeto permitir, também, a eficácia de acordos de voto ${ }^{219}$.

Além disso, considerando uma vez mais o caráter intuitus personae de que tipicamente se revestem as sociedades em que esses pactos são

de restrição de circulação no contexto de sociedades fechadas que receberam investimento de "venture capital" e/ou que dão corpo a uma relação de joint venture e sua motivação do ponto de vista da lógica comercial que embasa ambas as situações, cf. STEDMAN E JONES, Shareholders'Agreements, cit., capítulos 3 e 4. Dentre as principais causas de utilização de referidas cláusulas podemos apontar, com base nesses autores: (i) necessidade de comprometimento das partes com o negócio; (ii) atuação específica e intensa de uma das partes (ou de cada uma delas) como condição indispensável do sucesso do negócio; (iii) presença de "collateral agreements" entre as partes, ou seja, previsão de obrigações acessórias como licenciamento de direitos de propriedade intelectual, fornecimento de matéria prima e/ou serviços, utilização de ativos pela companhia, entre outros (idem, p. 245-246). Cf., ainda, Maria Is Abel De Almeida Alvarenga, Finalidades do direito de preferência para a aquisição de ações in AAVV, Temas de Direito Societário e Empresarial Contemporâneos. Liber Amicorum Prof. Dr. Erasmo Valladão Azevedo e Novaes França, Malheiros, São Paulo, 2011, pp. 472-491. Por fim, TrajAno DE MiRANDA VALVERDE acrescenta que "[é] fora de dúvida que as restrições à circulação das ações concorrem para as afastar do mercado, impedindo-se, assim, o ingresso na sociedade de pessoas que podem ter interêsse na sua ruína, ou não oferecem as garantias morais ou pecuniárias necessárias, aferidas segundo o critério dos atuais acionistas" e mais adiante, que a medida "visa, muitas vezes, garantir a estabilidade da administração da companhia. É um meio indireto de impedir que a sociedade, de um momento para outro, caia nas mãos de concorrentes, ou de pessoas que não se preocupam senão com o lucro imediato" (Sociedade por ações, cit, Vol. 1, p. 211).

218 Sobre cláusulas de preferência, cf., Cf. José Alexandre TAVAres Guerreiro, Interpretação de Preferências na Lei de Sociedades Anônimas in A AVV, Temas de Direito Societário e Empresarial Contemporâneos. Liber Amicorum Prof. Dr. Erasmo Valladão Azevedo e Novaes França, Malheiros, São Paulo, 2011, pp. 389. Michel Dagot, Le pacte de préférence, Paris, Litec, 1988, Antoine Gaudemet, La portée des pactes de préférence

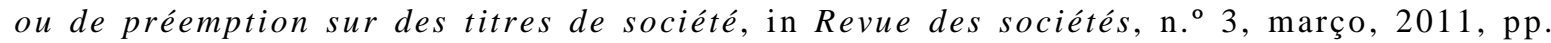
$139-148$.

219 Ou seja, de nada adiantaria vincular o voto se o acionista permanecesse livre para alienar suas ações. 
celebrados, eles têm por mira garantir a permanência daquele acionista cujas características o fazem crucial para o negócio e, ainda, evitar o ingresso de acionistas não desejados (e.g. concorrentes ${ }^{220}$.

\section{a) cláusulas de preferência}

As formas mais comuns de disciplina do direito de preferência na aquisição de participação societária, no Brasil, são os chamados "first refusal rights" (direito de primeira recusa), ainda que, na prática, haja ainda os "first offer rights" (direito de primeira oferta). A preferência pode, ainda, ser contratada em benefício de todos os sócios, indistintamente, ou apenas de alguns.

Tratando-se de cláusulas de first offer, o acionista a ela vinculado, que pretende alienar suas ações, deve oferecê-las, em primeira mão, aos demais acionistas signatários do pacto, para que façam uma primeira oferta para o lote de ações oferecido. Não se concluindo o negócio pelo valor ofertado, o acionista que deseja vender suas ações estará livre para oferecê-las a terceiros, desde que o faça por preço e condições melhores que aquelas oferecidas pelos titulares do direito de preferência. Ou seja, os acionistas titulares do direito têm a possibilidade de assinalar qual será o valor mínimo de venda das ações ${ }^{221}$.

Tratando-se de cláusulas de first refusal o procedimento é diverso. O acionista que deseja alienar sua participação, tendo ou não recebido oferta de terceiro, informa aos titulares da preferência sobre seu intento, indicando o preço desejado pelas ações, bem como as demais condições do negócio.

\footnotetext{
220 No direito italiano, BUtTaRo explica que "essendo nel nostro ordinamento la circolabilità delle azioni elevata a principio di ordine pubblico (...), le clausole statutarie possono prevedere solo delle limitazioni al trasferimento inter vivos delle azioni, e non anche contenere un divieto assoluto di alienazione, divieto che costituisce invece di regola l'oggetto dei sindacati di blocco, ed in quanto solo in tal modo si garantisce la compattezza del gruppo" (Sindacati azionari, cit., pp. 427).

${ }^{221}$ Cf. Davide Proverbio, I patti parasociali, Milano, Ipsoa, 2004, p. 47.
} 
Caso haja oferta de terceiro, é comum que existam previsões obrigando o sócio a comunicar seus dados aos demais, concomitantemente à oferta. Inexistindo oferta de terceiros, é igualmente usual que se preveja a necessidade de o acionista primeiramente ofertar suas ações a terceiros e, estipulado o preço e as demais condições da venda, repassá-los aos acionistas para que, querendo, façam-se substituir ao terceiro no negócio.

Aponta-se como vantagem da modalidade de first refusal o fato de permitir aos acionistas beneficiários do pacto tanto a prioridade na aquisição das ações, como também a possibilidade de bloquear o ingresso de terceiro indesejado; ao passo que na hipótese de first offer, uma vez recusado o negócio pelos acionistas, o terceiro está livre para vender, em princípio, a qualquer terceiro, respeitadas as condições negociais da oferta originária ${ }^{222}$.

\section{b) Cláusula de consentimento}

Bastante frequente são também as cláusulas que condicionam a circulação de ações à aprovação prévia dos acionistas ou mesmo de órgãos de administração da sociedade. No direito italiano, são designadas, assim, "clausole di gradimento" (art. 2355 do Codigo Civil) e, na França, "clause d'agrement" ou "de placet" (art. 228-23 Code de Commerce).

Verifica-se, também com relação a essas cláusulas, a preocupação dos signatários do pacto em manter controle sobre o quadro societário, com a oportunidade de avaliar se o eventual novo ingressante ostenta características que se harmonizam com as dos demais, em prol do negócio comum. São manifestações da intensidade do caráter pessoal da associação daquele grupo de acionistas, portanto.

Quando comparadas às cláusulas de preferência, as cláusulas de consentimento teriam a função pura de evitar o ingresso de acionista indesejado sem que, para tanto, os demais acionistas devam adquirir as ações.

${ }^{222}$ Cf. Idem, p. 48. 
Todavia, o mais comum é que as cláusulas de consentimento acompanhem as cláusulas de preferência.

Em caso de cláusulas estatutárias de consentimento que sujeitam o ingresso do acionista à aprovação de órgãos da companhia, debate-se na doutrina brasileira sobre a sua compatibilidade com a regra do art. 36, uma vez que seria impossível regular no Estatuto, com a precisão e minúcia requeridas pela lei, as múltiplas razões que levariam a se decidir pela inadequação da transferência ${ }^{223}$.

Também as cláusulas parassociais de consentimento, muito embora não prevejam a necessidade de aprovação de órgão da sociedade, podem ter por efeito, igualmente, o aprisionamento do acionista que o artigo 36 visa evitar, ao condicionar a alienação de ações a decisão de um ou todos os demais sócios. Essa circunstância demonstra a necessidade de sua interpretação em consonância com princípios societários e não apenas sob o aspecto contratual, como se verá no Capítulo $4^{224}$.

223 Nesse sentido, FÁbio Konder Comparato opina que a redação do art. 36 da Lei n. 6.404/76 "parece excluir a cláusula de placet, pois a especificidade desta consiste, exatamente, na atribuição de um poder arbitrário de decisão ao órgão administrativo ou à assembléia geral, que, por definição, não pode ser regulado 'minuciosamente' nos estatutos" (Cf. O Poder de Controle na Sociedade Anônima, 4a. Ed., Rio, Forense, $2005, \mathrm{p}$. 184). Contra Modesto Carvalhosa: "[n]a doutrina brasileira, divergem os autores a respeito da possibilidade de se estabelecer essa espécie de restrição. Parece-nos que não há qualquer impedimento à sua adoção" (Comentários..., cit, v. 1 p. 354). O autor refere que também TRAJANO DE MIRANDA VALVERDE seria favorável à adoção da cláusula. É preciso notar, contudo, que VALVERDE pondera - quanto à preocupação expressa por FÁBIO Konder COMPARATO -, que "a recusa da sociedade, por seu órgão competente, de dar o seu concurso ou o seu consentimento à transferência de ações, ainda quando pelos estatutos não necessite de motivação, há de ter sempre um fundamento justo, um motivo grave. O nosso direito não reconhece atos de puro arbitrio, quando em jôgo respeitáveis interesses protegidos pela lei" (Sociedades por ações, Vol. 1, cit., p. 212). Em posição mais recente, CAlixto SAlomão Filho indica, a comentar a obra de FABIo Konder Comparato, que a interpretação do art. 36 e das cláusulas que sob ele são criadas devem orientar-se pela proteção do interesse social, ou seja, "quanto mais as cláusulas de limitação à circulação puderem ser justificadas como instrumento de proteção do interesse próprio da sociedade (e não dos acionistas) mais ampla sua interpretação poderá ser" ( $O$ poder de controle..., cit., p. 184).

224 Interessante caso judicial relativo a cláusula de consentimento e à necessidade de arbitramento de preço é examinado por Claude Champaud e Didier Danet, Associé désirant quitter la société. Estimation de la valeur de ses droits sociaux. Application d'un 


\section{c) Cláusulas de permanência (lock in ou lock up)}

Por meio dos ajustes de "lock in" ou "lock up", busca-se garantir a permanência de sócios e/ou fundadores no negócio, bem como a sua atuação comprometida na sociedade.

Essa preocupação é marcante nos casos de investimento por parte de fundos, que determinam seu ingresso na sociedade pela perspectiva de produção de resultados positivos, diretamente decorrentes da atuação dos sócios "operacionais" 225 .

Igualmente, nas “joint ventures”, as cláusulas de permanência são de extrema relevância pois, no mais das vezes, o envolvimento direto e intenso de cada parte é determinante para o sucesso do empreendimento comum. Assim, havendo intenção de uma delas de retirar-se, a presença da limitação de alienação das ações abre espaço para, negocialmente, encontrar-se solução menos danosa para o negócio ${ }^{226}$.

Além das cláusulas de "lock in", os pactos parassociais geralmente prevêm, ainda, ajustes de prestação de serviço pelos quais se requer sua atuação exclusiva e em dedicação exclusiva para a companhia ${ }^{227}$.

convention particulère de rachat. Condition de validité. Détermination expertale de l'article 1843-4 du code civil. Absence d'obligation de préemption à défault de présentation d'un cessionnaire à la société (Paris, 1re ch. A, 30 oct. 2007, Sanchez Ruiz c/ Sté Arts sans Frontières et Sté $M C W$ ), in RTDCom, janeiro - março. 2008, pp. 127-28. Cf. também as considerações de Géraldine GoffauX-CAllebaut, Du Contrat... cit, p. 258.

225 "Essentially, the investor is investing in the skills of the management team rather than in the company. He will be concerned therefore to ensure that the founders remain committed to the company" (STEDMAN E JONES, Shareholders'Agreements, cit., p. 193).

226 "Restrictions on transfer may be of paramount importance in circumstances where the involvement of each joint venturer is indispensable. Where there is the case, the success of the joint venture could be seriously impaired if a party were allowed to transfer its shares and cease to participate in the equity of the joint venture. Of course, locking-in a reluctant party will not always be beneficial, but it should at least prevent one party walking away without finding a solution which is acceptable to both parties" (idem, p. 246)

${ }^{227}$ Nesses casos são previstos, ainda, seguros sobre os profissionais-chave, para os casos de morte ou invalidez (idem, p. 194). 
Com relação ao foco da presente análise, é preciso avaliar que os variados ajustes de restrição de circulação de ações demonstram-se mais que meras obrigações de fazer ou não fazer de um sócio a outro. Ao contrário, essa disciplina - escolhida e aceita pelos signatários - passa a compor seu estado de sócio, gerando legítimas expectativas sobre a manutenção do quadro societário e/ou sobre efeitos derivantes da saída dos sócios sobre seu relacionamento, considerados os diversos papéis desempenhados.

\section{4 - Pactos ligados a outros direitos patrimoniais dos sócios}

Cumprindo a função de integrar a disciplina aplicável aos sócios (e formar, assim o "estado de sócio" antes referido), os acordos parassociais com teor patrimonial não se restringem às pactuações alicerçadas na compra e venda de ações.

Ao contrário, a crescente complexidade e sofisticação dos relacionamentos societários faz com que múltiplos aspectos patrimoniais sejam igualmente tratados em sede parassocial, tendo presente a necessidade de regulação global do fenômeno associativo.

São verificados muito frequentemente na prática societária, destarte, acordos de não concorrência e não restabelecimento, bem como ajustes relativos a prestações acessórias do mais variado tipo, a cargo dos sócios.

Por sua relevância para a configuração da relação societária existente entre as partes, também esses pactos devem, necessariamente, ser compreendidos em função do relacionamento a que se prestam e não de maneira isolada. 


\subsection{1 - Acordos de não concorrência}

A não concorrência entre sócios pode ser apontada como decorrência natural da lealdade que entre eles deve imperar. A realidade, contudo, não é tão evidente ${ }^{228}$.

Diante das diversas circunstâncias que informam a contratação de sociedade, é possível que, em determinados casos, os sócios decidam se associar em um projeto comum justamente por serem concorrentes.

Em outros casos, a sociedade é concorrente de um sócio, sem que tal fato seja necessariamente danoso para qualquer um dos dois; em outras situações, ainda, e ao contrário, a eventual concorrência de um dos sócios frente à sociedade ou a outros sócios pode ser letal para o relacionamento idealizado. E é fácil supor, por fim, que a mera participação de um mesmo sócio no capital de sociedades concorrentes pode ou não ser fator de deslealdade ${ }^{229}$.

Em suma: não há regra unívoca para a questão, o que ressalta a relevância da conformação da disciplina societária vigente entre as partes por

\footnotetext{
228 MARIA JeSUS PEÑAS MOYAno, ao tratar das obrigações de não concorrência como prestações acessórias afirma que elas não decorrem automática e irremediavelmente do princípio de boa fé, eis que "el establecimiento de una prohibición de competência en este concepto no solapa la buena fe que, presidiendo toda la contratación mercantil, há de encontrarse tambien presente en las relaciones entre el sócio y la sociedad y los sócios entre si. Son dos questions independientes y no puede entenderse, de modo general, que una conducta del accionista adecuada al principio de la buena fe genere tal dever de respeto hacia la sociedad que incluya la prohibición de competir com ella. Solamente en algún supuesto excepcional muy remoto, puede deducirse esta obligación como una carga pare el accionista atendiendo al particular objeto social, y no habría necesidad, entonces, de establecer prestaciones accesorias com este contenido" (Las prestaciones accesorias en La Sociedad Anónima, Madrid, Aranzadi, 1996, p. 222). Na opinião de KARSTEN SCHIMIDT, quem se obriga à promoção de um escopo comum não deve comprometê-lo. Por consequência, pode restar obrigado a evitar a concorrência em relação à sociedade, mas também, eventualmente, com relação a seus consócios (in verbis "[w]er sich zur Förderung eines gemeisames Zwecks verpflichtet, darf diesen gemeisamen Zweck nicht gefährden. Demgemä $\beta$ kann er verpflichtet sein, sich einem Wettbewerbs im Verhältnis zu der Gesellschaft, aber eventuel auch zu sein Mitgesellschaftern, zu enthalden" (Gesellschaftsrecht, cit, p. 595).

229 Para exemplos de restrição de concorrência, cf. STEDman E JONES, Shareholders'Agreement, cit., p. 259.
} 
meio de contratação parassocial. Para que o tema da concorrência possa ser adequadamente tratado conforme o contexto específico de cada sociedade, as partes valem-se de pactos parassociais para deixar desde logo avençadas as condições em que atividades concorrentes poderão ser exercidas ou não.

Ao fazê-lo, tratam da não concorrência (i) durante o período em que permanecem sócias e (ii) quando uma delas retira-se da sociedade, estabelecendo frequentemente, neste último caso, obrigação de não restabelecimento ${ }^{230}$.

$\mathrm{Na}$ medida em que essas obrigações suprimem das partes que a elas se vinculam a possibilidade de atuar livremente, fica salientado o caráter patrimonial $^{231}$ e não político da avença. Não se perca de vista, contudo, que essa supressão patrimonial a que as partes se submetem é desejada e celebrada em vista do relacionamento societário e sob esse prisma deve ser compreendida ${ }^{232}$.

${ }^{230}$ Cf. caso da Cia da Juta, clássico na literatura jurídica nacional a respeito do tema da não concorrência e proteção da clientela na alienação de estabelecimento comercial. (Apelação Cível 2.183, STF, Revista do Supremo Tribunal Federal, vol. 2, p. 480-483 e vol. 3 p. 187-194) e Eros Roberto Grau e PAUla A. Forgioni, Cláusula de nãoconcorrência ou de não-restabelecimento. Evolução histórica, função econômica e análise jurídica e Interpretação de Cláusula de Não Concorrência estabelecida em Acordo de Acionistas in $O$ Estado, A Empresa e O Contrato, São Paulo, Malheiros, 2005, pp. 273-300 e pp. 301-310, respectivamente.

231 Examinando cláusulas de não-concorrência pelo prisma do direito do trabalho fica caracterizado o caráter patrimonial do ajuste pois as decisões jurisprudenciais indicam, com frequência, que a licitude liga-se (i) à previsão de prazo de restrição compatível com o mercado em questão e (ii) ao pagamento de contrapartida pecuniária à restrição da liberdade do trabalhador em escolher seu empregador. Cf. TRT-SP, RO n. ${ }^{\circ} 0248400-$ 71.2010.5.02.0053, $17^{\mathrm{a}}$ Turma do E. Tribunal Regional do Trabalho da $2^{\mathrm{a}}$ Região, Rel. Susete Mendes Barbosa de Azevedo; RO, n. ${ }^{\circ}$ 01374007720105020017, $10^{\text {a }}$ Turma do E. Tribunal Regional do Trabalho da $2^{a}$ Região, rel. Des. Cândida Alves Leão; RO N. ${ }^{\circ}$ 0143300-52.2010.5.02.0078, $16^{\mathrm{a}}$ Turma do E. Tribunal Regional do Trabalho da $2^{\mathrm{a}}$ Região, REL. Des. Sandra Curi de Almeida; RO n. ${ }^{\circ}$ 0015600-92.2010.5.02.0046, $16^{\mathrm{a}}$ Turma do E. Tribunal Regional do Trabalho da $2^{a}$ Região, rel. Des. Ana Maria Moraes Barbosa Macedo; RO n. ${ }^{\circ}$ 01983.2005.019.02.00-8 e TST, AI n. ${ }^{\circ}$ TST-AIRR-864/2000-064-01-40.8, $2^{\mathrm{a}}$ Turma, rel. Josenildo dos Santos Carvalho,j. 16.5.07.

232 Não se pode olvidar, é claro, os efeitos anticoncorrenciais que as cláusulas de não concorrência e/ou exclusividade podem gerar. Nesse sentido, "restrictions are not necessarily a bad thing and some may even be crucial to the success of the joint venture. Generally, if the joint venturers can show that they will at least optmise the benefits (...) 


\subsection{2 - Acordos prevendo outras prestações acessórias dos sócios}

Para a constituição de qualquer sociedade anônima é requisito indispensável que o capital social seja formado mediante a contribuição dos sócios, a qual serve de medida de seus direitos e obrigações e é mesmo ínsita à noção de sociedade ("reunião de esforços e recursos") 233 .

$\mathrm{Na}$ sociedade anônima vige a regra de que a obrigação primordial e típica do acionista é a de integralizar o capital subscrito de modo que, ao fazê-lo, o acionista passe a gozar de responsabilidade limitada ${ }^{234}$.

Todavia, tomando em consideração os diversos interesses que afluem para a formulação de um relacionamento societário, constata-se, em número sempre mais expressivo, casos em que fatores alheios à contribuição formal dos sócios ao capital social assumem relevo preponderante para o empreendimento comum ${ }^{235}{ }_{-}^{236}$.

then the restrictions are more likely to be allowed. However, restrictions should go no further than is necessary for the reasonable protection of the parties; anything beyond this is likely to fall foul of applicable competition law" (STEDMAN E JONES, Shareholders'Agreement, cit., p. 259). Sob o tema, cf. também Calixto Salomão Filho, nota de texto 57 in Fábio Konder Comparato e Calixto Salomão Filho, O Poder de Controle... cit..

233 Lei 6.404/76, Art. $7^{\circ}$ - O capital social poderá ser formado com contribuições em dinheiro ou em qualquer espécie de bens suscetíveis de avaliação em dinheiro.

${ }^{234} \mathrm{Na}$ Alemanha, com relação às contribuições dos sócios, distingue-se as concepções de Beitrag, que seriam todos os deveres a que se obrigam os acionistas para que o objeto social possa ser cumprido e Einlage restrita ao aporte acionista para a formação do capital da sociedade e seu patrimônio, determinante de responsabilidade (KARSTEN SCHMIDT, Gesellschaftrecht, cit., pp. 567-568).

${ }^{235}$ Como explica FÁBio Konder Comparato, em texto clássico, “[e]conomicamente, pode suceder que a prestação principal do acionista não seja a participação no capital e, sim, (...) se comprometa a fornecer à sociedade, em condições altamente favoráveis, a matéria prima indispensável à sua produção industrial, ou uma assistência técnica de grande relevância." (Restrições à circulação... cit., p. 37). Exemplo frequente nas sociedades da área de tecnologia da informação é a baixa contribuição monetária para a formação do capital, por parte do acionista "desenvolvedor" da tecnologia, acompanhada, contudo, de sua obrigação de prestação acessória, assumida em pacto parassocial, pela qual seus préstimos - fundamentais ao escopo da sociedade - devem ser realizados. Cf. LUIZ Fernando Amaral Halembeck, Arranjos societários usuais em negócios de Internet, in Luís EdUARDo SCHOUERI, (org.), Internet: o direito na era virtual, Rio de Janeiro, Forense, 2001,pp. 9-15 
Apresenta-se, então, o tema das prestações (ou obrigações) acessórias ${ }^{237}$, que poderiam ser definidas como obrigações sociais relativas à posição de sócio, de caráter acessório e facultativo, onerosas ou gratuitas, reguladas essencialmente nos estatutos sociais e alheias ao capital social ${ }^{238}$.

Para que sejam consideradas como obrigações sociais, porém, geralmente se refere que seja necessário que elas constem dos estatutos sociais, inclusive como medida de proteção do acionista frente ao que dele se exige. Seguindo essa orientação, caso sejam previstas em contratos a latere, devem ser tratadas como obrigações entre sócio e sociedade, com efeitos meramente obrigacionais para o inadimplemento. O critério para que ensejem ou não efeitos societários parece ser, portanto, formal ${ }^{239}$.

No Brasil o art. 120 da lei $6404 / 76$ prevê a possibilidade de suspensão de direitos do acionista faltoso em caso de não cumprimento de obrigação legal e/ou estatutária, o que pode levar à conclusão de que efeitos societários somente são aplicados ao descumprimento de obrigações societárias previstas nos estatutos sociais.

Comparato, contudo, apresenta posição mais ampla, no sentido de que a suspensão dos direitos do acionista pode ocorrer se o inadimplemento da

\footnotetext{
236 Especialmente com relação às joint ventures, STEDMAN E JONES pontuam ser raro encontrar alguma sociedade "which is not dependent on the joint venturers for some resources in addition to finance". Os autores apontam como típicas contribuições acessórias dos sócios (i) direitos de propriedade intelectual, (iii) o fornecimento de mercadorias e serviços, (iii) a colocação de empregados à disposição da companhia; (iv) a permissão de utilização de propriedades, unidades industriais e maquinário e unidades de pesquisa. (Shareholders'Agreement, cit., pp. 252-225).

237 Cf. MARía Jesús Moyano (Las prestaciones..., cit., pp.113-140) para completa descrição das principais obras e da evolução do tema do ponto de vista legal e doutrinário, inclusive sob a perspectiva de direito comparado.

${ }^{238}$ É sempre MARía JeSÚs MOYANO quem assim as conceitua (Idem, cit., p. 68).

${ }^{239}$ Cf. MARIA JeSús PEÑAs Moyano “[u]n simples pacto al margen de los estatutos nunca podría dar lugar a prestaciones de este tipo; simplesmente estaríamos ante relaciones jurídicas independientes entre la sociedad y los socios como terceros, sometidas al derecho común. (...). Es necesario que se ofrezca un cuadro claro y preciso de cuáles son, o cuáles pueden ser, las obligaciones de los socios frente a la sociedad a través de fórmulas jurídicas adecuadas” (Las prestaciones..., cit., p. 67).
} 
obrigação acessória puder ser configurado como falta no dever de colaboração do acionista. Ou seja, mesmo que a prestação acessória conste de pacto parassocial, seu inadimplemento poderia, nesse caso, gerar efeitos societários $^{240}$.

A previsão das prestações acessórias em pactos parassociais é freqüente e o fato de que suas disposições integram o estado de sócio dos celebrantes exige interpretação adequada.

Em muitos dos casos, trata-se de obrigações assumidas apenas por um grupo de acionistas ou mesmo por uma única parte do contrato parassocial. Em outros, a previsão fora dos estatutos diz justamente com a necessária confidencialidade dos termos avençados, não sendo favorável a publicidade que é ínsita aos estatutos.

Com acerto, Oppo, já nos anos 40, identificou essa modalidade de ajustes entre sócios, salientando a peculiaridade de eles serem contratados entre sócios com vistas a gerar vantagem à sociedade ${ }^{241}$.

Nesse particular, muito embora não sejam previstos nos estatutos sociais (e, portanto, em tese, "externos" à sociedade) sustenta-se nesta tese, na linha de Comparato, que os ajustes que estipulam obrigação acessória aos sócios devem ser vistos sob a perspectiva de que também eles integram a formulação desejada pelas partes para aquele relacionamento societário ${ }^{242}$.

\footnotetext{
${ }^{240}$ Restrições... cit., pp. 41-42. V. também o texto de MARIO ENGLER Pinto JR., Exclusão de Acionista in RDM 54, pp. 83-89, em que defende a possibilidade de exclusão do acionista que falta ao dever de colaboração ao inadimplir obrigação de prestação acessória (p. 86-87). Essa reflexão será retomada no Capítulo 4.

${ }^{241}$ In verbis, “(p)ossono essere diretti a procurare alla società vantaggi particolari a carico dei soci e che non vengono previsti nel contratto sociale per evitare la pubblicitá propria di questo, per escludere pretese dirette di terzi, per mantenere alle convenzioni relative una piú facile modificabilitá" (Contratti..., cit. p. 9).

${ }^{242}$ Algumas obrigações acessórias são previstas em benefício ou vantagem para a sociedade e, com relação a elas, é menos árduo sustentar que devam ser objeto de tutela societária. Todavia, é comum que pactos parassociais prevejam prestações acessórias sem reflexo imediato para a sociedade (ex.: permissão de acesso de um sócio ao banco de dados de outro). Também neste caso, ainda que não haja impacto direto para a companhia (entendida
} 
De fato, a ausência de efeitos societários do eventual inadimplemento não afasta a relevância do que foi contratado como conjunto de regras a que se submeteu o sócio em vista daquele negócio, daquele empreendimento comum que as partes tencionavam desenvolver valendo-se, também, das prestações acessórias pactuadas.

É curial que se depare com o argumento de que cabe ao direito societário regular apenas a constituição e o funcionamento da sociedade e que, portanto, matérias não diretamente ligadas a esses aspectos não seriam alvo desse ramo do direito. Como será reiterado no decorrer da explanação, essa posição parece não condizente com a ideia de direito societário tomada sob a ótica da lógica que leva as partes a se associar.

Ao direito societário cabe igualmente tutelar, repise-se, o relacionamento existente entre os acionistas e, nesse sentido, as prestações a que se obrigam no bojo desse relacionamento tornam-se também seu alvo ${ }^{243}$.

Assentada a posição sobre o tema, cumpre passar ao exame de algumas obrigações acessórias habitualmente previstas em pactos parassociais.

a) financiamento, capitalização e distribuição de resultados da sociedade

Não obstante vigorar a regra da responsabilidade limitada dos acionistas ao capital efetivamente subscrito, pactos parassociais prevendo regras para futura capitalização da companhia e/ou seu financiamento por parte de todos ou alguns dos sócios são muito comuns, inclusive para que eles mitiguem,

\footnotetext{
como ente diverso e, em tese, terceiro à pactuação), ele acaba por se fazer sentir sobre $o$ relacionamento entre aqueles acionistas o que, não é difícil supor, tem o condão de alterar a dinâmica entre eles e, reflexamente, afetar a sociedade.

${ }^{243}$ No Capítulo 4, será explorado com mais vagar o tema do dever de colaboração entre sócios e da proteção das legítimas expectativas.
} 
voluntariamente, o benefício da responsabilidade limitada em vista daquele projeto comum que convencionam levar a termo ${ }^{244}$.

Nesse grupo de cláusulas também se encontram regras voltadas à proteção do minoritário contra a diluição de sua participação, tendo em vista os planos de aumento do capital social e a necessidade de futuros aportes ${ }^{245}$. Com essa medida procura-se estabelecer contratualmente proteção mais concreta e efetiva em face das disposições legais antidiluição ${ }^{246}$, determinando, por exemplo, quais casos são autorizadores de aumento de capital e quais, ao contrário, deverão ser resolvidos por meio de endividamento, não se descurando do respeito ao interesse social $^{247}{ }_{2} 248$.

De outro lado e em que pesem as disposições legais e estatutárias atinentes, contrata-se também as condições em que os lucros da companhia

\footnotetext{
244 Prevendo-se, por exemplo, o oferecimento de garantias pessoais do sócio ou a sua obrigação de investir na sociedade mais do que o exigido pela mera integralização do capital subscrito, obrigando-se a participar de aumentos de capital futuro, a reinvestir lucros, entre outras hipóteses. Cf. STEDMAn E Jones, Shareholders'Agreements, cit., p. 248 e 257. O assunto será ainda comentado no item $4.5 .5, \mathrm{c})$.

245 A mesma linha de raciocínio se aplica aos casos de diluição de participação em virtude de operações de reorganização societária. Igualmente, ajustes antitake over são sempre mais comuns.

${ }^{246}$ Como será tratado no item 4.5 .5 , c), a garantia do acionista a não diluição, no Brasil, está expressamente prevista nos art. 109 e $170, \S 1^{\circ}$ da Lei 6.404/76. Art. 170. Depois de realizados $3 / 4$ (três quartos), no mínimo, do capital social, a companhia pode aumentá-lo mediante subscrição pública ou particular de ações. § $1^{\circ}$ O preço de emissão deverá ser fixado, sem diluição injustificada da participação dos antigos acionistas, ainda que tenham direito de preferência para subscrevê-las, tendo em vista, alternativa ou conjuntamente: (Redação dada pela Lei n 9.457, de 1997).

247 A respeito de cláusulas anti diluição ("anti-dilution" ou "pari passu”) cf. DAIGRE e Sentilles-Dupont, Pactes d'Actionnaires, cit. p. 22.

248 Interessante, nesse particular, examinar as controvérsias que deram origem ao caso PETROPLASTIC, relacionadas a ajustes parassociais prevendo regras sobre a participação dos pactuantes nos futuros aumentos de capital e cessão antecipada de ações deles derivantes Confira-se o parecer de Philomeno José Da Costa (RF, 298, pp. 140-151) no caso, em resposta a quesitos formulados sobre a possibilidade de convenção de acionistas alterar a efetivação de direitos consagrados ao acionista, como o de direito de preferência nas emissões de ações. Verifique-se, ademais, o Acórdão da decisão proferida pela $4^{\mathrm{a}}$ Câmara Civil do TJRS em 27.5 .87 e respectivo comentário, pelo mesmo autor (RDM 70, pp.83-93) bem como as considerações de GALENO LACERDA enfatizando a complexidade do caso (Sociedade anônima. Realização paulatina do capital. Acordo de Acionistas in RT 704, pp. 21-35).
} 
deverão ser reinvestidos ou distribuídos, com base nos planos de negócio decididos pelas partes ${ }^{249}{ }_{-}^{250}$, ou ainda formas diferentes de distribuição de lucros entre os acionistas.

Acordos prevendo a distribuição de lucros de forma desproporcional à participação social ou, de qualquer maneira, em benefício de um ou outro sócio são tradicionalmente apontados como uma das ocorrências mais comuns de pactos parassociais ${ }^{251}$. Sua real utilização, contudo, esbarra no necessário respeito ao princípio de vedação de pacto leonino - adiante comentado - e, também, nas diversas implicações fiscais decorrentes da atribuição de lucros de um acionista a outro.

No Brasil, ajustes dessa natureza são mais comuns em sociedades limitadas, com relação às quais encontram amparo legal (art. 1.007, Código Civil Brasileiro), ainda que haja quem os interprete, para efeitos fiscais, como doação. Já nas sociedades anônimas, sua utilização é controversa em virtude de o art. 109 exigir tratamento igual aos acionistas dentro da mesma classe e a transferência de recursos de um acionista a outro, em vista do acordo, ser tributada.

Não se pode deixar de considerar, no contexto atual, que sejam previstos em detalhe, nos pactos parassociais, inúmeros aspectos reunidos nos chamados planos de negócio ("business plans"), tais como o volume de investimentos e prazos de sua realização, com previsão de aumentos de capital, financiamento externo e/ou critérios a serem informados ao Conselho de Administração para chamada de capital autorizado; etapas de consolidação do empreendimento comum e condições de sua verificação e implantação;

\footnotetext{
${ }^{249}$ Naturalmente, essas previsões são acompanhadas de acordos de voto.

${ }^{250}$ Ciente dessa prática, o legislador de 2001 previu, expressamente, no $\S 5^{\circ}$ do art. 118 que os órgãos de administração da companhia aberta deverão fazer constar de seus relatórios anuais as disposições sobre política de reinvestimento de lucros e distribuição de dividendos, constantes de acordos de acionistas arquivados na companhia

${ }^{251}$ Cf. Oppo, Contratti parasociali, cit, p. 7.
} 
eventual abertura de capital ou admissão de acionista investidor, emissão de debêntures, entre outros.

Na linha do que se sustenta nesta tese, a interpretação desses ajustes deve levar em conta a intenção das partes em formatar seu relacionamento com base em todos esses aspectos, não sendo por isso totalmente correto afirmar-se que devam ser considerados como obrigações sujeitas exclusivamente ao direito comum, sem quaisquer conseqüências societárias.

Cabe, então, tecer algumas considerações: o sócio não é obrigado, pela lei, a continuamente aportar novos recursos na sociedade. Mas se ele contratou com os demais que assim faria, é isso o que deve fazer, em benefício da sociedade e em atendimento à legítima expectativa dos demais contratantes pois em muitos casos seu inadimplemento impacta algo que baseou a decisão dos demais signatários em se tornarem sócios.

Se esse ajuste é interpretado apenas com vistas ao direito das obrigações, ter-se-á a execução por perdas e danos e é necessário considerar que a prestação inadimplida pode gerar um grave problema na sociedade e minar em definitivo o relacionamento societário entre as partes.

Ainda mais grave: tomando-se uma interpretação superficial da função dos pactos parassociais patrimoniais, é bastante provável que o devedor da obrigação tente dele se desvencilhar, argumentando que o direito societário não o obriga a financiar a sociedade para além de sua contribuição ao capital social.

Todavia, o contrato por ele firmado em função desse relacionamento societário, sim. Nesse exemplo, o acionista não estaria sendo, também, desleal com os demais sócios ao frustrar o cumprimento do acordo? Sua conduta é conforme os princípios basilares do direito societário, fundados na boa-fé e na lealdade entre sócios e entre sócios e sociedade? Considerações dessa ordem serão retomadas no Capítulo 4. 
b) transferência de tecnologia e cessão em uso de direitos de propriedade intelectual elou ativos.

Para o bom êxito do negócio comum, é normal que as partes avaliem, no patrimônio de cada uma, aquilo que podem trazer ao uso da sociedade ${ }^{252}$.

Assim, é comum convencionar-se que uma ou todas as partes deverão licenciar o uso de direitos de propriedade intelectual, fornecer a tecnologia necessária ao novo empreendimento ou, ainda, franquear o uso de ativos de sua propriedade (como imóveis e maquinários, por exemplo), determinando ainda as condições de remuneração e de prestação ${ }^{253}$.

Não raro, essas obrigações formam o núcleo em torno do qual todo o restante do relacionamento societário deve ser erigido e a sociedade poderá desempenhar seu objeto social.

Por consequência, qualquer turbação que essas obrigações possam apresentar pode comprometer sensivelmente a atividade social, e, portanto, a conduta do acionista responsável por sua execução deve ser aferida não apenas com base nos aspectos obrigacionais, mas, vale repetir, também com vistas ao impacto gerado naquele substrato contratado com os demais acionistas.

\section{c) fornecimento}

Seguindo o mesmo raciocínio, as obrigações de fornecimento de matéria prima e/ou insumos para a sociedade constituem o exemplo clássico de obrigações acessórias ${ }^{254}$.

\footnotetext{
${ }^{252}$ FABio Konder Comparato, Restrições à circulação... cit., p. 33.

253 É comum também que uma das partes, detentora de licença ou de autorização governamental para determinada atuação tenha este como seu grande trunfo na associação (ex: sociedade $\mathrm{X}$ tem licença da ANVISA para vender produtos, enquanto sua sócia $\mathrm{Y}$ tem mais tecnologia para produzi-los).

${ }^{254}$ Moyano explica que elas surgiram da necessidade de se obrigar o sócio a realizar fornecimento em benefício da sociedade, no caso de companhias que extraíam açúcar da beterraba na Alemanha do século XIX (Las prestaciones... cit., p. 37).
} 
A admissão de determinado acionista em sociedade pode estar intimamente ligada à sua capacidade de com ela manter relação de fornecimento de insumos essenciais à sua atividade e/ou em condições mais favoráveis ${ }^{255}{ }^{256}$, ainda que essa obrigação seja assumida apenas em sede parassocial.

Constata-se, aqui, a importante função que os pactos parassociais assumem na modelagem do relacionamento societário. Não sendo o fornecedor um mero credor e sim um credor-acionista, o exame de sua conduta deverá pautar-se também pelos princípios societários, como será evidenciado no Capítulo $4{ }^{257}$.

\section{5 - Conclusão}

A função econômica dos diversos acordos parassociais patrimoniais pode ser apontada como a de formatar, de maneira personalizada, aspectos fundamentais ao relacionamento societário, impactados pelo exercício de direitos patrimoniais dos sócios, de modo que ele se desenvolva nos quadrantes desejados pelas partes, integrando a disciplina dada pela lei e pelos estatutos sociais.

\footnotetext{
255 No direito tributário internacional, o fornecimento de bens e serviços entre sociedades coligadas sujeita-se a regras sobre preço de transferência. Cf. LuIZ EdUARDo SCHOUERI, Preços de Tranferência no Direito Tributário Brasileiro, $2^{a}$ ed., São Paulo, Dialética, 2006, pp. 44 e ss.

256 Uma consequência danosa para o negócio comum em caso de saída do acionista vinculado à obrigação acessória pode ser apontada no fato de que aqueles bens ou serviços até então por ele fornecido em caráter benéfico para a companhia passarem a obedecer os padrões de mercado, ou seja, "at arm's length terms", aumentando o custo experimentado pela companhia (cf. STEDMAN E Jones, Shareholders'Agreements, cit., p. 256).

${ }^{257}$ Deixe-se vincada a lição de Comparato, no sentido de que "a confiança é também um dever do sócio para com os demais, dever de tratá-los não como contrapartes, num contrato bilateral em que cada qual persegue interesses individuais, mas como colaboradores na realização de um interesse comum” (Restrições à circulação... cit., p.40).
} 


\section{3 - DISCIPLINA JURÍDICA DOS PACTOS PARASSOCIAIS PATRIMONIAIS NO DIREITO BRASILEIRO}

\section{1 - Disciplina legal: introdução}

Retomando o que se afirmou no Capítulo 1, o direito brasileiro conta com disciplina legal específica sobre pactos parassociais em sociedades anônimas, consistente no artigo 118 da lei $6.404 / 76^{258}$ que, com relação a ajustes patrimoniais, volta-se apenas àqueles sobre a compra e venda de ações e preferência para adquiri-las.

Segundo a doutrina, a decorrência dessa opção legislativa é a de que somente com relação aos pactos parassociais relativos às matérias previstas no artigo 118 é que devem ser produzidos os efeitos legais da oponibilidade e da execução específica.

Não significa, em absoluto, que pactos parassociais com conteúdo que extrapole o rol legal sejam atacados em sua licitude ou validade ${ }^{259}$. O elenco de

\footnotetext{
258 Já se referiu que inúmeros são os textos, artigos, livros e teses que tratam dos acordos de acionistas previstos na lei 6.404/76. Poucos, senão raros, entretanto, são os que examinam o fenômeno da contratação parassocial para além do modelo legal apresentado pelo art. 118 e suas características próprias. Ou seja, a rica prática societária relativa aos contratos parassociais não tem recebido da doutrina a atenção que sua importância econômica exige.

259 O mesmo se diga com relação aos pactos parassociais celebrados em outros tipos societários: eles podem ser validamente celebrados, mas não são reconduzidos à noção de acordos de acionistas para os fins reservados exclusivamente a eles pela lei. Cf., a respeito o excelente e completo artigo de ERICK CORVo, Acordos de sócios de sociedades limitadas à luz do CC/2002, in AAVV, Temas de Direito Societário e Empresarial Contemporâneos. Liber Amicorum Prof. Dr. Erasmo Valladão Azevedo e Novaes França, Malheiros, São Paulo, 2011, pp. 84-114, do qual se extrai: "muito de debate e das discussões sobre acordos de sócios girou em torno da confusão entre conceitos distintos, tais como licitude, validade e eficácia dos acordos de sócios" (Idem, p. 85). Para a evolução do tema cf., ainda, José Alexandre TAvares Guerreiro, Evolução e perspectivas das sociedades por quotas de responsabilidade limitada, in AASP, São Paulo, p. 102 e prefácio da obra de Celso BARBi Filho (Acordo de acionistas, cit) e WALdiRio BulgaRelli, Anotações sobre
} 
matérias, com vistas ao plano da validade, é enumerativo e a determinação da invalidade é realizada a posteriori ${ }^{260}$.

Ao contrário, no que diz respeito à produção dos efeitos jurídicos previstos em lei a lista é taxativa: somente com relação àquelas matérias eles podem ser produzidos, o que se justifica pelo fato de que se trata de exceções à regra geral de produção de efeitos dos contratos e, portanto, a regra deve ser interpretada de maneira estrita.

Em que pese essa distinção, depara-se frequentemente com manifestações pouco claras e mesmo atécnicas com relação ao problema ${ }^{261}$.

o acordo de cotistas, in RDM 98, pp. 44-49. Cabe referir, por fim, que a sugestão de CElso BARBi Filho de que "na Reforma da Lei das S/A poder-se-ia fazer menção à admissibilidade de acordos de acionistas em outros tipos societários" não foi atendida (Acordo de Acionistas: Panorama atual do instituto no direito brasileiro e propostas para a reforma de sua disciplina legal, in RDM 121, 2001, p. 38). Mais que permitir acordos de acionistas em outros tipos, defende-se, nesta tese, que o artigo 118 deveria tratar de pactos parassociais como gênero de que os acordos de acionistas, com suas peculiaridades, são espécies.

${ }^{260}$ Vale transcrever a completa citação de COMpARATo: “[e]ntre nós, a Lei no 6.404, de 1976, dissipando antigas e infundadas dúvidas, legitimou expressamente os acordos de acionistas como pactos parassociais, assinando-lhes dois objetos: a regulação do exercício do voto e a compra e venda de ações, ou preferência para adquiri-las. Daí não se deve inferir, porém, que se tenha doravante por proibida a celebração de acordos acionários com outros objetos. Na verdade o princípio da licitude desses pactos parassociais existia desde antes do advento daquele diploma legal, como procurei demostrar alhures (...). A validade de tais negócios era, então, como ainda é hoje, submetida às normas comuns do direito privado, a par das regras gerais do direito societário. A promulgação da nova lei de sociedades por ações não veio, de alguma forma, restringir a possibilidade jurídica de utilização de acordos entre acionistas mas, tão-só, disciplinar os seus efeitos em relação a terceiros, inclusive a própria sociedade, dado o princípio da eficácia relativa dos contratos" (Eficácia dos acordos..., cit., p. 76. Grifou-se). Sobre a necessidade de avaliação da validade a posteriori, aferindo-se o conteúdo de cada contrato, cf. PIER Giusto Jaeger e Francesco Denozza, Appunti di diritto commerciale, I, Impresa e

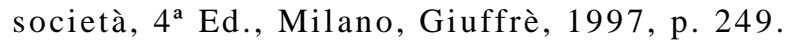

${ }^{261}$ Como exemplo, julga-se questionável a afirmação de CARVALhosa para quem o rol de matérias seria ligado antes à validade que à produção de efeitos legais específicos: "[p]odendo ter por conteúdo a compra e venda e a preferência na aquisição de ações e a vinculação do voto a determinadas diretrizes convencionadas sobre específicos assuntos (acordo de voto e de exercício do poder de controle), a lei não excluiu a eficácia, mas, sim, a validade perante a companhia e terceiros em geral dos acordos de acionistas que versem sobre outras questões, v.g., limitação de responsabilidade pessoal por dívidas da companhia etc." (Comentários..., cit., p. 552. Grifou-se). 
Nesse ponto, como havia sugerido BARBI FILHo, a reforma da Lei das S/A pela Lei n. 10.303/2001 poderia ter alterado a redação original do dispositivo, de modo a aclarar as dúvidas sobre a real finalidade da inclusão de matérias em seu bojo.

Concluindo-se pelo caráter enumerativo da lista de matérias previstas no artigo 118 decorre, como esclarece COMPARATo, que não se pode ligar a locução acordo de acionistas a um único negócio típico, tendo em vista que sob a rubrica é possível criar ajustes com características muito diversas ${ }^{262}$.

Todavia, somente podem ser acordos de acionistas para plena aplicação das regras constantes do artigo 118 da lei de sociedades anônimas os pactos parassociais que tenham por escopo a regulação da compra e venda de ações e relativo direito de preferência, exercício de voto e exercício do poder de controle ${ }^{263}$.

Em que pese essa posição, fundada na necessidade de restrição na aplicação de regra excepcional relativa à oponibilidade, não se encontrou

\footnotetext{
262 Outros, como Albuquerque Barretto, afirmam que se trata de um contrato típico, nominado, pelo fato de a lei ter trazido denominação e características específicas. In verbis: "trazidos para o direito positivo brasileiro pela lei 6.404/76, os acordos de acionistas passam a constituir uma espécie contratual própria, com denominação e características específicas, decorrentes de sua regulamentação" (Acordo..., cit., p. 37). Também Antonio JUNQUEIRA DE AZEVEDo anota que "[n]o direito brasileiro, está previsto na Lei das Sociedades Anônimas (art. 118), sendo, pois, negócio nominado ou típico". (Novos Estudos e Pareceres... cit., p.124).

263 Carlos Augusto Da Silveira Lobo esclarece que "[o]s acordos de acionista são modalidades de 'contrato parasocial', conceito doutrinário criado po Oppo (...) que compreende contratos em que as partes regulam o complementam seus direitos e obrigações como sócios de determinada sociedade e por isso são considerados coligados ao contrato social ou acessório deste. Como exemplo de contratos parassociais, que não se enquadram na definição de acordo de acionistas, cabe citar os chamados 'acordos paralelos', comuns em joint ventures, mediante os quais os acionistas se obrigam a prestações não compreendidas no âmbito do contrato social e do estatuto, mas essenciais ao empreendimento comum a ser realizado através da sociedade empresária" (Acordo de Acionistas ... cit, , p. 441). Mais adiante no mesmo texto reforça que "frequentemente, no mesmo instrumento sob o título "acordo de acionistas" são reunidos outros pactos parassociais que as partes convencionam, mas as disposições especiais do art. 118 somente se aplicam às estipulações compreendidas no conceito legal de acordo de acionistas" (idem, p.445).
} 
justificativa para que o artigo 118 tratasse apenas dessas matérias, ainda que elas sejam (ou tenham sido, na época da elaboração da lei) as mais relevantes.

Uma redação que contemplasse o gênero dos pactos parassociais e não apenas a espécie delineada pela lei (acordo de acionistas) parece mais adequada para o contexto atual, ainda que se fizesse consignar expressamente que alguns efeitos peculiares somente seriam atribuídos a algumas modalidades de pactos parassociais.

Pelo acima exposto, a expressão "acordo de acionistas" será empregada, doravante, para referência aos pactos parassociais expressamente previstos na lei 6.404/76 que são os únicos aos quais a lei conferiu efeitos excepcionais.

Passa-se, assim, à análise dos principais tópicos da disciplina dos acordos de acionistas, identificando, por conseguinte, seus reflexos para os pactos parassociais patrimoniais ${ }^{264}$.

\section{2 - Oponibilidade e acordos de acionistas}

Mencionou-se no Capítulo 1 que a autorização legal e expressa para que o acordo de acionistas produza efeitos não somente entre as partes, mas também frente à companhia e terceiros, constitui a principal peculiaridade da legislação brasileira frente àquelas que se ocuparam da questão.

De fato, a lei com isso denota coligação mais intensa entre o que é contratado entre as partes do acordo e o resultado dessa contratação na vida da companhia, sobretudo na utilização de acordos de voto.

Como bem salienta CAliXto Salomão Filho, essa interação legalmente desejada denota o reconhecimento, no Brasil, de "centros parassocietários de

\footnotetext{
264 Reitera-se que o objetivo desse exame longe está da apresentação detalhada e aprofundada dos múltiplos e complexos aspectos que se pode retirar do tema dos acordos de acionistas e pactos parassociais em geral no direito brasileiro. Assim, o texto que segue procura oferecer panorama dos principais tópicos da matéria para que se reflita sobre seus efeitos para os pactos parassociais patrimoniais.
} 
poder" influindo sobre a vida social, com a determinação de regras claras para o embate entre ambos ${ }^{265}$. Operou-se aqui, como em nenhum outro ordenamento, uma aproximação do regramento obrigacional do acordo de acionistas com o caráter real das disposições relativas à organização e funcionamento da companhia.

Por essa razão, retomando o que antes se dizia sobre a função econômica de ajustes parassociais patrimoniais, tem-se que os acordos erigidos sobre a compra e venda de participações e/ou relativos à preferência em adquiri-las - porque previstos no artigo 118 - devem produzir os efeitos previstos na lei, o que não acontece com outros ajustes parassociais com teor patrimonial.

Com o intuito de avaliar se existe real diferença de regime entre os diversos pactos parassociais patrimoniais conforme estejam ou não previstos no rol legal de matérias, é fundamental, nesse passo, deter-se sobre $o$ significado da oponibilidade e da produção de efeitos diretos e reflexos, pelo contrato parassocial, avaliando sucintamente os termos em que o princípio da relatividade dos efeitos dos contratos foi mitigado com relação aos acordos de acionistas.

\subsection{1- Relatividade de contratos e acordos de acionistas}

Segundo o princípio da relatividade dos efeitos dos contratos, a relação jurídica contratual deve produzir efeitos exclusivamente entre os pactuantes, a menos que a lei determine, expressamente, de forma contrária ${ }^{266}{ }_{-}^{267}$.

\footnotetext{
${ }^{265}$ O novo direito societário, 2a . ed., São Paulo, Malheiros, p. 96.

${ }^{266}$ Veja-se o caso da estipulação em favor de terceiros, exemplo por excelência de negócio jurídico em que se verifica a produção de efeitos jurídicos na esfera de indivíduo que não é parte da contratação, mas apenas por ela, intencionalmente, beneficiado.

267 Ao tratar da origem da relatividade das convenções LuCiAno DE CAMARGo PENTEADO, explica que o seu conceito deriva dos preceitos introduzidos pela revolução francesa e está profundamente arraigado à construção do modelo da "sociedade civil de indivíduos" (em
} 
O princípio refere-se aos efeitos diretos produzidos pelo contrato, ligados à prestação assumida de uma parte a outra e a pretensão de vê-la cumprida, bem como à responsabilidade de cada uma delas para o adimplemento ${ }^{268}$.

Nesse sentido, não é possível que duas partes contratem obrigação vinculante de uma terceira, responsável pelo seu adimplemento, se esta última não teve a oportunidade de manifestar sua vontade ${ }^{269}$.

Para além dos efeitos diretos ligados ao adimplemento das obrigações contratadas, todavia, reconhece-se que o contrato produz efeitos reflexos sobre terceiros. Mais uma vez, cumpre transcrever a síntese de Comparato, a respeito:

"toda relação obrigacional representa um fato da vida jurídica que, como tal, produz efeitos reflexos sobre terceiros. O mecanismo de produção desses efeitos reflexos está ligado ao conhecimento - efetivo ou presumido - da relação obrigacional por quem não é parte" ${ }^{270}$.

Os pactos parassociais, sendo contratos, não escapam a essas ponderações.

oposição à sociedade estamental) (Efeitos Contratuais..., cit., São Paulo, Quartier Latin, 2007, p. 21).

${ }^{268}$ Cf. Comparato, Novos Eficácia dos Acordos de Acionistas, in Novos ensaios... cit. p. 79.

${ }^{269}$ Luciano De CAmargo Penteado ressalta a importância do princípio da relatividade dos efeitos dos contratos e extrai algumas conseqüências genéricas da relação do terceiro com o contrato: "[o terceiro]: (i) não pode ser parte contra sua vontade ou sem nenhum ato próprio que o vincule à declaração negocial, não podendo ser vinculado ao contrato, o que é conseqüência da idéia geral de que a responsabilidade em direito é pelo ato próprio; (ii) não pode se prevalecer de um contrato de que não é parte, para fazer valer um direito ou obter um benefício qualquer de causa contratual. Até mesmo na estipulação em favor de terceiro, por exemplo, entende-se que o beneficiário da estipulação não pode se valer da cláusula compromissória do contrato entre estipulante e promitente a seu favor. Esta conclusão é paralela à anterior; (iii) não pode também considerar-se obrigado compulsoriamente por dívida contratual alheia sem ato próprio contratual ou fonte legal de imputação de responsabilidade. Assim, o terceiro fica estranho ao contrato, podendo-lhe se aplicar o célebre aforisma: res inter alios acta, neque nocet neque prodest, ou ainda o nemo alteri stipulari potest. Apesar deles, tem se entendido que alguma eficácia o contrato apresenta perante aqueles que não são parte" (Efeitos Contratuais... cit. p. 22).

${ }^{270}$ Eficácia dos Acordos de Acionistas, in Novos ensaios... cit. p. 79. 
Em princípio, suas disposições referem-se exclusivamente às partes contratantes mas, por expressa disposição legal, no caso de serem acordos de acionistas, são oponíveis à companhia quando nela arquivados. Imprescindível, nesse ponto, anotar o que se deve entender por oponibilidade. Para tanto, recorre-se a Luciano de CAMARgo Penteado que explica que

"[a] oponibilidade, no sistema civil brasileiro, pode se referir, no campo contratual, a um poder formativo que decorre do contrato, orientado a formar uma relação jurídica, a uma imunidade, também dele decorrente, no sentido de que os efeitos de cada situação jurídica conflitante com o contrato a ele não será oposta. (...) O poder formativo manifesta-se no direito de preferência e na opção de compra, de modo mais saliente. A imunidade manifesta-se na inalegabilidade do desconhecimento do conteúdo do contrato, na mera permanência do vínculo obrigacional, ainda contra a vontade do interessado. (...) Desse modo traduz-se a favor do contrato oponível um prevalecimento no conflito com outras posições jurídicas com ele conflitantes" ${ }^{271}$

De outro lado, também por regra legal específica, acordos de acionistas são oponíveis a terceiros quando os ônus e obrigações forem averbados nos livros sociais. Por fim, pactos parassociais produzem efeitos reflexos a terceiros, como é possível suceder a qualquer contrato, sejam ou não acordos de $\operatorname{acionistas}^{272}$.

A doutrina procurou interpretar o alcance das disposições legais para que o intrincado texto presente no artigo 118 pudesse ser esclarecido se não com relação a todos os pactos parassociais, ao menos com relação aos acordos de acionistas.

\footnotetext{
${ }^{271}$ Efeitos Contratuais perante Terceiros, São Paulo, Quartier Latin, 2007, pp. 174 e 175 grifou-se.

${ }^{272}$ A aceitação de que contratos produzem reflexos a quem deles não é parte é resultado da evolução dogmática do direito civil e das transformações por que passou o direito das obrigações durante o século XX. Nos dias atuais, esforça-se por delinear a posição intermediária entre a rigidez individualista fundada nos dispositivos originais do Code Napoleón, e o estatismo exacerbado da segunda metade do século vinte (cf. LUCIANO DE Camargo Penteado, Efeitos Contratuais... cit., p. 20).
} 
Nesse sentido, afirma-se que a previsão do arquivamento ${ }^{273}$-formalidade necessária para que o acordo de acionistas seja oponível à companhia - ligase à preocupação de os acordos de voto serem conhecidos e respeitados ${ }^{274}$.

Considerando o impacto do voto na vida da companhia - ou seja, a capacidade de gerar efeitos sobre ela - é facilmente percebida a relevância de se dotar acordos de voto de segurança jurídica e eficácia perante a companhia, evitando que sejam turbados. Pela oponibilidade, a companhia não pode alegar desconhecimento dos termos do acordo de voto.

Por outro lado, a previsão de averbação das obrigações e ônus contratados no acordo de acionistas nos livros sociais procura dar publicidade desses ajustes a terceiros de boa-fé, interessados na aquisição de ações gravadas, sobretudo no que diz respeito a disposições relativas à preferência na aquisição de ações ${ }^{275}$, de modo que de antemão conheçam a oponibilidade de que são munidas em favor dos pactuantes.

Os direitos, obrigações e ônus presentes nos acordos passam, pela averbação, a ter sua integração no estado de sócio reconhecida pela companhia ${ }^{276}$, não podendo o terceiro de boa-fé que eventualmente tenha contratado a compra e venda de ações, em desrespeito ao acordo, fazer valer seu direito perante ela e os demais acionistas.

\footnotetext{
${ }^{273}$ Para o entendimento do que se deve considerar arquivamento, para os fins legais, cf. O Resp 23.668-3, de 1993 comentado em Paulo de Lorenzo Messina e Paula A. Forgioni Sociedade por Ações. Jurisprudência. Casos e Comentários, São Paulo, RT, 1999, p. 37 (referido nas páginas 138-139).

${ }^{274}$ Cf. Comparato, Eficácia dos Acordos de Acionistas, in Novos ensaios... cit. p. 81.

275 Luciano de Camargo Penteado pontua, sobre o tema da publicidade, que "[p]ara a oponibilidade é sempre necessário um plus, uma ostensividade formal do conteúdo da relação jurídica" (Efeitos Contratuais... cit., p. 174). No caso das regras de compra e venda e preferência previstas em acordo de acionistas, para sua oponibilidade a terceiros previu o legislador a publicidade por meio da averbação nos livros sociais.

276 Ainda como efeito da averbação, tem-se que o terceiro adquirente de ações sobre as quais foram contratados termos de acordo de acionistas, se concluida cabalmente a alienação das ações gravadas, neles subroga-se. Tratando-se de outras matérias no acordo, as disposições relativas não são transferidas automaticamente com as ações.
} 
Se a aquisição se deu em desobediência ao pactuado, o titular da preferência desrespeitada ostenta, em virtude da oponibilidade prevista em lei, poder formativo relativo àquela compra e venda ${ }^{277}$. Ciente a companhia do acordo (em virtude do arquivamento e averbação), pode - senão deve, em vista de suas funções registrárias ${ }^{278}$ - recusar o registro de transferência de ações que não guarde respeito que foi contratado parassocialmente.

Reitera-se, nesse sentido, que a preocupação se justifica pelo fato de que os acordos de voto perderiam sua utilidade se o acionista que se comprometeu a votar em determinado sentido estivesse livre para alienar suas ações previamente à Assembléia em questão. Por isso, juntamente com o acordo de voto celebra-se acordo que impede a livre transferência de ações por parte do signatário do acordo.

Pois bem, se esse pacto de restrição à venda não fosse oponível a terceiros, facilmente o acionista que desejasse furtar-se da obrigação de voto concordada venderia, de qualquer maneira, suas ações a terceiros de boa-fé. Optou-se, assim, por dotar a companhia de funções registrárias quanto aos acordos de acionistas nela depositados: a companhia não poderá fazer escriturar em seus livros transferência feita em desacordo com o disposto em acordo de acionistas averbado em sua sede.

\footnotetext{
277 Ainda com Luciano de Camargo Penteado, Efeitos Contratuais... cit., pp. 74-75.

${ }^{278} \mathrm{Cf}$. José Alexandre Tavares in Arnoldo Wald (coord.), O direito na década de 80: estudos jurídicos em homenagem a Hely Lopes Meirelles, São Paulo, RT, 1985, pp. 14349. ${ }^{279}$ Referiu-se no Capítulo 1 a preocupação extrema do legislador de 2001 em como que potencializar a oponibilidade dos acordos de voto e de exercício do poder de controle perante a companhia, por meio da inclusão de novos parágrafos no art. 118 da Lei 6.404/76 com o declarado intuito de fazer a companhia, por meio da atuação do presidente da Assembléia, guardiã das disposições contratadas em acordos de acionistas. Além disso, a companhia passou contar com dispositivo expresso que lhe autoriza solicitar informações sobre o teor do acordo de acionistas às partes contratantes. Diante disso não se pode negar, ao menos no sistema da lei societária em vigor, o pleno reconhecimento do acordo de acionistas como foro de estipulações cruciais para a companhia, ou a regra legal não teria qualquer utilidade.
} 
Eis, assim, descrição sucinta do quadro idealizado pelo legislador para os acordos de acionistas e as razões para restringir a oponibilidade a esse grupo de contratos parassociais.

\section{3 - Oponibilidade e pactos parassociais com outros conteúdos patrimoniais}

Em decorrência do texto legal e do acima exposto, o exame das regras de produção de efeitos de contratos parassociais, para a companhia e terceiros, restringe-se a acordos de acionistas, desdobrando-se a análise, como se apontou, com vistas à oponibilidade de acordos de voto ${ }^{279}$ - que escapam à presente tese - e àquela verificada em acordos de compra e venda de ações e preferência para realizá-la.

Contudo, já se afirmou, acordos de compra e venda e de preferência constituem apenas uma parte dos ajustes parassociais com caráter patrimonial de que se pode cogitar na atualidade.

Com relação, portanto, a pactos parassociais de conteúdo patrimonial que extrapolam ajustes fundados na compra e venda, há que se examinar quais as consequências do fato de que não são oponíveis à companhia $e$ a terceiros ${ }^{280}$.

\footnotetext{
${ }^{279}$ Referiu-se no Capítulo 1 a preocupação extrema do legislador de 2001 em como que potencializar a oponibilidade dos acordos de voto e de exercício do poder de controle perante a companhia, por meio da inclusão de novos parágrafos no art. 118 da Lei 6.404/76 com o declarado intuito de fazer a companhia, por meio da atuação do presidente da Assembléia, guardiã das disposições contratadas em acordos de acionistas. Além disso, a companhia passou contar com dispositivo expresso que lhe autoriza solicitar informações sobre o teor do acordo de acionistas às partes contratantes. Diante disso não se pode negar, ao menos no sistema da lei societária em vigor, o pleno reconhecimento do acordo de acionistas como foro de estipulações cruciais para a companhia, ou a regra legal não teria qualquer utilidade.

${ }^{280}$ Nesse sentido, cf. o entendimento de Luciano de Camargo Penteado: "De modo geral, dever-se-ia considerar os atos jurídicos como inoponíveis. Isso seria conseqüência lógica imediata do princípio da relatividade dos efeitos do contrato. Portanto, naturalmente, um contrato é iniponível frente a terceiros, como regra, sendo necesário, caso questionada a relação jurídica dele decorrente, um remédio processual que é a ação declaratória, de modo
} 
A primeira consequência é a de que, não obstante os pactos parassociais patrimoniais possam dizer respeito a aspectos vitais ao funcionamento da companhia (tome-se, por exemplo, o ajuste sobre a transferência de tecnologia ou o direito de uso de marca de titularidade de um acionista) e, sobretudo, forneçam elementos estruturais do relacionamento entre os sócios, a ausência de regra de publicidade e oponibilidade a seu respeito informa que ela, companhia, não estaria de qualquer forma adstrita à sua observância.

As disposições do pacto parassocial diverso do acordo de acionistas, porque não oponíveis à companhia ou a terceiros, não estão imunizadas em caso de conflito com posições jurídicas com elas contrastantes, seja da companhia, seja de terceiros.

Os acionistas contratantes, únicos vinculados ao ajuste, não conseguem, por decorrência e em plena aplicação do princípio da relatividade dos efeitos dos contratos, obter, imediatamente, qualquer efeito societário dessa contratação, como ocorreria se a obrigação fosse estabelecida nos estatutos sociais ${ }^{281}$.

É preciso ponderar, contudo, que a ausência de regra de oponibilidade não seria bastante para afastar plenamente o dever de a companhia respeitar o contratado, sobretudo quando se tem em mente pactos parassociais firmados por todos os acionistas, cuja função econômica, frise-se, é justamente modelar

a impedir a manutenção da questão como controvertida" (Efeitos Contratuais... cit. p. $174)$.

281 Não é demais repisar, aqui, que a ausência de produção de efeitos societários não equivale a dizer que o descumprimento de pactos parassociais patrimoniais não gere efeitos impactantes do relacionamento societário existente entre as partes (volte-se ao exemplo do descumprimento de obrigação de fornecimento ou de não concorrência que pode levar um sócio a decidir por sua retirada da sociedade, exercendo eventual opção de venda existente em seu favor), ou mesmo que a situação não deva ser examinada sob o prisma da lealdade societária. Essas ponderações serão aprofundadas no Capítulo 4. 
o relacionamento societário pretendido pelas partes em vista daquela companhia e daquele empreendimento comum ${ }^{282}$.

Nesses casos, a dissociação entre o interesse das partes contratantes e o interesse da companhia é reconhecidamente difícil de ser realizada, visto que esse último acaba por se caracterizar como o interesse comum dos sócios uti socii ${ }^{283}$.

O respeito ao que foi pactuado de forma parassocial, nessas circunstâncias, diz com a própria configuração da companhia e do modo pelo qual os acionistas signatários do pacto entendem conveniente e oportuno que ela persiga seu objeto social e que eles se relacionem em vista de seu projeto comum. Seria leviano, pois, sustentar que a companhia reste completamente desconectada da pactuação parassocial, pela simples ausência de regra legal que erija a oponibilidade ${ }^{284}$.

De fato, a regra excepcional de oponibilidade de um negócio jurídico frente a outras posições jurídicas é fundada em regime de publicidade, de

\footnotetext{
${ }^{282}$ Importante notar, contudo, que em muitos casos a companhia não pode ser vista como terceiro com relação aos efeitos do contrato parassocial firmado por sócios, por ser titular de interesse manifestamente afetado pela contratação e, como salienta CompARATO: "[o] conceito de parte não está ligado à manifestação de vontade negocial, mas sim ao interesse, que constitui o núcleo do direito subjetivo, como bem demonstrou a clássica análise de Jhering" (Validade e Eficácia de Acordo de Acionistas. Execução específica de suas estipulações... cit., p. 57). Também LUCiAnO DE CAMRGO PENTEAdo, apoiado em Antonio JUNQUEIRA DE AZEVEdo esclarece a possibilidade de o terceiro ao negócio ser parte com relação a seus efeitos (Efeitos Contratuais... cit. pp. 41/43).
}

283 Sobre a peculiaridade dos contratos parassociais firmados por todos os sócios ou acionistas já apontada, tome-se uma vez mais a lição de Comparato, no sentido de que "os acordos em que são partes, praticamente, todos os acionistas de uma companhia são exequíveis contra ela, mesmo quando esta não tenha sido, formalmente, parte na relação jurídica. E isto pela boa razão de que, em tais convenções, é impossível distinguir - e menos ainda separar - o interesse social da pessoa jurídica do interesse individual dos acionistas" (Validade e Eficácia de Acordo de Acionistas. Execução específica de suas estipulações in Novos Ensaios de Direito empresarial, cit., p. 67). Em semelhante linha de argumentação, cf. CARNEIRO DA FRADA ("Acordos Parassociais "Omnilaterais" - Um novo caso de "desconsideração" da personalidade jurídica?", in Direito de Sociedades em Revista. ano I, vol. 2, Outubro de 2009, p. 98), em que se examina "se e até que ponto um acordo parassocial que inclua ou englobe todos os sócios de uma sociedade comercial pode soprepor-se a regras jussocietárias".

${ }^{284}$ Até porque, como já esclarecido, acima, nesses casos ela pode ser considerada parte (= centro de interesses) do contrato parassocial. 
forma que o terceiro por ela atingido conheça a imunidade de que goza o contrato em questão, com a finalidade precípua de desautorizá-lo a alegar ignorância de seus termos.

Tratando-se, todavia, de situação em que as partes dos dois negócios em confronto são, em última análise, as mesmas, a regra de oponibilidade quer parecer desnecessária: pela boa-fé que deve prevalecer entre os acionistas, não seria racionalmente possível à companhia alegar total desconhecimento de determinado ajuste parassocial, obtendo-se, na prática, resultado equivalente ao buscado pela regra de oponibilidade ${ }^{285}$.

Com relação a terceiros, assim, não há que se falar em oponibilidade dos preceitos do contrato parassocial de cunho patrimonial que tenha por escopo outras estipulações que não a compra e venda de ações e preferência.

Havendo conflito entre a posição jurídica de um terceiro e determinadas disposições constantes do contrato parassocial, ser-lhe-ia autorizado alegar desconhecimento do ajuste, o qual é naturalmente privado do poder de sujeitar terceiros a seus termos (i.e, o oposto do que ocorre em casos de oponibilidade).

Pela outra faceta da oponibilidade, não haveria na hipótese qualquer poder formador que pudesse servir de óbice à plena realização da posição jurídica do terceiro.

\footnotetext{
285 Ainda Comparato, sobre casos de identidade total entre os signatários do pacto parassocial e os acionistas da companhia, informa que "[a] regra excepcional da desconsideração da personalidade jurídica tem, aí, inteira aplicação, tratando-se, como se trata, de evitar que o formalismo da aparência possa ser invocado para a elusão do cumprimento de obrigações de colaboração ou de confiança recíproca e a fidelidade societária" (Validade e Eficácia de Acordo de Acionistas. Execução Específica de suas estipulações, in Novos ensaios... cit., p. 67), tendo antes asseverado que "[s]eria contrário ao mais elementar princípio da boa-fé societária vir aquela companhia, por meio de outros diretores, não signatários (...) alegar desconhecimento do pacto acionário. A função de notificação da pessoa jurídica, ínsita na formalidade do arquivamento do acordo na sede da companhia, foi, no caso, realizada pela presença de controladores e diretores desta, como partes na convenção de voto. Pois mais "realidade" que se queira emrestar à pessoa coletiva, é bem de ver que a "ciência" e "vontade" desta confundem-se com a ciência e a vontade do seus controladores e representantes legais" (COMPARATO, Validade $e$ Eficácia..., cit., p. 65-66).
} 
Nesse sentido, pode-se cogitar que, ao adquirir ações vinculadas a pacto parassocial que prevê outras prestações a seu titular, o terceiro de boa-fé, com relação a elas, não se subrogaria automaticamente na posição jurídica de seu predecessor, ao contrário do que ocorre com relação às obrigações e ônus ligados à compra e venda de ações e preferência ${ }^{286}$.

Por essa razão, é comum que se preveja cláusulas de sucessão nos pactos parassociais patrimoniais, mediante as quais o acionista signatário que vender sua participação acionária obriga-se a transferir ao comprador das ações também a sua posição contratual no pacto. Tratando-se muitas vezes, contudo, de obrigações intuitus personae, a alteração da parte no pacto parassocial patrimonial pode mudar o contexto societário a que ele se refere.

Esse é, ao menos, o conjunto do que se pode extrair da análise da doutrina brasileira sobre o alcance do art. 118, que enxerga a oponibilidade dos acordos de acionistas - e não de pactos parassociais - centrada nos ajustes de voto e de compra e venda, originalmente constantes do texto legal.

Diante dessas considerações, conclui-se que (i) acordos relativos ao exercício do direito de voto e/ou do poder de controle são oponíveis à companhia, que não pode fugir à observância de seus termos; (ii) acordos sobre compra e venda de ações e preferência para adquiri-las são oponíveis a terceiros, uma vez averbados nos livros da companhia, afastando eventuais negócios jurídicos entabulados em desrespeito ao acordo. A companhia tem ciência desses acordos e não deve registrar transferências de ações que os contrariem; (iii) ajustes relativos a outras matérias não são oponíveis à companhia e/ou a terceiros. Em caso de acordo firmado por todos os acionistas, essa afirmação deve ser mitigada pela necessária observância da boa-fé, que impede à companhia de alegar desconhecimento dos termos contratados em sede parassocial.

\footnotetext{
286 Nesse sentido: "a transferência das ações, gravadas com estipulações de acordo de acionistas regularmente registrados, importa a automática transferência de deveres, ônus e responsabilidades estipulados nesses pactos" (idem, p. 84).
} 


\section{4 - Produção de efeitos reflexos.}

Frente às conclusões apontadas para o tema da oponibilidade, verificase que é no campo da produção de efeitos reflexos a partir de pactos parassociais patrimoniais que repousa a maior relevância para o argumento que norteia esta tese.

Se é pacífico que os pactos parassociais, em regra e à exceção dos acordos de acionistas, não são oponíveis à companhia e/ou terceiros, daí não se pode deduzir, diretamente, que por isso, eles não sejam capazes de afetar sobremaneira suas esferas jurídicas e, por sua própria função econômica, não tenham o condão de impactar seja o relacionamento societário entre as partes, seja, mediatamente, as relações entre a companhia e terceiros como credores, outros acionistas e todos os stakeholders.

Conforme já se mencionou, aos contratos aplica-se o princípio da relatividade de seus efeitos, no sentido de que o vínculo contratual gera direitos e obrigações, relativos às prestações avençadas, apenas para as partes contratantes ${ }^{287}$.

Há, porém, outros efeitos derivantes do contrato que não se limitam às prestações concordadas. Como fato, o contrato gera efeitos na esfera jurídica de terceiros alheios à estipulação, podendo tanto beneficiá-los como lesá$\operatorname{los}^{288}$. São os chamados efeitos reflexos da contratação.

\footnotetext{
287 Na síntese de Vincenzo Roppo, o princípio de relatividade dos contratos assume significados positivos e negativos. São postulados positivos do princípio (i) o fato de que contrato não impõe obrigações (tais como contratadas) a terceiros, (ii) o contrato não pode subtrair direiros de terceiros, o que não significa que não tenha o condão de violar direito de terceiros e (ii) o contrato não pode impedir terceiro de adquirir um direito (Il contratto, Milano, Giuffrè, 2001, pp. 566-7).

${ }^{288}$ Com relação à amplitude do princípio da relatividade dos contratos e a seus significados negativos, ROPPO esclarece que ele não faz com que "o terceiro seja imune a qualquer consequência fática do contrato inter-alios. É bem possível que um contrato tenha, de fato, consequências muito relevantes para terceitos a ele estranhos" ("il terzo sia immune da qualsiasi conseguenza fattuale derivante dal contratto inter-alios. È ben possibile che un contratto abbia, di fatto, conseguenze anche molto rilevanti per terzi estranei ad esso"), afirmando ainda que "o princípio nem mesmo impede que o contrato lesione não apenas
} 
A própria oponibilidade (antes comentada) e o regime de publicidade ligam-se a essa preocupação, na medida em que alertam possíveis terceiros sobre contratos que podem afetar sua esfera jurídica.

Além disso, não se pode olvidar que, ao incidir sobre a relação contratual parassocial, a boa-fé objetiva faz surgir às partes deveres em face de terceiros, expandindo a eficácia contratual ${ }^{289}$.

Cabe então avaliar essas considerações com relação a contratos parassociais patrimoniais. No Capítulo 2, examinou-se sua função econômica, em base a suas principais ocorrências, tendo se assentado que esses contratos têm por causa determinante a integração e moldagem da disciplina global do relacionamento societário que as partes querem ver desenvolvido, formatando o estado de sócio de cada qual.

simples interesses, mas verdadeiros e próprios direitos ou posições juridicamente protegidas do terceiro" ("[i]l principio neppure impedisce che il contratto leda non già semplici interessi, ma veri e propri diritti o comunque posizioni giuridicamente protette del terzo". Il Contratto, cit., p. 564). Da mesma forma, aponta que surgem ao terceiro deveres de respeito à posições contratuais das partes, originadas pelo contrato (idem, p. $565)$.

289 Luciano de Camargo Penteado anota que a regra do art. 422 do Codigo Civil Brasileiro aplica-se inicialmente às partes contratantes, em vista do que é contratado (efeito inter-partes). Noticia, porém, que no direito comparado se compreende que alguns contratos ostentariam "eficácia de proteção ao terceiro, derivada justamente da cláusula geral de boa-fé". (Efeitos Contratuais... cit. p. 177). Nesse sentido, convém transcrever o entendimento de MAnUel A. Carneiro Da Frada: "Qualquer contacto humano e, deste modo, também aquele que se estabelece no âmbito de uma relação contratual, potencia riscos de interferências danosas na integridade pessoal ou patrimonial dos intervenientes. (...) Em foco está a defesa de posições jurídicas que não foram abrangidas no programa contratual livremente estipulado pelas partes mas que podem ser afectadas durante a sua execução. Quando assim acontece, o dano produzido é independente do interesse de cumprimento e fala-se então da ocorrência de danos acompanhantes ou paralelos (Begleitenschaden; Parallelschaden). (...) Um relance, ainda que rápido, sobre os diversos comentários ao código civil alemão permite logo identificar um largo espectro de decisões nas quais a jurisprudência germânica, desenvolvendo praeter legem o sistema juridico sobretudo com amparo do $\$ 242$ (cláusula de boa-fé), reconheceu a violação de deveres conexos com o contacto contratual mas insusceptível de desencadear a aplicação das regras gerais do incumprimento porque alheia à relação de prestação" (Contrato e deveres de proteção, Coimbra, Almedina, 1994, p.143). Cf. ainda, Judith Martins-Costa, Da Boa-fé no Direito Privado, São Paulo, RT, 2000, pp. 437-454 e Menezes Cordeiro, Da Boa Fé no Direito Civil, Coimbra, Alamedina, 2011 pp. 604-615. 
O próprio relacionamento societário gera efeitos perante terceiros, razão pela qual o direito societário deve tutelar suas posições jurídicas ${ }^{290}$. Se os contratos parassociais - e em especial, os patrimoniais - estruturam esse relacionamento, sua capacidade de afetar os mesmos terceiros alvo de tutela pelo direito societário deve ser apreciada.

Com relação aos ajustes relativos à compra e venda, não é difícil pensar em efeitos reflexos da pactuação perante eventuais acionistas não signatários, credores dos sócios e da companhia e outros terceiros, não obstante, repise-se mais uma vez, esses contratos sejam mais comumente avaliados apenas sob a perspectiva do vínculo obrigacional criado entre as partes.

Efetivamente, as condições de compra e venda estipuladas podem fazer com que acionistas não signatários vejam sua participação política enfraquecida, diante de alterações no quadro social.

De outro lado, acordos de compra e venda que isentam o acionista vendedor do risco do empreendimento levado a cabo pela sociedade pode ser considerado leonino e, assim, danoso frente aos demais acionistas que não contam com esse suposto privilégio.

Pense-se, ainda, em contratos de compra e venda de participações que exponham a companhia a danos em face da retirada de acionista fundamental ao negócio ou, ainda, nas hipóteses de dano ao credor pessoal do sócio, mascaradas em contratos de compra e venda de participações pelos quais o acionista abre mão das ações integrantes de seu patrimônio em circunstâncias desfavoráveis ao credor.

Além disso, são variadas as hipóteses de efeitos reflexos produzidos, junto a terceiros, por acordos prevendo obrigações acessórias dos acionistas, incluindo a não concorrência. Por exemplo, o acordo de fornecimento de

\footnotetext{
${ }^{290}$ Exemplos são as regras sobre representação da sociedade perante terceitos e aquelas relativas à composição e proteção do capital social.
} 
matéria prima de um acionista para a sociedade atinge não apenas ela mas, mediatamente, também outros acionistas que não sejam signatários do acordo mas que, é claro, participam dos benefícios ou prejuízos decorrentes da atividade social em que esses insumos são empregados. Em outro exemplo, o pacto de não concorrência pode gerar efeitos substanciais no mercado de atuação da companhia, atingindo reflexamente os acionistas não signatários e terceiros.

Em conclusão, é inegável que, não obstante os pactos parassociais patrimoniais tenham por objeto direitos patrimoniais individuais dos signatários, podem gerar efeitos sobre terceiros não contratantes, exigindo que sua interpretação considere a capacidade de afetar os alvos de tutela do direito societário (e.g. credores, outros acionistas).

\section{5 - Execução específica}

Como já se salientou, ao lado da oponibilidade a outra peculiaridade conferida aos acordos de acionistas pelo art. 118 seria o direito a execução específica ${ }^{291}$ das disposições, quando arquivado na companhia.

Por execução específica entende-se a possibilidade de se obter, por via judicial, prestação idêntica àquela que se teria se o devedor houvesse

\footnotetext{
${ }^{291}$ Lei 6.404 , art. 118 da $\S 3^{\circ}$ : “Nas condições previstas no acordo, os acionistas podem promover a execução específica das obrigações assumidas". Cabe esclarecer que não se tem por objetivo aprofundar o exame da execução especifica de pactos parassociais, ou mesmo de acordo de acionistas, tema bastante explorado na doutrina brasileira. Cf., assim, José Alexandre Tavares Guerreiro, Execução Específica de Contratos de Acionistas, in RDM, n. 41, Janeiro/Março de 1981; André Cavalcanti De Albuquerque Abbud, Execução específica dos acordos de acionistas, São Paulo, Quartier Latin, 2006; ANTONIO Carlos Monteiro Da Silva Filho, Ação para Execução Específica de Acordo de Acionistas, Dissertação de Mestrado apresentada ao Departamento de Direito Processual da Faculdade de Direito da Universidade de São Paulo, 1999; Celso Barbi Filho, Acordo de acionistas: panorama atual do instituto no direito brasileiro e propostas para a reforma de sua disciplina legal, in RDM 121 2001, pp. 30-55; Celso BARBI Filho, Efeitos da reforma do Código de Processo Civil na execução específica do acordo de acionistas, in RDM 109, 1998, pp. 17-38, José IGNÁCIO Botelho DE MESQuita, Execução específica de Direito de Preferência Originado de Acordo de Acionistas in AAVV, Temas de Direito Societário e Empresarial Contemporâneos - Liber Amicorum Prof. Dr. Erasmo Valladão Azevedo e Novaes França, São Paulo,Malheiros, 2011, pp. 836-848.
} 
cumprido o acordo. Ou seja, trata-se da obtenção da prestação exatamente como estabelecida entre as partes, e não uma indenização pelo descumprimento ${ }^{292-293}$.

No Brasil, a execução específica de obrigações juridicamente infungíveis já constava do Código de Processo Civil ao tempo da promulgação da Lei $6.404 / 76^{294}$ e, atualmente, o tema é tratado nos artigos 466-A e 466-B do diploma processual ${ }^{295-296}$.

${ }^{292}$ Explica JosÉ ALEXANDRE TAVARES GUERREIRO, que “[n]a verdade, a nosso ver, o que
qualifica a execução específica como tal é o objeto sobre o qual recaem as providências de
satisfação do credor da obrigação ou, sob outra perspectiva, a natureza satisfativa de tais
providências. No centro da problemática estudada, localiza-se a possibilidade da satisfação
in natura, de direitos exigíveis (id est, bens juridicamente tutelados), sem a
alternatividade de remédios compensatórios. O suprimento judiciário objetivado pela
execução específica atua concretamente no sentido da vontade contratual, expressa no
acordo. Consequentemente, a composição da lide, no caso, não se traduz em reparaçóes, de
suposta equivalência indenizatória; ao contrário, deve assegurar o cumprimento em espécie
das estipulações ajustadas" (Execução Específica de Contratos de Acionistas. cit., p.45). ${ }^{293}$ Quanto aos tipos de execução, vale transcrever a lição de CELSO BARBI FILHo: “[a] execução por quantia certa é sempre específica, pois nela busca-se o cumprimento da obrigação de pagar um débito. Fora essa hipótese, a execução específica está basicamente ligada às obrigações de dar, fazer e não fazer. A execução específica da obrigação de dar é em regra possível, desde que a coisa exista. A de não fazer viabiliza-se quando o ato não tenha sido praticado. Já a de fazer depende de a prestação ser fungível (exemplo: construir um muro), naturalmente infungível (exemplo: fazer um show) ou juridicamente infungível (exemplo: prestar declaração de vontade). As obrigações fungíveis podem ser executadas especificamente por terceiros, em procedimento regulado do Código de Processo Civil, correndo os custos a cargo do inadimplente. As naturalmente infungíveis só podem ser prestadas pelo próprio devedor, eventualmente persuadido mediante mecanismos de pressão de vontade, como multas etc., aprimorados da Reforma do Código de Processo Civil de 1994. Se mesmo assim o devedor permanecer inadimplente, só restam perdas e danos. Já as obrigações juridicamente infungíveis têm mecanismo próprio para execução específica, que é o suprimento judicial da vontade não manifestada voluntariamente. E são as obrigações de fazer juridicamente infungíveis, ou seja, prestar declaração de vontade (voto) e concluir contrato (compra e venda de ações). Que interessam aos acordos de acionistas, cuja sede para execução específica está nos arts. 641 e 639 do Código de Processo Civil, respectivamente" (Acordo de Acionistas: Panorama atual do instituto no Direito Brasileiro... cit. p. 49).

${ }^{294}$ Anteriormente, a sistemática da execução específica era tratada pelo Código de Processo Civil nos artigos 639 e 641, vigentes desde sua instituição pela Lei $\underline{5.869,}$ de 11 de janeiro de 1973 , portanto, anteriores à Lei de S.A..

${ }^{295}$ Os artigos 466-A e 466-B do CPC foram acrescidos pela Lei 11.232 de 22.12.2005 e substituíram, respectivamente, os antigos artigos 641 e 639 revogados pela mesma Lei.

${ }^{296}$ Os artigos que tratam de execução específica de obrigações juridicamente infungíveis dispõem: "Art. 466-A. Condenado o devedor a emitir declaração de vontade, a sentença, uma vez transitada em julgado, produzirá todos os efeitos da declaração não emitida. Art. 
Examinando, pois os artigos acima citados, conclui-se que as obrigações infungíveis são passíveis de execução específica quando forem promessas de prestar declaração ou de concluir contrato; no primeiro caso, a sentença transitada em julgado produzirá todos os efeitos da declaração não emitida, já no segundo, produzirá os efeitos do contrato não concluído.

Por consequência qualquer contrato ou obrigação que se enquadre nessas hipóteses é passível de execução específica, ou seja, a possibilidade de obter-se a execução específica de um contrato deriva unicamente das disposições previstas no Código de Processo Civil. Nessa esteira, o, art. 118, $\S 3^{\circ}$ da Lei 6.404 apenas reforça a possibilidade de execução específica do acordo de acionistas ${ }^{297-298}$.

Quando se fala em execução específica de acordo de acionistas, tanto a legislação quanto a doutrina voltam-se à compra e venda de ações, à preferência para adquiri-las e ao exercício do direito de voto ${ }^{299}$, cujas

466-B. Se aquele que se comprometeu a concluir um contrato não cumprir a obrigação, a outra parte, sendo isso possível e não excluído pelo título, poderá obter uma sentença que produza o mesmo efeito do contrato a ser firmado.

297 Celso BARBi FILho entende que “[o] art. 118, §3º, da Lei de S/A dispõe que as obrigações constantes dos acordos de acionistas têm execução específica, mas isso é uma redundância, de vez que elas o teriam por força da lei processual. Assim, improcede o entendimento de que os acordos com objetos extravagantes aos vistos no art. 118 não sejam passíveis de execução específica” (idem, ibidem).

298 No mesmo sentido, Modesto CARvalhosa, in verbis "Mesmo que não houvesse a expressa referência à execução específica na lei societária ( $\$ 3^{\circ}$ art. 118), os regulares acordos de acionista sobre votos (e controle e minoritário) e de compra e venda de ações, que configura um pré-contrato, sempre poderão ser passíveis da medida judicial ou arbitral, nos termos dos referidos arts. 466-A, 466-B e 466-C do Código de Processo Civil" (Acordo de Acionistas, cit., p. 365) e LUIS GASTÃo PAES DE BARROS LEÃES: “Irrelevante porque, em verdade, o legislador de 1976, ao contemplar a seção V do cap. X (art. 118 e $\S \S)$ ao acordo de acionistas, compreendendo, além do nomen juris, as partes, o objeto e, ainda, a solutio, não produziu nenhuma regra relativa à actio, fazendo uma remissão à lei processual. Como ponderou Antônio Carlos de Araújo Cintra, a inserção do $\S 3^{\circ}$ no art. 118, que simplesmente diz que os acionistas podem promover a execução específica das obrigações, nas condições previstas no acordo, seria dispensável, já que não introduziu nenhuma regra adjetiva diversa daquela prevista no art. 639 do CPC, que, em si, é plenamente aplicável à espécie" (Pactos Parassociais. Natureza jurídica... cit. pp. 44).

${ }^{299}$ Celso BARBi Filho expõe, justamente, sobre quais tipos de acordo recaem os estudos: "Não obstante a possibilidade da existência de acordos com outros objetos que não os enunciados no texto da lei societária, é inegável que o maior interesse prático e usual volta-se sobre aqueles acordos que tenham objetos típicos, ou seja, a compra e venda de 
disposições nos pactos são, usualmente, tratadas como obrigações de contratar e prestar declaração de vontade, respectivamente.

Todavia, cumpre esclarecer que não necessariamente todas as modalidades de acordos que derivam das matérias previstas no art. 118 da Lei de S.A., serão passíveis de execução específica. Isso porque, com a sofisticação dos ajustes firmados entre sócios, um acordo que envolva, por exemplo, compra e venda de ações, pode ainda assim não preencher os requisitos do art. 466- ${ }^{300}$. É possível, ainda, que em alguns casos peculiares, a eventual execução específica não atenda, afinal, aos objetivos buscados pelos sócios ${ }^{301}$.

De outro lado - o que se mostra mais relevante para a reflexão proposta neste trabalho - um pacto parassocial patrimonial mesmo que fundado em matérias que não se incluem naquelas previstas no art. 118 da lei 6.404/76, pode ser passível de execução específica, desde que, frise-se, envolva obrigação de emitir declaração de vontade ou promessa de $\operatorname{contratar}^{302}$.

A existência de disposição expressa no art. 118 , $\S 3^{\circ}$ da Lei de S.A. apenas confere maior grau de certeza quanto à possibilidade de execução

ações, a preferência para adquirí-las e o exercício do direito de voto. Tais ajustes implicam, em última análise, pactuação de obrigações de contratar e de prestar declaração de vontade" (Efeitos da Reforma do Código de Processo Civil... cit., p.24).

${ }^{300}$ Um contrato de compra e venda de ações pode conter, por exemplo, uma cláusula de arrependimento, o que o impossibilitará de ser executado especificamente. Cf. José Alexandre Tavares Guerreiro, Execução Específica de Contratos de Acionista... cit., p. 50 .

301 Celso Barbi Filho explica que as dificuldades impostas pela execução específica do acordo de acionistas frente à dinamicidade das relações societárias, levam os pactuantes a buscar meios alternativos para solucionas eventuais controvérsias, in verbis: "Para se evitar os percalços e as dificuldades de uma execução específica judicial do acordo de acionistas, a prática societária tem consagrado a previsão contratual de meios de saída do pacto para os casos de inadimplemento, sistema que muitos advogados consideram o melhor instrumento de preservação da avença" (Acordo de Acionistas: Panorama atual do instituto no Direito Brasileiro... cit., p. 49).

302 “O campo de aplicação da chamada execução específica está nas obrigações de dar coisa certa, de não fazer, e de fazer, estas últimas quando juridicamente infungíveis. Tais obrigações, portanto, quando objeto de acordo de acionistas, serão passíveis de execução específica" (CElso Barbi Filho, Efeitos da Reforma do Código de Processo Civil... cit. p. $37)$. 
específica de acordos de acionistas, sobretudo quando se tem em mente a preocupação do legislador societário em conferir aos acordos de voto eficácia social ${ }^{303}$.

Qualquer outro contrato, inclusive pacto parassocial, que se revista de promessa de emitir declaração de vontade (art. 466-A do CPC) ou preveja promessa de contratar (contrato preliminar) (art. 466-B do CPC) é também plenamente passível de execução específica,

Conclui-se assim que na mesma medida em que é válida e eficaz a celebração de contrato entre acionistas com objeto que não esteja previsto em Lei $^{304}$, esse acordo poderá ser executado especificamente, desde que preencha os requisitos dos arts. 466-A e 466-B do $C P C^{305}$.

Ou seja: pelo menos um dos efeitos do art. 118 da Lei de S.A. - a execução específica não é, em verdade, prerrogativa exclusiva dos pactos ali previstos.

\section{6 - Pactos parassociais patrimoniais e outras categorias contratuais.}

Caracterizados os pactos parassociais patrimoniais quanto a sua função econômica e examinada a disciplina legal, é preciso analisá-los com vistas às

\footnotetext{
${ }^{303}$ Nesse sentido André de Albuquerque Cavalcanti Abbud comenta que “[a] expressa previsão dessa possibilidade em relação aos acordos de acionistas, contudo, adveio para espancar as dúvidas que antes da vigência da Lei de Sociedades Anônimas ainda permeavam a nossa doutrina e jurisprudência, acerca da possibilidade de se obter o cumprimento específico das obrigações contidas notadamente os de voto" (Execução Específica dos Acordos de Acionistas, cit. p. 114).

${ }^{304}$ Repisando o argumento em confronto com o tema da execução específica, verifique-se as posições Celso Barbi Filho, Efeitos da Reforma do Código de Processo Civil... cit, pp. 23-24) e André de Albuquerque Cavalcanti Abbud Execução Específica... cit., p. 106).

305 Sem contar, ainda, que a obtenção de resultado processual específico é expressão da garantia constitucional da ação, como sintetiza André DE AlbuQuerQue CAVALCANTI ABBUD: "[e]m verdade, essa norma da lei societária nem precisaria existir. A oferta de tutela jurisdicional apta a conceder a quem tenha um direito, tudo aquilo e precisamente aquilo a que faça jus - de que constitui exemplo a tutela específica -, é mesmo conteúdo da garantia constitucional da ação ( $\mathrm{CF}$, art $5^{\circ}$, inc. XXXV), tal como concebida pela visão moderna e instrumentalista do processo civil”. Idem, p. 113).
} 
diversas categorias dogmáticas que neles se imbricam em virtude de aspectos peculiares a esse tipo de contratação e à função econômica que desempenham.

3.6.1- Contrato plurilateral com comunhão de escopo. Contratos de longa duração, relacionais, incompletos ou de colaboração.

Tomado o caráter duradouro da relação societária alvo dos pactos parassociais, é preciso notar que eles também são celebrados na perspectiva de sua duração por longo tempo (normalmente, pelo menos enquanto as partes permenecerem sócias).

Como consequência, os pactos parassociais patrimoniais ostentam disposições normativas, regulamentadoras das múltiplas ocorrências que podem ou mesmo devem ser verificadas naquele relacionamento societário.

Nesse sentido, os pactos parassociais assentam-se na colaboração que deve existir entre os sócios como base fundamental de qualquer relacionamento societário ${ }^{306}$.

É em vista dessa colaboração, portanto, que são celebrados e devem ser interpretados os pactos parassociais patrimoniais, em que pese haver manifestações na doutrina no sentido de neles não se enxergar base colaborativa. Essa posição é tomada, contudo, quando se analisa apenas o objeto mediato do pacto - a alienação de participações societárias, por exemplo - e não a relação societária em que se insere e o papel que nelas desempenha.

Os pactos parassociais podem ser alinhados à categoria de contratos plurilaterais com comunhão de escopo tendo em conta que, por meio deles seus celebrantes formulam ditames para seu relacionamento societário ${ }^{307}$. Com

\footnotetext{
${ }^{306}$ Esse aspecto será tratado no Capítulo 4.

${ }^{307}$ Cabe anotar, todavia, que não há identidade com os contratos associativos, na leitura a eles proposta por PAOLO FERRO-LuzzI, visto que esses últimos têm em mira a criação de uma organização e não a previsão de direitos subjetivos. Nos contratos parassociais, as
} 
esse intento, valem-se seja de acordos de voto que de pactos com os mais diversos conteúdos patrimoniais, como já se apontou.

$\mathrm{Na}$ doutrina o caráter plurilateral é frequentemente apontado com relação apenas aos acordos de votos, mas ele não deve ser afastado, de plano, daqueles patrimoniais ${ }^{308}$. Nesse ponto, parece haver confusão de conceitos, diante da complexidade do fenômeno.

Como será adiante explorado, o contrato parassocial - plurilateral - é moldura para que operações concretas, que podem ter caráter bilateral, (como a compra e venda de ações de um acionista a outro) realizem-se.

Como é cediço, o caráter plurilateral de um contrato é caracterizado pela possibilidade de sobrevida do contrato mesmo diante da ruptura do vínculo com uma das partes e pela previsão de regras e obrigações vinculantes àquele grupo, em vista de um escopo comum, e não de parte a parte, como sucede nos contratos bilaterais sinalagmáticos.

$\mathrm{Na}$ perspectiva que se adota nesta tese, os contratos parassociais patrimoniais aproximam-se mais de contratos plurilaterais, ainda que algumas prestações possam ter caráter bilateral (ex.: pactos prevendo prestações específicas a apenas uma das partes) ${ }^{309}$. Isso porque, sem desviar demais o

partes buscam regular seus direitos relativos a essa organização (sociedade). Seria possível porém aproximar as noções quando se fala de pactos parassociais celebrados antes mesmo da constituição da companhia em que se mescla, portanto, o objetivo de criação da organização com aquele de regulamentação do exercício direitos das partes enquanto sócias. Cf. Paolo Ferro-Luzzi, Milano, Giuffré, 1976 e Marcio Ferro Catapani, Os Contratos Associativos, in ERASmo VAlladẽo AZEvedo E Novaes FrançA (Coord.), Direito Societário Contemporâneo - I, São Paulo, Quartier Latin, 2009, pp.87-103 (especialmente pp. 92-93).

${ }^{308}$ Sustentando a bilateralidade dos acordos de compra e venda e bloqueio cf. a posição de Carvalhosa, Comentários... pp. 553-554; 558-559 e 564 e RAFFAEle Torino ("I sindacati di blocco, a differenza dei sindacati di voto non constituiscono contratti plurilaterali con comunione di scopo". I Nuovi Contratti nella prassi civile e commerciale, Torino, UTET, 2004, p. 188).

309 Precisa a análise de Celso BARBi Filho: “[p]ara Modesto Carvalhosa só o acordo de voto tem a natureza parassocial e plurilateral. O acordo de bloqueio seria contrato tipicamente bilateral, de caráter patrimonial, com prestações sinalagmáticas, que admitem exceção de não cumprimento. Embora repute correta a observação de nosso maior Mestre 
enfoque, é preciso anotar que os variados ajustes de caráter patrimonial são reunidos em único instrumento normativo das relações societárias entre os signatários na medida em que as prestações não se exaurem de parte a parte, mas referem-se àquele relacionamento, àquele grupo de sócios que assim quis disciplinar sua convivência.

Como será adiante esclarecido, as categorias contratuais em jogo, tratando-se de pactos parassociais patrimoniais, não têm entre si divisão rígida, no sentido de que referidos pactos ostentam características de mais de uma delas que, por isso, não se excluem.

A doutrina ainda não é uníssona, reconhecendo a plurilateralidade aos acordos de voto e insistindo, por vezes, no caráter bilateral dos acordos de bloqueio, nos quais muitos pactos parassociais patrimoniais incluem-se, ainda que em muitos casos (como nos contratos de investimento ou nos acordos de associação ou "joint venture") sejam efetivamente plurilaterais e permaneçam vigentes mesmo quando uma das partes deixa de participar da avença ${ }^{310}$.

no assunto, penso que pode estar presente a plurilateralidade no acordo de bloqueio, na medida em que o objetivo da restrição de transferência das ações é comum a vários acionistas, e pode ser violado por apenas um deles, sem prejuízo de permanência e exigibilidade quanto aos demais" ("Acordo de Acionistas: panorama atual do instituto no direito brasileiro e propostas para a reforma da disciplina legal in $R D M 121$, p. 36).

${ }^{310}$ A discussão sobre o caráter bilateral ou plurilateral de ajustes parassociais impacta a admissibilidade, por consequência, das variadas hipóteses de seu término, especialmente quanto a possibilidade de denúncia. Na doutrina brasileira dos últimos anos, esse aspecto tem sido amplamente discutido e, considerando não ser fulcral para os argumentos desta tese, não será aprofundado. Confira-se, assim, Luis GASTÃo PAES DE BARRos LEÃes, Resolução de acordo de acionistas por quebra de affectio societatis, in in AAVV, Temas de Direito Societário e Empresarial Contemporâneos - Liber Amicorum Prof. Dr. Erasmo Valladão Azevedo e Novaes França, São Paulo, Malheiros, 2011, pp. 443-452; MARIA ISABEl DE Almeida AlvarengA, Impossibilidade de resilição unilateral de acordo de acionistas por prazo indeterminado (comentário ao acórdão do Tribunal de Justiça do Estado de São Paulo na Apelação Cível n. 211.924.1/4), in RDM 108, 1997, pp. 186-96; CELSO BARBI FILHo, Acordo de acionistas: panorama atual do instituto no direito brasileiro e propostas para a reforma de sua disciplina legal, in RDM 121, 2001, pp. 3055; Modesto CARvalhosa, Acordo de acionistas, in RDM 106, 1997, pp. 20-24; MAURicio Moreira Mendonça De Menezes, Resolução de acordo de acionistas com base na quebra da affectio societatis (comentário ao acórdão do Superior Tribunal de Justiça no Recurso Especial n. 388.423-RS), in RTDC, n. ${ }^{\circ} 23,2005$, pp. 141-67 e WALD, Arnoldo, Do cabimento da denúncia vazia de acordo de acionistas firmado por prazo indeterminado, 
Prosseguindo no mesmo raciocínio, os pactos parassociais patrimoniais não podem ser examinados, pois, como contratos de intercâmbio com execução instantânea. Ao contrário, agrupam-se melhor, ainda que não perfeitamente ${ }^{311}$, entre os contratos de colaboração ou relacionais $s^{312}{ }^{313}$.

Tomando as características dos contratos relacionais, ao menos duas delas podem ser identificadas nos contratos parassociais patrimoniais: eles tendem a se protrair no tempo e disciplinam, portanto, questões futuras entre as partes.

\section{6 .2 - Contratos incompletos}

A mesma ordem de fatores que aproxima os pactos parassociais patrimoniais da categoria dos contratos relacionais e/ou de colaboração faz com que possam ser vistos como contratos incompletos, tal como propostos pela doutrina alinhada ao law and economics.

São contratos incompletos aqueles que "não contêm - e não podem mesmo conter - a previsão de todas as vicissitudes que serão enfrentadas pelas partes" ${ }^{314}$.

especialmente nos casos de inadimplemento e de má-fé da outra parte ou de conflito de interesses superveniente (Parecer), in RDCv n $\mathrm{n}^{\circ} 78,1996$, pp. 151-75

${ }^{311}$ O encaixe não é perfeito pelo fato de os contratos parassociais referirem-se a um relacionamento que, por si só, já se baseia na colaboração, i.e., os sócios já devem colaborar entre si por estarem ligados por vínculo societário. O contrato parassocial apenas integra e modela esse vínculo. Ao contrário, a análise doutrinária dos contratos relacionais enfoca a colaboração de agentes econômicos em princípio independentes que, por força do contrato, passam a ostentar certa interdependência. A aproximação feita no presente trabalho, por isso, não tem a pretensão de atestar a total identidade entre conceitos, mas apenas evidenciar aspectos que podem ser aproveitados para melhor configuração e tratamento dos pactos parassociais patrimoniais.

312 Terminologia consagrada de IAN MCNEIL, The relational theory of contract: Selected Works of Ian Macneil, London, Sweet \& Maxwell, 2001.

313 Cf. Junqueira De Azevedo: "O acordo de acionistas é contrato de colaboração. à semelhança das parcerias. (...); em terminologia atual, de influência norte-americana, por ser de longa duração e exigir colaboração constante, pode ser classificado como "contrato relacional' (Novos estudos e Pareceres, cit. p. 124).

${ }^{314}$ Entendimento de Paula A. Forgoni, que informa, ainda, com base em Antonio Nicita e VinCENZO SCOPPA, que o contrato seria completo ao estabelecer as obrigações das partes 
Também os contratos parassociais patrimoniais enfrentam, pois, algumas daquelas que são apontadas como causas de incompletude contratual, como a impossibilidade de previsão do futuro e a imprecisão dos termos do acordo, frequentemente amplos e “abertos" 315.

Por consequência, as partes igualmente estão sujeitas à necessidade de repactuação em vista de situações ou eventos não previstos, aos quais mesmo os termos amplos e as "válvulas de escape" previstas no instrumento do contrato podem não ser bastantes para o deslinde do impasse ${ }^{316}$.

\title{
3.6.3- Contratos-quadro
}

Os contratos parassociais patrimoniais abrigam, ainda, características dos chamados contratos-quadro.

Na dicção de Junqueira DE AZEvedo, o contrato-quadro

\begin{abstract}
"pode ser definido como aquele que busca fixar algumas das principais regras às quais se submeterão os contratos pontuais a serem futuramente celebrados pelas partes; o contrato quadro visa criar um quadro único para governar o conjunto das relações continuadas entre os contratantes" ${ }^{317}$.
\end{abstract}

Os ajustes parassociais de caráter patrimonial, convém repisar, raramente são objeto de variados instrumentos apartados e específicos para cada ajuste. Ao contrário, o mais comum é que se redija instrumento único, em que as partes incluirão todos os pactos que desejam observar em seu

para cada situação possível atual ou futura que teriam seu respeito garantido por autoridade externa, com aplicação de sanções pelo inadimplemento (Teoria Geral dos contratos empresariais, cit. p. 71).

315 Cf. idem, p. 72 e RaChel Sztajn e Haroldo Duclerc Verçosa, A incompletude do contrato de sociedade, in RDM 131, 2003, pp. 7-20.

316 Cf. Paula A. Forgioni, Teoria... cit., p. 72 e, sua fonte, Giuseppe Bellantonio, I contratti incompleti nel diritto e nell'economia, p. 75.

317 (parecer) Contrato-quadro. Impossibilidade superveniente da obrigação de celebração dos contratos de execução (compra e venda) por inexistência de critério consensual para estipulação do preço. Inadmissibilidade de arbitramento judicial do preço. Resolução ex nunc dos Contratos-quadros e restituição do enriquecimento sem caus in Novos Estudos e Pareceres de Direito Privado, São Paulo, Saraiva, 1a. Edição, 2a . Tiragem, 2010, p. 167. 
relacionamento, ou seja, incluem desde acordos de voto até os pactos patrimoniais ora comentados.

Por consequência, esse contrato único (geralmente intitulado, na prática internacional, como "General Agreement" ou "Shareholders'Agreement) acolhe e enuncia as regras que devem ser seguidas pelas partes no curso de sua convivência, ditando critérios para as futuras contratações e/ou operações que serão realizadas sob sua égide.

O instrumento contratual que abriga esses ajustes, por si, tem caráter de moldura geral e mais ampla, enquanto os pactos nele contidos (ex: acordos sobre compra e venda de ações) oferecem a moldura relativa, especificamente, às operações de compra e venda que as partes poderão levar a termo.

Em ambos os casos, reitera-se o caráter programático seja dos pactos, seja do instrumento contratual que os contém ${ }^{318}$.

\subsection{4 - Contratos normativos}

Outra classificação doutrinária à qual podem se alinhar os contratos parassociais patrimoniais, na esteira do que foi dito sobre os contratosquadro, é a de contratos normativos.

Segundo RoPPo, contratos normativos são aqueles com os quais as partes definem cláusulas de futuros contratos, gerando a obrigação de incluilas se e quando eles forem celebrados ${ }^{319}$. Por consequência, prestam-se a declarar ou conformar uma situação jurídica preexistente.

\footnotetext{
${ }^{318} \mathrm{Na}$ literatura, encontra-se ainda a expressão "acordo guarda-chuva", sob o qual vários outros ajustes ou pactos são celebrados. A dinâmica, todavia, é diversa, no sentido que, na noção de contrato guarda-chuva, acentua-se o aspecto de coligação de vários contratos a um elemento causal comum, embora não se esteja a tratar do estabelecimento, como ocorre no contrato-quadro, de termos gerais dentro dos quais os variados pactos devem ser celebrados (i.e. a moldura contratual).

319 in verbis: "I contratti normativi sono i contratti con cui le parti definiscono le clausole di futuri contratti. Da essi nasce l'obbligo di inserire tali clausole nei futuri contratti, se e quando saranno conclusi”. Il contratto, cit., p. 526
} 
Ainda segundo o autor, os contratos normativos apresentam subtipos, dentre os quais os contratos normativos internos, verificados quando as partes do contrato normativo e do contrato a ser celebrado são as mesmas.

Espécie de contrato normativo interno é, justamente, o contrato-quadro acima referido ${ }^{320}$, enquanto contrato normativo externo é aquele que prevê condições de contratação a serem observadas pela parte ao firmar contrato com terceiro (e.g. contrato de distribuição estabelece condições que o distribuidor deverá observar no contrato de venda do produto ao consumidor final).

\section{7 - Conclusões. Proposta de definição de pactos parassociais patrimoniais e utilidade do subgrupo proposto.}

Os pactos parassociais patrimoniais, cumprindo função econômica de moldar o relacionamento societário verificado entre seus signatários, apresentam características que os alinham em subgrupos contratuais diversos e, de certa maneira, complementares, em vista de apresentarem, de um lado, caráter colaborativo, longa duração e incompletude - resultando na sua inclusão junto dos contratos relacionais - e, de outro lado, o caráter programático/normativo de suas disposições - aproximando-os dos contratosquadro.

Diante do exposto no capítulo 2 e neste capítulo 3, pode-se propor a seguinte definição de trabalho para os pactos parassociais patrimoniais: tratase de ajustes celebrados entre sócios de sociedades anônimas fechadas, em um ou vários instrumentos contratuais diversos dos estatutos sociais, tendo por objeto direitos patrimoniais individuais de cada parte, com o fim de integrar e modelar o regime do relacionamento societário entre elas existente e, assim, informar o estado de sócio de cada um dos signatários.

${ }^{320}$ Cf. Idem, ibidem. 
Do ponto de vista dogmático, ostentam características, seja do subgrupo dos contratos de colaboração/relacionais que daquele dos contratos normativos, incluídos os contratos-quadro.

Os contratos parassociais patrimoniais tanto podem conter matérias específicas dos acordos de acionistas previstos no art. 118 da Lei de S.A (ou seja, compra e venda e preferência) como abarcar outras matérias relevantes para o relacionamento societário que as partes buscam desenvolver.

No primeiro caso, beneficiam-se da oponibilidade de suas disposições; em ambos os casos, poderão ser executados de forma específica, quando atenderem aos requisitos da legislação processual, em que pese a redação do art. 118 dar a entender que somente o que está ali inscrito tem execução específica.

A utilidade que se pretende obter, com a definição e caracterização ora realizadas, é a de evidenciar as peculiaridades desses ajustes para sua adequada interpretação, consentânea com sua função econômica. Partindo dessas peculiaridades, passa-se ao exame de elementos que devem ser considerados no processo interpretativo. 


\section{4. - ELEMENTOS PARA INTERPRETAÇÃO DOS PACTOS PARASSOCIAIS PATRIMONIAIS NO DIREITO SOCIETÁRIO BRASILEIRO}

"En vertu du principe de liberté contractuelle, les actionnaires
devraient pouvoir disposer de leurs droits individuels comme
ils l'entendent. La realité est plus nuancée"
MICHEL GERMAIN ${ }^{321}$

Nos capítulos anteriores, procurou-se caracterizar os pactos parassociais patrimoniais evidenciando a sua função econômica de instrumento fundamental à estruturação e definição da relação societária existente entre as partes signatárias, ainda que afetem, imediatamente, apenas a esfera jurídica dos celebrantes.

Todo contrato parassocial, explicou-se, é firmado por sócios tendo em mira direitos e obrigações relacionados às suas posições jurídicas fundadas nessa qualidade, para a melhor disciplina de seu relacionamento.

Ou seja, muito embora os contratos parassociais patrimoniais sejam regrados pela teoria geral dos contratos, eles encontram-se, necessariamente, insertos em uma relação entre sócios.

Assim, pergunta-se: essa circunstância exige do intéprete qualquer inflexão no processo hermenêutico normalmente realizado com relação a contratos em geral ou mesmo outros contratos empresariais não baseados em uma relação societária?

Esse questionamento é a pedra angular dos argumentos que serão desenvolvidos a respeito da interpretação dos pactos parassociais patrimoniais, objeto final da presente tese.

\footnotetext{
${ }^{321}$ atualizador do clássico Traité de Droit Commercial de RIPERT e Roblot, cit., p. 397.
} 


\section{1 - Pressuposto essencial ao exame da interpretação: pactos parassociais e sua intrínseca ligação com a relação societária.}

Ao decidirem-se pela celebração de contrato de sociedade ${ }^{322}$, as partes têm em vista os elementos intrínsecos e essenciais desse contrato, e sua causa/função econômica: a reunião de esforços e recursos em prol de um fim comum, com divisão dos resultados obtidos (positivos ou não).

Apresentam, pois, a intenção de associar-se para o atingimento desse escopo comum e, tratando das sociedades a que se refere no presente trabalho, essa intenção ostenta caráter intuitus personae, ou seja, cada uma das partes contratantes não apenas tem intenção de se associar, como a tem em vista e por conta de determinadas características das demais.

Celebrado o contrato social (ou aprovado o estatuto social), convém frisar, duas ordens de efeitos são geradas.

De um lado, nasce a sociedade ("Verband") enquanto ente que desenvolverá o objeto assinalado pelas partes e, nas sociedades anônimas e nas sociedades limitadas, a inscrição no registro do comércio faz surgir sua personalidade jurídica, que se desprende da pessoa dos seus sócios.

De outro lado - e é aqui o ponto nevrálgico para a tese - surge o vínculo societário entre as partes, que passam a ser sócios ${ }^{323}$, partícipes de uma relação duradoura ${ }^{324}$ em vista de um escopo comum ${ }^{325}$.

\footnotetext{
322 A afirmação procede ainda que se tenha em mente a concepção institucionalista da sociedade, pois segundo a melhor doutrina há sempre um contrato plurilateral entre as partes, que origina a pessoa jurídica/instituição.

${ }^{323}$ A exemplo do que se verificava na redação do art $1^{\circ}$ do Decreto 2.627/40, neste trabalho adota-se sinonímia entre os termos sócio e acionista (cf. a respeito, TRAJANO MIRANDA VAlverde, Sociedade por ações, Forense, Rio, vol. I, p. 75-76). Esta opção é tomada para enfatizar o relacionamento societário entre as partes, ainda que o mais tecnicamente correto, no caso de sociedades anônimas fechadas, fosse acionista. Abre-se mão de utilizar a expressão por ela ligar-se igualmente aos acionistas de sociedades de capital aberto, em que o vínculo societário entre as partes é ínfimo se comparado àquele que se tem em mente neste trabalho. Sobre a diversidade da configuração da posição jurídica de sócio nos diversos tipos societários, cf. Menezes CoRDEIRO, Manual... cit., p. 498.
} 
Esse liame, a seu turno, faz brotar entre as partes um plexo de direitos e deveres que não têm apenas origem legal ou estatutária ${ }^{326}$ : decorrem mesmo da própria noção de sociedade e da lógica inerente a esse contrato, calcada em sua função econômica, a exemplo do dever geral de colaboração mútuo (em vista da busca pelo fim comum) e do dever de lealdade ${ }^{327}{ }_{-}^{328}$.

Insistiu-se em sublinhar, nos capítulos iniciais, o fato de ser sempre mais comum que, cientes desse liame que os liga e procurando detalhar melhor as regras do relacionamento que deve se desenvolver entre eles em vista de

324 Cf. Menezes Cordeiro, Manual.., cit., pp.515-521, para “o status de sócio como situação duradoura”.

${ }^{325}$ Na sempre acurada explanação de Menezes Cordeiro, tem-se que "quando duas ou mais pessoas se encontram com um projeto societário, elas actuam em duas vertentes: assumindo obrigações umas para com as outras; fixando um quadro de organização que, depois, irá desenvolver novas actuações produtivas. O modo por que se conectem esses dois substratos é variável. Teoricamente, o substrato obrigacional será máximo nas sociedades civis puras, vindo a diminuir sucessivamente nas sociedades em nome colectivo, por quotas e anónimas. Também teoricamente, esse mesmo substrato varia na razão inversa do substrato organizacional" (Manual..., cit., p. 179). No presente trabalho, já se apontou, tem-se em mira sociedades anônimas fechadas, em que, precisamente, o substrato obrigacional a que o autor se refere é acentuado.

${ }^{326}$ A boa-fé na execução do contrato de sociedade é fonte de deveres autônomos dos sócios para com os demais. Cf. GiUseppe Alberto Rescio, La distinzione del sociale dal parasociale in Rivista delle Società, p. 628. Referência no tema das relações fiduciárias entre acionistas, cf. ERICH FECHNER, Die Treubindung des Aktionärs. Zugleich eine Untersuchung über das Verhältnis von Sittlichkeit, Recht und Treue, Hermann Böhlaus Nachfolger, Weimar, 1942. Na síntese de MENEZES CoRDEIRo, “[o]s direitos patrimoniais e os participativos dos sócios não esgotam o teor do estado de sócio. Os sócios encontramse, ainda, imersos numa teia de diretos e deveres mútuos. Além disso, surgem tutelas indiretas e diversas outras posições ativas" (Manual... cit., p. 512). V., ainda, posição já externada de DALMARTELlo.

327 Tópicos que serão explorados no item 4.5, infra.

328 Adota-se a posição de que mesmo em sociedades anônimas - sobretudo fechadas, alvo desta tese - há o dever de lealdade entre os acionistas, eis que noção fundamental à perseguiçào próprio escopo comum, ínsito a toda sociedade. Nesse ponto ampara-se em COMPARATO, para quem "[e]m toda sociedade, estabelece-se um quadro geral de relações entre os sócios, fundadas na fidelidade e confiança recíprocas. É a affectio ou bona fides societatis. Esse relacionamento especial de boa-fé e de verdadeiro intuitus personae pode existir na sociedade anônima fechada, notadamente a que conta, complementarmente ao estatuto, com acordo particular entre todos os acionistas (...). (Restrições à circulação de ações... cit., p. 49). 
seus peculiares interesses, os partícipes da relação societária celebrem pactos parassociais $^{329}$.

Pois bem. Os pactos parassociais são celebrados em função daquele liame, daquele vínculo existente entre as partes a que linhas antes se referia, que buscam personalizar. Por consequência, encontram-se inegavelmente "submersos" naquele conjunto de direitos e deveres que decorrem desse mesmo vínculo, ainda que não expressos na lei ou no estatuto. De outro lado, aquilo que as partes acordam parassocialmente passa a integrar o mesmo conjunto de direitos e deveres; passa a compor o estado de sócio de cada um dos celebrantes ${ }^{330}$.

Tomada essa perspectiva, a atração da disciplina societária aos pactos parassociais não decorreria assim, necessária e exclusivamente de qualquer efeito que possa ter na sociedade (= pessoa jurídica) ou de seu caráter organizativo/político e sim por decorrência lógica da própria noção de sociedade e da função econômica que os pactos parassociais - em especial os patrimoniais - desenvolvem sobre a relação jurídica existente entre os signatários.

O contrato parassocial patrimonial nada mais seria que um instrumento contratual que complementa a disciplina da mesma relação gerada pelo contrato de sociedade ou, ainda, informa os caracteres dessa relação antes mesmo da gênese da sociedade. Na medida em que essa contratação integra e

\footnotetext{
${ }^{329}$ Como se viu, os pactos parassociais podem dizer respeito ao exercício de direitos de sócio que acabem por afetar a organização e o funcionamento da companhia, notadamente quando fundados nos direitos políticos, mas igualmente podem ter por objeto direitos patrimoniais dos sócios que, em princípio, não afetariam a sociedade enquanto pessoa jurídica distinta. Em ambos os casos, plasmam e impactam o relacionamento societário entre as partes.

${ }^{330}$ Cf. nota número 31 .
} 
influencia a relação societária entre os celebrantes, o direito societário é chamado a intervir ${ }^{331}$.

Por "atração da disciplina societária", esclareça-se, não se pretende provocar qualquer aproximação do contrato parassocial às regras relativas ao estatuto social, formalidades e demais regras cogentes ligadas à organização da pessoa jurídica.

O que se quer dizer, apenas, é que as regras e princípios societários voltados ao relacionamento, ao vínculo existente entre sócios devem ser observados, ainda que o contrato parassocial seja patrimonial. Ou seja, ainda que tenha por objeto direito individual do acionista, gerando efeitos, em princípio, apenas entre as partes contratantes, porém em vista de sua relação societária. A realidade sobre a qual incidem os pactos parassociais é, pois, mais nuançada e complexa, como advertiu Michel Germain na citação que abre este Capítulo.

Adiante serão examinadas as principais consequências das reflexões ora empreendidas sobre a indefectível ligação do contrato parassocial patrimonial não tanto com o estatuto social, mas com a relação societária que advém da contratação de sociedade e da intenção das partes em concluí-la.

\section{2 - Segundo pressuposto: real alcance da teoria geral dos contratos nos pactos parassociais patrimoniais}

Esclarecida a inserção dos pactos parassociais (patrimoniais ou não) no contexto da relação societária entre as partes, é hora de evidenciar o alcance da teoria geral dos contratos nos pactos parassociais patrimoniais.

\footnotetext{
${ }^{331}$ Tendo em vista que "[o] Direito das sociedades ordena e legitima o funcionamento das realidades de que se ocupa. Ele disciplina as relaçóes que se estabelecem entre os sócios e assegura a eficácia erga omnes da actuação societária. Regula os bens sociais. Assegura a administração e a representação. Em suma: dá corpo à existência e ao funcionamento das sociedades” (Menezes CordeIro, Manual.., cit., p. 167. Grifou-se).
} 
O esforço é necessário porque, como muito já se afirmou neste trabalho, encontra-se repetidamente, na doutrina nacional e estrangeira, menções ao fato de que os contratos parassociais são submetidos às regras gerais sobre contratos, sem que maiores esclarecimentos sobre o real significado de afimações desse gênero sejam tecidos.

Da análise aprofundada e comparada das obras que trataram do assunto ${ }^{332}$, pode-se, entretanto, extrair conclusões mais precisas ao se colocar o problema sob o prisma da inserção do pacto social na relação societária.

De fato, a preocupação central dos que inicialmente cuidaram dos contratos parassociais era a de evidenciar a distinção desses contratos frente aos contratos ou estatutos sociais ${ }^{333}$.

Nessa ótica, salienta-se que os contratos parassociais - porque não se igualam aos estatutos e desempenham outro papel - teriam sua estipulação regrada pela teoria geral dos contratos e não pelas regras societárias, quer dizer, pelas regras incidentes sobre a estipulação do contrato ou estatuto social que, sabe-se, são bastante restritivas da autonomia contratual ${ }^{334}$.

Tomada a leitura nesses quadrantes, não se pode concluir, ainda que obliquamente, que os contratos parassociais não devam respeito ao direito societário ou a preceitos próprios da lógica societária ${ }^{335}$.

\footnotetext{
332 Sobretudo Cf. Giorgio Oppo, Contratti... cit.; Luigi Farenga, I contratti... cit.; Giuseppe SAntoni, Patti parasociali. cit. e Yves GuYon, Les sociétés, cit.. No direito brasileiro os vários textos de Barbi Filho, Carvalhosa, Albuquerque Barreto, Leães, e Comparato, referidos no Prólogo.

${ }^{333}$ Cf. crítica de CRISTINA CERONi, constante da nota 79.

334 Sobretudo quanto à função de estruturar pessoa jurídica (quando há separação patrimonial) e/ou prever os termos da responsabilidade dos sócios, em ambos os casos em vista da proteção de terceiros.

${ }^{335}$ Incisivas e precisas, nesse ponto, as palavras de MARTINA PAIARDini ao comentar que a indiferença do pacto para a sociedade não equivale a indiferença para a lei, tendo em vista que a causa societária se realiza sobretudo entre os sócios e não apenas perante eles e a sociedade (in verbis: "[1]'indiferenza del patto per la società non equivale a indiferenza per la legge, poiché l'ordinamento può sanzionare anche il patto non coinvolgente la società, dato che la causa sociale deve realizzarsi anche ed anzittutto tra i soci e non solo
} 
Simplesmente ocorre que os requisitos de validade dos contratos e estatutos sociais não precisam ser observados quanto aos pactos parassociais ${ }^{336}$, não obstante se tratar de pactuação ligada à mesma base, que é o relacionamento societário entre os signatários.

Outro aspecto que contribui para a incorreta análise do tema é o fato de, em regra, os efeitos jurídicos dos pactos parassociais serem apenas obrigacionais e não sociais (ou reais, diretamente incidentes sobre a vida social, superando a solução por perdas e danos).

Como se apontou no capítulo 3 , a doutrina é enfática em ressaltar que os efeitos dos contratos parassociais verificam-se em nível contratual e não societário.

Trata-se, afinal, de aplicação do princípio de separação entre a sociedade e seus sócios ${ }^{337}$, pois, na presença do "schermo" da pessoa jurídica ${ }^{338}$, o que o acionista contrata parassocialmente não pode vincular $a$ companhia ou seus órgãos, exceto nos casos previstos de maneira bastante singular no art. 118 da Lei 6.404/76.

De outro lado, no mesmo raciocínio, o inadimplemento do que foi acordado parassocialmente (ex. prestação acessória) não geraria, per se, qualquer efeito social direto, como por exemplo a suspensão do direito de

tra questi e la società". Sui pressuposti di configurabilitá del divieto di patto leonino, in Riv. Dir. Comm., 2011,1, p. 109).

336 Cf. Giuseppe Alberto Rescio, La distinzione del sociale dal parasociale (sulle c.d. clausole statutarie parasociali in Rivista delle Società, 1991, p. 596- 656. Em especial, o autor aponta as diversas ocorrências da separação e contraposição entre o negócio social e o parassocial nos planos: (i) da constituição; (ii) da validade; (iii) da eficácia; (iv) da interpretação e (v) da modificação de cada um dos negócios. (p. 599-600).

${ }^{337}$ Nos comentários da lei acionária alemã enfatiza-se, ao analisar os acordos parassociais, o fato que a eles se aplica o princípio da separação entre sociedade e acionistas ("Trennungsprinzip"). Cf., por exemplo, Comentários ao §23, VöLKER RÖHRICHT in KLAUS J Hopt e Herbert Wiedemann (org.), Aktiengesetz Großkommentar, Berlin, De Gruyter Recht, sd., Rdn 238;

338 Terminologia de FRANCESCO GALGANO (La società e lo schermo giuridico della personalità giuridica, in Giurisprudenza Commerciale 1, 1983, pp. 5 e 16). 
voto do acionista inadimplente, como ocorreria, no direito brasileiro, se a estipulação constasse do estatuto social (art. 120 Lei 6.404/76). Ao contrário, apenas as consequências obrigacionais, conforme tenham sido convencionadas (multas, penalidades), seriam, em princípio, impostas ao faltoso ${ }^{339}$.

Dessas afirmações não decorre, contudo, que a ausência de efeitos sociais aos signatários afaste a necessária coerência dos contratos parassociais patrimoniais ao direito societário - no sentido de que devem respeito aos fundamentos e princípios que incidem sobre a relação societária alvo da pactuação, como adiante se verá.

Mais uma vez é preciso frisar que Oppo examinou o problema com base na dualidade de negócios jurídicos, ainda que interligados ${ }^{340}$, quando aqui se foca a unicidade do relacionamento societário estruturado seja nos estatutos sociais, seja nos contratos parassociais e é verificada pela composição do estado de sócio dos celebrantes, o qual inclui tanto as disposições legais e estatutárias como também aquelas parassocialmente estipuladas ${ }^{341}$.

Em resumo: mesmo tendo por objeto direitos individuais que não incidem sobre a organização da sociedade, os pactos parassociais patrimoniais são celebrados por sócios em função de um relacionamento societário e, portanto, mesmo que se valham do direito comum dos contratos para sua estipulação, não podem ser examinados como um negócio jurídico totalmente

\footnotetext{
339 Como se antecipou no Capítulo 2, ao examinar justamente caso envolvendo pacto parassocial patrimonial, COMPARATO advoga, todavia, dando sustentação ao raciocínio que se busca desenvolver nesta tese, que se o inadimplemento do que foi contratado envolve violação de dever de colaboração inerente às relações societárias, seria possível a suspensão de direitos prevista no art. 120 da lei 6.404/76, quando não fosse possível a medida mais drástica de exclusão de sócio: "as leis acionárias de alguns países, inclusive do nosso, consagram outro remédio societário adequado a sancionar as violações dos deveres de colaboração de acionistas, em função do interesse comum. É a suspensão do exercício dos direitos societários (Lei $\mathrm{n}^{\circ}$ 6.404, de 1976, art. 120). Restrições à circulação..., cit., pp. 41-42. Essa posição - que liga o inadimplemento do pacto parassocial ao desrespeito a dever de acionista, ensejando suspensão de direito de voto e, assim, efeito social - não é muito enfatizada na doutrina.

${ }^{340}$ Cf. Oppo, Contratti..., cit. p. 30 e ss.

${ }^{341}$ Cf. uma vez mais, Menezes Cordeiro, (Manual.., cit., p. 507).
} 
a ele alheio ou mesmo um contrato celebrado entre partes que entre si não guardem uma relação de colaboração ${ }^{342}$.

Ou, em outras palavras, os contratos parassociais patrimoniais são regulados pelo direito comum dos contratos, mas na sua interpretação devem ser consideradas as preocupações societárias que levaram as partes a celebrálos (que refletem sua função econômica) e as diretrizes do direito societário voltadas à tutela desse relacionamento e de terceiros por ele afetados.

\section{3 - O papel da interpretação para os pactos parassociais patrimoniais}

Diante da ausência de regra específica, no direito brasileiro, sobre os limites de validade dos pactos parassociais ou mesmo de indícios para sua compreensão como categoria dogmática, a proposição de elementos para a interpretação desses negócios jurídicos assume papel primordial para que se obtenha maior grau de segurança jurídica na verificação, a posteriori, seja de sua licitude ${ }^{343}$, seja de sua consonância com a intenção comum das partes e a função econômica por elas desejada ${ }^{344}$.

\footnotetext{
342 Cf. Comparato, Restrições à circulação de ações em companhia fechada: Nova et Vetera, in Novos ensaios... cit., p. 50.

${ }^{343}$ De maneira geral, Géraldine GoffauX-Callebaut sugere que os pactos relativos ao capital devam respeitar dois princípios importantes: a circulabilidade das ações e o direito de restar associado, os quais serão tratados mais adiante. Todavia, como se verá da explanação que segue, a necessidade de conjugar os aspectos da teoria geral dos contratos com fundamentos societários pode apontar outros elementos a orientar o intérprete ( $D u$ Contrat..., cit., p. 251).

${ }^{344}$ Francisco Paulo de Crescenzo Marino eclarece que "todo negócio jurídico deve ser interpretado. A demonstração dessa assertiva é simples. Por meio da interpretação, determina-se o conteúdo do negócio jurídico, qual seja, o conjunto dos preceitos ou regras que dele emanam, quer sejam expressos ou declarados, isto é contidos na declaração negocial, quer sejam implícitos ou não declarados. Outrossim, é comum afirmar que interpretar um negócio jurídico é determinar o seu sentido ou significado. Ora, todo negócio jurídico tem (ou pode ter) conteúdo (ou sentido)" (Interpretação do Negócio Jurídico, São Paulo, Saraiva, 2011, p. 65).
} 
Contudo, como já ressaltou PaUla A. Forgioni, muito embora o tema da intepretação dos negócios empresariais ${ }^{345}$ seja de fundamental importância para a segurança e previsibilidade necessárias ao bom funcionamento do mercado e das instituições, pouca atenção lhe tem sido destinada no Brasil ${ }^{346}$ ${ }^{347}$, muito em virtude da pretensão positivista da clareza absoluta do texto contratual ${ }^{348}{ }^{349}$.

No raciocínio da autora, também contribui para os poucos avanços doutrinários no campo da intepretação dos contratos empresariais na doutrina brasileira o fato de ser algo recente a discussão sobre a existência de contratos que não se encaixam nos moldes do contrato de intercâmbio (em que prestação e contraprestação se exaurem com o adimplemento; e onde o lucro de uma parte é o prejuízo da outra) ${ }^{350}$ e que, portanto, requerem interpretação diferenciada.

Como se apontou no Prólogo, já se tem desenvolvido, no Brasil, linha de análise dos contratos comerciais como grupo especial em virtude do fato de

\footnotetext{
345 Importante ressaltar que mesmo entre sócios não sendo necessariamente empresarial, uma vez que a relação entre sócios tem por escopo seus direitos em uma sociedade empresária, a lógica empresarial atinge a contratação.

346 "Quem observa a doutrina do direito mercantil depara-se com fenômeno peculiar: no mais das vezes, pouca ou nenhuma importância dá-se à atividade de interpretação dos negócios empresariais, como se a letra do instrumento existisse por si só, e por si só fosse capaz de disciplinar a relação formatada pelos agentes econômicos nos amplos quadrantes da autonomia privada" (PAUlA A. Forgioni, Teoria Geral dos Contratos Empresariais, cit., p. 215).

347 FRANCISCO MARINO também anota, a respeito do "desprestígio" das regras de interpretação, que "frequentemente o valor das normas jurídicas intepretativas não é objeto do merecido reconhecimento. Isso se deve à antiga posição - infelizmente até hoje dotada de seguidores - de acordo com a qual tais normas teriam natureza de "meros conselhos ou sugestões', sem a imperatividade das demais normas jurídicas" (Interpretação..., cit., p. 71).

348 “o repúdio dogmático à atividade interpretativa é injustificável e perigoso, desaguando - ao contrário do que criam os antigos - no aumento do grau de insegurança e imprevisibilidade jurídicas" (PAUla A. FORGIOni, Apontamentos sobre algumas regras de interpretação dos contratos comerciais: Pothier, Cairu e Código Comercial de 1850, in RDM 141, Janeiro-Março/2006, p. 40).

${ }^{349}$ Cf. crítica de Tullio Ascarelli em Norma giuridica e realtà sociale - in Problemi giuridici, tomo I, Milano, Giuffré, pp. 85 e ss..

${ }^{350}$ Paula A. Forgioni, Teoria Geral... cit., p. 215.
} 
que sua interpretação deve ser pautada por vetores peculiares à sua função econômica e à sua inserção na ordem jurídica do mercado, não obstante seu regramento legal ser o comum a outros grupos de contratos ${ }^{351}$.

Trazendo o argumento para o campo dos contratos parassociais patrimoniais, ainda não se encontram estudos, no Brasil, em que a mesma proposta é avaliada ou desenvolvida, muito embora essa reflexão seja relevante para o avanço científico no direito societário pois, como pontua José Alexandre Tavares Guerreiro,

"[o] tema da interpretação domina o estudo dos grandes problemas na vivência do direito societário, principalmente porque nessa província há limites peculiares à especialíssima natureza e à função da companhia - à sua estruturação como agente econômico, em uma palavra. Por variados motivos, a interpretação dos atos e negócios pertinentes ao direito das sociedades refoge, não poucas vezes, ao domínio geral do direito privado" ${ }^{352}$.

Como exemplo dessa necessidade, tem-se que as disposições legais sobre contratos de intercâmbio não são plenamente aplicáveis aos contratos parassociais patrimoniais mesmo quando, como se viu no capítulo 2 , o pacto parassocial preveja a compra e venda de ações ou outras modalidades de alienação de direitos ${ }^{353}$, ou seja, ainda que como resultado final do pactuado exsurjam contratos de intercâmbio (a compra e venda em si). Ao contrário também se espera ter esclarecido no Capítulo 2 - o pacto parassocial patrimonial traz características de um contrato de longa duração porque duradoura a relação a que ele se refere e justamente pelo fato de sua função econômica fundar-se na disciplina e definção dessa mesma relação.

\footnotetext{
${ }^{351}$ Cf. os pioneiros trabalhos da Profa. PAula A. Forgioni já citados: Teoria Geral dos Contratos Empresariais; Apontamentos sobre algumas regras de interpretação dos contratos comerciais: Pothier, Cairu e Código Comercial de 1850 e Interpretação de negócios empresariais no novo Código Civil Brasileiro (RDM, n. 130, p. 7-38).

352 Interpretação de Preferências..., cit., p. 389.

353 Sobretudo em razão da já comentada concepção individualista dos direitos de propriedade.
} 
Como resultado, à exceção de menções esparsas e artigos pouco divulgados ${ }^{354}$, não se encontrou, na pesquisa empreendida, estudos sistemáticos sobre as regras gerais que devem informar a interpretação dos pactos parassociais patrimoniais no direito brasileiro, considerando as particularidades ora descritas, o que lança o desafio de tratar do tema, mesmo sabendo-se não ser possível, de um só lance, esgotá-1o ${ }^{355}$.

É preciso verificar, pois, condicionantes que influenciam a intepretação dos pactos parassociais patrimoniais, tomando-se por base o raciocínio descrito no item 4.1, acima, em que se evidencia sua íntima relação com o liame societário existente entre os celebrantes.

Em situações similares, o estudioso poderia se voltar à contemplação sistemática da jurisprudência que, com relação ao negócio jurídico sob exame, tivesse se formado ${ }^{356}{ }_{-}^{357}$.

No Brasil, todavia, também a jurisprudência é incapaz de indicar caminhos seguros para a interpretação dos pactos parassociais patrimoniais.

Isso porque, as decisões jurisprudenciais brasileiras centram-se, sem surpresa, em aspectos próprios dos acordos de acionistas caracterizados no capítulo anterior. Ou seja, não há uma perspectiva sobre o gênero dos pactos parassociais, patrimoniais e políticos, mas a ênfase na sua principal espécie, no direito brasileiro ${ }^{358}$.

\footnotetext{
${ }^{354}$ Por exemplo, um dos raros artigos alinhados com a proposta é da lavra de MAURICIO Moreira MENDONÇA DE MEnezes, Resolução de acordo de acionistas... cit., em que comenta a decisão no Recurso Especial n. ${ }^{\circ}$ 388.423-RS (caso Petroplastic), singular decisão judicial a enfrentar o tema com viés mais aproximado ao adotado nesta tese.

355 Reitera-se mais uma vez que não se tem a pretensão de aclarar todos os múltiplos aspectos que podem derivar da enunciação de alguns elementos e critérios válidos para a interpretação dos contratos sob exame.

356 cf. GuYON, Les sociétés... cit., p. 308-309.

357 A exemplo de estudos como os de Paula A. Forgioni, Contrato de Distribuição, São Paulo, RT, 2005 e LuCiano De CAMARgo Penteado, Efeitos Contratuais.. cit.

${ }^{358}$ Cf. seção AnÁlises JuRisprudenciais.
} 
Não bastante essa dificuldade, a colheita de dados é comprometida pelo fato de que, sempre mais, questões empresariais complexas são submetidas à arbitragem e, assim, ao correspondente sigilo. É verdade que esse não é um problema verificado apenas no direito brasileiro, tendo em vista a crescente expansão da arbitragem empresarial no contexto internacional.

Todavia, aliado à ausência de disciplina legal sobre o conjunto dos pactos parassociais, esse aspecto intensifica a insegurança jurídica que cerca o tema. Mesmo a doutrina é afetada pela impossibilidade de avaliação e discussão dos grandes casos em que o assunto é abordado, freando-se o desenvolvimento de estudos a ele $\operatorname{ligados}^{359}$.

Em resumo: do que se sustentou até o momento, pode-se apontar como premissas fáticas, no direito brasileiro, para o estudo do processo de interpretação dos pactos parassociais patrimoniais: (i) a ausência de regra legal específica sobre validade, determinando a verificação a posteriori; (ii) a ausência de jurisprudência consolidada e conhecida, dificultando estudos sistemáticos; (iii) o foco sobre a espécie acordo de acionistas; (iv) a complexidade das estruturas em que, frequentemente, os pactos parassociais patrimoniais são incluídos e (v) a sua celebração típica em sociedades anônimas fechadas e/ou sociedades limitadas, em que a relação entre as partes é destacada ${ }^{360}$.

É nesse cenário que ora se procura apontar elementos para a interpretação dos pactos parassociais patrimoniais, tomando por pressupostos

\footnotetext{
${ }^{359}$ Conforme já referido e a maioria dos julgados foca questões processuais, como pode ser demonstrado na seção ANÁlises JURISPRUDENCIAIS, que contém os parâmetros de pesquisa utilizados e a porcentagem de temas encontrados. Não se obteve, igualmente, decisões relevantes do exame dos anuários da ICC (International Chamber of Commerce), como já se salientou.

${ }^{360} \mathrm{Na}$ hoje clássica lição de COMParato, “[a] 'sociedade anônima de pessoas' em especial, está longe de ser aquele 'mecanismo jurídico'descrito por Ripert. Ele não existe longe e fora do acordo personalíssimo das partes, a modo de um deux ex machina que vive e age autonomamente, livre da vontade e dos interesses que o engendraram. Por detrás do véu do anonimato enxerga-se a realidade concreta dos sócios, com suas intenções, palavras e obras" (Novos Ensaios e Pareceres..., p. 40).
} 
teóricos a sua celebração por partícipes de uma relação societária, adstritos por direitos e deveres decorrentes dessa mesma relação, gerada pelo contrato de sociedade (item 4.1, acima) bem como o real alcance da teoria geral dos contratos na sua apreciação (item 4.2).

Nessa linha, procurar-se-á atender à lição de Eros ROBERTo GraU, ao enunciar três das mais importantes pautas intepretativas recomendadas pela prudência: “(i) a primeira relacionada à interpretação do direito no seu todo; (ii) a segunda, à finalidade do direito; (iii) a terceira, aos princípios" ${ }^{361}$.

\section{4 - Elementos da tradicional teoria da interpretação dos negócios jurídicos}

Como primeiro passo na tentativa de enunciação de elementos para a interpretação dos pactos parassociais patrimoniais, cumpre voltar aos clássicos para obter ferramentas úteis ao processo.

Como relembra PAUla A. Forgioni, o direito brasileiro assistiu ao evoluir da fixação das regras para a interpretação contratual a partir da sistematização levada a termo por PothiER, em 1761, chegando ao art. 131 do Código Comercial de 1850 e à sua derrogação formal pelo Código Civil de $2002^{362}$.

\footnotetext{
${ }^{361}$ Ensaio e Discurso sobre a interpretação/aplicação do Direito. $3^{\mathrm{a}}$ Ed. Malheiros, São Paulo, 2005, p. 39. O autor, em trecho anterior, esclarece ser a interpretação do direito "uma prudência - o saber prático, a phrónesis, a que refere Aristóteles" e, por consequência, com escólio em COMPARATO, "o intérprete atua segundo a lógica da preferência, e não conforme a lógica da consequência: a lógica jurídica é a da escolha entra várias possibilidades corretas" (Ensaio... cit., p. 35)".

${ }^{362}$ Ainda com apoio em Francisco MARino, nota-se que o Código Civil de 2002 manteve a linha do Código Civil de 1916 em prever poucas regras de interpretação (incluindo o art. 113), posição elogiada por parte da doutrina quando comparada com a posição de outros ordenamentos em que as variadas regras de interpretação incluídas no texto legal acabaram por ser consideradas na jurisprudência como meros "conselhos" (Interpretação... cit. p. 71). Contudo, como se apontou acima, à época de vigência do Código Civil de 1916 a interpretação dos negócios empresariais tinha sua orientação complementada pelas disposições do Código Comercial o que, ao menos formalmente, não mais ocorre. Nesse sentido a crítica de PAUla A. Forgioni de que "o código brasileiro afastou-se de sua
} 
A relevância dessas regras, explica a autora, liga-se à sua capacidade de reunir em enunciados lógicos o que a prática mercantil demandava (e ainda demanda), tendo em conta "o fluxo de relações econômicas e a principal função do direito comercial, motivo mesmo de sua gênese: dar condições para o melhor funcionamento possível do mercado" ${ }^{363}$.

Considerando a discussão que ora se pretende aprofundar sobre condicionantes à interpretação dos pactos parassociais patrimoniais algumas dessas regras devem ser avaliadas ${ }^{364}$.

\subsection{1 - Interpretação conforme a intenção comum das partes: função} econômica do contrato. Contexto negocial e espírito do contrato.

A primeira enunciação de Pothier aponta que

$$
\begin{aligned}
& \text { "nas convençós mais se deve indagar qual foi a intenção } \\
& \text { commum das partes contrahentes, do que qual he o sentido } \\
& \text { grammatical das palavras" } 365
\end{aligned}
$$

Seguindo a posição de Paula A. Forgioni, fundada em Betti, ao questionar qual a intenção comum das partes deve-se apurar, em verdade, qual a função econômica que as partes buscaram obter com a pactuação e, por consequência, qual a racionalidade jurídica que deve orientar a intepretação

declarada fonte de inspiração e - o que é muito pior - de nossa tradição, corporificada no Código Comercial" (Apontamentos sobre algumas regras... cit., p. 34).

${ }^{363}$ Idem, p. 33.

${ }^{364} \mathrm{O}$ que não significa que as demais regras lançadas por POTHIER e/ou transcritas no Código Comercial não sejam aplicáveis aos pactos parassociais patrimoniais, enquanto negócio jurídico como qualquer outro. O que se procura, aqui, é evidenciar aquelas regras que mais impactam a interpretação dos pactos parassociais patrimoniais, em vista da argumentação que se procura realizar.

${ }^{365}$ Conforme salienta PAula A. Forgioni, ligam-se à primeira regra de Pothier também a décima, undécima e duodécima regras, todas voltadas à busca da intenção das partes quando da celebração de um negócio. A sexta regra aponta a necessidade de interpretação das cláusulas contratuais com base no negócio global, que serve a uma função econômica única (cf. Teoria Geral dos Contratos Empresariais, cit. pp. 225-227). 
do negócio, considerando aquilo "que, no mercado, normalmente se busca com tal prática" ${ }^{366}$.

Também o art. 131 do Código Comercial de 1850 previa a necessidade de interpretação das cláusulas contratuais com base na intenção comum das partes (ou vontade objetiva), indicando que o comportamento das partes posterior à avença seria seu melhor indício ${ }^{367}{ }^{368}$.

Pois bem, se a função econômica dos diversos pactos parassociais patrimoniais foi apontada como a de integrar e modelar o regime jurídico do relacionamento societário existente entre os celebrantes, é preciso que os termos contratuais sejam avaliados com vistas a esse escopo, considerando os elementos essenciais da causa societária (como a colaboração, a participação nas contribuições, lucros e perdas) e os deveres dela decorrentes.

Ao contrário, a interpretação que tome suas cláusulas como as de meros contratos entre particulares e não como sócios, desconsiderando o todo a que servem (i.e. a relação societária entre os signatários) não condiz com a intenção comum que determinou a celebração do contrato e, nesse caso, reduziria o negócio à inutilidade ${ }^{369}$.

\footnotetext{
${ }^{366}$ Idem, pp. 222-223.

${ }^{367}$ Art. 131, 3. "o fato dos contraentes posterior ao contrato, que tiver relação com o objeto principal, será a melhor explicação da vontade que as partes tiveram no ato da celebração do mesmo contrato".

${ }^{368}$ De outro lado, o Código Civil de 2002, no art. 112 prevê que "nas declarações de vontade se atenderá mais à intenção nelas consubstanciada do que ao sentido literal da linguagem" sem prever critérios de apuração da vontade, razão pela qual segue necessário utilizar as regras previstas no Codigo Comercial, cuja "revogação formal pelo novo Código Civil (...) não logrou extirpá-las de nosso sistema jurídico. Assim como é impossível revogar as regras de Pothier (...) não se pode suprimir a penadas a tradição que existe nas entranhas de nosso direito mercantil" (PAUla A. Forgioni, idem, cit. p. 228).

369 Ainda com Paula A. Forgioni, "o contrato deve ser concebido de acordo com uma função (= função econômica = causa) e a interpretação da avença deve levar à sua consecução. Caso contrário, atirar-se-ia o contrato à inutilidade - decisão incompatível com a lógica do sistema. Em suma: se as partes contrataram, seu escopo era atingir determinada função econômia, porque o negócio não pode racionalmente ser entendido como atividade de deleite" (Teoria...cit., p. 223).
} 
O risco de interpretação inidônea também aparece, na espécie, quando se interpreta o pacto parassocial patrimonial "em tiras" ${ }^{370}$, ou seja, sem inserilo no panorama societário.

Nesse passo, convém lembrar a lição de Antonio Junqueira DE Azevedo, com escólio em Ortega y GASSEt, de que "o negócio jurídico é o negócio jurídico e suas circunstâncias" ${ }^{371}$.

Nos pactos parassociais patrimoniais, em que pese o conteúdo contratual versar sobre direitos patrimoniais dos sócios uti singuli ${ }^{372}$, a circunstância de entre eles haver relação societária impõe que sua interpretação a contemple ${ }^{373}$.

Tomando essa linha de argumentação, a chave de leitura dos pactos parassociais sob o prisma societário não se assenta, apenas, na produção de efeitos na sociedade de que podem ser privados os pactos em exame, mas na peculiaridade de voltarem-se ao liame entre os sócios.

$\mathrm{Na}$ mesma direção, a alínea 1 do art. 131 do Código Comercial de 1850 informava que "a inteligência simples e adequada, que for mais conforme a boa-fé, e ao verdadeiro espírito e natureza do contrato deverá sempre prevalecer à rigorosa e estrita significação das palavras".

Em contratos parassociais patrimoniais, essa regra assume singular importância na medida em que impõe o exame do verdadeiro espírito do

\footnotetext{
${ }^{370}$ Com a expressão rende-se homenagem ao Prof. ERos RoBerto GraU, incansável ao ensinar que não se interpreta direito em tiras ("[n]ão se interpretam textos de direito, isoladamente, mas sim o direito, no seu todo - marcado, na dicção de Ascarelli, pelas suas premissas implícitas. Ensaio e Discurso sobre a interpretaçãolaplicação do Direito. $3^{\mathrm{a}} \mathrm{Ed}$. Malheiros, São Paulo, 2005. p. 127). Da mesma forma, as disposições contratuais não podem ser avaliadas senão em seu conjunto.

${ }^{371}$ Negócio Jurídico, Existência, Validade e Eficácia, 4 ${ }^{\mathrm{a}}$ Ed., São Paulo, Saraiva, 2002, p. 118 .

${ }^{372}$ Como enfatiza OPPO ao se referir aos contratos em análise.

${ }^{373}$ FRANCISCO MARINO aponta, entre as circunstâncias a avaliar na interpretação contratual as "qualidades da parte ou das partes envolvidas (especialmente nos negócios intuitu personae) e eventual relação existente entre elas". Interpretação... cit., p. 116.
} 
contrato, em detrimento da literalidade das palavras e, para avaliá-lo, é necessário examinar não apenas a função econômica pretendida pelas partes, mas igualmente, o contexto global em que o negócio foi celebrado.

$\mathrm{Na}$ arena societária, os contratos parassociais patrimoniais só podem ter por espírito a disciplina de seus direitos de sócio até o ponto em que não desvirtuem a própria lógica societária, alicerçada nos pressupostos elementares do escopo comum e da partilha de resultados, positivos ou negativos, bem como sejam condizentes com os direitos e deveres gerados pela associação entre as partes, como o de lealdade e colaboração.

Contudo, o exame do "espírito do contrato" no contexto em que foi celebrado é dificultado, não raro, pela extrema sofisticação a que chegam algumas relações societárias, refletidas em um sem número de contratos, instrumentos, pactuações das mais diversas ${ }^{374}$.

Para interpretar adequadamente os contratos parassociais patrimoniais conforme seu espírito e assim determinar limites de sua validade, apreciar sua execução e os termos de seu adimplemento, ou mesmo verificar existência de fraude ou simulação que os fulmine, é imprescindível ter presente esse quadro complexo ${ }^{375}{ }_{-376}$, baseado, já se disse exaustivamente, em um relacionamento societário.

\footnotetext{
${ }^{374}$ Cf. as argutas considerações de Mauricio Moreira Mendonça de Menezes: "O jurista deve se voltar para analisar aspectos substanciais do fenômeno associativo, que muitas vezes não se limitam às cláusulas e condições formalmente convencionadas no contrato ou estatuto social, mas se encontram refletidas em diversos outros instrumentos, como acordos parassociais, correspondências, estudos de viabilidade rubricados pelos interessados e, ainda, em fatos concretos que, embora sejam relevantes, não chegaram a ser reduzidos a escrito, dado o dinamismo próprio da vida econômica" (Resolução de acordo de acionistas... cit., p. 158).

375 De fato, como ressalta LE CANNU a propósito da obra de DOM, "la complexité juridique a ses propres lois"(Les montages en droit des sociétés, cit., p. 7).

376 PAUla A. Forgioni comenta as conclusões de IAN MCNEIL sobre a complexidade dos negócios: "cada negócio está enraizado ("embedded") em relações complexas, de forma que se exige sejam considerados os elementos essenciais das relações que os envolvem" (Teoria.. cit. p. 213).
} 
Imbricam-se no contexto que norteará o intérprete, como se viu, caracteres peculiares como a colaboração das partes, a longa duração do relacionamento que os contratos parassociais patrimoniais têm por foco regrar e o caráter programático/normativo de suas estipulações.

\subsection{2 - Boa fé e tutela da confiança nas relações entre sócios. Estado de sócio e expectativas legítimas.}

a) boa-fé objetiva nas relações societárias

Voltando à primeira alínea do art.131 do Codigo Comercial, tem-se que a interpretação deve ser pautada pela boa-fé, sendo que o Código Civil de 2002 enunciou expressamente, no art. 113, que "[o]s negócios jurídicos devem ser interpretados conforme a boa-fé e os usos do lugar de sua celebração". Adicionalmente, prevê o art. 422 do Código Civil que "os contratantes devem guardar assim na conclusão dos contratos, como em sua execução, os princípios da probidade e boa-fé".

Como tem sido evidenciado na doutrina, as disposições acima transcritas relacionam-se com o império da boa-fé objetiva nos negócios jurídicos. Na lição já consagrada de Judith MARTINS-Costa a boa-fé objetiva consiste em modelo objetivo de conduta, fundado em probidade e lealdade com que o homem médio deve se comportar, adaptada ao contexto de cada caso concreto $^{377}$.

\footnotetext{
${ }^{377}$ Cumpre transcrever o entendimento da autora de que "por 'boa-fé objetiva' - segundo a conotação que adveio da interpretação conferida ao § 242 do Código Civil alemão, de larga força expansionista em outros ordenamentos, e, bem assim, daquela que lhe é atribuída nos países da common law - modelo de conduta social, arquétipo ou standard jurídico segundo o qual 'cada pessoa deve ajustar a própria conduta a esse arquétipo, obrando como obraria um homem reto: com honestidade, lealdade e probidade. Por esse modelo objetivo de conduta levam-se em consideração os fatores concretos do caso, tais como o status pessoal e cultural dos envolvidos, não se admitindo uma aplicação mecânica do standard, de tipo meramente subsuntivo" Da boa fé..., cit., p. 411, referindo-se a obras anteriores ("Os princípios informadores do contrato de compra e venda internacional na Convenção de Viena de 1980", in Revista de Informação Legislativa, n. 126, Brasília, abr-jun. 1995, p. 120 e "Crise e modificação da idéia de contrato no direito brasileiro, Revista do Direito do Consumidor, São Paulo, RT, 1992, v. 3, p. 141). Nos pactos parassociais, o fato de os celebrantes serem sócios deve ser fator a considerar no caso concreto, modelando a boa-fé segundo esse padrão.
} 
Esse modelo, segundo a autora, ostenta, no moderno direito contratual, um papel sistematizador ${ }^{378}$, que se traduz em fonte de deveres de conduta, prestação e proteção; em cânone de interpretação dos negócios jurídicos e em limite ao exercício de direitos subjetivos ${ }^{379}$.

Conforme acentua Menezes Cordeiro, a apreciação da boa-fé objetiva em cada caso concreto faz evidenciar aqueles que, no contexto, são os valores fundamentais do ordenamento jurídico, ultrapassando o exame de disposições individualmente consideradas ${ }^{380}{ }_{-}^{381}$.

Não se trata de cogitar, ao se referir ao predomínio da boa-fé objetiva em negócios empresariais, de solução "desconectada da realidade dos negócios e fundada em valores outros que não a busca do melhor funcionamento do mercado", mas, ao contrário, zelar para que a solução seja mais rente à realidade do caso concreto, propiciando mais confiança no sistema ${ }^{382}$.

\footnotetext{
378 Ainda com Judith MARTins-Costa, o perfil sistematizador da boa-fé "permite encontro de solução, pelo intérprete, que não está necessariamente tipificada nas categorias intrasistemáticas" (Os avatares do Abuso do Direito e o rumo indicado pela Boa-Fé, Trabalho apresentado ao Congresso Internacional de Direito Civil-Constituconal da Cidade do Rio de Janeiro - 21-23 de setembro de 2006, p. 33).

${ }^{379}$ Idem, p. 26.

380 “A boa fé exprime, em cada situação concreta, os valores fundamentais da ordem jurídica. Podemos considerar que, aos diversos problemas solucionados pelo Direito, não se aplicam, propriamente, normas isoladas: antes, todo o sistema é chamado a depor". (Manual..., cit., p. 185).

381 Anota Luis Gastão PAEs De BARros Leñes que a "exigência da boa-fé, porém, é mais acendrada nos chamadas contratos intuitu personae, onde a pessoa do contratante - não importa se pessoa física ou jurídica, passa a ser elemento causal do negócio, como nas chamadas sociedades anônimas de pessoas e nos pactos parassociais" (Resolução de acordo de acionistas por quebra de Affectio Societatis in AAVV, Temas de Direito Societário e Empresarial... cit. p. 447. Grifou-se)

382 Advertência é de PAUla A. FORGIONi em Interpretação de negócios empresariais no novo Código Civil Brasileiro in RDM, n. 130, p 27. A autora também esclarece, sobre a necessidade de exame da boa-fé em termos concretos, considerada a função econômica em jogo, que "[s]empre que o exercício da faculdade assegurada por cláusula desviar-se de seu fim econômico [i.e., de sua função econômica] haverá abuso de direito. Igualmente, o aviltamento à boa-fé, com a frustração da legítima expectativa considerada em termos objetivos, também será comportamento repelido pelo sistema de direito comercial, ainda com base nos arts. 187 e 422" (A evolução... cit., p. 134). Com relação aos pactos parassociais, também o direito societário, como ramo do direito comercial, depende da boa-fé objetiva e da proteção da legítima expectativa para sua higidez.
} 
A tutela da confiança, a propósito, demonstra-se, na expressão de Menezes Cordeiro, como um dos "princípios mediantes" da boa-fé, na medida em que ela oferece aos partícipes do negócio meio de defesa das legítimas expectativas que nele depositam, amparadas que são não pelo que explicitamente se coleta dos termos do negócio, mas por todas as normas que envolvem esse relacionamento contratual ${ }^{383}$.

Isto posto, é preciso considerar que nas relações entre sócios - alvo dos pactos parassociais patrimoniais, em exame - a boa-fé objetiva e a tutela da confiança estão ligadas de modo indissociável aos deveres de lealdade $e$ colaboração a elas inerentes ${ }^{384}{ }^{385}$, que serão tratados no ponto 4.5 , bem como ao estado de sócio de cada parte que, como já se apontou, é formado também pelas disposições dos pactos parassociais

Seguindo a advertência feita por COMPARATO, a interpretação que desconsidere a boa fé nas relações societárias, objetivada pelos critérios da

\footnotetext{
383 “A boa fé opera, por vezes, através de princípios mediantes. Destes, o mais significativo é o da tutela da confiança. Contracenando com a autonomia privada, a tutela da confiança opera em defesa das representações legítimas da continuidade que os diversos operadores jurídicos sempre colocam nas múltiplas ocorrências em que assentem a sua actividade. A sociedade é uma abstração. Apenas a confiança que os particulares tenham na sua consistência e na funcionalidade das normas que a rodeiam permite a operacionalidade do sistema" (Manual.., cit., p. 185)

${ }^{384} \mathrm{Na}$ síntese de Menezes CORDEIRo “como manifestação geral da boa-fé e da tutela da confiança, temos deveres de lealdade: entre sócios e entre estes e os administradores. A realidade societária exige que as pessoas possam confiar umas nas outras, pelo menos funcionalmente. Desse vector derivam várias aplicações, designadamente através das regras gerais do abuso do direito" (Manual.., cit., p. 186).

385 Ainda sobre a boa-fé nas relações societárias cf. LAURENT Godon, Les obligations des associés, Paris, Economica, 1999, p. 89 e ss. Vale reproduzir, em especial, seu entendimento de que "em definitivo, o princípio da boa-fé tem relevo considerável no direito de sociedades e se impõe tanto nas relações entre associados que perante a pessoa jurícia, seja perante a empresa em si entendida come um conjuntos de meios de trabalho e capital, impoondo o respeito do interesse dos salariados, dos credores, dos fornecedores, que do próprio Estado" "En définitive, le principe de bonne foi a une portée considérable en droit des sociétés et s'impose autant das les relations entre associés, qu'avec la personne morale, voire avec l'entreprise elle même entendue comme un ensemble de moyens en travail et en capital imposant le respect de l'intérêt des salariés, des créanciers, des fournisseurs, voire de l'Etat lui-même" (p. 90-91). Mais adiante na p. 91, explica ser um dever difuso, a ser observado em toda situação fática decorrente do fato de o relacionamento societário perdurar no tempo.
} 
lealdade e colaboração facilmente resulta em "absurdos lógicos e graves injustiças" ${ }^{386}$.

Ocorre que, muitas vezes, essa preocupação é dirigida apenas à interpretação do contrato de sociedade ou do estatuto social, ou ainda é referida no exame de deliberações assembleares.

Com base no que se expôs, cumpre frisar, assim, que também os pactos parassociais patrimoniais, porque instrumentos vitais para construção do relacionamento societário desejado pelas partes, devem ser examinados sob o enfoque da boa-fé entre sócios.

\section{b) Affectio societatis, confiança e expectativas legítimas}

Além do exame da boa-fé objetiva nas relações societárias, ao se interpretar um contrato parassocial patrimonial cabe ponderar que ele se demonstra necessário para dar concreção à intenção das partes ao associarem-se.

Em grande parte das sociedades anônimas fechadas, já se apontou, a figura de cada sócio (com sua reputação e específicas contribuições) prepondera sobre sua mera contribuição de capital. Ao buscar um sócio, ressaltou-se, as partes procuram o parceiro com que, juntos, perseguirão seus objetivos econômicos.

Nesse sentido, verifica-se entre os sócios um estado de ânimo continuativo que os leva a colaborar na busca pelos resultados almejados, resumido na expressão affectio societatis ${ }^{387}{ }^{388}$.

\footnotetext{
386 "Não resta dúvida de que essa característica de contrato de boa-fé varou os séculos e marca ainda, fundamentalmente, as nossas sociedades de pessoas, mesmo revestidas da forma acionária. O intérprete não pode, pois, deixar de levar em consideração esse princípio, sob pena de cometer, no summun ius formalista, absurdos lógicos ou graves injustiças" (Restrições à circulação de ações em companhia fechada: nova et vetera in Novos Ensaios.. cit., p. 40).
} 
Derivam desse estado legítimas expectativas sobre o comportamento de cada um dos sócios, com base naquilo que objetiva e concretamente se espera de alguém que se toma por sócio e, ainda, no contexto de cada específica sociedade, o que se espera de cada um dos sócios ${ }^{389}$.

Essas expectativas legítimas, objetivadas pelos deveres de sócio acima referidos; pela boa-fé que deve imperar nas relações societárias; e pelo escopo comum que determina a própria reunião das partes em sociedade, devem servir, também, como componente importante do processo interpretativo, tendo em vista que a affectio societatis que as gera enseja "uma exacerbação do cuidado e diligência próprios de um contrato bona fidei" ${ }^{390 \_391}$.

387 Fundamental, para o tema, o texto Restrições à circulação de ações em companhia fechada: nova et vetera de FABIO KONDER COMPARATO in Novos Ensaios e Pareceres de Direito Empresarial, Forense, Rio, 1981, pp.32-51. Cf. também, no direito francês, em que a noção de affectio societatis é muito utilizada na jurisprudência ALAIN VIANDIER, La Notion D'Associé, Paris, LGDJ, 1978, pp.75-91.

${ }^{388}$ A utilização "acrítica e abusada" da noção de affectio societatis é criticada no texto de Erasmo Valladẽo Azevedo Novaes França e Marcelo Vieira Von Adamek, "Affectio societatis": um conceito superado no moderno direito societário pelo conceito de fim social in Temas de Direito Societário, Falimentar e Teoria da Empresa, Malheiros, São Paulo, 2009, pp.27-68.

${ }^{389}$ Nas sociedades fechadas, a definição de papéis diversos dos sócios é traço comum. Pode haver o sócio investidor e o sócio "empresário", o sócio detentor da tecnologia e aquele com experiência comercial no mercado de atuação da companhia, entre outros. É mesmo intuitivo que, para a realização de atividade comercial, as partes procurem no outro as qualidades e potencialidades que, sozinhas, não ostentam.

$390 \mathrm{Na}$ opinião de Comparato: “A affectio societatis é, portanto, não um elemento exclusivo do contrato de sociedade, distinguindo-o dos demais contratos, mas um critério interpretativo dos deveres e responsabilidades dos sócios entre si, em vista do interesse comum. Quer isto significar que a sociedade não é a única relação jurídica marcada por esse estado de ânimo continuativo, mas que ele comanda, na sociedade, uma exacerbação do cuidado e diligência próprios de um contrato bona fidei. Em especial, o sócio que descumpre disposição estatutária e, sobretudo, contratual (pois a relação convencional é mais pessoal e concreta que a submissão a normas estatutárias) como é o caso de acordos de acionistas numa sociedade anônima, pratica falta particularmente grave sob o aspecto da ética societária; ele se põe em contradição com sua anterior estipulação ou declaração de vontade, revelando-se pessoa pouco confiável enquanto sócio (venire contra factum proprium)" (Restrições..., cit, p. 39. Grifou-se). Cf., ainda, AlAin Viandier, La notion..., cit., p. 79.

${ }^{391}$ Comentando a espécie dos acordos de acionistas, esclarece LEÃES que "seja qual for seu conteúdo (...), o acordo de acionistas é norteado sempre pelo interesse comum dos pactuantes. Nesses ajustes prevalece sempre a mesma exigência de duração do consenso e de comunhão de escopo que vigora nos contratos de sociedade. Ausentes essas condições, o acordo ficará igualmente comprometido, e, por consequência, se tornará suscetível de 
Nesse ponto e em conclusão, cumpre transcrever a lição de COMPARATO de que a affectio societatis é composta de dois elementos, a fidelidade e a confiança, que devem também orientar a intepretação dos pactos parassociais patrimoniais:

“[a] fidelidade é o escrupuloso respeito à palavra dada e ao entendimento recíproco que presidiu a constituição da sociedade, ainda que o quadro social se haja alterado, mesmo completamente. Por outro lado, a confiança é também um dever do sócio para com os demais, dever de tratá-los não como contrapartes, num contrato bilateral em que cada qual persegue interesses individuais, mas como colaboradores na realização de um interesse comum"

Assim, espera-se ter demonstrado, já de antemão, que qualquer iter hermenêutico que prescinda do exame dos elementos acima apontados no contexto global da associação societária entre os celebrantes afigura-se inidôneo aos pactos parassociais patrimoniais e à função econômica que desempenham.

\section{5 - Elementos de interpretação baseados em alguns princípios de sustentação à lógica societária}

Do que se expôs acima e desdobrando o exame dos critérios mais tradicionais de interpretação dos negócios jurídicos, parece ser útil e necessário, a seguir, apurar como alguns princípios que oferecem sustentação à própria lógica inerente a qualquer relacionamento societário podem ser utilizados na interpretação dos contratos parassociais patrimoniais pois, como salienta Trajano de Miranda Valverde,

"A ilicitude de um ato pode simplesmente decorrer da sua incompatibilidade com um sistema ou uma determinada instituição. Assim, em matéria de sociedade (...) não é exato dizer-se que tudo o que não é proibido, é permitido; cada instituição legal tem um mecanismo e uma função própria, e o que desnatura essa função e força esse mecanismo é ilegal" ${ }^{392}$

extinção" (Resolução de acordo de acionistas por quebra de Affectio Societatis in AAVV, Temas de Direito Societário e Empresarial... cit. p. 448).

392 Sociedades Anônimas, Rio, Borsoi, 1937, p. 332-333. 


\subsection{1 - Escopo comum: a base da noção de sociedade}

A noção de sociedade, no direito brasileiro, é dada pelo art. 981 do Código Civil: "celebram contrato de sociedade as pessoas que reciprocamente se obrigam a contribuir, com bens ou serviços, para o exercício de atividade econômica e a partilha, entre si, dos resultados".

Do enunciado se depreende que aqueles que celebram sociedade pretendem colaborar para atingir um escopo definido pelas partes ${ }^{393}$, cujos resultados serão compartilhados ${ }^{394}$. A reunião de esforços e recursos não é eventual, ocasional ou despropositada: ela atende a essa busca por frutos a partilhar ${ }^{395}$.

393 KARSTEN SCHMidT esclarece que se está em vista de um escopo comum, único, perfilhado pelas partes; não a comunhão, pelas partes, de vários escopos/finalidades individualmente perseguidos. Ou seja, um escopo comum supra-individual ("überindividueller Verbandszweck"). Cf. Gesellschaftsrecht, cit., p. 61. Opta-se, neste trabalho, por privilegiar a locução escopo comum em detrimento de fim social, na medida em que a primeira ressalta a união das partes para a consecução do objetivo, ainda que o mesmo não se possa fazer quando se estiver diante de sociedades unipessoais, o que não é o caso neste trabalho. A noção de escopo comum pode dividir-se no objeto social e no resultado final (lucro ou vantagem econômica), sendo o primeiro a atividade necessária para a obtenção do segundo. Para a interpretação do objeto social e as consequências de sua alteração e/ou desvio, cf. o clássico texto de José Alexandre TAVARES GuERrEiro, Sobre a interpretação do objeto social, in RDM 54, pp.67-72.

394 ARturo Dalmartello, em resumo, afima que "[1]a causa del contratto di società consisterebbe nell'intento comune della divisione dei guadagni, nella volontà d'unione, nella organizzazione collettiva delle forze patrimoniali singole (...), nella mira del raggiungimento d'un fine comune, o nella comunanza di scopo, etc. etc.. (I Contratti delle Imprese Commerciali, Padova, Cedam, 1958, p. 211).

395 Cumpre reproduzir o entendimento de Hermes Marcelo HuCK para quem “é conceito assente que a comunhão de escopo funciona como o elemento unificador de qualquer relação societária, seja qual for a forma jurídica através da qual se exteriorize. Se, num contrato qualquer, as partes posicionam-se dialeticamente frente a frente, já nas sociedades colocam-se lado a lado, voltadas para o fim comum. É esse desenho que define a própria filosofia informadora do conceito básico de sociedade. No caso específico das sociedades comerciais, o fim comum almejado, em torno do qual - e para qual - reúnem-se os sócios, é a produção de lucros. Há uma decisão conjunta de conjugação de esforços e trabalho, seguundo uma estrutura organicamente estruturada em busca desse objetivo" (Pactos Societários Leoninos, cit., p. 66. Grifou-se). 
Em todas as relações geradas a partir do contrato de sociedade, o escopo comum passa a "estrela polar" ${ }^{396}$ que orientará seu desenvolvimento. Na expressão de WiEDEMANn, o escopo comum acordado pelos sócios é a lei vital da sociedade ${ }^{397}$.

De modo especial - é preciso enfatizar - o escopo comum norteia as relações que se travam entre os sócios, levando à instauração - não apenas perante a sociedade, mas também entre eles - de deveres ${ }^{398}$. Segundo Auletta, a comunhão de escopo deve considerar-se constantemente presente na determinação e na interpretação das obrigações dos sócios, pois eles elegem, como fim essencial de sua relação, a sua consecução ${ }^{399}$.

${ }^{396}$ Expressão de WIEDEMANN, aplaudida por ERASMO VALLADÃo e MARCELO VON ADAMEK,
que reproduzem a lição do mestre alemão de que o fim social "além de ser elemento
constitutivo (...) também é dotado de eficácia funcional (funktionelle Wirkung), pois: (i)
fixa as diretrizes da política social; (ii) determina os direitos e deveres dos sócio (em
especial sua intensidade), delimitando, assim, as esferas individual e coletiva; e (iii) dirige
os estágios da vida social. Com efeito, as relações entre sócios e entre estes e a sociedade
é marcada pela finalidade comum" " “Affectio Societatis'...", cit. p. 45). 397 “der vereinbarte Zweck ist das Lebensgesetzt des Verbandes” (Geselschaftsrecht, cit, p. $10)$.

398 “A eficácia funcional da determinação do fim social revela-se (...) na medida em que impregna o conteúdo das relações jurídicas entre a corporação e os membros, e aquelas dos membros entre si" ("Die funktionelle Wirkung der Zweckabrede erweist sich (...) da $\beta$ sie die Rechtsverhältnisse zwischen verband und Mitglied und diejenigen zwischen den Mitgliedern untereinander inhaltlich prägt" HERBERT WIEDEMANN, idem, ibidem).

399 No original: "[1] a comunione dello scopo è da tenersi costantemente presente, nella determinazione e nella interpretazione degli obblighi dei soci; questi pongono come fine essenziale del loro accordo il raggiungimento di tale scopo" (Il Contratto di Società Commerciale. Requisiti - Conclusione - Vizi, Milano, Giuffrè, 1937, p.56). LAURENT Godon, comentando a disposição do Codigo Civil Francês que impôe que a sociedade seja constituída no interesse comum das partes, explica que essa redação "coloca em evidência a comunhão de interesses que liga os membros e que se opõe a que eles persigam seu interesse particular, egoísta, incompatível com o espírito societário. Por consequência, a consecução da exploração é precedida também da necessidade de um espírito de união naquilo que o decano Hamel enxergou como o primeiro elemento essencial do contrato de sociedade" (no original:"met en evidence la communauté d'intérêts qui li les membres et qui s'oppose à ce que certains poursuivent leur intérêt particulier, égoïste, incompatible avec l'esprit sociétaire. Par conséquence, la réussite de l'exploitation procède-t-elle aussi de la nécessité d'un esprit d'union dans lequel le Doyen Hamel voyait le premier élément essentiel du contrat de société”) Les obligations des associés, Paris, Economica, 1999, p. 86. Mais adiante, na mesma página, conclui que "para além das obrigações patrimoniais e objetivas, o contrato de sociedade exige o respeito de obrigações extrapatrimoniais e subjetivas que se qualificariam de "políticas", (no original: "au-delà d'engagements 
Em síntese, fica-se com a lição de J.X. Carvalho de Mendonça de que "os sócios cooperam para o escopo comum, e, em lugar dos interêsses antagônicos ou opostos, que se observam nos outros contratos, no de sociedade, todos os sócios se esforçam para o mesmo resultado, no qual estão empenhados 400 ,

\subsection{2 - Deveres dos sócios}

Da noção de sociedade depreende-se que o dever primordial de todo sócio é contribuir com recursos para que o escopo comum ou fim social seja realizado e, com isso, os resultados da atividade sejam atingidos e partilhados. Nada obriga o sócio, porém, a perseguir o escopo comum com todos os seus meios, renunciando integralmente à sua individualidade, a exemplo das comunidades de matiz socialista ${ }^{401}$, vedando-se, assim, prestações suplementares não previstas no estatuto social ${ }^{402}$.

Desse dever original, pecuniário, desdobram-se deveres laterais de conduta, gerados pela própria participação na sociedade, integrantes do estado de sócio ("Mitgliedschaftspflichten", na doutrina alemã) $)^{403}{ }^{404}$.

patrimoniaux et objectifs, le contrat de société exige le respect d'obligations extrapatrimoniales et subjectives que l'on qualifiera de politiques").

${ }^{400}$ Tratado de Direito Comercial Brasileiro, Vol. 3, 4 $4^{\mathrm{a}}$ ed., Rio de Janeiro, Livraria Editora Freitas Bastos, 1945, p. 14.

401 Wiedemann, Gesellschaftsrecht, p. 11, in verbis: "Die Mitglieder sind allerdings nirgends verpflichtet, den Gemeinschaftszweck mit allen Mitteln zu unterstützen und ihre Individualität aufzugeben: die Gesellschaft ist keine 'Lebensgemeinschaft'".

${ }^{402}$ Essa regra protetiva deve ser sopesada, em cada caso, com as reais necessidades da sociedade e com o que globalmente foi concordado entre os sócios.

403 Para KARSTen SCHMidT “a participação societária como relação jurídica enseja prerrogativas entre os sócios e a sociedade, mas também entre os próprios sócios. Essa dualidade de orientação de prerrogativas tem significado, sobretudo, para os deveres de lealdade e consideração, até a justificativa para deveres de ressarcimento de danos" (no original: "[d]ie Mitgliedschaft als Rechtverhältnis begründet eine Sonderrechtbeziehung zwischen dem Mitglied und dem Verband, aber auch unter den Mitgliedern selbst. Bedeutung hat diese mehrfache Richtung des Sonderrechtsverhältnisses vor allem für die Loyalitäts-und Rücksichtspflichten bis hinein in die Begründung von Schadenersatzpflichten".) Gesellschaftsrecht, cit., p. 552. No direito alemão é muito mais clara a relação entre acionistas, até pela seção específica da AktG (§53). Na mesma linha, 
Trata-se de deveres decorrentes do mandamento geral da boa-fé na execução do contrato de sociedade e da necessária confiança que deve haver entre os sócios ${ }^{405}{ }_{4}^{406}$, os quais devem ser observados para maior segurança nas relações societárias, ainda quando não haja disposições legais expressas que o determine.

São, portanto, "parte fundamental do direito societário 'não escrito' 407 ou, para adotar a terminologia de EROS Roberto GraU, do direito pressuposto. Instrumentalmente, são necessários à consecução do escopo comum e da manutenção da relação societária entre as partes.

aponta Menezes Cordeiro: "A lealdade exigível aos sócios inscreve-se no seu próprio status enquanto sócios. Tal status exprime uma série de direitos e de deveres, ínsitos na própria ideia de participação social. Entre os deveres em causa incluem se, precisamente, os da lealdade. Trata se de uma ideia antiga, depois retomada e aprofundada. Hoje, poderemos falar, neste domínio, no exercício das posições sociais de acordo com a boa fé, seguindo se as vias de concretização deste instituto: tutela da confiança (p. ex., proibição de venire contra factum proprium) e primazia da materialidade subjacente (p. ex., proibição de actos emulativos). (A lealdade no direito de sociedades. cit. p. 8.). Por fim, ANIBAL SANCHEZ considera que no lado passivo da posição jurídica do sócio "la única obligación propriamente dicha del sócio es la de realizar la aportación prometida. Con esta afirmación no se descarta, sin embargo, la posible relevancia ocasional de un discutido 'dever de fidelidad', derivado (...) de la aplicación específica del principio general de buena fe y del postulado de colaboración del sócio al 'interés común' que, por naturaleza, distingue al contrato de sociedad en todas sus manifestaciones" (Comentários... cit. pp. 99-100).

${ }^{404}$ Valendo-se de outra terminologia, DALMARTEllo ressalta a existência de obrigações do sócio fundadas na necessidade de sua colaboração para a consecução do escopo comum. ("[1]'obbligazione del socio, per chi voglia penetrarne il pieno contenuto, non comprende soltanto la prestazione patrimoniale e statica del conferimento, ma anche quella squisitamente personale e dinamica della collaborazione. I soci mettono insieme delle entità patrimoniali e s'impegnano di impiegarle, collaborando in una impresa. Scopo immediato del contratto di società è pertante l'obbligo di conferire e collaborare; scopo della collaborazione è il guadagno sociale e la sua ripartizione fra i singoli soci". I Contratti..., cit., p. 211).

405 Síntese fundada em HEINRICH LEHMANN, Gesellschaftsrecht, $3^{\mathrm{a}}$ Ed. atualizada por Rolf Dietz, Franz Vahlen, Berlin, 1970 ("Die Treuepflicht, die sich aus der engen Verbundenheit der Gesellschafter und dem Vertrauen ergibt, das sie sich entgegenbringenmüssen, um gemeinsam ein Handelsgewerbe zu betreiben, ist gegenüber der bürgerlich-rechtlichen Gesellschaften gesteigert”).

${ }^{406}$ Cf. Comparato, “Restrições...", cit., p. 40, mencionado na nota \#, acima.

407 Na expressão de KARSTEn SCHMIDT, "[d]ie Treuepflichten machen einen wesentlichen Teil der 'ungeschriebenen Legalordnung' im Gesellschaftsrecht". Gesellschaftsrecht, cit., p. 488 . 
Baseados no caráter fiduciário da relação societária, comumente são designados deveres fiduciários (fiduciary duties ${ }^{408}$ ) ou, no alemão, "Treuepflichten" (deveres de lealdade). Sua formulação teórica remonta ao século XIX, tendo sofrido avanços e retrocessos que marcaram o direito societário no decorrer do século XX, principalmente no direito alemão ${ }^{409}$.

Com base na doutrina alemã, mais avançada na matéria, pode-se apontar, sob a designação ampla de deveres de lealdade ("Treuepflichten"), o dever mais genérico de perseguir e fomentar o escopo comum, ("Zweckförderungspflicht"), o dever de lealdade propriamente dito (“Loyalitätspflicht”), o dever de consideração e respeito ${ }^{410}$; na doutrina italiana, enfatiza-se o dever de colaboração ${ }^{411}$.

${ }^{408}$ Cf. Menezes Cordeiro, A lealdade no direito de sociedades, in Revista da Ordem dos Advogados, dez/2006.

409 Para análise da evolução dos deveres de lealdade e sua configuração como dever de auxílio e consideração, cf. HERBERT WIEDEMANn, Vínculos de Lealdade e regra de substancialidade: uma comparação de sistemas, in AAVV, Temas de Direito Societário e Empresarial Contemporâneos... cit. pp. 147-168, onde há as principais referência bibliográficas no Direito Alemão. Ademais, para completa análise do desenvolvimento histórico dos "Treuepflichten" no direito alemão, cf. PETER STElzIG, Zur Treuepflicht des Aktionärs unter besonderer Berücksichtigung ihrer geschichtlichen Entwicklung, 2000. Cf. ainda, António Menezes Cordeiro, A lealdade no direito das sociedades in Revista da Ordem dos Advogados, Lisboa, dez/2006, (números de páginas não informados. Texto disponível em http://www.oa.pt/Conteudos/Artigos/detalhe_artigo.aspx ?idc=30777\&idsc=54103\&ida=541 29).

410 Essa escala é enunciada por KARSTEN SCHMIDT que, com relação ao direito alemão, indica serem os deveres de lealdade (Treuepflichten) os mais importantes deveres legais, comparando-se aos deveres de contribuição ao capital (Beitragspflichten), que entendem contratuais, ou seja, fundados na previsão do estatuto social a respeito. Com relação aos primeiros, esclarece o autor que levam por sua vez a deveres laterais. Todos os deveres seriam, assim, resultado e concretização do dever geral societário de fomento ao escopo comum (Zweckförderungspflicht). Gesellschaftsrecht, cit., p. 557. No Brasil, como se verá, os deveres de lealdade dos sócios entre si encontram fundamento no dever geral de boa-fé, inexistindo disposições específicas à exceção do caso do controlador, ao qual a lei 6.404/76 impõe expressamente deveres de lealdade e consideração para com os demais acionistas.

411 Também na doutrina brasileira é tradicional a referência ao dever de colaboração, como se pode depreender da passagem de J.X CARVAlho DE MEndonÇA: “os sócios devem manifestar a vontade de cooperar ativamente para o resultado que procurem obter, reunindo capitais e colocando-se na mesma situação de igualdade. É indispensável à sociedade a identidade de interêsses, a cooperação econômica, na frase de RIPERT, ou a vontade da colaboração ativa dos sócios, na expressão de THALLER, tendo êstes sempre em vista o 
O dever de lealdade dos sócios ${ }^{412}$, assim composto, dirige-se seja à sociedade, seja aos demais sócios ${ }^{413}$ e, na formulação de WiEdEmann, “compreende a orientação das relações jurídicas societárias para uma correta colaboração de todos os participantes a fim de atingir o fim social" 414

Nesse sentido, deve ser entendido como diretriz de conduta, como cláusula geral cujo preenchimento depende da análise de cada situação concreta em que seu cumprimento é exigido ${ }^{415}$. Ou seja, ainda com WiEDEMANN, “[o] conteúdo e a extensão dos deveres de lealdade regem-se de acordo com a respectiva projeção no agrupamento de interesses, devendo, portanto, ser determinados no caso concreto" ${ }^{416}{ }_{-}^{417}$.

fim comum, a realização de um enriquecimento pelo concurso dos seus capitais e da sua atividade. Muito bem explicava o nosso JOÃO MONTEIRO que "na colaboração está a idéia visceral de tôda a sociedade" Tratado, cit., vol.3, p. 23.

412 Também os administradores ostentam deveres de lealdade perante a companhia e os acionistas. Todavia, esse aspecto não será explorado por escapar ao tema da interpretação dos pactos parassociais patrimoniais.

413 Wiedemann explica, a respeito de a quem se destina o dever de lealdade, que "se colocam as relações jurídicas diretamente para com a sociedade como também para com os demais sócios, uma vez que a existência dessas relações é hoje incontroversa" Cf. Vínculos de lealdade..., cit., p. 153. Cf., ainda, KARSTEn SCHMidT, Gesellschaftsrecht, cit., p. 556, que separa os deveres dos sócios entre aqueles que geram pretensão para a sociedade (Sozialpflichten) e aqueles que geram pretensões individuais (Individualpflichten) e o célebre caso Linotype (BGH 1.02.1988) que consagrou entendimento na jurisprudência alemã de que os deveres de lealdade verificam-se entre acionistas - e não apenas perante a companhia.

${ }^{414}$ Lição pinçada por Erasmo Valladẽo Azevedo e Novaes França e Marcelo Vieira VON ADAMEK em “'Affectio Societatis'...", cit., p.46, nota 37. Grifou-se.

415 Confirma-no WiEDEMANN: "o dever de lealdade, no direito societário como um todo, apenas pode ser compreendido como uma cláusula geral, que põe um indicador de caminho para o comportamento correto na vida associativa, mas que recolhe, nas diversas relações jurídicas, distintos conteúdos”. Vínculos de lealdade... cit., p. 154. No mesmo sentido, KARSTEN SCHMIDT, "man mu $\beta$ sich darüber klar sein, das Loyalitätspflichten - und damit auch die gesellschaftlichen Treuepflichten - keine Rechtsquelle oder Rechtsnormen sind, sondern da $\beta$ von diesen Pflichten stets nur generalklauselhaft im Sinne konkretisierunsbedürftiger Pflichten aus einer Sonderverbindung (...) die Rede ist" (Gesellschaftsrecht, cit., p. 588).

${ }^{416}$ Vínculos de lealdade..., cit., p. 154.

${ }^{417}$ Para detalhado estudo do dever de lealdade em sociedades no contexto de joint ventures, cf. Matthias Baus, Treuepflichten des Aktionärs in Gemeinschaftsunternehmen, Frankfurt am Main, Peter Lang, 1991. 
Da mesma maneira, a intensidade dos deveres de lealdade depende mais da configuração da sociedade e dos relacionamentos societários que do tipo societário (formal) escolhido ${ }^{418}$, não cabendo, portanto, argumentar que eles existiriam apenas em sociedades de pessoas, muito embora tenham nelas se originado.

Importante notar, ainda, que os deveres de lealdade verificam-se não apenas durante a existência da sociedade, mas devem ser observados mesmo antes de sua constituição e depois de eventual desfazimento do vínculo do sócio, seja com relação à sociedade que frente aos demais sócios ${ }^{419}$.

O dever de colaboração dos sócios, nesse passo, demonstra-se como consequência necessária do escopo comum e da noção mesma de sociedade, vez que se não houvesse o comprometimento das partes em colaborar, a sua associação societária careceria de sentido. Mais que uma noção etérea de colaboração, os sócios encontram-se concretamente ligados ao dever de agir em prol de sua associação comum, devendo ser sancionadas condutas que, ao contrário, sejam inconciliáveis com esse dever ${ }^{420}$.

No mesmo sentido, o dever de consideração e respeito entre sócios ligase à confiança necessária ao desenvolvimento da relação societária, pois não é

\footnotetext{
418 KASTEN SCHMIDT, in verbis: "[a]ber ist doch jede Mitgliedschaft Quelle mehrseitiger Sonderrechtsbeziehungen. Wie dicht die Sonderrechtsbeziehung zum Verband und zu den anderen Mitgliedern im konkreten Fall ist, hängt dann weniger von der Rechtsform ab als von der tatsächlichen Gestaltung des Verbandes" (Gesellschaftsrecht, cit., p. 553. Grifouse).

${ }^{419}$ Cf. KARSTEN SCHMIDT, Gesellschaftsrecht, cit., p. 588.

${ }^{420}$ Auletta comenta que a vedação de concorrência dos sócios foi uma das manifestações do dever genérico de colaboração incluídos no Código Comercial italiano (Il Contrattto..., cit., p. 57). Com relação a esse aspecto e tendo em vista a causa do contrato de sociedade MARCELO VIEIRA VON ADAMEK afirma que "o sócio deve se abster de quaisquer comportamentos que, de alguma forma, possam obstar a sua eficaz persecução, e isso não se satisfaz apenas com uma atitute passiva, mas, em certos casos e dependendo da estrutura real pode exigir igualmente a colaboração ativa do sócio: não apenas uma abstenção, mas, por vezes, até mesmo uma ação" Abuso de minoria em direito societário (abuso das posições subjetivas minoritárias). Tese de Doutorado em Direito Comercial, Faculdade de Direito da Universidade de São Paulo, 2010, p. 140. Para estudo específico a respeito do dever de não concorrência do acionista no direito alemão, cf. Jörg SCHNEIDER, Wettbewerbsverbot für Aktionäre, Frankfurt am Main, Peter Lang, sd.
} 
concebível que os mesmos indivíduos que assumem o compromisso de colaborar para atingir determinado escopo comum comportem-se sem atentar para quaisquer impactos de seus atos para o relacionamento a que estão vinculados.

a) Deveres de sócio no direito positivo brasileiro

No direito brasileiro, os deveres de sócio encontram fundamento na regra geral de boa-fé objetiva, prevista nos art. 187 e 422 do Código Civil, não havendo seção específica, seja no Código Civil que na Lei de Sociedades Anônimas (lei 6.404/76), a respeito das relações entre os sócios em geral ${ }^{421}$.

A lei $6.404 / 76$, ao prever a figura do controlador como órgão da sociedade, dotado de poderes e responsabilidades, incluiu no parágrafo único do art. 116, que ele deve:

"usar poder com o fim de fazer a companhia realizar o seu
objeto e cumprir sua função social, e tem deveres e
responsabilidades para com os demais acionistas da empresa, os
que nela trabalham e para com a comunidade em que atua, cujos
direitos e interesses deve lealmente respeitar e atender" (grifou-
se).

Explicitou-se, aqui, o dever de lealdade do controlador para com os demais acionistas como consequência do binômio poder/responsabilidade de que é investido, em vista de sua maior capacidade de afetar a realização do escopo comum por todos partilhado e, assim, as eferas jurídicas alheias.

Contudo, em que pese não haver menção específica na lei, também os demais acionistas vinculam-se ao dever de lealdade na medida em que são sujeitos à regra geral de boa-fé e que são vedados comportamentos emulativos dos minoritários, ou mesmo o abuso de seu direito de voto (art. $\left.115^{422}\right)^{423}$.

\footnotetext{
${ }^{421} \mathrm{Na}$ Alemanha, a lei de sociedades anônimas (AktG) possui Capítulo sobre as relações entre sócio e sociedade, e dos sócios entre si ( 533 a a $\$ 75)$.

422 Art. 115. O acionista deve exercer o direito a voto no interesse da companhia; considerar-se-á abusivo o voto exercido com o fim de causar dano à companhia ou a outros
} 
4.5.3 - Escopo comum e deveres dos sócios como elementos para a interpretação de pactos parassociais patrimoniais

Voltando ao objetivo do presente capítulo, do que foi acima exposto pode-se colher valiosos elementos para a interpretação de pactos parassociais patrimoniais.

Consoante se procurou apontar, esses pactos têm por função econômica moldar a relação societária existente entre sócios gerando prerrogativas, deveres e direitos aos pactuantes, com base em direitos individuais e patrimoniais seus. Esse conjunto de regras integra a posição jurídica dos signatários naquela sociedade, ou, seja, seu estado de sócio.

Tomando os deveres de lealdade, verifica-se que eles operam para proteger os interesses não apenas da sociedade mas, no contexto em que foi firmado contrato parassocial patrimonial, também dos consócios que são parte desse contrato.

Evidencia-se, nesse ponto, e é preciso enfatizar, que no fenômeno societário em exame não é possível apartar duas figuras distintas: o sócio e a parte do contrato parassocial, já que a parte do pacto só o é porque é igualmente sócio, e o sócio tem seu conjunto de prerrogativas formatado, daquela maneira e naquela sociedade, porque é parte do pacto parassocial patrimonial.

Mostra-se inapelável, assim, a interpenetração de figuras, que permite que os deveres de lealdade do sócio devam ser considerados no exame de seu comportamento não apenas perante a sociedade ou os demais sócios no que se

\footnotetext{
acionistas, ou de obter, para si ou para outrem, vantagem a que não faz jus e de que resulte, ou possa resultar, prejuízo para a companhia ou para outros acionistas. (Redação dada pela Lei $n^{\circ} 10.303$, de 2001)

${ }^{423}$ Sobre o tema, cf. a tese de doutoramento de MARCElo Vieira von AdAmek, Abuso de minoria em Direito societário (Abuso das posições subjetivas minoritárias). FDUSP, 2010.
} 
refira a atos sociais como o voto, a administração e a fiscalização, mas antes de forma global, abrangendo sua conduta como parte do pacto parassocial.

Os deveres de lealdade, enquanto deveres de salvaguarda dos interesses dos demais acionistas pactuantes são invocados, então, para se apurar, em concreto, se determinada conduta do acionista é adequada à específica relação societária que criou com os demais, valendo-se dos pactos parassociais, bem como às legítimas expectativas criadas nesse relacionamento. Em outros termos, examina-se se a conduta é condizente com a função econômica do contrato celebrado e a boa-fé objetiva a ele correspondente, ou se, ao contrário, há ato ilícito previsto no art. 187 do Código Civil ${ }^{424}$.

No caso específico dos contratos parassociais com conteúdo patrimonial, ainda que essa percepção não seja imediata, como já se salientou nos capítulos anteriores, ela não é menos válida.

Ao contrário, é possível que justamente nos pactos de conteúdo patrimonial resida grande possibilidade de desvirtuamento da lógica societária.

Em muitos casos, o que à primeira vista pode parecer o exercício regular de direito previsto no pacto é, em verdade, ato ilícito. Essa constatação somente se faz possível se o intérprete não se limitar a aspectos formais da teoria geral dos contratos ou mesmo do direito de propriedade mas, ao contrário, perquirir os impactos da conduta naquela relação societária. Sim, pois se é pacífico, na atualidade, que no exame de toda e qualquer relação contratual deve-se considerar a boa-fé e lealdade de parte a parte ${ }^{425}$, isso é tanto mais verdade quando as partes são também sócias.

424 "Também comete ato ilícito o titular de um direito que, ao exercê-lo, excede manifestamente os limites impostos pelo seu fim econômico ou social, pela boa-fé ou pelos bons costumes".

${ }^{425}$ Cf. Antonio Junqueira de Azevedo, Novos Estudos... cit. p. 125. 
$\mathrm{Na}$ interpretação de pactos parassociais de conteúdo patrimonial, é crucial, assim, considerar que o dever de lealdade existente entre os sócios signatários deve servir de base para sua conduta, reprimindo comportamentos que sejam incompatíveis com o fim de sua associação comum.

Nesse passo, e tendo em vista a nem sempre imediata constatação do que ora se argumenta, vale transcrever, na íntegra, a bela e pioneira lição de COMPARAto que, ao examinar justamente o caso de pacto parassocial relativo a compra e venda de ações (patrimonial, portanto) asseverou precisamente que:

“[o]s poderes normalmente ligados à propriedade, como o de alienar, por exemplo, não podem ser exercidos segundo o mesmo critério, quando não há nenhuma relação societária envolvida nessa propriedade e quando, ao contrário, essa relação existe. A fortiori, a estipulação de preferência à aquisição de bens não pode ser interpretada da mesma forma, entre sócios e não-sócios. Se a relação societária existe e se, ademais dela, foi estipulado um direito de preempção de ações, está fora de cogitações o absolutismo da propriedade (vender a quem quiser, pelo preço que bem entender) e a máxima caveat emptor, pois não se cuida de interesses puramente individuais (mea res agitur). Trata-se, antes, de proteger e reforçar os laços de comunhão societária, dando-se aplicação ao princípio da fidelidade e da perseguição do interesse comum (nostra res agitur), que exclui toda manobra tendente a descartar o direito de preempção reconhecido aos sócios" (Grifouse).

É preciso ressaltar, por fim, que os deveres de lealdade acima sucintamente expostos não correspondem a qualquer forma de paternalismo, de proteção excessiva de partes menos "espertas", ou mesmo à supressão do erro ou da perspicácia de um ou outro acionista, com viés moralista; ao contrário, servem à tutela de relações societárias fundadas em confiança mútua de agentes econômicos que se reúnem em vista de um objetivo compartilhado, estabilizando-se comportamentos em vista de maior segurança e previsibilidade ${ }^{426}$.

\footnotetext{
426 Afinal, como salienta PAUla A. Forgioni, “[a] boa-fé no direito comercial não acompanha padrões que a apontariam como reflexo de altruísmo exacerbado ou de algo semelhante. Ao contrário, indica a retidão de comportamento no mercado, conforme os modelos ali esperados (inclusive o respeito às normas, próprio do homem ativo e probo).
} 
Se assim não fosse, e entre as partes de um relacionamento societário valesse a mais irrestrita liberdade de atuação, a própria ideia de sociedade restaria comprometida ${ }^{427}$.

\subsection{4 - Vedação ao pacto leonino}

Prosseguindo no exame de elementos fundamentais à lógica societária que devem impactar a interpretação dos pactos parassociais patrimoniais depara-se com a vedação do pacto leonino ${ }^{428}$.

A designação sociedade leonina advém de fábula segundo a qual uma vaca, uma cabra e uma ovelha colaboraram em uma caçada da qual também participou o leão e ele, ao final, ficou com todo o produto obtido ${ }^{429}$.

A ratio da proibição de pacto leonino estaria assentada, então, no fato de que seria um contrassenso admitir que agentes econômicos reunissem seus esforços para a consecução de um escopo comum sem que, ao final, os resultados (positivos ou não) fossem efetivamente repartidos.

Ou seja, se a sociedade é um relacionamento colaborativo, ele não o pode ser apenas com relação aos recursos e esforços empreendidos. Pois,

Ao se atrelar a um standard de comprotamento empiricamente observável, a boa-fé comercial abandona rasgos de subjetivismo para aflorar como linha determinável de conduta" (Teoria Geral..., cit., p. 101). Como se apontou acima, os deveres dos sócios permitem que se forme esse standard do que se tem por boa-fé nas relações societárias, ou seja, qual o padrão de comportamento esperado de um sócio.

${ }^{427}$ Não se pode perder de vista que em sociedade as partes compartilham objetivo comum e, assim, animam-se, na dicção de DALMARTEllo, por um espírito de solidariedade, no sentido de que a vantagem de uma deve ser também vantagem para a outra ("Si è osservato, infatti, che mentre nei contratti di scambio il contraente cura i propri interessi a detrimento e a scapito di quelli dell'altro (sein Schaden, mein Gewinn); (...) nel contratto di società gli interessi di tutti i contraenti andrebbero paralleli, sicchè l'intera relazione poggierebbe sullo spirito di solidarietà (sein Vorteil, mein Vorteil, mein Vorteil, sein Vorteil)" (I Contratti..., cit., p. 208).

${ }^{428}$ Para completo levantamento histórico e de direito comparado a respeito do tema, cf. Luis Vasconcelos Abreu, A sociedade leonina (art. 994. ${ }^{\circ}$ do Código Civil), in Revista da Ordem dos Advogados, $\mathrm{n}^{\circ}$ 56, II, agosto 1996, pp. 619-665. Vale também consultar o clássico de Angelo SRAfFA, Patto leonino e nullità del contratto sociale, Rivista del Diritto Commerciale, 1915, pp. 656-659.

${ }^{429}$ Cf. Luis Vasconcelos Abreu, A sociedade leonina, cit., p. 620. 
como ressalta PAUla A. Forgioni, as partes somente se vinculam por meio de contratos se, deles, esperam que resulte situação melhor que aquela verificada na sua ausência ${ }^{430}$.

Daí porque se diz que, em verdade, não há societas leonina já que a existência de pacto que prive as partes de lucros e/ou de perdas seria incompatível com a ideia de sociedade. Nesse sentido, anota KARSTEN SCHMidT que a caracterização de um tal relacionamento como societas somente poderia indicar ironia ou anedota por nele faltar o verdadeiro escopo comum, ficando um dos partícipes com todo o proveito da empreitada enquanto os demais apenas suportam os esforços ${ }^{431}$.

Analisando a evolução histórica da proibição do pacto leonino, bem como estudos de direito comparado na matéria, pode-se verificar que ela encontrou sua justificativa, por muito tempo e, sobretudo, nos direitos latinos, no fato de o lucro ter sido indicado nas legislações como elemento essencial do contrato de sociedade, enquanto na Alemanha outra linha de argumentação foi seguida, mais ligada ao escopo comum ${ }^{432}$.

Como consequência, encontra-se na doutrina posições que diferenciam o tratamento a ser dado conforme se trate de sociedade em que um dos sócios não participa dos lucros ou quando ele não participa das perdas. Como aponta LUis VASCONCElos ABREU, essa diversa concepção decorre, naturalmente, da própria conceituação de sociedade que cada ordenamento, em cada momento histórico, apresenta.

\footnotetext{
${ }^{430}$ Teoria Geral..., cit., p. 59.

431 Gesellschaftsrecht, cit. p. 58. No original: "Es liegt auf der Hand, wer hier den "Löwenanteil" erhält, und demgemä $\beta$ soll es am gemeinsamen Zweck fehlen. Da einer der Beteiligten allein die Vorteile ziehen soll, während alle anderen nur die Lasten tragen, heißt es, die Bezeichnung der Löwengesellschaft als 'societas' sei nur scherzhaft oder ironisch gemeint”. Retoma-se, aqui, a crítica de CompARATo, de que não se está, em verdade, perante uma sociedade.

${ }^{432}$ Conclusão que se extrai do exame feito por LuIS VASCONCElos Abreu, idem, pp. 623647.
} 
Nesse sentido, nos ordenamentos em que o escopo de lucro consta como elemento do contrato de sociedade, defende-se que a supressão de lucros a um sócio configuraria a sociedade leonina a condenar, ao passo que a nãoparticipação do sócio nas perdas não teria o mesmo efeito. Isso porque somente no primeiro caso a causa do contrato de sociedade seria atingida ${ }^{433}{ }_{-}^{434}$.

Com o desenvolvimento dos debates doutrinários, apurou-se que também o risco é elemento natural do contrato de sociedade, ainda que não expressamente previsto em $1 \mathrm{ei}^{435}$. Essa circunstância permite caracterizar como leonina a sociedade em que um dos sócios apenas ganha e nada arrisca ${ }^{436}$.

Nessa linha, é preciso enfatizar que o sócio deve se submeter à álea do negócio que procura desenvolver em conjunto e que o fato de as legislações preverem a responsabilidade limitada sobre as perdas não afasta esse risco, mas apenas restringe os efeitos das obrigações sociais ao patrimônio social, evitando sua comunicação com o do sócio.

433 O estudo de LUIS VASCONCElos ABREU apresenta completa resenha das posições doutrinárias no direito europeu, como as de SRAFFA, FERri, Graziani, Di SABATO, Ferrara Jr., Corsi, Piazza e Minervini, na Itália e Ferrer Correia, Pires de Lima, Antunes Varela e Pinto Furtado, em Portugal.

${ }^{434}$ Entre nós, cf. a posição de LEÃEs: "a participação de todos os sócios nos resultados da questão social é pressuposto indispensável à existência da sociedade. A participação dos sócios nos resultados da sociedade constitui um elemento essencial deste tipo contratual, de modo que, quando falta, teremos um contrato de outro tipo, mas não seguramente de sociedade. Já a participação de todos os sócios nas perdas não está impícita na noção de sociedade como elemento essencial". (Pactos Parassociais - Natureza Jurídica - Execução Específica - Opção de recompra de participação societária e inexistência de infringência dos arts. 288 do CComercial e 1.372 do CC, por não configurar pacto leonino, in $\mathrm{RT}-$ ano 74 - novembro de 1985 - volume 601, p. 47). O autor justifica a afirmação com o disposto nos arts. 287 do Código Comercial de 1850 e 1.363 do Código Civil de 1916, vigentes à época.

${ }^{435}$ A relação lucro/risco, curial no direito comercial, é assim sintetizada por CAIRU: "Não pode pretender lucro quem não concorrer para algum negócio com fundo industrial, ordem ou risco" (in PAUla A. Forgioni, Apontamentos sobre algumas regras..., cit. p. 39-40).

${ }^{436}$ Posição defendida entre nós, por Hermes MARCElo HuCK (Pactos societários leonino, cit., p. 67). THIBAUT MASSART apresenta interessante análise de posicionamento judicial que chancela operação de resgate de ações de acionista investidor em Cession d'actions. Promesse unilatérale d'achat. Prix Minimum. Caractère lèonin (non). Clause d'intérêt. Faculté de substitution. Note: Vive le capital-risque sans risque, in Bulletin Joly Sociétés, abril, 2002, pp.499- 509 . 
Como bem esclarece Hermes Marcelo Huck, ainda que o sócio não deva aportar mais recursos ou sacrificar seu patrimônio à sociedade para que ela faça frente às perdas derivadas da atividade social, ele continua sujeito ao resultado da empreitada, seja porque não houve lucro a distribuir, seja porque o próprio valor patrimonial de sua quota é afetado pelos resultados negativos da atividade ${ }^{437}$.

Outro aspecto debatido em doutrina é o fato de mais frequentemente a proibição de pacto leonino ser referida com relação a contratos sociais, o que levaria ao argumento de que pactos apartados não seriam sujeitos à restrição.

Estudos mais recentes, contudo, salientam a necessidade de avaliação material da proibição de pacto leonino incidindo sobre a relação societária, independentemente de, formalmente, não constar do contrato social. Ou seja, havendo vedação legal à sociedade leonina, deve ser condenado tudo o que, indiretamente, provocar o mesmo efeito, como já evidenciava COMPARATO ${ }^{438}$.

Por fim, os efeitos do pacto leonino são diversos nas variadas legislações, entendendo-se, para o bem da segurança jurídica, que o mais conveniente é decretar a nulidade apenas do pacto leonino, e não de toda a relação societária existente entre os signatários.

\section{a) Legislação brasileira}

A lei de sociedades anônimas prescreve, no art. 109, a participação nos lucros como direito essencial do acionista ${ }^{439}$, enquanto o Código Civil brasileiro apresenta a vedação de pacto leonino em seu artigo 1.008, in verbis:

Art. 1.008. É nula a estipulação contratual que exclua qualquer sócio de participar dos lucros e das perdas.

\footnotetext{
${ }^{437}$ Idem, ibidem.

${ }^{438}$ V. nota no Capítulo 2.

439 Sobre o tema, cf. o clássico de Luis Gastão Paes de Barros Leães, Do Direito do Acionista ao Dividendo, São Paulo, Obelisco, 1969.
} 
Anteriormente, o Código Civil de 1916 dispunha

Art. 1.372. É nula a cláusula, que atribua todos os lucros a um dos sócios, ou subtraia o quinhão social de algum deles à comparticipação nos prejuízos.

E, finalmente, o Código Comercial de 1850 previa:

Art. 288 - É nula a sociedade ou companhia em que se estipular que a totalidade dos lucros pertença a um só dos associados, ou em que algum seja excluído, e a que desonerar de toda a contribuição nas perdas as somas ou efeitos entrados por um ou mais sócios para o fundo social.

Ou seja, pelo Código Comercial decretava-se a nulidade da companhia ou sociedade, enquanto no Código Civil de 1916 a nulidade prevista era da cláusula contratual. Na opinião de LEÃEs, fundada em GraZIANI, essa peculiaridade da legislação comercial então vigente "repousa na ideia de que a comparticipação nos lucros e perdas diz respeito à própria causa da sociedade, atingindo assim o contrato em sua unidade".

Determinando expressamente a nulidade apenas da cláusula contratual, o Código Civil de 2002 alinhou-se com a necessidade de preservação das relações societárias e da própria sociedade enquanto pessoa distinta de seus sócios.

Um ponto importante é que no art. 1.008 mencionou-se genericamente a nulidade de "cláusula contratual", não fazendo referência direta a "contrato social", o que afasta dúvidas sobre a incidência da proibição a cláusulas contidas também em pactos parassociais.

\section{b) Pactos leoninos na prática societária}

Como se antecipou no Capítulo 2, a discussão sobre o caráter leonino de certos pactos parassociais de conteúdo patrimonial é verificada, principalmente, quando se examina os arranjos de compra e venda de ações estruturados para permitir via de saída aos sócios, em especial os ajustes 
fundados em opções de compra e de venda de ações que, como se disse, sempre mais são usados para a solução do vínculo societário entre as partes em virtude de inúmeras circunstâncias como desavenças, impasses, alterações de condições comerciais, entre outras.

Para parcela da doutrina e jurisprudência, esses pactos devem ser tidos por pactos leoninos quando as partes estipulam preço para a compra e venda de ações e/ou critério para determiná-lo sem considerar eventual desvalorização patrimonial sofrida pela sociedade.

Argumenta-se que o acionista vendedor é isentado da perda decorrente do risco da atividade empresarial, o que não seria compatível com a noção de sociedade e, por isso, alvo da proibição de pacto leonino ${ }^{440}$. Mais grave, sob essa ótica, são os casos sempre mais comuns em que se estipula que o valor a ser pago pelas ações deve equivaler ao valor investido acrescido de correção e juros.

De outro lado, os interessados na sobrevivência do ajuste argumentam que não pode haver restrição à livre fixação de preço de ações, visto que são bens particulares dos sócios signatários e "a proibição do pacto leonino aplica-se apenas nas relações da sociedade com seus associados e não naquelas dos associados entre si" ${ }^{441}$. Apontam, assim, que a circunstância de um acionista pactuar com outro o preço de sua participação em valor igual ao investido não se ligaria à noção de exclusão de participação das perdas necessária para configurar sociedade leonina.

A justificativa seria a diferença de causa entre o contrato de compra $e$ venda da participação acionária e o contrato de sociedade, esse sim sujeito à

\footnotetext{
${ }^{440}$ Posição externada por HUCK em Pactos societários leoninos, cit, p. 66 e pela Primeira Câmara Civil da Cour de Cassation francesa, conforme notícia de GuYon (Les sociétés..., cit. p. 320) e EMANuelle Claudel (Clauses léonines extra-estatutaires... cit., pp. 183189).

${ }^{441}$ Síntese de GuYon para o entendimento da Câmara Comercial da Cour de cassation (Les sociétés..., cit., p. 320).
} 
proibição de se prever que todos os lucros ou prejuízos da sociedade recaiam ou sejam subtraídos a determinado acionista ${ }^{442}$.

Essa visão é frontalmente oposta àquela que se procura desenvolver na presente tese, em que se enfatiza que a causa societária deve ser verificada não apenas no contrato de sociedade, mas em tudo o que os sócios pactuam em função e por conta do relacionamento societário entre eles existente. Ou seja, também os acordos de compra e venda de ações, conquanto relativos a bens de sua propriedade particular, estão inseridos no âmbito daquela relação societária ${ }^{443}$.

Finalmente, aponta-se a inexistência de dano a terceiros pelo ajuste entre as partes. Ou seja, ainda que a relação entre elas possa ser eventualmente descaracterizada pelo ajuste supostamente leonino, ele não afeta qualquer terceiro, mas apenas os pactuantes.

Cumpre esclarecer que, neste caso, a relação jurídica deveria ser tratada como verdadeiro mútuo, que não confere ao credor qualquer ingerência na vida da sociedade. Ao contrário, nos casos em discussão, o credor disfarçado de sócio - geralmente fundo de investimento - tem seu crédito garantido tanto pelas regras que convencionar para a compra e venda como também pela possibilidade de participar ativamente da sociedade (via acordos de voto, por exemplo), de modo a obter os resultados que entende satisfatórios para seu investimento ${ }^{444}$.

\footnotetext{
${ }^{442}$ Sobre a discussão relativa às diferentes causas envolvidas, cf. GABRiEllo PiAzzA, La causa mista credito-società, in Contratto e impresa, 1987, pp. 803-15).

${ }^{443}$ Retoma-se, nesse ponto, a insuperável lição de COMParato transcrita na página \#, supra.

${ }^{444}$ Vide, a respeito, MARIO Leite SAntos, Contratos parassociais e acodos de voto nas sociedades anónimas, Cosmos, Lisboa, 1996, pp. 75-77, em especial, nota 163.
} 
c) Vedação ao pacto leonino e interpretação dos pactos parassociais patrimoniais.

Das discussões acima referidas obtém-se a relevância do tema do pacto leonino nas relações societárias, o que exige do intérprete de contratos parassociais patrimoniais apurar, em cada caso concreto, se a ratio da proibição do pacto leonino está ou não sendo afetada pelas disposições contratuais.

Nesse exame, será necessário avaliar, ainda, até que ponto as disposições do pacto parassocial condizem com a proibição de pacto leonino ou se, ao contrário, apontam a relacionamento outro que não societário (ex. mútuo).

Em outras palavras, ao trazer a preocupação relativa a cláusulas leoninas para o processo interpretativo dos pactos parassociais patrimoniais contribui-se para evitar que eles sejam livremente usados para "fazer indiretamente aquilo que a lei diretamente proíbe" ${ }^{445}$, ferindo a lógica societária e a própria função econômica subjacente ao contrato de sociedade.

\subsection{5 - Direitos de sócio}

Outro elemento importante para que a interpretação dos pactos parassociais patrimoniais seja consentânea com sua função econômica de modelar o relacionamento societário existente entre as partes é o conjunto dos direitos de sócio previstos em lei e/ou no estatuto (ou seja, direitos de soci uti

\footnotetext{
445 Expressão de GUYON ("il ne servirait à rien d'edicter des règles d'ordre public (...) si les associés pouvaient faire indirectement, c'est-à-dire par des estipulations extrastatutaires, ce que la loir les interdit de faire directement, c'est-à-dire, dans les statuts Les sociétés..., cit., p. 307). Mais adiante o autor configura situação como essa como "teatro de aparências" (idem, ibidem). Sobre a fraude à lei, explica COPPER RoYER que a fraude a lei consiste "no fato de realizar um ato simulado e ostensivo, mas fictício, com o objetivo de eludir as disposições imperativas de um texto legal" ("La fraude à loi consiste donc dans le fait d'accomplir um acte simulé et ostensible, mais fictif, dans le but d'éluder les dispositions impératives d'un texte légal". Traité des Sociétés, Tome II - Principes Généraux et de leur application à la matière des sociétés, Paris, Sirey, 1939, p. 277).
} 
soci ${ }^{446}$ ), bem como construções doutrinárias e jurisprudenciais relativas àqueles direitos que não podem ser suprimidos aos sócios ${ }^{447}$.

Como se referiu anteriormente, os pactos parassociais patrimoniais referem-se a direitos dos sócios, que, em princípio, concernem apenas à esfera patrimonial dos signatários.

Contudo, no processo de sua interpretação é preciso perquirir se referidos ajustes parassociais atingem, indiretamente, direitos de sócio garantidos em lei ou no estatuto e que, por isso, ou são irrenunciáveis (no caso de direitos individuais $)^{448}{ }_{-44}$, ou somente podem ser modificados pela Assembléia Geral (no caso de direitos sociais estatutariamente previstos).

\footnotetext{
446 Os direitos sociais do sócio são divididos, na doutrina, entre direitos individuais, irrenunciáveis (na mesma linha de raciocínio dos direitos individuais do homem), e direitos sociais, cuja revogação somente pode ocorrer mediante aprovação assemblear. Sobre essa terminologia, esclarecem Egberto LACERda Teixeira e José AlexAndre TAVARES GUERREIRo que "os direitos dos acionistas perante a sociedade podem ser agrupados e duas grandes categorias: os direitos individuais e os direitos sociais. Distinguem-se uns e outros por dois aspectos fundamentais: (a) sua origem e (b) possibilidade de sua modificação. Assim os direitos individuais tem origem na lei, ao passo que os direitos sociais têm sua origem no estatuto. Os direitos individuais não são suscetíveis de modificação, nem pelos estatutos, nem pela Assembléia Geral; já os direitos sociais admitem modificação, por previsão estatutária, submetendo-se, portanto, ao princípio majoritário, que governa a vida da companhia desde sua constituição (Das Sociedades Anônimas..., cit., p. 278-279) No mesmo sentido, BRUnetTi (Trattato... , vol. I, p. 224).

${ }^{447}$ Conforme acentua Comparato, "o primeiro e mais claro limite ao exercício do poder, em qualquer tipo de sociedade, política ou privada, é dado pelos direitos fundamentais do sócio ou indivíduo. (...) É claro que, na sociedade mercantil, não se pode falar em direitos naturais dos sócios, anteriores à constituiçào social. Mas pode-se e deve-se frisar que, sem o respeito a certas prerrogativas pessoais elementares, não há sociedade, pura e simplesmente". Funções e disfunções do resgate acionário in RDM 73, p. 68).

448 A doutrina designa os direitos individuais dos sócios também como direitos próprios (Sonderrechte, no direito alemão) ou intangíveis. A lei 6.404/76 denomina-os direitos essenciais, elencando-os no ar. 109: direito de participar dos lucros sociais, direito de participar do acervo da companhia, em caso de liquidação, direito de fiscalizar, na forma prevista em lei, a gestão dos negócios sociais, o direito de preferência e o direito de retirada. O direito de voto, a seu turno, seria social, tendo em vista que o estatuto pode prever restrições a esse direito. Em clássico trabalho sobre o direito das minorias, WALDírio BULGARElli anota que "a construção dos chamados direitos essenciais dos acionistas decorreu da necessidade de se opor um limite ao poder quase absoluto das Assembléias, exercido pelas maiorias, entendendo-se que não obstante indispensável o princípio majoritário para a formação da vontade social, não poderia ir ao ponto de frustrar o 'status' do acionista. (A Proteção às Minorias nas Sociedades Anônimas, São Paulo, Pioneira, 1977, p. 28).
} 
Para avaliar essa proposição, serão comentados três direitos de sócio mais próximos aos temas previstos em pactos parassociais ${ }^{450}$ : o direito à livre circulação de ações, ou seja o direito não restar prisioneiro da sociedade; o direito de permanecer associado, ou seja, de não ser excluído do quadro social e o direito a manter a participação social não diluída ${ }^{451}$.

Tendo em vista as considerações tecidas no tópico anterior, não se explorará novamente, aqui, o direito essencial de participação nos resultados da atividade social.

a) direito a não restar prisioneiro da sociedade: circulação de ações $e$ direito de retirada

A preocupação de que o acionista não se torne "prisioneiro de seu título" é central no direito das sociedades anônimas. De fato, tomadas as

\footnotetext{
449 No dizer de Modesto CARvalhosa a respeito dos direitos individuais do sócio, "[v]isa a norma a tutelar o interesse público. Qualquer deliberação em contrário é nula, seja a simples decisão da assembléia, seja a modificação estatutária. Também será nula a convenção de renúncia ou disposição. E, mais, a ação de nulidade, em todas essas hipóteses, é imprescritível". Comentários à Lei de Sociedades Anônimas, 20 Vol., São Paulo, Saraiva, p. 338.

${ }^{450}$ Não se entende conveniente, nesta sede, esmiuçar totalmente o tema dos direitos de sócio, sua evolução legislativa e doutrinária ou mesmo seu tratamento jurisprudencial por fugir ao foco da argumentação. Por essa razao não se cuidará de direitos políticos dos sócios ou mesmo de todos os direitos previstos no art. 109 da lei 6.404/76.

${ }^{451}$ Esses três grupos mais abstratos reúnem diversas enunciações de direitos básicos dos acionistas, que são descritos de formas variadas nas legislações. No direito brasileiro, por exemplo, ao se referir ao direito de não ter sua participação diluída (abstrato), tem-se em concreto a previsão do direito de preferência na subscrição de aumentos de capital (concreto); ao direito de permanecer associado (abstrato) ligam-se as regras contra exclusão de sócio (nas limitadas) e a garantia de consulta a classe, no caso de resgate (concreto) e assim por diante. O que se procura fazer, aqui, é indicar alguns casos de direitos de sócio que, de forma geral, permitem a convivência na sociedade e tutela dos agentes, em linha com a lógica societária. Ademais, não existe uma lista, um rol completo de quais são os direitos essenciais e sociais dos acionistas ou uma sua clasificação definitiva, razão pela qual se entende mais produtivo tratar dos princípios que os embasam e as finalidades a que procuram atender. Sobre a variedade da classificação dos direitos dos acionistas, cf. Bulgarelli, A Proteção..., cit., pp. 30-31. O mesmo autor realça o fato de, no direito brasileiro, os direitos básicos previstos no art. 109 serem "acrescidos de outros que a lei contemplou, dispersos por todo o corpo do diploma legal, conferidos ora ao acionista individualmente, ora como integrante da comunidade, ora por sua posição como minoria (idem, p. 35). Na mesma linha, Modesto Carvalhosa, Comentários..., cit., pp. 338-339 e Menezes Cordeiro, Manual..., cit., p. 511.
} 
origens do tipo societário, a circulabilidade das ações foi apontada como um seu traço caracterizador, peculiar frente às sociedades de pessoas em que a alteração do quadro social dependia da concordância dos demais sócios, quando não resultava na dissolução total da sociedade.

Como bem explica Trajano de Miranda Valverde, contudo, "[a] transmissibilidade das ações e não sua livre transmissibilidade, é que constitui um dos característicos essenciais delas" ${ }^{452}$, sendo que "o princípio da limitação à transmissibilidade evoluiu na razão inversa do próprio conceito do que seja uma sociedade anônima" ${ }^{453}$, tendo em vista a presença expressiva de sociedades anônimas fechadas na generalidade dos ordenamentos jurídicos.

Como já se apontou no Capítulo 2, nas sociedades anônimas fechadas, ainda que não sejam previstas quaisquer restrições à circulação das ações a realidade dos fatos mostra que, em verdade, ela seria igualmente dificultada pela falta de liquidez. De outro lado, o caráter mais pessoal da relação entre os sócios acaba por exigir que certos limites à livre disposição das ações sejam previstos, o que pode ocorrer tanto no estatuto como em pactos parassociais.

Conjugando ambas as considerações, tem-se que a regra geral nas sociedades anônimas é a circulabilidade das ações, em contraposição ao que se verifica nas sociedades de pessoas. Todavia, reconhecendo-se que existem sociedades anônimas também ostentam traços dessas últimas, a legislação

\footnotetext{
452 Sociedade por Ações, cit., v.1, p. 209. Na lição de FABIO Konder ComparATO, “[e]mbora não conste no elenco dos direitos essenciais do acionista expresso no art. 109 da Lei $\mathrm{n}^{\circ}$ 6.404/76, ninguém põe em dúvida que a possibilidade de transferência das ações constitui uma dessas prerrogativas. Trata-se, com efeito, de um dos princípios fundamentais das sociedades acionárias. Mas a possibilidade de transferência, pelo acionista, das ações que possui, não implica, necessariamente, a completa liberdade de transferência. Quase todas as legislações admitem, expressamente, que os estatutos sociais contenham cláusulas restritivas da circulação das ações desde que, como é intuitivo, não acarretem a intransferibilidade prática da posição acionária" ( $O$ poder de controle..., cit., p. 179).

${ }^{453}$ Modesto Carvalhosa, Comentários..., cit., v. 1, p. 350.
} 
brasileira permite excepcionalmente, com relação a elas, que se erijam restrições estatutárias.

A redação do art. 36 da lei $6.404 / 76$ prevê que "[o] estatuto da companhia fechada pode impor limitações à circulação das ações nominativas, contanto que regule minuciosamente tais limitações e não impeça a negociação, nem sujeite o acionista ao arbítrio dos órgãos de administração da companhia ou da maioria dos acionistas"

Verifica-se, assim, a preocupação do legislador em, de um lado, atender à necessidade de controle dos acionistas sobre o quadro social e, de outro, evitar que essa autorização legal sirva de expediente para aprisionar o acionista na sociedade ${ }^{454}$.

Além disso, a necessidade de previsão de fórmulas para que o acionista vendedor receba contrapartida adequada é fundamental para que as cláusulas de restrição de circulação de ações possam se justificar, não traduzindo limitação indevida na liberdade do acionista ${ }^{455}$.

A interpretação dos pactos parassociais que prevejam cláusulas de restrição à circulação de ações ou mesmo pactos de compra e venda entre acionistas (como opções de compra e de venda, que também ditam regras para a alienação das ações) não pode desconsiderar essas preocupações.

Ainda que se argumente que o acionista pactuante pode renunciar à tutela legal, aceitando que as cláusulas sejam-lhe menos protetivas, não parece aceitável que o faça de forma absoluta, permitindo às partes

\footnotetext{
${ }^{454}$ A preocupação com o direito essencial do sócio em desfazer-se de suas ações verifica-se também para os casos de inclusão de restrição em momento posterior à constituição da sociedade, por decisão da maioria: "Parágrafo único. A limitação à circulação criada por alteração estatutária somente se aplicará às ações cujos titulares com ela expressamente concordarem, mediante pedido de averbação no livro de 'Registro de Ações Nominativas'”.

${ }^{455}$ Cf. Géraldine Goffaux-Callebaut, Du Contrat..., cit, p. 256-258, especialmente item 359. Para a autora, "[1]a détermination du prix des actions peut également poser des problèmes. L'exigence d'une juste contrepartie, d'un juste prix, corollaire de la libre cessibilité, est reconnue par la jurisprudence e la doctrine" (p. 258).
} 
beneficiárias da cláusula total controle sobre a venda de sua participação acionária ${ }^{456}$. Até porque, neste caso, ser-lhe-ia suprimido totalmente um dos atributos do próprio direito de propriedade das ações, que é o de delas dispor.

O que se comentou até aqui se refere aos casos em que o acionista deseja desfazer-se de sua participação acionária por meio da alienação de ações, ou seja, pela circulação de sua propriedade. Trata-se, assim, de intenção do acionista fundada apenas em sua conveniência pessoal de não mais fazer parte da sociedade.

Há situações, porém, em que a decisão do acionista de desvincular-se da sociedade é determinada por sua discordância de deliberações relevantes da Assembléia Geral, as quais, determinadas a critério de cada legislador, teriam o condão de alterar significativamente a base daquela sociedade e/ou as prerrogativas dos acionistas ${ }^{457}$.

Nessas hipóteses, em contraponto ao princípio majoritário, apresenta-se a resposta do direito de retirada ou recesso do acionista que discordar da deliberação ${ }^{458}$, direito essencial do acionista no direito brasileiro ${ }^{459}$.

\footnotetext{
${ }^{456}$ GÉRAldine GoffauX-Callebaut compartilha dessa preocupação: "il faut analyser les modalités de la clause ou du pacte pour voir si elles ne rendent pas l'actionnaire prisionnier de son titre en lui ôtant toute garantie" (idem, p. 257).

${ }^{457}$ No Brasil, o art. 137 da Lei $6.404 / 76$ prevê que "[a] aprovação das matérias previstas nos incisos I a VI e IX do art. 136 dá ao acionista dissidente o direito de retirar-se da companhia, mediante reembolso do valor das suas ações (art. 45), observadas as seguintes normas (...)". As matérias eleitas pelo legislador como autorizadoras do recesso são: I criação de ações preferenciais ou aumento de classe de ações preferenciais existentes, sem guardar proporção com as demais classes de ações preferenciais, salvo se já previstos ou autorizados pelo estatuto; II - alteração nas preferências, vantagens e condições de resgate ou amortização de uma ou mais classes de ações preferenciais, ou criação de nova classe mais favorecida; III - redução do dividendo obrigatório; IV - fusão da companhia, ou sua incorporação em outra; V - participação em grupo de sociedades (art. 265); VI - mudança do objeto da companhia; e IX - cisão da companhia. Todas essas matérias, justamente por sua relevância, enseja, a aprovação de acionistas que representam, no mínimo, a metade das ações com direito a voto, se maior quorum não for previsto no estatuto (art. 136).

${ }^{458}$ Cf. Luiz Eduardo Bulhões Pedreira:“[o] direito de retirada surgiu como contrapeso à competência, reconhecida à Assembléia Geral, de modificar as bases essenciais do contrato de companhia (...) imposta pela necessidade de a companhia se adaptar às modificações de seus ambientes. - com a faculdade do acionista de optar por não continnuar sócio de sociedade essencialmente daquela que existia ao subscrever suas ações" (Direitos dos Acionistas in Alfredo lamy Filho e José Luiz Bulhões Pedreira (coord), Direito das
} 
Considerando que as deliberações sociais devem ser sempre tomadas no interesse da companhia, é ela que, havendo discordância de acionista a respeito da deliberação, deve reembolsá-lo.

Tornando ao tema da interpretação dos pactos parassociais patrimoniais, se a lei proibe que o estatuto ou mesmo a Assembléia Geral retirem ao acionista seus direitos essenciais, naturalmente se conclui que os pactos parassociais patrimoniais não podem ter por efeito o mesmo resultado, visto que a lei, nesse passo, limitou sensivelmente a autonomia privada: o direito de retirada não pode ser renunciado em termos genéricos, no pacto parassocial ${ }^{460}$. Quando muito, poderá prever hipóteses específicas de renúncia ao exercício do direito previsto em lei.

Assim, por exemplo, cláusulas que obrigam o acionista a permanecer como sócio por determinado período de tempo (as "lock in clauses", mencionadas no Capítulo 2) não poderiam ter por efeito impedir cabalmente o acionista de exercer seu direito de retirada, nos casos legalmente contemplados.

Em outros termos, o acionista pode se obrigar a não alienar as suas ações, voluntariamente. Todavia, em presença de deliberação ensejadora de direito de recesso - que igualmente terá como resultado a sua retirada do quadro social - poderá exercitar regularmente seu direito, ainda que tenha subscrito pacto genérico de permanência por um determinado período de tempo, pois esse último não pode atingir seu direito essencial ao qual o acionista não pode renunciar, de antemão e de forma genérica.

Companhias, vol 1, Rio, Forense, 2009 p. 326). Para os contornos do direito de retirada e sua função de tutela dos acionistas - e não meio de enriquecimento - vale referir o excelente acórdão relatado pelo Ministro Eduardo Ribeiro (Resp 197.329 - São Paulo, $3^{\mathrm{a}}$ Câmara, julgado em 02.02.1999). Cf., ainda Otтo von Gierke, Sulla Storia del principio di maggioranza, Rivista delle società, 1958, pp. 1103-1120;

459 Art. 109. Nem o estatuto social nem a assembléia-geral poderão privar o acionista dos direitos de: (...) V - retirar-se da sociedade nos casos previstos nesta Lei.

${ }^{460}$ Carvalhos A, Comentários..., cit. p. 360. 
Com esse exemplo pode-se ponderar que se no processo interpretativo do pacto parassocial em questão o sistema de direito societário vigente no Brasil não for adequadamente compreendido, atendo-se - ao revés e ao modo dos hermeneutas da common law - ao texto contratual ${ }^{461}$, a mesma conclusão não será obtida.

\section{b) direito a permanecer associado}

\section{b.1) exclusão de sócio e pactos com opção de compra}

Ao lado do direito de o acionista desvincular-se da sociedade, seja por alienação de ações de sua propriedade, seja pela retirada ensejada por deliberações assembleares, outra garantia mostra-se fundamental para a sua segurança: o direito a permanecer associado, se assim o desejar ${ }^{462}$.

De fato, "o acionista é membro da sociedade, ele não pode ser privado desta qualidade porque se teria uma verdadeira expropriação. É somente com seu consentimento que seu direito pode desaparecer" ${ }^{463}$.

A exclusão de sócio, assim, é medida extrema e apenas excepcionalmente prevista nas legislações. No direito brasileiro, O Código Civil prevê a exclusão de sócio remisso (art. 1.004) e judicial, por justa causa (art. 1.030), na parte relativa às sociedades simples, bem como extrajudicial (art. 1.085), em caso de sociedades limitadas, nas quais a justa causa deve ser

\footnotetext{
${ }^{461}$ Cf. mencionado no item 1.3.2.

${ }^{462} \mathrm{Na}$ sempre hialina explanação de COMPARATo, “[n]inguém é obrigado a ser acionista nem a permanecer na companhia, mas, em contrapartida, ninguém pode ser privado, de modo indevido ou abusivo, de sua condição de acionista; porque, se o pudesse, todo o sitema de defesa dos direitos e garantias essenciais seria vão e absurdo" (Funções $e$ disfunções..., cit., p. 68). Constata-se com o autor, contudo, que "esse direito fundamental não é geralmente posto em foco pela doutrina" (idem, p. 73, nota 5).

${ }^{463}$ No original, “[1]' actionnaire est membre de la société; il ne peut pas être privé de cette qualité parce qu'il aurait là une véritable expropriation. C'est seulement avec son consentement que son droit peut disparaître" (GEORGES Ripert e G. ROBLOT, MICHEL Germain (atual.), Traité de Droit Commercial, cit., p. 376).
} 
apurada em Assembleia ou reunião de $\operatorname{sócios}^{464}$. A lei de sociedades anônimas prevê a hipótese de perda da qualidade de acionista em caso de acionista remisso ${ }^{465}$ e no caso de resgate de ações ${ }^{466}$.

No regramento das sociedades anônimas, assim, não há dispositivo específico e expresso autorizando a exclusão do acionista do quadro social em casos que escapem a aspectos patrimoniais, ou seja, que não digam diretamente com a obrigação fundamental do acionista de integralizar o capital social (ou com as especialíssimas operações de resgate).

E a justificativa pode ser encontrada no fato de que a lei, nesse ponto, não foi especificamente talhada para sociedades anônimas fechadas, em que outras obrigações do acionista são tão ou mais importantes que a contribuição ao capital e onde os laços de lealdade e de cooperação erigem-se com forte carga pessoal de um acionista para com os demais.

Nesse contexto, a exclusão de acionista mostra-se ainda mais excepcional, demandando a apreciação judicial de eventual pedido de exclusão do acionista que, muito embora tenha honrado a obrigação primária que lhe cabia pelo tipo societário, ou seja, a integralização do capital, comporta-se de

\footnotetext{
464 MARCELO VIEIRA VON ADAMEK apresenta síntese dos principais aspectos ligados às modalidades de exclusão de sócio previstos no Código Civil, destacando-se o exames dos juízos de proporcionalidade de igualdade de tratamento na exclusão por falta grave (Apontamentos à exclusão de sócios por falta grave no Código Civil, in AAVV, Temas de Direito Societário e Empresarial Contemporâneos - Liber Amicorum Prof. Dr. Erasmo Valladão Azevedo e Novaes França, São Paulo, Malheiros, 2011, pp. 185-215.

465 Art. 107. Verificada a mora do acionista, a companhia pode, à sua escolha: I - promover contra o acionista, e os que com ele forem solidariamente responsáveis (artigo 108), processo de execução para cobrar as importâncias devidas, servindo o boletim de subscrição e o aviso de chamada como título extrajudicial nos termos do Código de Processo Civil; ou II - mandar vender as ações em bolsa de valores, por conta e risco do acionista. (...). $\S 4^{\circ} \mathrm{Se}$ a companhia não conseguir, por qualquer dos meios previstos neste artigo, a integralização das ações, poderá declará-las caducas e fazer suas as entradas realizadas, integralizando-as com lucros ou reservas, exceto a legal; se não tiver lucros e reservas suficientes, terá o prazo de 1 (um) ano para colocar as ações caídas em comisso, findo o qual, não tendo sido encontrado comprador, a assembléia-geral deliberará sobre a redução do capital em importância correspondente.
}

${ }^{466} \mathrm{~V}$. apontamentos sobre o resgate de ações no item sucessivo. 
maneira desleal, falhando ao cumprimento dos deveres societários, impedindo o bom andamento dos negócios sociais e a consecução do escopo comum.

Para tanto, e diante da ausência de dispositivo legal expresso, os interessados na exclusão deverão comprovar judicialmente a impossibilidade de permanência do acionista por comprometimento do escopo comum, sendo certo que se trata de decisão radical a ser tomada pelo juiz, em vista do interesse da companhia na preservação da empresa e mediante pagamento de indenização $0^{467}$.

Por essas razões, nas sociedades anônimas fechadas os acionistas procuram alternativas extrajudiciais para o deslinde de desavenças, prevendo de antemão reprimendas contratuais para comportamentos que entendem desleais ou apenas indesejados entre eles.

Seguindo a prática societária norte-americana, essa alternativa cada vez mais é representada por opções de compra ("call options") outorgadas pelos acionistas uns aos outros, inclusive de maneira interligada.

\footnotetext{
${ }^{467}$ O tema da exclusão de acionista tem sido sempre mais explorado em sede doutrinária e jurisprudencial, em desdobramento da evolução das hipóteses de dissolução parcial da companhia, ou seja, encerramento do vínculo societário com um dos sócios. A dissolução parcial "propriamente dita" foi reconhecida como alternativa ao pedido de dissolução total de companhia, com o pagamento de haveres ao acionista que não mais encontrava condições de relacionar-se com os demais, com risco à atividade social. Desenvolveu-se, então, o argumento de que, em condições semelhantes, o acionista poderia requerer não a sua própria retirada da sociedade, mas a expulsão daquele que, por sua conduta, inviabilizava o prosseguimento da sociedade. Sobre o assunto, confira-se o excelente artigo de PRISCILA MARIA PEREIRA CORRÊA DA FONSECA, em que são referidos e comentados os principais acórdãos que sustentam o argumento. Em particular, vale transcrever a precisa síntese fornecida pela autora com relação ao amparo legal da exclusão de acionista no direito positivo brasileiro, com base no art. 1.030 do Código Civil: "Malgrado a previsão de exclusão judicial esteja inserida no capítulo referente às sociedades simples, aplica-se, indiscutivelmente, tal modalidade de expulsão às sociedades limitadas como também às sociedades anônimas fechadas. É que diante da manifesta lacuna da Lei das S.A. - que apenas prevê expressamente a exclusão o caso de acionista remisso (art. 106 e 107, inciso II) e de resgate de ações (art. 44) - mas principalmente em razão da natureza intuitus personae da sociedade anônima fechada, admite-se, sem restrições, a aplicação subsidiária daquelas regras atinentes às sociedades de pessoas" (A dissolução parcial inversa nas sociedades anônimas fechadas in Revista da AASP, $\mathrm{n}^{\circ}$ 96, Mar-2008. p. 110). V. também, MARio Engler Pinto JR., Exclusão de Acionista, cit., e, comentando a acolhida jurisprudencial da preservação da empresa pela exclusão de sócios, PAULA A. Forgioni, A Evolução do Direito Comercial... cit., pp. 94-98
} 
Em alguns pactos, inclui-se dentre os eventos deflagradores de seu exercício as circunstâncias similares às que ensejariam, nas sociedades limitadas, a exclusão de sócio por justa causa; em outros, a opção de compra é outorgada sem a previsão de eventos condicionantes de seu exercício, bastando a manifestação de vontade do beneficiário, no modo e tempo previstos ${ }^{468}$.

No primeiro caso, apesar da aparente celeridade e simplicidade, como se apontou no capitulo 3, a execução específica da opção de compra poderá encontrar entraves, pois sempre poderá haver discussão a respeito da real verificação do evento autorizador, na tentativa da parte a ser "excluída" de defender-se.

Mesmo em se tratando de opção de compra incondicionada, ou seja, cujo exercício independe da verificação de eventos especificados no contrato, a discussão poderá recair sobre o momento do exercício da opção ou mesmo sobre o preço a ser pago ao acionista que deverá retirar-se da sociedade ${ }^{469}$.

A interpretação do ajuste deverá considerar, então, se a opção de compra contratada como sucedâneo da exclusão de sócio garantirá

\footnotetext{
${ }^{468}$ Referência é feita, novamente, ao comentário de PAUL LE CANNU à decisão judicial em que se examina se a execução dessas cláusulas comporta exclusão de acionistas. (Validation de la clause buy or sell..., cit.) Os juízes da Corte de Apelação concluem que, tratando-se de cláusula de saída concordada entre as partes, ela não teria o caráter de sanção ("[p]our la Cour d'appel, l'exclusion est par elle-même une sanction. En revanche, la clause de sortie acceptée ne revêt pas cette nature" p. 171).

${ }^{469}$ O tema é tratado em Agravo de Instrumento (TJSP, AI n. 0458561-06.2010.8.26.000, 1a. Câmara de Direito Privado, rel. Des. Carlos Augusto de Santi Ribeiro, 12.04.11) cujas principais considerações convém transcrever: "[a]duz o agravado que em 24 de agosto de 2007 foi excluído da sociedade quando premente a valorização das ações da Flow CCTVM em razão da abertura do capital da BM\&F. Isto se deu quando o interessado teria comprado a sua participação nas empresas, valendo-se de um 'instrumento de opção de compra' de depositando o valor correspondente a apenas 7\% do capital social" (...) "Vale ponderar, todavia, que somente após ampla produção de provas é que se poderá aferir, mediane juízo declarativo de certeza, se a supracitada 'opção de compra' de ações é válida ou não (o agravado alega que foi uma 'manobra' para exclui-lo dos quadros da empresa sem observância aos arts. 1.004 , § único e 1.085 do Código Civil), se o autor tem direito de continuar a ser sócio da corré e qual o quinhão que ele efetivamente possui (...), bem como a alegada circunstância do recorrente ter desconsiderado a valorização das ações quando do exercício da opção de compra" (grifou-se).
} 
efetivamente ao excluído a não-expropriação de suas ações, seja pela real verificação dos eventos previstos como deflagradores do exercício; seja pelo pagamento de valor justo ${ }^{470}$.

O argumento contrário a essa última preocupação - e que poderia ser levantado em interpretação do pacto parassocial patrimonial feita exclusivamente sob a ótica da teoria geral dos contratos - seria o de que o preço deve ser livremente pactuado entre as partes sem maiores considerações societárias, tendo em vista que será um ou mais acionistas quem comprará as ações do acionista "excluído" - e não a companhia. Ou seja, que qualquer relação com os critérios legais de apuração de haveres e/ou de cálculo de valor de reembolso ou de resgate seria descabido.

Essa posição não parece plenamente satisfatória pois, inexistindo previsão legal nas sociedades anônimas para exclusão de acionista, não seria aceitável simplesmente transpor contratualmente o instituto de um tipo societário a outro, sem fazê-lo acompanhar das garantias legalmente previstas para o acionista alvo da exclusão, travestindo-o de mera compra e venda.

A preocupação com a indenização justa do excluído deve ser observada, igualmente, nos casos de exclusão contratualmente estruturada, para que realmente se apresente como contrapartida à limitação de seu direito de permanecer associado, em prol da companhia e não dos acionistas que exercerão a opção.

Também será preciso avaliar se opções de compra previstas em pactos parassociais patrimoniais não conferem aos acionistas que poderão exercê-la a possibilidade de retirar arbitrariamente do acionista seu estado de sócio, em circunstâncias não contratadas, ainda que com pagamento do valor justo. Isso

\footnotetext{
${ }^{470}$ A apuração do valor real da ação com base em todos os elementos do ativo é necessária na dissolução total da companhia. Se a exclusão é permitida como alternativa à dissolução total, o mesmo critério deveria ser obedecido. Cf TJSP, Apel. Civ. n ${ }^{\circ}$ 217.352-1/7, 8 Câmara Cível do TJSP, rel. Des. José Osório, j. 03.05.1995, referido por PRISCILA CORRÊA DA FONSECA (idem, p. 113).
} 
porque é direito fundamental do sócio permanecer associado, salvo se não tiver expressamente manifestado desejo diverso.

Pelo exposto quer parecer que a opção de compra não será abusiva, sob a ótica societária, assim, se realmente for exercida naqueles quadrantes dentro dos quais o acionista outorgante concordou em abrir mão de seu estado de sócio e se corresponder a pagamento de valor justo.

Por essa razão, para que de fato haja celeridade na execução do contrato, sem prejuízo da tutela do direito do acionista em permanecer associado, é fundamental que os termos contratuais da opção de compra sejam muito bem descritos, prevendo-se tempo, modo e eventos autorizadores de seu exercício, os quais devem ser formulados de maneira mais objetiva possível, acompanhados de critérios de apuração do valor real da ação, mínimo aceitável para a fixação do preço ${ }^{471}$.

Caso contrário, havendo definições genéricas para as circunstâncias em que um acionista está obrigado a vender suas ações para os demais, a margem para desvios e abusos é naturalmente maior, demandando reflexão mais profunda e amplo conjunto probatório, no momento de sua interpretação e execução.

\section{b.2) resgate de ações}

Ainda que não ligado diretamente ao tema da interpretação dos pactos parassociais patrimoniais, entende-se conveniente referir outra modalidade prevista na lei de sociedades anônimas para que o acionista seja privado de seu estado de sócio: o resgate de ações, definido como a operação pela qual a

\footnotetext{
${ }^{471}$ Fala-se em mínimo pois os ajustes geralmente prevêm cálculos fundados em múltiplos do valor real da ação ou mesmo definem, entre si, o que entendem por valor real e como ele deve ser calculado. Cf. a respeito, Luis GASTÃo PAES DE BARROS LEÃEs, A definição de Ebitda, Selic e Gaap, in Pareceres, vol. II, São Paulo, Singular, 2004, p. 1159-1172.
} 
companhia paga ao acionista para retirar de circulação as ações de sua propriedade ${ }^{472}-473$.

Caso o acionista seja titular de ações cujo resgate é desde logo previsto no estatuto social — ou seja, ações resgatáveis - essa perda da qualidade de sócio não só é conhecida e tem seus termos definidos estautariamente (valor de reembolso, prazo de resgate, entre outros) como o acionista expressamente com ela anuiu ao subscrever as ações. Não há que se falar, pois, em lesão a seu direito de permanecer associado ${ }^{474}$.

Quando o resgate é decidido em assembléia, ele poderá atingir uma classe inteira de ações ou ações determinadas por sorteio ${ }^{475}$. No primeiro caso,

\footnotetext{
${ }^{472}$ Art. 44. O estatuto ou a assembléia-geral extraordinária pode autorizar a aplicação de lucros ou reservas no resgate ou na amortização de ações, determinando as condições e o modo de proceder-se à operação. $\S 1^{\circ}$ O resgate consiste no pagamento do valor das ações para retirá-las definitivamente de circulação, com redução ou não do capital social, mantido o mesmo capital, será atribuído, quando for o caso, novo valor nominal às ações remanescentes.
}

${ }^{473}$ Competa análise do instituto, com resenha das principais manifestações doutrinárias é feita por LUIS LORIA FLACKS, Aspectos societários do resgate de ações in RDM 123, pp. 120-142, 2001, com referências ao então projeto de lei que culminou na lei 10.303/2001.

${ }^{474}$ Muito embora as ações resgatáveis (e/ou preferenciais com privilégios de reembolso) mostrem-se mecanismos de grande valia para a estruturação de companhias e acomodação dos interesses de diversos grupos de acionistas que a ela acorrem, sua aceitação não foi pacífica, sobretudo na Europa. Como exemplo dos ricos debates travados sobre o assunto, vale conferir os volumes publicados em Giurisprudenza commerciale, em 1979 e 1980 ("Azioni privilegiate e partecipazione alle perdite"), reunindo pareceres de GiOvANNI Caselli, Arturo Dalmartello, Agostino Gambino e Pier Giusto Jaeger. A respeito de sua utilização como instrumento legítimo para levar a efeito a participação do acionista financiador e na mesma linha do que foi exposto a respeito dos pactos leoninos, LiNo GUGLIELMUCCI aponta que a participação do financiador assemelha-se mais a um financiamento que a uma participação acioniária ("La partecipazione della finanziaria appare, dunque, assai più simile a un finanziamento, che non a una partecipazione vera e propria. Quali sono, allora, le differenze fra questa sorta di operazione atipica di finanziamento e una ordinaria operazione di finanziamento?) mas, entretanto, são conferidos a esse financiador direitos de sócio com "maggiori possibilità operative e maggiore credibilità" (Lo smobilizzo delle partecipazioni nei patti parasociali delle finanziarie regionali private, in Rivista delle società, 1980, pp. 1196-201).

475 Art. $44(\ldots) \S 4^{\circ} \mathrm{O}$ resgate e a amortização que não abrangerem a totalidade das ações de uma mesma classe serão feitos mediante sorteio; sorteadas ações custodiadas nos termos do artigo 41, a instituição financeira especificará, mediante rateio, as resgatadas ou amortizadas, se outra forma não estiver prevista no contrato de custódia. 
e salvo previsão diversa no estatuto, será necessária a concordância de titulares de, pelo menos, cinqüenta por cento das ações da classe atingida ${ }^{476}$.

Essa exigência foi introduzida na reforma da lei de sociedades anônimas pela lei 10.303/2001, em resposta à então frequente utilização do resgate como instrumento de exclusão de acionista ${ }^{477}$, amparada pelo entendimento de que seria um direito potestativo da companhia, ao qual o acionista "excluído" não poderia se insurgir ${ }^{478}$.

Cabe notar que se trata de uma fórmula de saída da sociedade, prevista em lei, cuja conclusão, contudo, depende da existência de lucros ou reservas da companhia. É a companhia e não seus acionistas que se obrigam com o titular das ações resgatáveis a honrar o contratado.

No que toca ao critério de definição do preço de resgate deliberado em Assembléia (não estatutário, portanto), há discussão doutrinária relativa a seu alinhamento com os critérios para emissão de ações em aumento, valor contábil das ações ou, como parece mais justo sob o argumento da contraposição ao direito do acionista em permanecer associado, o valor real das ações, tal como referido ao se comentar as opções de compra, acima ${ }^{479}$.

\footnotetext{
${ }^{476}$ Art. $44(\ldots) \S 6^{\text {o }}$ Salvo disposição em contrário do estatuto social, o resgate de ações de uma ou mais classes só será efetuado se, em assembléia especial convocada para deliberar essa matéria específica, for aprovado por acionistas que representem, no mínimo, a metade das ações da(s) classe(s) atingida(s).(Incluído pela Lei $n^{\circ} 10.303$, de 2001)

477 FÁbio Konder Comparato comenta a redação original do art. 44 da Lei 6.404/76 criticando o abuso do instituto, pois "o excessivo e condenável liberalismo da lei brasileira permitiu que o negócio de resgate servisse, distorcidamente, para beneficiar o acionista em detrimento da companhia, ou o acionista controlador em detrimento do acionista". (Funções e disfunções do resgate acionário, in RDM, 73, p. 69).

478 Cf. RESP n. 68.378-5-PR, relator Min. EDUARdo Ribeiro, comentado por PAUlO DE Lorenzo Messina e Paula Andrea Forgioni, Sociedade por Ações..., cit., p. 417.

479 LUIS LORIA FLACKS comenta as diversas opiniões doutrinárias de MoDESTO CARvalhosa e TAdeu de Chiara (critério alinhado ao art. 170), José Luiz Bulhões PEDREIRA (contra), FABIO KONDER COMPARATO (valor real, partindo do valor contábil e incluindo todos os elementos do ativo) OSMAR BRINA CORREA LIMA (critérios de reembolso), Trajano de Miranda Valverde, Wilson Campos Batalha e Pontes de Miranda (valor real corrente em bolsa ou, não havendo, o valor nominal da ação). (Aspectos..., cit. pp. 135-137).
} 


\section{c) direito a não ter sua participação diluída injustificadamente}

Outro direito essencial do acionista é o de manter sua participação societária, ou seja, não vê-la compulsoriamente diluída, com prejuízo a seu quinhão das reservas e acervo social, bem como à sua possível ingerência na administração da sociedade ${ }^{480}$.

No direito brasileiro, o direito de preferência ${ }^{481}$ na subscrição de ações e outros títulos conversíveis em ações consta do rol do art. 109. Para efetiva tutela do acionista, porém, não basta prever o direito de preferência na subscrição de ações, se o efetivo exercício desse direito puder ser obstado.

Assim, o art. 170, $\S 1^{\circ}$ prevê que o preço de emissão de novas ações deverá ser fixado sem a diluição injustificada dos antigos acionistas, elencando critérios que, respeitados, resultam em operação aceitável, ainda que comporte diluição dos acionistas que não exercitarem seu direito de opção $\mathrm{O}^{482}$.

Como de resto ocorre com os direitos essenciais, os pactos parassociais patrimoniais não podem servir de meio para que o direito à não-diluição seja

\footnotetext{
480 "C'est la traduction légale du droit qui appartient à l'actionnaire sur l'actif social; l'emission d'actions nouvelles viendrait diminuer la quitité de son droit. Le droit préférentiel de souscription est um droit individuel de l'actionnaire" (RIPERT e. ROBLOT, Michel Germain (atual.), Traité de Droit Commercial, cit., p. 621).

${ }^{481}$ Mauro Rodrigues Penteado, amparado em Pontes de Miranda, esclarece ser o termo preferência equivocado, tendo em vista que, na espécie, não se trata de dotar o acionista de direito preferencial frente a outros que com ele concorrem para o mesmo objetivo; o termo opção seria, assim, tecnicamente correto, pois se refere ao poder do acionista de subscrever ou não o aumento proposto, a seu critério (Aumentos de capital nas sociedades anônimas, São Paulo, Saraiva, 1988, p. 194).

${ }^{482}$ Art. $170, \S 1^{\circ}-$ O preço de emissão deverá ser fixado, sem diluição injustificada da participação dos antigos acionistas, ainda que tenham direito de preferência para subscrevê-las, tendo em vista, alternativa ou conjuntamente: I - a perspectiva de rentabilidade da companhia; II - o valor do patrimônio líquido da ação; (Incluído pela Lei $\underline{n}^{\circ}$ 9.457, de 1997); III - a cotação de suas ações em Bolsa de Valores ou no mercado de balcão organizado, admitido ágio ou deságio em função das condições do mercado.
} 
elidido ou mesmo implicar renúncia irrestrita e prévia por parte dos signatários a essa garantia legal ${ }^{483}$.

Exemplo desse risco pode ser colhido em pactos que, não raro, prevêm o financiamento da sociedade pelo controlador, garantindo-lhe a possibilidade de, a seu critério e a qualquer tempo, fazer aprovar aumento de capital com emissão de novas ações, cuja integralização se dá com o crédito existente contra a sociedade.

Essa deliberação, conquanto benéfica à sociedade - que não será obrigada utilizar seus recursos para pagar os empréstimos - não é inócua quanto aos demais acionistas e as disposições contratuais que eventualmente a prevejam deverão ser interpretadas com vistas a essa circunstância.

Para que o ajuste seja válido, o mesmo pacto parassocial deveria prever renúncia expressa e específica dos acionistas com relação ao aumento de capital em questão (ou à série de operações de mesma motivação), determinando as condições em que ele será realizado e o valor do preço de emissão a ser aplicado. Em suma: quais as condições em que o acionista efeticamente concorda em ver sua participação diluída.

Mais uma vez, no caso apresentado, a interpretação do pacto não pode deixar de considerar essas preocupações de natureza societária, observando o ajuste apenas pela ótica do direito contratual.

\section{d) Conclusão}

Do que acima se expôs, nota-se que os direitos essenciais do acionista são importante baliza a considerar na interpretação dos pactos parassociais patrimoniais.

É preciso avaliar, pois, se o contrato em análise oferece risco de elisão desses direitos essenciais, em afronta ao mandamento legal constante do caput

${ }^{483}$ Em respeito, assim, ao mandamento do caput e do Parágrafo $2^{\circ}$ do art. 109. 
e do parágrafo 2 do art. 109. Ademais, ainda que haja previsão de renúncia do acionista, ela somente pode ser feita e intepretada de modo restrito, atingindo casos específicos em que o direito essencial em jogo possa ser exercido (e não o será), e não como renúncia genérica, abstrata e “à largada" de toda possibilidade de seu exercício.

Afinal, o que se procura garantir ao se prever os direitos essenciais ao acionista é a possibilidade exercê-los, se assim lhe aprouver; sua renúncia pode atingir, pois o exercício do direito, e não o direito em si.

\section{6 - Outros elementos apontados na doutrina.}

4.6.1. Introdução: Pactos parassociais patrimoniais e a discussão sobre autonomia contratual no direito societário.

Nos itens anteriores, procurou-se apontar elementos para a interpretação dos contratos parassociais patrimoniais em vista de sua função econômica, focada no regramento e estruturação da relação societária entre as partes. A proposta partiu, assim, do exame de regras consagradas de interpretação de negócios jurídicos (item 4.4), chegando, no específico, à análise de aspectos fundamentais à relação societária, que não podem ser descurados na interpretação dos pactos parassociais patrimoniais (item 4.5).

$\mathrm{Na}$ doutrina, contudo, as preocupações que animaram o estudo ora realizado são tradicionalmente tratadas no âmbito de tema mais vasto, qual seja, o dos limites da autonomia contratual no direito societário, que, no Brasil, como se adiantou no Prólogo, não tem sido explorado de maneira consistente.

No debate doutrinário sobre o tema ${ }^{484}$, assim, os pactos parassociais são mais frequentemente examinados pelo viés dos limites da autonomia das partes

\footnotetext{
${ }^{484}$ No direito alemão, fala-se em Gestaltungsfreiheit im Gesellschaftsrecht (liberdade de configuração no direito societário); na França, em liberté contractuelle en droit des sociétés e, na Itália, autonomia privata nel diritto societario.
} 
em celebrá-los e definir seus conteúdos. Em que pese essa diversa perspectiva, julga-se relevante referir os principais limites apontados, avaliando se também constituem elementos a ponderar na interpretação dos contratos parassociais patrimoniais ${ }^{485}$.

Em linhas gerais, pode-se apontar, na doutrina, três principais limitações à autonomia contratual em vista dos pactos parassociais ligadas ao respeito ao tipo societário; ao interesse social e à ordem pública societária ${ }^{486}$.

\subsection{2 - O respeito ao tipo societário}

O império do princípio da tipicidade societária representa, para as partes, a primeira limitação da autonomia contratual no direito societário. Assim, não lhes é dado celebrar sociedade que fuja aos tipos expressamente previstos em lei ou mesmo modificar todas as regras aplicáveis à forma de sociedade adotada ${ }^{487}$, em nome da segurança jurídica. Sob outro prisma, a limitação da autonomia é justificada, ainda, pelos efeitos e privilégios que, em contrapartida a lei faz derivar de cada tipo societário e o sistema que se erige

\footnotetext{
485 Nessa linha, LAURENT CONVERT refere-se à ordem pública, a cláusulas imperativas do estatuto e o interesse social, com amparo em aresto da Corte de Cassação ("Une convention qui n'est contraire ni à l'ordre public, ni aux clauses impératives des statuts ou à l'intérêt social doit a contrario être en principe autorisée. Cass. com, 13 févr. 1996 revue des sociétés 1996, p. 781, note J.J Daigre”. L’imperatif... cit. p. 499, nota 55).

486 KLAUS HOPT esclarece que a jurisprudência de cada ordenamento indica caminhos diversos para a definição das regras cogentes que impactariam a autonomia contratual. Assim, na França e Espanha, especial relevo recebem os "princípios gerais de direito societário"; na Itália, a descrição e respeito ao tipo contratual; na Alemanha, a instrumentalização dos deveres de lealdade ("Treuepflichten") ou o respeito à boa-fé ("Treu und Glauben"), bem como na Holanda e na Suíça outras cláusulas gerais sao examinadas no direito societário (Gestaltungsfreiheit in Europa, cit., p. 130). No campo específico dos pactos parassociais, GUYON anota, no mesmo sentido de ConverT (nota anterior) que "de manière génerale, on doit admettre que les conventions entre associés sont valables lorsqu'elles ne sont pas contraires à une règle d'ordre public, à une stipulation impérative des statuts ou à l'intérêt social” (Les sociétés, cit., p. 309).

${ }^{487}$ Comparando a tipicidade societária e aquela contratual, GUYON esclarece que “n'existe que des sociétés nommées et non des sociétés innommés ou 'sui generis'. D'autre part les associés n'ont pas la faculté de modifier toutes les règles applicables à la forme de société qu'ils ont adoptée". Sobre o tema, no direito brasileiro, fundamental a consulta à obra de Rachel Sztajn, Contrato de sociedade e Formas Societárias, São Paulo, Saraiva, 1989.
} 
em torno deles para sustentá-los, bastando referir a responsabilidade limitada ou ilimitada do sócio e a sua relação com a proteção de credores e terceiros.

O próprio surgimento dos pactos parassociais e sua proliferação, como se mencionou nos capítulos iniciais, podem ser compreendidos como decorrência do primado da tipicidade, pois esses ajustes podem ser caracterizados como tentativas das partes em conformar seu relacionamento societário de forma mais personalizada frente ao que a lei prevê para o tipo societário em questão: geralmente concentrando-se em aspectos de organização e funcionamento da sociedade, que deverão ser refletidos no estatuto social.

Com essa premissa, mostra-se natural a preocupação de que os pactos parassociais não constituam subterfúrgios das partes para burlar as regras cogentes sobre a caracterização do tipo societário ${ }^{488}$.

A principal dificuldade encontrada é, porém, identificar quais seriam, na legislação de cada ordenamento, os traços que realmente caracterizam o tipo societário e que, portanto, não podem ser corrompidos pelas partes pela celebração de pactos parassociais ${ }^{489}$.

Em que pese essa ponderação, tendo em vista que os pactos parassociais patrimoniais não se referem a aspectos de organização e funcionamento da sociedade anônima, o critério de validade do pacto fundado no respeito ao tipo

\footnotetext{
${ }^{488}$ Como salientou Hopt (nota acima), sobretudo na Itália, esse critério de apuração de validade dos pactos é muito comentado.

${ }^{489}$ Sobre a diferenciação do métodolo tipólógico e a diferenciação entre tipo e conceito, cf. Giorgio De Nova, Nuovi Contratti, Torino, UTET, pp.10-16 ("Il metodo tipologico. Em especial, com relação à dificuldade ora apontada, anota o autor, com base em Larenz, que "[m]entre il concetto si elabora mettendo in evidenza gli elementi comuni a tutti gli individui del gruppo, ed è quindi una somma di elementi caratteristici tutti necessari, il tipo si elabora individuando i dati caratteristici in funzione di un quadro complessivo che si coglie mediante una intuizione globale: sicché non è necessario che tutti i dati siano presenti in tutti gli individui del gruppo. Ne consegue che mentre sussumere significa rispondeere in termini drastici (sì o no) alla domanda se il caso individuale rientri nel concetto, cioè ne presenti tutti gli elementi essenziali, il quesito se il caso di specie sia riconducibile al tipo consente invece una risposta graduale (più o meno), che è in funzione della corrispondenza con il quadro generale" (p. 12).
} 
societário não parece, em princípio e abstratamente, contribuir como elemento a ser considerado em seu processo interpretativo.

\section{6 .3 - o respeito ao interesse social}

Outro critério de validade dos pactos parassociais apontado em doutrina é o respeito ao interesse social: seriam válidos pactos parassociais que não lhe servissem de afronta.

Novamente, aqui, o critério parece à primeira vista mais relevante ao exame de pactos parassociais políticos ou organizativos, em vista dos quais há possibilidade mais próxima de atuação das partes em desrespeito ao interesse social. O reconhecimento desse fato pode ser verificado, no direito brasileiro, do parágrafo $2^{\circ}$ do artigo 118 da lei de sociedades anônimas, que veda ao signatário do acordo de acionistas invocá-lo para se eximir de suas responsabilidades no exercício do direito de voto e/ou do poder de controle ${ }^{490}$. Ou seja, ainda que haja acordo de voto e de exercício conjunto de poder de controle, o acionista deve sempre orientar-se pelo interesse social, independentemente do que foi pactuado.

Um exame mais aprofundado da questão, porém, denota o impacto do interesse social também sobre os pactos parassociais patrimoniais, mesmo que se refiram, apenas, à esfera patrimonial dos signatários: essa contratação, como se afirmou anteriormente, insere-se no âmbito de um relacionamento societário, em que as partes devem atuar em vista de um escopo comum.

$\mathrm{Na}$ medida em que o interesse social é consequência do escopo comum $^{491}$, e esse último, como se viu, é a estrela polar dos relacionamentos

\footnotetext{
$490 \S 2^{\circ}$ Esses acordos não poderão ser invocados para eximir o acionista de responsabilidade no exercício do direito de voto (artigo 115) ou do poder de controle (artigos 116 e 117).

${ }^{491}$ Não cabe, aqui, referir toda discussão a respeito da noção de interesse social, dividido o debate entre a corrente contratualista que o enxerga como interesse comum dos sócios e aquela institucionalista, que, ao revés, identifica-o com o interesse da companhia, do ente que se desprega da pessoa dos sócios. Entende-se, pois, que o fundamental, independente
} 
societários, também na interpretação dos pactos parassociais de cunho patrimonial sua eventual violação deverá ser avaliada, espécie com relação àqueles ajustes que, muito embora se refiram a direitos patrimoniais dos sócios, geram efeitos na sociedade, como, por exemplo, as prestações acessórias.

Não se trata, contudo, de anular a separação patrimonial entre acionista e sociedade, exigindo que o acionista sacrifique sua esfera patrimonial em benefício do interesse social ou de admitir que todo negócio jurídico celebrado pelo acionista sofra ingerência de terceiro, ou seja, da companhia.

O que se mostra necessário, porém, é examinar cada pacto parassocial sob a premissa de que as partes signatárias são também acionistas, sócias, e por isso devem respeitar deveres de lealdade, dentre eles, como se explicou no item 4.5, o dever de atuar em prol do escopo comum, fundamento último do interesse social ${ }^{492}{ }_{-}^{493}$.

da posição adotada, é apresentar o interesse social como consequência lógica da ideia de escopo comum. Não há sociedade sem escopo comum, então o interesse social pode ser extraído do interesse à boa consecução desse escopo. Cf. a respeito, as considerações de Sophie SCHILler, Les limites..., cit., p. 120 e seguintes. A autora conclui que, como índice de restrição à autonomia contratual "[1]'intérêt social est une notion polysémique qui peut correspondre à l'intérêt des associés ou à celui de l'entreprise (...) Il est alors difficile d'envisager d'utiliser la notion d'intérêt social" (Idem, p. 129). No mesmo sentido, cf. Cristina Ceroni, Simulazione... p. 1125.

${ }^{492}$ Para interessante e completa análise a respeito da correlação entre interesse social e dever de lealdade, confira-se a tese de doutoramento de MARCELO VIEIRA VON ADAMEK, Abuso de minoria em direito societário (abuso das posições subjetivas minoritárias), em especial pp. 137-142 e 146-150. No estudo, o autor aponta, com propriedade, a maior utilidade da noção de dever de lealdade frente àquela de interesse social para o tema do abuso de minoria. Dessa análise, pode-se dizer que também no campo da interpretação dos pactos parassociais patrimoniais o critério do respeito a deveres de lealdade por parte dos signatários parece ser mais eficiente que o exame do respeito ao interesse social.

493 Cf. Géraldine Goffaux-Callebaut "le droit des sociétés comporte des principes généraux non écrits, garanties destinées à protéger l'associé, tels que le droit de vote, le droit d'être associé ou, dans le cadre des sociétés anonymes, la libre négotiabilité des actions. Il contient également en germe l'idée d'un intérêt social qui doit guider le fonctionnement de la société qui constitue le cadre des conventions em cause" (Du contrat en droit... cit. p. 240 . Grifou-se). 


\title{
4.6.4 - O respeito à ordem pública societária
}

Grande parte das referências doutrinárias, especialmente francesas, a respeito dos limites da autonomia contratual na redação de pactos parassociais indica serem eles determinados pela necessidade de respeito à ordem pública societária ${ }^{494}{ }^{495}$, que seria formada pelas regras imperativas e princípios do direito societário ${ }^{496}$.

Como evidenciam Yves Guyon e Sophie Schiller, contudo, verificar concretamente o conteúdo da noção de ordem pública societária para apurar sua eventual violação é tarefa árdua, trazendo insegurança para quem a ela se volta $^{497}{ }_{-498}$.

\begin{abstract}
${ }^{494}$ Seguem algumas manifestações da doutrina francesa nesse sentido: Yves GuYON ("[1]e rappel du principe de la liberté des conventions et l'absence d'une interdiction de contracter entre les assocés ne suffisent pas, car il faut aussi tenir compte de l'ordre public sociétaire (...) les limites de cet ordre public sont floues" Les Sociétés..., cit., p. 308); GÉRALdine GoffauX-Calebaut ("En tant que contrats, ils devront répondre aux exigences du droit commum des obligations, mas il faut également tenir compte de leur place particuliére. Conclus le plus souvent dans le cadre des sociétés anonymes, ces pactes ne devront pas contrevenir à l'ordre public sociétaire, composé de principes généraux et de règles légales particuliéres. Pour reconnaître leur validité, il faut mettre em oeuvre ce balancement entre la liberté contractuelle el l'ordre public sociétaire. (...) La nature de ces pactes et le contexte particulier expliquent la diversité des sources de l'ordre public. De façon générale, la jurisprudence a pris en considération ces deux élements et a posé des conditions générales de validité qui empruntent au droit des contrats et aux principes du droit des sociétés. De façon plus spécifique, l’ordre public se traduit également par un ensemble de règles législatives plus précises qui, tantôt restreignent la validité de ces conventions, tantôt confirment la liberté des associés de les conclure. (Du Contrat ..., cit., p. 239, grifou-se)

${ }^{495}$ Em Portugal, Ana Felipa Leal vai na mesma linha ao afirmar que "[c]aso seja possível, dentro dos limites da interpretação, retirar a aplicabilidade da norma societária a outros contratos, então aí subsumir-se-á o acordo parassocial ao regime das normas imperativas societárias, o que implicará a sua invalidade no caso de o seu conteúdo ser contrário a estas" (Algumas notas sobre a parassocialidade... cit. p. 158).
\end{abstract}

496 Tendo por objetivo, segundo GUYON, “a proteção dos acionistas minoritários, a igualdade dos acionistas e a proteção dos credores", o que demanda o recurso a noções imprecisas como o interesse social ou a segurança das obrigações sociais, que caberia à jurisprudência determinar (Les sociétés..., cit., p. 309).

${ }^{497}$ Respectivamente, Les societés..., cit., p. 309 e Les limites..., cit., p. 18-40. Na página 19, a autora anota que a terminologia foi empregada pelos redatores do Código Civil de 1804, explicando em seguida que as verdadeiras limitações à autonomia contratual foram sendo construídas pela jurisprudência e impostas pelos legisladores. A partir da página 20, apresenta reflexão sobre a "difficulté de définir la notion d'ordre public", explorando, (i) a dificuldade de determinar as regras de ordem pública, (ii) a determinação, pelo legislador, 
A dificuldade inicial aparece ao se vincular a validade dos pactos parassociais ao respeito a regras imperativas do direito societário, já que não há critérios ou indícios claros, nos diversos ordenamentos, de quais seriam elas, apartando-as das regras dispositivas que podem ser alteradas ou desconsideradas pelas partes ${ }^{499}$.

De fato, a menos que o dispositivo legal em questão traga, em seu próprio texto, menção a seu caráter cogente, ele não será imediatamente reconhecido. No Brasil, bom exemplo de regra imperativa cujo reconhecimento é inegável e propiciado pela própria redação do dispositivo é o caput do art. 109, ao mencionar expressamente que "nem o estatuto social nem a assembléia-geral poderão privar o acionista dos direitos de: (...)"

Prosseguindo, obstáculo ainda maior se encontra com relação à definição dos princípios societários que não podem ser desrespeitados pelos pactos parassociais.

Em primeiro lugar, muitos desses princípios, embora reconhecidos pela doutrina e jurisprudência, não se encontram positivados, o que permite que, em interpretação estrita, argumente-se que não há, no caso, verdadeira proibição ou limitação à autonomia privada, a qual, pelo princípio da legalidade, somente pode ser restringida pela lei ${ }^{500}$.

do catáter de ordem pública de um texto, (iii) o monopólio do legislador na atribuição do poder de determinação da ordem pública, bem como (iv) a determinação do caráter de ordem pública de um texto pelo juiz. COPPER ROYER dedicou todo um capítulo em seu Traité des Societés ao problema, examinando os caminhos da jurisprudência francesa e lidando com a necessidade de definição do caráter imperativo de regras societárias (Chapitre VI - La notion d'ordre public, pp. 297-353).

${ }^{498}$ Nesse sentido, cf. Sophie SChiller, Les limites... cit., p. 38.

499 Adicione-se o percalço trazido pela discussão sobre a possibilidade de renúncia a direitos subjetivos pelo titular que seja o único beneficiário da proteção idealizada como regra de ordem pública. Cf. Sophie Schiller, cit., p. 40 e ss.; Michel Germain, La renonciation aux droits propres des associés: illustrations, in Mélanges en l'honneur du Pr. F. Terré, L’avenir du droit, Paris, Dalloz, 1999, pp. 401 - 413.

500 Segundo Sophie Schiller, os autores clássicos como Planiol, Ripert, Boulanger e CAPITANT, "considerando que a regra de ordem pública é capaz de restringir a liberdade das convenções - corolário do sistema instaurado com o Codigo Civil Francês - 
Além desse aspecto, na ausência de positivação, há a dificuldade em se reconhecer os princípios societários, bem como, aplicá-los no processo interpretativo ${ }^{501}$, elegendo qual deles deve preponderar em cada caso concreto $^{502}$.

Por razões dessa natureza, o respeito à ordem pública societária, abstratamente concebida, não se mostra como critério eficaz na apuração dos limites da autonomia contratual do direito societário e, por conseguinte, como índice de validade dos contratos parassociais patrimoniais e/ou elementos concretos para sua interpretação.

Nesse cenário, Sophie SCHILler, em sua pioneira e ousada obra Les limites de la liberté contractuelle en droit des sociétés propõe que o exame dos limites incidentes sobre a contratação, no direito societário, deve perquirir não sobre a obrigatoriedade de regras e princípios, mas "de certos elementos essenciais à matéria, no seu conjunto".

reconhecem esse poder apenas à lei, que seria a autoridade mais importante sobre a autonomia privada. Ou, na opinião de CAPITANT reproduzida pela autora, a noção de ordem pública seria muito ampla, devendo ser subordinada ao princípio de legalidade, na falta do qual a porta estaria aberta ao totalitarismo. No resumo de SCHILLER, essa posição pode ser compreendida sob a ótica individualista que prevalecia ao tempo em que foi emitida (no original, "cette position se retrouve dans les théories individualistes qui considèrent que la liberté des hommes ne peut être limitée dans l'intérêt commun que par des lois". Les limites..., cit., p. 23). Por sua vez, GÉRALdine GoffAuX-CAllebaut pondera, com propriedade, que "se na interpretação de fraude o juiz tiver uma concepção muito extensiva, isso pode atentar contra a liberdade e a segurança contratuais mas uma interpretação restritiva arrisca colocar em xeque a sistemática das regras de direito" (Du Contrat..., cit., p. 271).

501 Nesse sentido, como bem resume Comparato, "ao contrário do que comumente se imagina, os desvios de raciocínio jurídico não costumam provir de dificuldades no reconhecimento de exceções aos princípios, mas sim da não aplicação dos próprios princípios, mesmo os mais elementares" (Aparência de representação: a insustentabilidade de uma teoria” in RDM 111, p. 39).

502 Sobre a colisão entre princípios, cf. ERos RoBERTo GRAU, Ensaio e discurso sobre a interpretação/aplicação do direito, cit., p. 183. O autor ressalta que, havendo colisão, "a escolha do princípio há de ser feita, pelo intérprete (sempre diante de um caso concreto), a partir da ponderaçào do conteúdo do próprio princípio, ao passo que a declaração da validade de cada regra, diante de cada caso, depende da consideração de critérios formais, exteriores a elas". 
Isso porque "a identificação, no seio das regras existentes, daquelas que as partes não teriam o direito de dispor se revela impossível, tendo em conta a ausência de caráter operativo das noções de ordem pública e de regra imperativa" ${ }^{503}$, ao mesmo tempo em que não impede a formulação de pactos que, embora formalmente alinhados às regras constantes da lei, afrontam o direito societário em aspectos fundamentais ${ }^{504}$.

A autora considera, então, mais útil que examinar cada regra em sua individualidade, determinar, no direito societário, ligações fundamentais (que designa "conexxions radicales") que não podem ser rompidas, mesmo quando não haja formulação legal expressa a respeito dessa proibição ${ }^{505}$.

No estudo, Sophie Schiller examina duas dessas connexions radicales, aquela existente entre atividade e garantia ${ }^{506}$ e a verificada entre poder e responsabilidade ${ }^{507}$, esclarecendo que elas foram escolhidas pelos efeitos que

${ }^{503}$ Les limites...cit., p. 147.

${ }^{504}$ A ponderação feita por SCHILleR parece sintetizar o que se procura defender nesta tese: "Le droit des sociétés impose alors la présence de garanties dont l'organisation variera suivant la forme sociale choisie. La présence de conventions ou la mise em place d'um montage sociétaire peut permettre de faire disparaître toute garantie effective, tout em maintenant um parfait respect formel des règles impératives existantes. Une telle construction contractuelle doit être rejetée. (idem, p. 148)

${ }^{505}$ Idem, p. 149.

506 Em breve síntese, o primeiro binômio proposto, restaria justificado pelo fato de a própria gênese de qualquer sociedade ser determinada em função de uma atividade, que se desenvolverá envolvendo não apenas os sócios, administradores e empregados como também terceiros, demandando segurança jurídica. Ela então deve ser salvaguardada, protegida, garantida, menos no sentido patrimonial que no sentido de sua real e efetiva consecução (Idem, p. 150). Como exemplos de manifestações contratuais que podem atentar contra esse liame essencial, a autora indica aquelas relativas a participações recíprocas e auto-controle, a negociação com as próprias ações, ambas ligados ao tema da diluição ("watering") do capital social, incluindo as convenções que obtêm esses efeitos por meio de testas-de-ferro, participações indiretas ou circulares, bem como "cascata de sociedades" ou estruturas "piramidais" (idem, pp 346 a 380). De modo mais relevante para o argumento desta tese, a autora indica, ainda, como possíveis desvirtuadoras do binômio atividade/garantia as cláusulas de inalienabilidade e de restrição na circulação de ações (idem, pp. 381-388).

507 Já a ligação entre poder e responsabilidade decorre da assunção coletiva do risco e do princípio majoritário, que permite que o controlador oriente os rumos da sociedade e de sua atividade (idem, p. 181). A autora elenca entre os pactos ligados a essa preocupação aqueles que permitem a dissociação entre poder e responsabilidade como acordos entre usufrutuário e nu-proprietário (idem, p. 390), a locação de direitos sociais (p. 394), 
geram nas operações levadas a termo pela prática societária francesa, sendo certo que o rol das ligações fundamentais a proteger deverá ser ampliado "na medida em que a imaginação em matéria de engenharia societária se desenvolverá" ${ }^{508}$.

A iniciativa é louvável, na medida em que as reflexões e elementos trazidos pela autora seguem a linha de transpor o individualismo na análise da autonomia contratual no direito societário (i.e avaliar problemas não apenas pelo viés contratual), e, por consequência, coaduna-se com a proposta que, nesta tese, é dirigida à interpretação dos pactos parassociais.

\subsubsection{Conclusão}

Como já se adiantou no decorrer da explanação, os critérios geralmente apontados pela doutrina como limites à autonomia contratual no direito societário, à exceção da inovadora leitura de Sophie Schiller, são fundados em noções bastante amplas.

Por conseguinte, em que pese devam ser considerados na interpretação dos pactos parassociais patrimoniais, não contribuem, por si só, para que o processo interpretativo seja adequado à função econômica reservada a esses contratos.

A vagueza desses parâmetros (tipo societário das sociedades anônimas; interesse social e ordem pública societária) dificulta que, com relação ao caso concreto, o intérprete possa encontrar a justa medida entre a liberdade das

\footnotetext{
acordos sobre divisão de perdas, examinando a hipótese de pacto leonino (pp. 396 e ss); a "cascata de sociedades) (idem, p.403); cláusulas de garantias do passivo (pp. 405 e ss) e convenções que aumentam o poder, sem aumentar a responsabilidade, e vice -versa (idem, pp. 411 e ss)

${ }^{508}$ Idem, ibidem, nota 104.
} 
partes na determinação do conteúdo negocial e, de outro lado, as limitações que ela efetivamente deve sofrer ${ }^{509}$.

Por essa razão é que, nesta tese, optou-se por investigar elementos mais objetivos para informar a interpretação dos pactos parassociais patrimoniais: seja com base nas regras de hermenêutica do negócio jurídico testadas ao longo de decênios de experimentação prática; seja examinando-se a função econômica dos pactos em tela e a sua íntima ligação com a essência da noção de sociedade ${ }^{510}$ e com o status de sócio dos celebrantes.

\section{7 - Interpretação dos pactos parassociais patrimoniais e alvos de tutela do direito societário.}

Como última etapa ao se cogitar de elementos para a interpretação de pactos parassociais patrimoniais em coerência com sua função econômica e para além de seu exame pela exclusiva ótica do direito comum dos contratos, é preciso considerar os alvos de tutela do direito societário, em perspectiva, pois, teleológica.

Apontou-se na Introdução que o direito societário deve disciplinar as sociedades em vista dos variados grupos de interesse que a ela acorrem, principalmente os sócios/acionistas, os credores, e outros terceiros afetados por sua atividade. Nas companhias abertas, há a preocupação com os investidores e com a poupança popular.

\footnotetext{
${ }^{509}$ Cf. críticas de PEGgY LARRIEU, Interprétation des pactes extra-statutaires, cit. pp. 701711 .

510 SOPHIE SCHILleR também aventa esse caminho, antes de propor as conexões radicais (Les limites..., cit.p. 148 "En droit des sociétés, la façon la plus opératoire de procéder paraît être la déterminationde ce qui est essentiel dan toute société"). Para o âmbito dessa tese, porém, reputou-se prudente não avançar na investigação de semelhantes conexões no direito brasileiro, já que o esforço superaria o objetivo da tese, focada na interpretação dos pactos parassociais patrimoniais.
} 
Pela perspectiva da ordem jurídica do mercado ${ }^{511}$, a disciplina societária deve garantir que as relações dos titulares desses interesses - entre si e com a sociedade - sejam seguras, gerando confiança e previsibilidade quanto às formas societárias de exercício da atividade empresarial.

Em atenção a essa necessidade, o regramento legal incidente sobre os variados tipos societários foi se aperfeiçoando, buscando sempre melhor cumprir seu papel face à contínua evolução, na realidade fática, das sociedades comerciais. Da mesma maneira, princípios próprios foram se sedimentando, gerando verdadeiro ramo especial do direito, na acepção de ASCARELLI ${ }^{512}$.

$\mathrm{Na}$ medida em que os pactos parassociais patrimoniais são sempre mais utilizados para estruturar relações entre acionistas e formatar a realidade societária que entre eles existe, eles não podem fugir ao "radar" do direito societário, que, para evoluir em consonância aos clamos da prática, deve tomá-los em conta na formulação de garantias e proteções a seus alvos de tutela.

De outro lado, mesmo na ausência de regras positivadas que desnudem o liame necessário entre os pactos parassociais patrimoniais e os objetivos do direito societário, a interpretação desses ajustes deve examinar a coerência entre ambos ${ }^{513}$.

\footnotetext{
511 Como ensina Paula A. Forgioni, apoiada em Natalino Irti, o mercado é uma ordem que se baseia em comportamentos previsíveis e calculáveis. Assim, de comportamentos "leva à possibilidade de previsão do comportameto do outro agente e, com isso, uma ordem. Os agentes econômicos confiam que sua atuação (e a atuação dos outros será baseada em regras, de forma que o risco estará no sucesso ou insucesso da jogada, e nunca nas regras do jogo". Essa lógica de funcionamento do mercado enquanto ordem, pautada em normalidade, uniformidade e regularidade de comportamentos, explica "a razão de institutos que protegem o comportamento planejado na certeza de que o outro atuará conforme a regra (v.g. 'proteção da legítima expectativa', 'boa-fé', 'confiança')". A evolução do direito comercial..., cit., p. 230.

${ }^{512}$ Panorama do direito comercial, São Paulo, Saraiva, 1947, p. 24.

${ }^{513}$ Sobre essa necessidade, sustenta FRANÇOIS TERRÉ que para determinar a admissibilidade de ajustes incidentes sobre a relação societária, mais que apreciá-los isoladamente, pelo direito dos contratos, é preciso examiná-los no contexto em que se inserem para determinar
} 
E isso por uma necessidade de compatibilidade lógica com o sistema de direito societário. Se assim não fosse, pouco adiantaria formular regras protetivas (ex. direitos essenciais de acionista) se, pela pactuação, o mesmo dano puder ser causado, mediante a utilização de meios que, em princípio, não guardariam relação necessária com o direito societário (porque, como muito se diz na doutrina, eles não se referem à organização e ao funcionamento da sociedade).

Exemplo evidente do que se procura argumentar: a compra e venda de ações, por si, não é sujeita ao direito societário, dizendo respeito apenas ao patrimônio dos envolvidos, sendo-lhe aplicável o regramento geral dos contratos e obrigações. Todavia, quando sua utilização tem por efeito a exclusão de acionista, ela deve ser examinada à luz dos princípios societários de proteção ao acionista. O mesmo se diga das cláusulas de "lock in": o acionista pode abrir mão de alienar suas ações em certas condições, pois elas integram seu patrimônio, mas a interpretação do ajuste não pode levar a que ele reste obrigado a perpetuar-se na sociedade, o que seria afronta aos princípios societários que vedam o emprisionamento do sócio. Nesses casos, pois, em que pese inexistir efeito sobre a organização e funcionamento da companhia, é inegável a atuação do direito societário.

Diante da criatividade dos agentes, parece válida a sugestão de que a interpretação dos pactos parassociais patrimoniais devesse ser orientada, pois, pela caracterização da ilicitude dos pactos não tanto por seu objeto, que pode

se seus efeitos, eventualmente conjugados, são compatíveis ou não com os objetivos do direito societário, já que não sendo possível obter lista das regras societárias imperativas, cumpre verificar elementos da matéria em seu conjunto. ("[p]lutôt que d'apprécier isolément un aménagement du droit des sociétés par le droit des contrats, on réintégrerait cet aménagement dans un ensemble plus vaste. En d'autres termes, le caractère admissible des aménagements contractuels est déterminant suivant que leurs effets, éventuellement conjugués entre eux paraissent conformes ou non aux objectifs visés par le droit des sociétés. Et la détermination du caractère obligatoire ne s'opéré pas en posant une liste de règles impératives, mais en définissant certains éléments de la matière dans son ensemble". Prefácio à obra de SOPHIE SCHILleR, Les limites de la liberté contractuelle en droit des sociétés: les connexions radicales, Paris, LGDJ, 2002. Grifou-se). 
ser extremamente variado e, por si, lícito, mas por seus efeitos frente aqueles objetivos fulcrais da disciplina societária ${ }^{514}$.

Inexistindo regra legal específica, no Brasil, que delineie os efeitos a sancionar no direto societário ${ }^{515}$, o intérprete não escapa à necessidade de buscar, na jurisprudência e na doutrina brasileiras, quais são, no nosso ordenamento jurídico, os objetivos da disciplina societária a proteger.

Por essas razões, essa pauta de pesquisa deve receber maiores atenções da comunidade acadêmica, de modo que dos debates surjam contribuições para a formulação de regras específicas sobre a validade dos pactos parassociais patrimoniais em vista dos efeitos relevantes ao direito societário que possam produzir ${ }^{516}$.

Em suma, no contexto atual de utilização dos pactos parassociais patrimoniais ou não - seria recomendável que a disciplina legal não se restringisse ao disposto no art. 118 da lei 6.404/76, mas os tratasse como gênero e atentasse, com maior acuidade, à sua função econômica e aos potenciais efeitos frente aos interessados na tutela societária.

\footnotetext{
${ }^{514}$ A exemplo do que se verifica na legislação antitruste brasileira, já que também naquela esfera a criatividade dos agentes é marcante e a mera enunciação de atos ilícitos não abrangeria toda a possibilidade de dano à ordem econômica que se procura proteger. Cf., sobre essa opção legislativa, PAula A. Forgioni, Os Fundamentos do Antitruste, $3^{\mathrm{a}}$ ed., São Paulo, RT, p.147-150.

$515 \mathrm{Na}$ legislação antitruste, antes referida, essa enunciação foi realizada no art. 20 da lei $8.884 / 94$.

516 Como já comentado, Albuquerque Barreto esboça o problema ao apontar alguns limites de validade dos pactos parassociais sem, todavia, aprofundar o tema.
} 


\section{5 - CONCLUSÕES}

1. A contratualização do direito societário é fenômeno que, inegavelmente, tem se expandido e se intensificado nos diversos ordenamentos, sendo os pactos parassociais um de seus traços mais característicos. O estudo desses contratos geralmente não os enfoca sobre o ponto de vista do relacionamento societário de que os signatários são parte, o que demanda a análise de sua inafastável relação com a própria noção de sociedade e os princípios que a sustentam.

2. Ao se falar em pactos parassociais, em geral aparta-se, de um lado, aqueles que incidem diretamente sobre a organização e funcionamento da companhia (notadamente os acordos de voto) daqueles pactos que, em princípio, referem-se apenas a direitos patrimoniais dos celebrantes, enquanto sócios.

3. Os primeiros foram as manifestações originárias do fenômeno, havendo farta doutrina e preocupação constante de examinar seus efeitos societários. No segundo caso, porém, o fato de os efeitos obrigacionais do pactuado recaírem, em regra, apenas aos contratantes, acaba por permitir que se afirme que eles são regidos pela teoria geral dos contratos sem que a ressalva de que também devem respeito ao direito societário seja explorada. Por esse viés, no mais das vezes, subestima-se eventuais conseqüências societárias desses contratos.

No Brasil e na Itália muito dessa percepção advém do apego doutrinário à obra que originalmente designou os contratos parassociais como tais e enunciou as principais questões dogmáticas a eles ligados: Contratti Parasociali, escrita em 1942 por Giorgio Oppo. Nesse estudo - e em muitos que o seguiram, como se examinou na Introdução - o enfoque recai (i) no liame entre contrato social e parassocial, na coligação ou acessoriedade entre 
negócios jurídicos ${ }^{517}$ e (ii) nas ocorrências de pactos que geram efeitos para a companhia, ou seja, afastando-se do campo de análise os ajustes entre sócios a respeito do exercício de direitos que afetem, precipuamente, o seu patrimônio ${ }^{518}$.

Passados quase setenta anos da publicação obra de Oppo, porém, percebe-se que essa ótica, embora tenha contribuido significativamente para a análise teórica dos pactos parassociais no direito civil não seria suficiente para embasar análise que, em cada caso concreto, o intérprete deve realizar. De fato, os reclamos da prática societária e as questões jurídicas que suscitam não se encaixam, apenas, na relação entre contratos, mas antes demandam compreensão global do fenômeno societário que se sofistica sempre mais e que esses ajustem vêm disciplinar.

4. Para investigar o assunto sob a ótica proposta, foi necessário caracterizar, ainda que sucintamente, no Capítulo 2, os pactos parassociais patrimoniais de modo a separá-los dos contratos organizativos e políticos, com relação aos quais a doutrina societária de há muito se ocupa. Marcar essa distinção foi imprescindível para examinar como e sob qual justificativa também essas convenções firmadas entre particulares, que não possuem direto para a companhia, devem orientar-se pelos princípios societários.

Com esse intuito, apurou-se a função econômica desses pactos peculiares, matriz de toda interpretação contratual. Avaliou-se, então, que ela não poderia ser colhida em cada ajuste isoladamente considerado - como ocorre ao tratá-los apenas como meros contratos - mas a partir de sua inserção no relacionamento societário. Nessa perspectiva, a função econômica dos pactos parassociais patrimoniais exsurge como aquela de personalizar e

\footnotetext{
${ }^{517}$ Giorgio Oppo, Contratti Parasociali, cit., p. 2.

${ }^{518}$ Como se enfatizou, esses contratos que não incidem diretamente sobre a organização e funcionamento da companhia, na leitura de OPPO, são vistos como mero fato, o que dispensaria a necessidade do exame da sua conexão com o contrato de sociedade. Evidencia-se, nesse peculiar, a diferença do estudo ora realizado, que parte da função da pactuação parassocial para o relacionamento entre os sócios (Contratti... cit., pp. 7-8).
} 
estruturar esse relacionamento, por meio do regramento de direitos patrimoniais de seus partícipes, incidentes sobre sua esfera jurídica.

5. Nesse exame se constatou que, no cumprimento de sua função econômica, as disposições dos pactos em exame não apenas geram vínculos obrigacionais entre os signatários - como muito se salienta, mas também gravam o status de sócio de cada um deles. A ênfase da doutrina em referir que os efeitos do pacto limitam-se às partes contratantes seria justificada, assim, pela necessidade de se evidenciar as diferenças formais entre contrato social e parasocial (regras de constituição, publicidade etc) e com vistas à disciplina da oponibilidade do contratado perante a companhia, permitida, de forma ímpar, no direito brasileiro. Não se enfatiza, porém, de maneira contundente, que essas considerações não têm por efeito afastar a incidência, sobre os pactos parassociais, do direito societário. Por consequência, procurou-se insistir nesse aspecto tão relevante ao tema.

6. Todas as circunstâncias acima expostas influenciam, inexoravelmente, o processo de interpretação dos pactos parassociais patrimoniais sem que se encontrasse, no Brasil, obras voltadas especificamene ao problema, apontando, para o intérprete, balizas a considerar. Assim, objetivo desta tese foi de investigar e apontar elementos que devem orientar o processo de interpretação dos pactos parassociais patrimonias, em vista de sua pertinência ao relacionamento societário existente entre os pactuantes.

7. Em primeiro lugar, partiu-se da constatação de que, na legislação brasileira, a par da regra geral de interpretação dos negócios jurídicos ${ }^{519}$, não há regras sobre a interpretação dos pactos parassociais, em geral, ou mesmo sobre a relação entre os pactos parassociais e a disciplina societária. Ao prever no art. 118 da lei 6.404/76 os acordos de acionistas, espécie de pacto parassocial que pode disciplinar o direito de voto, exercício do poder de controle e a compra e venda de ações, o legislador brasileiro deu ênfase a dois

\footnotetext{
${ }^{519}$ Art. 113 do Código Civil.
} 
aspectos peculiares: a execução específica do contratado, em linha com a legislação processual, e a oponibilidade do acordo perante a companhia e terceiros. Por decorrência, a nossa produção acadêmica centra-se no exame de temas correlatos aos acordos de acionistas, especialmente no que toca aos acordos de voto e controle, e as formas de vinculação da companhia. No Capítulo 3, verificou-se a relação entre a disciplina legal existente e a interpretação dos pactos parassociais patrimoniais, bem como a consequência de muitos deles não se englobarem naqueles mencionados em lei: os pactos parassociais patrimoniais que não se referem à compra e venda de ações e preferência para adquiri-las não são oponíveis a terceiros, valendo apenas entre as partes. Todavia, como qualquer contrato, produzem efeitos reflexos a terceiros os quais podem não ser aceitáveis sob a ótica societária.

8. A seu turno, a jurisprudência sobre o tema é míngua, espécie no que se refere a ajustes que não se identificam com acordos de voto, não sendo possível dela extrair princípios ou lineamentos sobre necessária submissão dos pactos parassociais patrimoniais aos ditames do direito societário, que pudessem orientar a interpretação ${ }^{520}$.

9. Nesse contexto, procurou-se, a partir da função econômica dos pactos parassociais patrimoniais delineada no Capítulo 2, avaliar alguns elementos que pudessem servir de norte para o intérprete, de modo a incluir no processo hermenêutico considerações ligadas à própria lógica societária a que esses contratos devem servir.

Ou seja, elementos que servissem para afastar a apressada conclusão de que os pactos de conteúdo patrimonial seriam alvo de irrestrita liberdade contratual das partes, no pleno gozo de seu direito de propriedade sobre os objetos da contratação.

\footnotetext{
${ }^{520}$ Exceção necessária se deve fazer ao acórdão do STJ sobre o caso Petroplastic, em que essa relação foi apontada.
} 
10. No Capítulo 4, pois, em um primeiro lance, voltou-se a elementos fundados nas regras consagradas de hermenêutica, que determinam a necessidade de exame da função econômica do contrato, da intenção comum das partes e da boa-fé objetiva para resultado idôneo, consentâneo com as legítimas expectativas geradas pelo negócio. Como conclusão dessa análise, parece possível enunciar que a interpretação dos pactos parassociais patrimoniais:

a) não pode desconsiderar a causa societária que irmana os pactuantes, ou seja, tratar esses contratos como se as partes não se encontrassem vinculadas em sociedade, não fossem sócias;

b) deve realizar-se com base nas circunstâncias da associação societária entre as partes e o contexto global em que o contrato foi celebrado, apurando-se o complexo quadro fático e negocial que sempre mais caracteriza as relações societárias;

c) deve pautar-se pela boa-fé objetiva, concretamente apurada com base no relacionamento societário que envolve as partes, em respeito da confiança e da legítima expectativa entre elas, pautadas pela affectio societatis, ou seja, pelo estado de ânimo colaborativo que as leva a cooperar em vista de um escopo comum.

11. Ademais, todos esses aspectos devem ser considerados em vista de outros elementos, imprescindíveis à sustentação da lógica societária: o escopo comum, os deveres de lealdade, a vedação de pacto leonino e os direitos dos sócios. Com relação a eles, pois, concluiu-se que:

a) alicerce da noção de sociedade, o escopo comum orienta todas as relações emanadas do contrato de sociedade ou, na expressão de Wiedemann, é a lei vital da sociedade a que as partes, voluntariamente, sujeitam-se; 
b) o escopo comum assinala aos sócios, pois, deveres de conduta, pautados na relação fiduciária que entre eles deve existir, independente de previsão legal. São deveres laterais de conduta, que ultrapassam a obrigação primária do sócio de contribuir com recursos para a formação do capital social. A partir do direito alemão, esses deveres são designados deveres de lealdade (Treuepflichten) e voltam-se tanto para a conduta do sócio perante a companhia como - e especialmente para o argumento da tese perante os demais sócios.

c) Nesse sentido, os deveres de lealdade servem de pauta de avaliação da conduta dos sócios, examinando a sua adequação frente aquela específica relação societária que estabeleceu com os demais em vista de um escopo comum, valendo-se, inclusive, de convenções parassociais patrimoniais.

d) Por consequência, a interpretação de pactos parassociais patrimoniais deve levar em conta o respeito a esses deveres coibindo resultados que atentem contra o escopo comum a ser perseguido. Essa necessidade é verificada mesmo que (e especialmente quando), aparentemente, o objeto do contrato refira-se a direitos individuais e patrimoniais do celebrante, sem impacto direto para a companhia. A conduta do sócio globalmente considerada deve coadunar-se a esses deveres, e não apenas os atos societários refletidos diretamente na companhia como o voto, a participação em assembléia, a administração e a fiscalização da atividade social.

e) Ainda em vista de fundamentos da noção de sociedade, a vedação do pacto leonino também decorre da ideia de submissão das partes ao escopo comum, já que não faria sentido assinalar escopo comum a todos se uma das partes (i) colhesse sozinha seus frutos; (ii) não participasse das perdas verificadas na realização da 
atividade ou mesmo (iii) restasse isenta do risco inerente à atividade. Por esse viés, a interpretação dos pactos parassociais patrimoniais deve avaliar se eles têm por efeito a burla das regras proibitivas dos pactos leoninos, ainda que, formalmente, afigurem-se como contratos válidos sob a perspectiva da teoria geral dos contratos. No Brasil, o pacto leonino é sancionado de nulidade, conforme o art. 1.008 do Código Civil.

f) por fim, os direitos de sócio são vitais para a convivência societária, não podendo ser suprimidos. A interpretação dos pactos parassociais deve, então, avaliar se suas disposições afetam esses direitos, já que o art. 109 da Lei 6.404/76 limita expressamente a autonomia das partes com relação a eles. Como exemplos de direitos passíveis de afronta por pactos parassociais patrimoniais, aponta-se o direito de não restar prisioneiro da sociedade; o direito a permanecer associado e o direito a não ter sua participação diluída injustificadamente.

g) Quanto ao direito de não restar prisioneiro da sociedade, a atenção se volta a pactos relativos à restrição na circulação de ações, como os ajustes de direito de preferência, consentimento e permanência, aos quais se contrapõe o direito de recesso ou retirada do acionista.

h) Sobre o direito de se manter associado, os pactos de opção de compra devem ser examinados de sorte a apurar se a exclusão do acionista por elas perpetrado é coerente com sua tutela ou se, ao revés, impõe-se expropriação ao acionista vinculado.

i) Por fim, a interpretação de pactos parassociais patrimoniais que prevejam regras de capitalização e financiamento da sociedade deve considerar se o acionista a que elas se sujeita terá tido condições de manifestar as condições em que aceita ver sua 
participação acionária reduzida ou se, ao contrário, há renúncia genérica e tácita - inadmissível - a esse seu direito.

12. Enunciados os elementos que se pode colher do exame da função econômica dos pactos parassociais patrimoniais e sua inserção na relação societária, cerne do presente trabalho, avaliou-se elementos tradicionalmente apontados na doutrina como limitadores da autonomia contratual, quais sejam (i) a tipicidade social, (ii) o interesse social e (iii) a ordem pública societária. A vagueza desses termos, contudo, faz com que pouco orientem, em concreto, o intéprete, corroborando a utilidade de critérios mais objetivos como os apontados nos itens precedentes.

13. Como reflexão final, a envolver os tópicos precedentemente desenvolvidos, cuidou-se da necessidade de a interpretação dos pactos parassociais patrimoniais guardar coerência com os objetivos do direito societário que, sucinta e genericamente, podem ser indicados como a proteção dos sócios, dos credores e de terceiros afetados pela relação societária. Ou seja, reforça-se a necessidade de, no exame dos pactos parassociais patrimoniais, valer-se de perspectiva teleológica.

No estágio atual do direito brasileiro, contudo, o intérprete não encontra toda a consolidação teórica, legislativa ou jurisprudencial para lhe indicar, de forma concreta e sistemática, quais os objetivos que o direito societário pátreo persegue e, por conseqüência, quais efeitos e danos potencialmente gerados pelos pactos parassociais patrimoniais se deva coibir.

Frente a essa dificuldade, entendeu-se conveniente sugerir que a legislação societária brasileira passe a contar com disciplina mais abrangente dos pactos parassociais - patrimoniais ou não - caracterizando sua eventual ilicitude pelos efeitos gerados na órbita do direito societário.

Optando-se por essa linha, seria necessário indicar, a exemplo do que ocorre na legislação antitruste brasileira, tanto os alvos de proteção da 
disciplina quanto os efeitos que ela deve reprimir. O benefício deste caminho seria o de oferecer disciplina que, afinal, fizesse frente à criatividade dos agentes que, na prática societária, buscam os contratos parassociais para regular seu relacionamento societário.

14. Naturalmente, outros elementos que não aqueles referidos nos itens 10 e 11, acima, podem e devem ser considerados para a interpretação dos pactos parassociais patrimoniais e não se teve a pretensão de esgotá-los.

Ao contrário, não se tendo encontrado manifestações doutrinárias que tenham tratado do mesmo assunto, sob a mesma ótica, o objetivo foi o de trazer a lume essas reflexões e sugestões, com vistas a aproximar do direito societário o exame dos contratos parassociais patrimoniais. Cuidando-se de proposta inexplorada, anseia-se que outros estudos possam aperfeiçoar e corrigir as inevitáveis falhas ou lacunas presentes neste trabalho. 


\section{REFERÊNCIAS BIBLIOGRÁFICAS}

AAVV., Temas de Direito Societário e Empresarial Contemporâneos Liber Amicorum Prof. Dr. Erasmo Valladão Azevedo e Novaes França, São Paulo, Malheiros, 2011.

AAVV., Travaux de L'association Henri Capitat pour la Culture Juridique Française, T. X - Les consortiums d'actionnaires et la protection des minorités dans les sociétés anonymes (Journée de Berne). Vente à tempérament (Journée de Neuchatel), Paris, Librarie Dalloz, 1956.

ABREU, Luis Vasconcelos, A sociedade leonina (art. 994. ${ }^{\circ}$ do Código Civil), in Revista da Ordem dos Advogados, n. ${ }^{\circ}$ 56, II, agosto 1996, pp. 619-665.

ALVARENGA, Maria Isabel de Almeida, Impossibilidade de resilição unilateral de acordo de acionistas por prazo indeterminado (comentário ao acórdão do Tribunal de Justiça do Estado de São Paulo na Apelação Cível n. 211.924.1/4), in RDM 108, 1997, pp. 18696.

ALVARENGA, Maria Isabel de Almeida, Finalidades do direito de preferência para a aquisição de ações in AAVV. Temas de Direito Societário e Empresarial Contemporâneos.Liber Amicorum Prof. Dr. Erasmo Valladão Azevedo e Novaes França, Malheiros, São Paulo, 2011, pp. 472-491.

AMIAUD, André, L'evolution du droit des sociétés par actions, in Mélanges Ripert, vol. 2, Paris, Dalloz, 1950.

AMORIM, Ricardo Martins, A resposta do Poder Judiciário brasileiro para o conflito entre disposições de acordo de acionistas e estatuto social: comentários a um litígio judicial, in RDB 35, 2007, pp. 107-21.

ARAúJo COSTA, Salustiano Orlando de, (o Conselheiro Orlando), Codigo Commercial do Imperio do Brazil, Rio de Janeiro, Laemmert, 1864.

ARMOUR, John et al., The essential elements of corporate law, Law working paper, n. ${ }^{\circ} 134, \quad 2009$, disponível em: http://ssrn.com/abstract=1436551.

ASCARELli, Tullio, Problemi giuridici, Vol. 1, Milano, Giuffrè, 1959.

ASCARELLI, Tullio, Interesse sociale e interesse comune nel voto, in Rivista Trimmestrale di Diritto e Procedura Civile, 1951, pp. 114567.

ASCARELli, Tullio, Panorama do direito comercial, São Paulo, Saraiva, 1947. 
ASCARELli, Tullio, Problemas das sociedades anônimas e direito comparado, São Paulo, Saraiva, 1955.

ASCARELLI, Tullio, Saggi di diritto commerciale, Milano, Giuffrè, 1955.

ASCARELli, Tullio, Saggi giuridici, Milano, Giuffré, 1949.

ASCARELli, Tullio, Studi in tema di Società, Milano, Giuffrè, 1952.

ASCARELLI, Tullio, Tipologia delle societá per azioni e disciplina giuridica, in Rivista delle Societá, 1959, pp. 1015-90 [= Problemi Giuridici, v. II, Milano, Giuffrè, 1959, pp. 1001 e ss.]

ASCARELLI, Tullio, Usos e abusos das sociedades anônimas, in Revista Forense, n. ${ }^{\circ} 88,1941$, pp. 5-33.

ASQUINI, Alberto, Le azioni privilegiate a voto limitato, in Rivista delle Società, 1961, pp. 945 e ss.

ASQUINI, Alberto, I batelli del Reno, in Rivista delle Societá (1959), pp. $616-44 .$.

AULETTA, Giuseppe, Il contratto di società commerciale: requisiti, conclusioni, vizi, Milano, Giuffrè, 1937.

AZARA, Antonio e EULA, Ernesto (coord.), Novissimo Digesto Italiano, Torino, UTET, 2010.

AZAVANT, Marc, La sanction civile en droit des sociétés ou l'apport du droit commun au droit spécial, in Revue des Sociétés, n.o 3, julho setembro, 2003, pp. 442-78.

AZEVEDO, Álvaro Villaça, Teoria geral dos contratos típicos e atípicos, São Paulo, Atlas, 2002.

BALASSIANO, Evelyn, Acordo de acionistas: possibilidade de resilição unilateral e suas restrições, in RTDC 30, 2007, pp. 27-52.

BAPTISTA, Luiz Olavo, A “Joint Venture” - Uma perspectiva comparatista, in RDM 42, 1981, pp. 39-59.

BARBI FILHO, Celso, Acordo de acionistas, Belo Horizonte, Del Rey, 1993.

BARBI FILHO, Celso, Acordo de acionistas: panorama atual do instituto no direito brasileiro e propostas para a reforma de sua disciplina legal, in RDM 121, 2001, pp. 30-55.

BARBI FILHO, Celso, Efeitos da reforma do Código de Processo Civil na execução específica do acordo de acionistas, in RDM 109, 1998, pp. 17-38.

BARRETO DE ARAGÃO, Salvador Antonio Moniz, Sociedades anonymas, Rio de Janeiro, Francisco Alves, 1914. 
BARRETO, Celso de Albuquerque, Acordo de Acionistas, Rio de Janeiro, Forense, 1982.

BARRIÈRE, François, Ordre public et impérativité: observations en droit pénal des sociétés anonymes, in Revue des Sociétés, n. ${ }^{\circ}$, outubro dezembro, 2007, pp. 713-31.

BARROSO, Carlos Henrique, A responsabilidade civil do conselheiro de administração e o acordo de acionistas, in RT 834, 2005, pp. 44-57.

BAUS, Matthias, Treuepflichten des Aktionärs im Gemeinschaftsunternehmen, in Europäische Hochschulschriften, rechtswissenschaft, vol. 1052 (SD), Frankfurt am Main, Peter Lang.

BEBCHUK, Lucian Arye, Limiting contractual freedom in corporate law: the desirable constraints on charter amendments, in Harvard law review, vol. 102, n. ${ }^{\circ} 8$, pp. 1820-60, 1989, disponível em: http://papers.ssrn.com/abstract_id=415320.

BEBCHUK, Lucian Arye, The debate on contractual freedom in corporate law, in John M. Olin center for economics, and business Discussion paper, n. ${ }^{\circ}$ 63, 1989, pp. 01-23.

BELlantUONO, Giuseppe, I contratti incompleti nel diritto $e$ nell'economia, Padova, Cedam, 2000.

BENTO DE FARIA, Antonio, Codigo Commercial brazileiro, Rio de Janeiro, Ribeiro dos Santos, 1903.

BERTOLDI, Marcelo M., Acordo de acionistas, São Paulo, RT, 2006.

BERTREL, Jean-Pierre, Liberté contractuelle et sociétés, in Revue Trimestrielle de Droit Commercial, 1996, pp. 595 e ss.

BESSONE, Darcy, Acordo de acionistas. Poderes do acionista controlador de sociedade anônima. Artigos 116, 238 e 273 da Lei 6.404/76, in RT, vol. 672, outubro 1991, pp. 21-46.

BEVILAQUA, Achilles, Sociedades anônimas e em comandita por ações, $3^{a}$ ed. Rio de Janeiro, Freitas Bastos, 1951.

BISSARA, Philippe, L'inadaptation du droit français des sociétés aux besoins des entreprises et les aléas des solutions, in Revue des Sociétés, 1990, pp. 553 e ss.

BITTAR, Carlos Alberto, Contratos Parassociais (Acordos entre acionistas), in Enciclopédia Saraiva do Direito, n. ${ }^{\circ}$ 20, (SD), pp. 168-71.

BLACK, Bernard e KRAAKMAN, Reinier, A self-enforcing model of corporate law, in 109 Harvard Law Review, 1996, pp. 1911-1982, disponível em: http://papers.ssrn.com/paper.taf?abstract_id=10037. 
BLACK, Bernard S. et al, General principles of company law for transition economies, in 24 Journal of Corporation Law, 1999, pp. 190-293, disponível em: http://papers.ssrn.com/paper.taf?abstract_id=126539.

BLACK, Bernard S., Is Corporate law Trivial?: A Political and Economic Analysis, Northwestern University Law Review, Vol. 84, n. ${ }^{\circ}$ 2, 1990, pp. 543-593.

BOILlot, Christine, Pacte d'actionnaires. Transaction. Force obligatoire. Opposabilité aux tiers. Note: L'opposabilité des transactions: source fréquente de litiges, in Bulletin Joly Sociétés, julho, 2009, pp.687690 .

BROSETA PONT, Manuel, Manual de derecho mercantil, vol. 1, 14 a ed., Madrid, Tecnos, 2007.

BROSETA PONT, Restricciones estatutarias a la libre transmisibilidad de acciones, Madrid, Tecnos, 1963.

BRUNETTI, Antonio, Trattato del diritto delle società, $2^{\mathrm{a}}$ ed., Milano, Giuffrè, 1948 .

BULGARELLI, Waldirio, A proteção às minorias na sociedade anônima, São Paulo, Pioneira, 1977.

BULGARELLI, Waldirio, A regulamentação jurídica do acordo de acionistas, no Brasil, in RDM 40, 1980, pp. 79-100

BULGARELLI, Waldirio, Anotações sobre o acordo de cotistas, in RDM 98, 1995, pp. 44-49.

BULGARELLI, Waldirio, Validade de disposiçôes de acordo de acionistas de votarem em bloco, assegurando a política gerencial única $e$ necessária (Parecer), in RDM 123, 2001, pp. 185-7.

BULHÕES PEDREIRA, José Luiz, Acordo de acionistas sobre controle de grupo de sociedades - Validade da estipulação de que os membros do Conselho de Administração de controladas devem votar em bloco segundo orientação definida pelo grupo controlador (Parecer), in RDB 15, 2002, pp. 226-48.

BUTTARO, Luca, Sindacati azionari, in Novissimo digesto italiano, diretto da AZARA, Antonio e EULA, Ernesto, XVII, Torino, Vnione tipografico e Editrice Torinese, SD, pp. 425-30.

CALVOSA, Lucia, L'emissione di azioni riscattabili come tecnica di finanziamento, in Rivista del Diritto Commerciale, 2006, pp. 195208. 
CAMARGO VIDIGAL, Geraldo e SILVA MARTINS, Yves Gandra (coords.), Comentários à lei das sociedades por ações (Lei 6404/76), vol. 1, São Paulo, IASP/Resenha Universitária, 1978.

CAMILletti, Francesco, Considerazioni sui sindacati di voto e sulle deliberazioni assunte in conflitto di interessi, in Rassegna di Diritto Civile, n. ${ }^{\circ}$ 4, 1998, pp. 721-32.

CAMpos BATAlHA, Wilson de Souza, Comentários à Lei das Sociedades Anônimas, Vol. 2, Rio de Janeiro, Forense, 1977.

CANNU, Paul Le, Convention réglementée non révélée au conseil de surveillance et à l'assemblée: notion de partie à la convention, préjudice et presciption de l'action en responsabilité (Cass. com., 28 févr. 2006, pourvoi $n^{\circ}-11.768$ ), in RTDCom (outubro - dezembro 2006), pp. 867-69.

CANNU, Paul Le, Validation de la clause buy or sell, et durée des pactes d'actionnaires (CA Paris, 3e ch. B, 15 déc. 2006, CMP, STIM et CGTH c/ SNCM et CMN, D. 2007. AJ 162), in RTDCom, janeiro março, 2007, pp. 169-74.

CANNU, Paul Le; DONDERO, Bruno, "Package" du mandataire social et conventions réglementées (Soc. 8 juill. 2009, pourvoi no 08-41.589, arrêt $n^{o} 1607$ FS- D, JCP E 2009. 2034, note Y Paclot), in RTDCom, outubro - dezembro, 2009, pp. 762-64.

CAPPIELLI, Stefano, Prospettive di riforma del diritto di recesso dalle società di capitali: fondamento e limiti dell'autonomia statutaria, in Rivista del Diritto Commerciale e del Diritto Generale delle Obbligazioni, vol. 99. n. 5/8, pp.243-97, março - agosto, 2001.

CARBONETTI, Francesco, I patti parasociali nelle societa non quotate alla luce del testo unico della finanza, in Rivista delle Società, n. ${ }^{\circ} 43$, 4, 1998, pp. 909-17.

CARIELLO, Vincenzo, La banca commerciale italiana e il controllo delle societa mediante accordi parasociali (1918-1933), in Rivista del Diritto Commerciale e del Diritto Generale delle Obbligazioni, n. ${ }^{\circ}$, 1/2, 1998, pp. 29-57.

CARIELLO, Vincenzo, Controllo congiunto e accordi parasociali, Milano, Giuffrè, 1997.

CARNEIRO DA FRADA, Manuel A., Contrato e deveres de proteção, Coimbra, Almedina, 1994, p.143.

CARNEIRO DA FRADA, Manuel A., Acordos parassociais "omnilaterais": um novo caso de "desconsideração" da personalidade jurídica?, in Direito das Sociedades em Revista, vol. 2, outubro, 2009, pp. 97-135. 
CARVALHO DE MENDONÇA, José Xavier, Tratado de direito commercial brazileiro, Vol. 1, 1ª ed., São Paulo, Cardozo Filho, 1910.

CARVALHO DE MENDONÇA, José Xavier Tratado de direito comercial brasileiro, Rio de Janeiro, Freitas Bastos, 1934.

CARVALHO DE MENDONÇA, José Xavier, Pareceres, Rio de Janeiro, Freitas Bastos, 1934.

CARVALHO DE MENDONÇA, José Xavier, Problemas das sociedades anonymas, São Paulo, RT, 1931.

CARVAlhosA, Modesto, Comentários à lei das Sociedades Anônimas, vol.2, $3^{\text {a }}$ ed., São Paulo, Saraiva, 2003.

CARVAlhoSA, Modesto, Acordo de Acionistas - Homenagem a Celso Barbi Filho, São Paulo, Saraiva, 2011.

CARVAlhoSA, Modesto, Acordo de acionistas, São Paulo, Saraiva, 1984.

CARVAlhOSA, Modesto, Acordo de acionistas, in RDM 106, 1997, pp. 20-24.

CARVAlhoSA, Modesto, Eficácia e execução específica do acordo de acionistas, in Revista da EMERJ 26, 2004, pp. 125-32.

CASELLI, Giovanni, Azioni privilegiate e partecipazione alle perdite, in Giurisprudenza Commerciale, n. ${ }^{\circ} 1,1980$, pp. 682 e ss.

CERATI-GAUTHIER, Adeline, Pactes d'acionnaires. Entreprises em difficulté. Société mise em redressement judiciaire. Incidence sur le droit de préemption. Note:L'efficacité d'um pacte d'actionnaires em dépit de l'ouverture d'une procédure de redressement judiciaire contre la société, in Bulletin Joly Sociétés, agosto, 2004, pp.10771088 .

CERONI, Cristina, Simulazione e patti parasociali, in Rivista Trimestrale di Diritto e Procedura Civile, n. ${ }^{\circ}$ 44, 4, 1990, pp. 1111-61.

CERRAI, Alessandro e MAZZONI, Alberto, La tutela del socio e delle minoranze, in Rivista delle Società, 1993, pp. 1-90.

CHAMPAUD, Claude, Le contrat de societé existe-t-il encore?, in Le Droit Contemporain des Contrats bilan et perspectives (sd), Coord. CADIET, Loïc, Travaux et Recherches, Serie Faculté des Sciences Juridiques de Rennes, Paris, Economica, pp. 125-139.

CHAMPAUD, Claude, Le pouvoir de concentration de la société par actions, Paris, Sirey, 1962.

CHAMPAUD, Claude; DANET, Didier, Associé désirant quitter la société. Estimation de la valeur de ses droits sociaux. Application d'un convention particulère de rachat. Condition de validité. 
Détermination expertale de l'article 1843-4 du code civil. Absence d'obligation de préemption à défaut de présentation d'un cessionnaire à la société (Paris, 1re ch. A, 30 oct. 2007, Sanchez. Ruiz c/ Sté Arts sans Frontières et Sté MCW), in RTDCom, janeiro março. 2008, pp. 127-28.

CHAMPAUD, Claude; DANET, Didier, Clause léonine. Pacte d'actionnaires. Promesse de rachat d'actions. Prix minimum. Caractère léonin (non) (Com. 16 nov. 2004, Belkhelfa et autre c/ Rossler), in RTDCom, janeiro - março, 2005, pp. 111-16.

CHAMPAUD, Claude; DANET, Didier, Contrat et société. Pacte d'actionnaire. Clause de sortie conjointe. Augmentation de capital. Cession au nouvel actionnaire. Application de la clause de sorite conjointe (non) (Paris 6 juill. 2004, Sté Civile Consultants Associés c/ Sté Harrison et Wolf), in RTDCom outubro - dezembro, 2004, pp. 744-46.

CHAMPAUD, Claude; DANET, Didier, Location de parts ou d'actions de sociétés (Décret $n^{o}$ 2006-1566 du 11 déc. 2006, JO 12 déc.), in RTDCom, janeiro - março, 2007, pp. 139-40.

CHAMPAUD, Claude; DANET, Didier, Pacte de portage. Promesse unilatérale d'achat souscrite par les associés en faveur du porteur. Levée de la promesse au prix fixé pour acquérir des droits sociaux portement dépréciés. Affranchissement, de fait, du porteur de son obligation de contribuer aux pertes. Pacte léonin (non,) Com. 22 févr. 2005, J. Gontard c/ Papelier et a., in RTDCom, abril - junho, 2005, pp. $144-46$.

CHAMPAUD, Claude; LE FLOCH, Paul, Sociétés et autres groupements, in Revue Trimestrielle de Droit Commercial et de droit économique, Tomo XXXXI, 1988, pp. 62-76.

CHAPUT, Yves, La liberté et les statuts, in Revue des Sociétés, 1989, pp. 361 e ss.

CHIAPETTA, Francesco, I patti parasociali nel Testo Unico delle disposizioni in materia di intermediazione finanziaria, in Rivista delle Società, 1998, pp. 988-1012.

CLAUDEL, Emmanuelle, Clauses léonines extra-statutaires, les vois d'un compromis, in Mélanges Jeantin: prospectives du droit économique, Paris, Dalloz, 1999.

COFFEE JR., John C. e BERLE, Adolf. A., The future as history: the prospects for global convergence in corporate governance and its implications, in The Center for Law and Economic Studies Working 
Paper, $\quad .^{\circ} \quad 144, \quad 1999, \quad$ disponível em: http://papers.ssrn.com/paper.taf?abstract_id=142833.

COHEN, Daniel, La légitimité des montages en droit des sociétés in Mélanges en l'honneur du Pr. F. Terré, L'avenir du droit, Paris, Dalloz, 1999.

COMPARATO, Fábio Konder e SALOMÃO FILHO, Calixto, O poder de controle na sociedade anônima, $4^{\mathrm{a}}$ ed., Rio de Janeiro, Forense, 2005.

COMPARATO, Fábio Konder, O poder de controle na sociedade anônima, $3^{\text {a }}$ ed., Rio de Janeiro, Forense, 1983.

COMPARATO, Fábio Konder, Poder de controle na sociedade anônima, in RDM 9, 1973, pp. 67-75.

COMPARATO, Fábio Konder, Novos ensaios e pareceres de direito empresarial, Rio de Janeiro, Forense, 1981.

COMPARATO, Fábio Konder, Direito empresarial: estudos e pareceres, São Paulo, Saraiva, 1990.

COMPARATO, Fábio Konder, A natureza da sociedade anônima $e$ a questão da derrogabilidade das regras legais de "quorum" nas assembléias gerais e reuniões do conselho de administração, in RDM 17, 1978, pp. 89-98.

COMPARATO, Fábio Konder, Acionista controlador, in I Ciclo de conferência para magistrados da EMERJ, Rio de Janeiro, IBCB, 1993.

COMPARATO, Fabio Konder, Funções e disfunções do resgate acionário, in RDM 73, 1989, pp. 66-73.

COMPARATO, Fabio Konder, Nota sobre a execução específica da obrigação de contratar, in RDM 97 pp. 104-107.

COMPARATO, Fabio Konder, Aparência de representação: a insustentabilidade de uma teoria” in RDM 111 pp. 39-44.

COMPARATO, Fabio Konder, Notas sobre a resolução dos contratos, in RDM 43, 1981,pp. 79-85.

COMPARATO, Fábio Konder, Reflexões sobre as promessas de cessão de controle societário, in RDM 32, 1978, pp. 77-89.

CONSTANTIN, Alexis, Pacte d'actionnaires. Licenciement soumis à autorisation $d u$ conseil de surveillance. Incidence sur les droits des salariés. Note: Opposabilité d'un pacte d'actionnaires par un salarié licencié, in Bulletin Joly Sociétés, Setembro, 2009, pp.786 - 791. 
CONSTANTIN, Alexis, Sociétés en général: La clause de non-concurrence souscrite dans un pacte extrastatuaire, in Revue trimestrielle de droit commercial et de droit économique, n. ${ }^{\circ}$ 2, abril - junho, 2011, pp. 361365 .

CONVERT, Laurent, L'impératif et le supplétif dans le droit des sociétés. Étude de droit comparé: Angleterre - Espagne - France, Paris, LGDJ, 2003.

COPPER ROYER, Edouard, et. all., Traité des sociétés. Príncipes généraux et leur application à la matiere des sociétés, Tome II -, Paris, Sirey, 1938.

CORAPI, Diego, Gli statuti delle società per azioni, Milano, Giuffrè, 1971.

CORAPI, Diego, Regras obrigatórias e facultativas na lei das sociedades, in Revista de Direito Bancário e do Mercado de Capitais, n. ${ }^{\circ} 23$, janeiro - março, 2004, pp. 131-41.

CORAPI, Diego, Unificazione e armonizzazione del diritto societario in Europa, in Revista da Faculdade de Direito da Universidade de São Paulo 92, janeiro - julho, 1997, pp. 281-300.

CORDONNIER, Paul, L'actionnaire peut-il céder son droit de vote? in Journal des Sociétés, 1927, pp.5-33.

CORRADO, Diego, II dirito delle società tra autonomia dei privati $e$ intervento del legislatore, in RDM 131, 2003, pp. 21-43.

CORREA LIMA, Osmar Brina, Direito de voto na sociedade anônima, in RT, vol. 530, dezembro 1979, pp. 26-37.

COSTA, JOSÉ DA SILVA, Direito commercial maritimo, Rio de Janeiro, Jornal do Commercio, 1899.

COSTA, Philomeno Joaquim da, Aspectos das sociedades por ações, in Revista da Faculdade de Direito da Universidade de São Paulo n. ${ }^{\circ}$ 72, 1977, pp. 4 e ss.

COSTA, Philomeno Joaquim da, Comentário a jurisprudência do caso Petroplastic, in RDM 70, 1988, pp. 82-93.

COSTA, Philomeno Joaquim da, O pensamento de Tullio Ascarelli sobre aspectos das sociedades por ações, in RDM 38, 1980, pp. 37-46.

COSTA, Philomeno Joaquim da, Parecer (relativo ao caso Petroplastic), in Revista Forense 298, 1987, pp. 140-151.

COTTINO, Gastone, Le convenzioni di voto nelle società comercialli, Milano, Giuffrè, 1958. 
COTTINO, Gastone, Contrattualismo e istituzionalismo (Variazioni sul tema da uno spunto di Giorgio Oppo), in Rivista delle Società, n. ${ }^{\circ}$, julho - agosto, 2005, pp. 693-709.

COURET, Alain, Cession d'actions. Échange de promesses unilatérales réciproques. Promesse synallagmatique. Vente parfaite. Note: Cession d'acions: réqualification de promesses croisées em vente parfaite, in Bulletin Joly Sociétés, Março, 2006, pp.377- 386.

COURET, Alain, Clause Léonine. Augmentation de capital. Promesse unilatérale de rachat. Prix minimum. Note: Clauses de prix dans les promesses d'achat de droits sociaux, in Bulletin Joly Sociétés, Janeiro, 2006, pp.1077- 1088.

COURET, Alain, Clause léonine. Pacte d'actionnaires. Promesse de rachat d'actions. Prix minimum. Caractère léonin (non). Note: Clause léonin dans une opération de capital-investissement, in Bulletin Joly Sociétés, Janeiro, 2001, pp.47-50.

COURET, Alain, Le droit des sociétés et le besoin de sécurité à l'aube du troisiéme millénaire, in Revue des Sociétés n. ${ }^{\circ}$, janeiro - março, 2000, pp. 89-99.

CUNHA PEIXOTO, Carlos Fulgêncio da, Sociedades por ações, 5 vol., São Paulo, Saraiva, 1972-73.

CUSHING, Harry A., Voting Trusts - A Chapter in Modern Corporate History, New York, MacMillan, 1927.

D'ALESSANDRO, Floriano, La seconda direttiva e la parità di trattamento degli azionisti, in Rivista delle Società, janeiro-fevereiro, 1987, p. 113.

DA Veiga JUNIOR, Didimo Agapito, As sociedades anonymas (Lei $n$. 3.150, de 4 de novembro de 1882 - Commentario), Rio de Janeiro, Nacional, 1888 .

DAGOT, Michel, Le pacte de préférence, Paris, Litec, 1988.

DAIGRE, Jean-Jacques e SENTILLES-DUPONT, Monique, Pactes d'actionnaires, Joly, Paris, 1995.

DAIGRE, Jean-Jacques, Pacte d'actionnaires et capital risque - Typologie et appréciation, in Bulletin Joly Sociétés, n. ${ }^{\circ} 2$, 1993, p. 157-158.

DAIGRE, Jean Jacques, Pacte d'Actionnaires. Rachat. Préemption. Augmentation de capital. Minorité de blocage. Incidence. De l'interpretation et de la sanction des pactes d'actionnaires, in Bulletin Joly Sociétés, abril, 1999, pp.482- 488. 
DALLARI, Adilson Abreu, Sociedade de economia mista - Nulidade de acordo de acionistas que importa em mudança de seu acionista controlador, in RDA, n. ${ }^{\circ} 222,2000$, pp. 348-57.

DALLARI, Adilson Abreu, Sociedade de economia mista - Sócio estratégico - Acordo de acionistas (Parecer), in RDA, n. ${ }^{\circ} 221$, pp. 379-400.

DALMARTELLO, Arturo, I rapporti giuridici interni nelle società commerciali, Milano, Giuffrè, 1937.

DAlMARTEllo, Arturo, I Contratti delle Imprese Commerciali, Padova, Cedam, 1958.

DALMARTELlo, Arturo, Azioni privilegiate e partecipazione alle perdite, in Giurisprudenza Commerciale, n. ${ }^{\circ}$ 1, 1979, pp. 369 e ss.

DE NOVA, Giorgio, Nuovi contratti, Torino, UTET, 1990.

DOHM, Jürgen, Les accords sur l'exercice du droit de vote de l'actionnaire, Geneve, Librairie de l'Université Georg \& Cie S.A, 1971.

DOM, Jean-Philippe, Les montages en droit des sociétés, Paris, Joly, 1998.

DOM, Jean Philippe, Clauses Léonines. Vente ferme. Paiement du prix reporté dans le temps. Transfert de propriété échelonné. Caractère léonin (non). Note: absence de caractère léonin d'une vente de droits sociaux avec paiement du prix et transfert de propriété des actions échelonnes dans le temps, in Bulletin Joly Sociétés, dezembro, 2000, pp.1142- 1148 .

DONDERO, Bruno, Statuts de SAS et pactes extra-statutaires: questions et confrontations, in Bulletin Joly Sociétés, março, 2008, pp.245- 252.

DRAETTA, Ugo, Brevi note sulla lege applicabile ai patti parasociali, in Rivista di Diritto Internazionale Privato e Processuale, n. ${ }^{\circ} 40,2,2004$, pp. $565-74$.

EASTERBROOK, Frank. H. e FISCHEL, Daniel. R., The Economic Structure of Corporate Law, Cambridge, Harvard Univesity, 1991.

EIZIRIK, Nelson, Questões de direito societário e mercado de capitais, Rio de Janeiro, Forense, 1987.

EIZIRIK, Nelson, Sociedades anônimas: jurisprudência, Rio de Janeiro, Renovar, 1996.

EIZIRIK, Nelson, Acordo de acionistas - Arquivamento na sede social Vinculação dos administradores de sociedade controlada (Parecer), in RDM 129, 2003, pp. 45-53. 
ESPINA, Daniel, La autonomía privada en las sociedades de capital: principios configuradores y teoría general, Madrid, Marcial Pons, 2003.

ESPINOLA, Eduardo, Sociedades anonymas - alienação do voto de acionistas - Inadmissibilidade, in Revista de Direito Civil, Commercial e Criminal, LXXXVII, Fasc. 1, janeiro, 1928, pp. 46083.

FAGES, Bertrand, Etendue d'un droit de préemption. Rupture de pourparlers de fusion. Note: Triple hommage à la liberté contractuelle. Le droit de préemption s'interprète restrictivement. La fraude ne se présume pas. La rupture de pourparlers de fusion n'est pas nécessairemente fautive, in Bulletin Joly Sociétés, junho, 2008, pp.311- 316 .

FARENGA, Luigi, I contratti parasociali, Milano, Giuffrè, 1987.

FARIA, Antonio Bento de, Direito comercial, Rio de Janeiro, Coelho Branco, 1947.

FAVARO, Thierry, Regards civilistes sur le contrat de société, in Revue des Sociétés, n. ${ }^{\circ}$ 1, janeiro - março, 2008, pp. 53-79.

FAVERO, Marc, La standardisation contractuelle, enjeu de pouvoir entre les parties et de compétition entre systèmes juridiques, in Revue Trimestrielle de Droit Commercial et de Droit Économique, n. ${ }^{\circ}$ 3, junho - setembro, 2003, pp. 429-48.

FELSANI, Fabiana Massa, Clausole atipiche e diversa qualificazione della società, in Rivista del Diritto Commerciale e del Diritto Generale delle Obbligazioni, n. ${ }^{\circ}$ 9/12, setembro - dezembro, 1989, pp. 615-50.

FERNANDES, Wanderley (coord.), Fundamentos e princípios dos contratos empresariais, São Paulo, Saraiva, 2007.

FERREIRA, Waldemar, Tratado de direito comercial, Vol. 8, São Paulo, Saraiva,1960-2.

FERREIRA, Waldemar, Curso de direito commercial, Vol. 2., São Paulo, Salles Oliveira, 1927.

FERREIRA, Waldemar, Instituições de direito comercial, Vol. 1, Rio de Janeiro, Freitas Bastos, 1944.

FERRI JUNIOR, Giuseppe, Organizzazione societaria e autonomia statutaria, in Rivista del Diritto Commerciale e del Diritto Generale delle Obbligazioni, n. ${ }^{\circ}$ 5, maio - agosto, 2001, pp. 227-42.

FERRI, Giuseppe, Partecipazione agli utili, in Enciclopedia del Diritto, n. ${ }^{\circ}$ 32, 1982. 
FERRO-LUZZI, Paolo, I contratti associativi, Milano, Giuffrè, 1976.

FIGUEIREDO, Lucia Valle, Privatização parcial da CEMIG - Acordo de acionistas - Impossibilidade de o controle societário ser compartilhado entre o Estado de Minas Gerais e o acionista estrangeiro minoritário (Parecer), in RDM 118, 2000, pp. 219-35.

FLEISCHER, Holger, Gesellschaftrecht, in Rechtswissenschaft und Rechtsliteratur im 20. Jahrhundert, Dietmar Willoweit (org), München, Beck, 2007, pp. 485-502.

FLEISCHER, Holger, Gesetz und Vertrag als alternative Problemlösungsmodelle im Gesellschaftsrecht, in Zeitschrift für das gesamte Handelsrecht und Wirtschaftsrecht, n. ${ }^{\circ}$ 6, dezembro, 2004, pp. 673-707.

FORGIONI, Paula A., Teoria geral dos contratos empresariais, São Paulo, RT, 2009.

FORGIONI, Paula A., A evolução do Direito Comercial brasileiro: da mercancia ao mercado, São Paulo, RT, 2009.

FORGIONI, Paula A., Contrato de distribuição, São Paulo, RT, 2005.

FORGIONI, Paula A., Os fundamentos do antitruste, $3^{\mathrm{a}}$ ed., São Paulo, RT, 2008 .

FORGIONI, Paula A., A interpretação dos negócios empresariais e o novo Código Civil brasileiro, in RDM 130, 2003, pp. 7-38.

FORGIONI, Paula A., A unicidade do regramento jurídico das sociedades limitadas e o art. 1.053 do CC: Usos e costumes, regência supletiva. in RDM 147, 2007, pp. 7-12.

FORGIONI, Paula A., Análise econômica do Direito (AED): paranóia ou mistificação?, in RDM 139, 2005, pp. 244-40.

FORGIONI, Paula A., Apontamentos sobre algumas regras de interpretação dos contratos comerciais: Pothier, Cairu e Código Comercial de 1850, in RDM 141, 2006, pp. 31-40.

FORGIONI, Paula A. e MESSINA, Paulo de Lorenzo, Sociedade por ações: jurisprudência, casos e comentários, São Paulo, RT, 1999.

FORGIONI, Paula A. e GRAU, Eros Roberto, O Estado, A Empresa, O Contrato, São Paulo, Malheiros, 2005.

FORGIONI, Paula A.e OCHMAN, Renato e, A 'importação' de cláusulas e os riscos frente ao direito brasileiro, in Valor Econômico, 07 nov. 2002. 
FORTUNATO, Sabino, Il diritto societario in prospettiva europea: princípi generali e ricadute comunitarie, in Rivista delle Società, n. ${ }^{\circ} 3$, maio - junho, 1994, pp. 426-40.

FOYER, Jean, Quel droit des sociétés dans le millénaire qui s'avance?, in Revue des Sociétés, n.o 1, janeiro - março, 2000, pp. 101-108.

FRANÇA, Erasmo Valladão Azevedo e Novaes (org.), Direito societário contemporâneo I, São Paulo, Quartier Latin, 2009.

FRANÇA, Erasmo Valladão Azevedo e Novaes, Conflito de interesses nas assembléias de S.A., São Paulo, Malheiros, 1993.

FRANÇA, Erasmo Valladão Azevedo e Novaes, Invalidade das deliberações de assembléia das S.A., São Paulo, Malheiros, 1999.

FRANÇA, Erasmo Valladão Azevedo e Novaes, Temas de direito societário, falimentar e teoria da empresa, São Paulo, Malheiros, 2009.

FRANZONI, Massimo, Vecchi e nuovi diritti nella società che cambia, in Contratto e Impresa, n. ${ }^{o}$ 2, maio - agosto, 2003, pp. 565-90.

FREYRIA, Charles, Étude de la jurisprudence sur les conventions portant atteinte a la liberté du vote dans les sociétés, in Revue trimestrielle de droit commercial, n. ${ }^{\circ}$ IV, 1951, pp. 419-437.

GALGANO, Francesco, Contrattualismo o no per le società di capitali, in Contratto e Impresa, 1998, pp. 1 e ss.

GALGANO, Francesco, La società e lo schermo giuridico della personalità giuridica, in Giurisprudenza Commerciale, n. ${ }^{\circ}$ 1, 1983, pp. 5-16.

GALGANO, Francesco, La clausola di gradimento, i patti parasociali e la categoria dell'inefficacia del contratto, in Contratto e Impresa, n. ${ }^{\circ} 13$, 3, 1997, pp. 895-901.

GALVÃO TELES, Fernando, União de contratos e contratos para-sociais, in Revista da Ordem dos Advogados Portugueses, janeiro/junho, 1951, pp. 37-103.

GAMBINO, Agostino, Azioni privilegiate e partecipazione alle perdite, in Giurisprudenza Commerciale, n. ${ }^{\circ} 1,1979$.

GARRIGUES, Joaquim, Sindicatos de Accionistas, in Revista de Derecho Mercantil, n. ${ }^{\circ}$ 55, Janeiro - Março, 1955, pp. 91-107.

GAUDEMET, Antoine, La portée des pactes de préférence ou de préemption sur des titres de société, in Revue des sociétés, n. ${ }^{\circ} 3$, março, 2011, pp. 139-148. 
GERMAIN, Michel, La renonciation aux droits propres des associés: illustrations, in Mélanges en l'honneur du Pr. F. Terré, L'avenir du droit, Paris, Dalloz, 1999, pp. 401-413.

GIORDANO, Domenico, Le limitazioni all'autonomia privata nelle società di capitali, Milano, Giuffrè, 2006.

GIRÓN TENA, J., Derecho de sociedades - Parte general. Sociedades colectivas y comanditarias, Tomo I, Madrid, 1976.

GODON, Laurent, Les obligations des associés, Paris, Economica, 1999.

GOFFAUX-CALLEBAUT, Geraldine, Du contrat en droit des sociétés: essai sur le contrat instrument d'adaptation $d u$ droit des sociétés, Paris, L'Harmattan, 2008.

GOMES, Orlando, Contratos, 20 a ed, Rio, Forense, 2000.

GOMES, Orlando, Transformações gerais no direito das obrigações. São Paulo, 2a ed., aumentada, São Paulo, RT, 1980.

GONÇALVES, Alfredo de Assis, Acordo de acionistas e criação de ações preferenciais de classe menos favorecida, in Revista da Faculdade de Direito da UFPR, n. ${ }^{\circ}$ 30, 1998, pp. 121-39.

GOUNOT, Emmanuel, Le principe de l'autonomie de la volonté en droit privé, contribution à l'étude critique de l'individualisme juridique, Paris, 1912.

GRAU, Eros Roberto e FORGIONI, Paula A., O Estado, a Empresa e o Contrato, São Paulo, Malheiros, 2005.

GRAU, Eros Roberto, Ensaio e discurso sobre a interpretação/aplicação do direito, $3^{\mathrm{a}}$ ed., São Paulo, Malheiros, 2005.

GRAU, Eros Roberto, O direito posto e o direito pressuposto, São Paulo, Malheiros, 2000.

GRAU, Eros Roberto, Sociedade de economia mista - CEMIG Transferência do seu controle acionário mediante a formalização de acordo de acionistas - Nulidade do acordo de acionistas, in Boletim de direito administrativo n. ${ }^{\circ}$ 10, 1999, pp. 669-76.

GRAU, Eros Roberto, Sociedade de economia mista - Nulidade de acordo de acionistas que importa em mudança de seu acionista controlador (Parecer), in RDA n. ${ }^{\circ} 222$, 2000, pp. 348-57.

GUERREIRO, José Alexandre Tavares, Execução específica do acordo de acionistas, in RDM 41, 1981, pp. 40-68.

GUERREIRO, José Alexandre Tavares, Aquisição de quotas pela própria sociedade, in RDM 36, 1979, pp. 49-57. 
GUERREIRO, José Alexandre Tavares, Direito das minorias na sociedade anônima, in RDM 63, 1986, pp. 106-111.

GUERREIRO, José Alexandre Tavares, Evolução e perspectivas das sociedades por quotas de responsabilidade limitada, in AASP, São Paulo.

GUERREIRO, José Alexandre Tavares, Sobre a interpretação do objeto social, in RDM 54, 1984, p. 67-72.

GUERREIRO, José Alexandre Tavares, in ARnoldo WAld (coord.), O direito na década de 80:estudos juridicos em homenagem a Hely Lopes Meirelles, São Paulo, RT, 1985, pp. 143-49

GUERREIRO, José Alexandre Tavares, Sobre a opção de compra de ações, in RDM 39, 1980, pp. 226-229.

GUERREIRO, José Alexandre Tavares, Sociedade anônima: poder $e$ dominação, in RDM 53, 1984, pp. 72-80.

GUERREIRO, José Alexandre Tavares, Sociologia do poder na sociedade anônima, in RDM 77, 1990, pp. 50-56

GUERREIRO, José Alexandre Tavares e TEIXEIRA, Egberto Lacerda Das sociedades anônimas no direito brasileiro, 2 vol., São Paulo, Bushatsky, 1979.

GUGLIELMETTI, Gianmario, Le azioni postergate nelle perdite, in Giurisprudenza commerciale, n. ${ }^{\circ} 2,1982$, pp. 844 e ss.

GUGLIELMUCCI, Lino, Lo smobilizzo delle partecipazioni nei patti parasociali delle finanziarie regionali private, in Rivista delle Società, 1980, pp. 1196 e ss.

GUIMARÃES, Ruy Carneiro, Sociedade por ações: notas de doutrina e jurisprudência, 3 vol., Rio de Janeiro, Forense, 1960.

GUMMERT, Hans e WEIPERT, Lutz (org.), Münchener Handbuch des Gesellschaftsrechts, B and 1, München, Beck, 2009.

GUYON, Yves, La fraternité dans le droit des sociétés, in Revue des Sociétés, 1989, p. 439-448.

GUYON, Yves, Les sociétés: aménagements statutaires et conventions entre associés, in Traité des Contrats, Jacques Ghestin (coord.), $5^{\text {a }}$ ed., Paris, LGDJ, 2000.

GUYON, Yves, La société anonyme, une démocratie parfaite!, in Melanges Gavalda, Paris, Dalloz, 2001, pp. 133-146.

HALEMBECK, Luiz Fernando Amaral, Arranjos societários usuais em negócios de Internet, in LUÍs EDUARDO SCHOUERI, (org.), Internet: o direito na era virtual, Rio de Janeiro, Forense, 2001, pp. 9-15. 
HAMEL, Joseph e LAGARDE, Gaston, Traité de droit commercial, 2 vol., Paris, Dalloz, 1954.

HANSMANN, Henry e KRAAKMAN, Reinier, The end of history for corporate law, International center for finance working paper,.$^{\circ}{ }^{0} 0$ 09, 2000, disponível em: http://papers.ssrn.com/paper.taf?abstract_id=204528.

HANSMANN, Henry e KRAAKMAN, Reinier, The essential role of organizational law, John M. Olin Center for law, Economics, and Business discussion paper, n. ${ }^{\circ}$ 284, 2000, disponível em: http://papers.ssrn.com/paper.taf?abstract_id=229956.

HANSMANN, Henry e KRAAKMAN, Reinier, What is Corporate Law?, Center for law, economics and public policy research paper, n. ${ }^{\circ} 300$, 2004, disponível em: http://ssrn.com/abstract=568623.

HANSMANN, Henry, Corporation and Contract, Law Working Paper, n. ${ }^{\circ} .66 / 2006$, março, 2006, European Corporate Governance Institute, disponível em: http://ssrn.com/abstract=892830.

HART, Oliver, Contractual freedom in corporate law, articles and comments: an economist's perspective on the theory of the firm, in Columbia Law Review 89, 1989, pp. 1757 e ss.

HÉMARD, Joseph, Théorie et pratique des nullités de sociétés et des sociétés de fait, Paris, Sirey, 1926.

HENZE, Hartwig, TIMM, Wolfram e WESTERMANN, Peter (org.), RSWForum 8 - Gesellschaftsrecht 1995, Köln, Kommunikationsforum $\mathrm{GmbH}$, sd.

HEY, Felix Christopher, Freie Gestaltung in Gesellschaftsverträgen und ihre Schranken, München, Beck, 2004.

HISCHMANN, Christoph, Neue Gestaltungsfreiheit im französischen Gesellschaftsrecht: Die Société par actions simplifié (SAS), Berlin, Duncker \& Humblot, 2001.

HOFFMAN-BECKING, Michael, Der Einfluß schuldrechtlicher Gesellschaftervereinbarungen auf die Rechtsbeziehungen in der Kapitalgesellschaft, in ZGR 3, 1994, pp. 442-64.

HOPT, Klaus J., Company law modernization: transatlantic perspectives in Rivista delle Società, n. ${ }^{\circ}$ 5-6, setembro - dezembro, 2006, pp. 90634.

HOPT, Klaus J., Comparative Company Law, Law Working Paper, n.77/2006, European Corporate Governance Institute, dezembro, 2006, disponível em: http://ssrn.com/abstract=980981. 
HOPT, Klaus J., Droit comparé des sociétés - Quelques réflexions sur l'actualité et les évolutions comparées du droit allemand et du droit français des sociétés, in Revue des Societés, n. 2, abril - junho, 2009, pp. 309-22.

HOPT, Klaus J., WIEDEMANN, Herbert (org.), Aktiengesetz Großkommentar, Berlin, De Gruyter Recht, sd.

HUCK, Hermes Marcelo, Pactos societários leoninos, in RT 760, 1999, pp. 64-73.

HÜFFER, Uwe, Aktiengesetz, Band 53, München, Beck, 2010.

IRTI, Natalino, Teoria generale del diritto e problema del mercato, in Rivista di Diritto Civile, 1999, pp. 1-29.

IRUJO, José Miguel Embid, El presente incierto del derecho de sociedades, in Revista de Derecho Mercantil, no 271, janeiro - março, 2009, pp. 453-482.

IRUJO, José Miguel Embid, Necrológica: Yves Guyon (1934-2005), in Revista de Derecho Mercantil, $\mathrm{n}^{\circ}$ 257, julho - setembro, 2005, pp. $1675-1677$.

JAEGER, Pier Giusto e BONELLI, Franco (coord.), Sindacati di voto $e$ sindacati di blocco, Milano, Giuffrè, 1993.

JAEGER, Pier Giusto e DENOZZA, Francesco, Appunti di diritto commerciale, Milano, Giuffrè, 1997.

JAEGER, Pier Giusto, Profili dell'armonizzazione del diritto societario, in Rivista Trimmestrale di Diritto e Procedura Civile, n. ${ }^{\circ} 2$, 1994, pp. 681 e ss.

JOUSSEN, Edgar, Gesellschafterabsprachen neben Satzung und Gesellschaftsvertrag, Köln, Otto Schmidt, 1995.

JUNQUEIRA DE AZEVEDO, Antonio, Negócio Jurídico, Existência, Validade e Eficácia, 4a Ed., São Paulo, Saraiva, 2002.

JUNQUEIRA DE AZEVEDO, Antonio, Estudos e pareceres de direito privado, São Paulo, Saraiva, 2004.

JUNQUEIRA DE AZEVEDO, Antonio, Novos estudos e pareceres de direito privado, São Paulo, Saraiva, 2009.

KENDÉRIAN, Fabien, La contribution aux pertes sociales, in Revue des Sociétés, n. ${ }^{\circ}$, outubro - dezembro, 2002, pp. 617-51.

KÖHLER, Cláudio, Nebenabreden im GmbH-und Aktienrecht - Zulässigkeit und Wirkung, Frankfurt am Main, Peter Lang, 1992. 
KÖNIG, Wolfgang, Der satzungsergänzende Nebenvertrag: eine rechtvergleichende Untersuchung zum außerstatutarischen Gesellschaftsorganisationsrecht nach deutschem, frazösischem und schweizerischem Recht, Baden-Baden, Nomos, 1996.

KRAAKMAN, Reinier $\mathrm{R}$. et al., The anatomy of corporate law: a comparative and functional approach, New York, Oxford, 2004.

LA ROSA, Antonio Pavone, La “trasparenza” dei patti parasociali nelle società per azioni "aperte”, in Giurisprudenza Commerciale, n. XXXIV, 2007, pp.549-554.

LACERDA, Galeno, Sociedade anônima - Realização paulatina do capital - Acordo de acionistas, in RT 704, 1994, pp. 21-35.

LAMY FILHO, Alfredo e BULHÕES PEDREIRA, José Luiz, A Lei das S.A., Rio de Janeiro, Renovar, 1992.

LAMY FILHO, Alfredo e BULHÕES PEDREIRA, José Luiz, Direito das Companhias, Rio, Forense, 2009.

LAMY FILHO, Alfredo, A reforma nas S/A, in RDM 7, 1972, p. 123-158.

LAMY FILHO, Alfredo, Considerações sobre a elaboração da lei de S.A e de sua necessária atualização, in RDM 104, 1996, pp. 86-94.

LAMY FILHO, Alfredo, Temas de S.A.: exposições, pareceres, Rio de Janeiro, Renovar, 2007.

LARENZ, Karl, Metodologia da ciência do direito, $3^{\mathrm{a}}$ ed., Lisboa, Calouste Gulbenkian, 1997.

LARRIEU, Peggy, L'interprétation des pactes extra-statutaires, in Revue des Sociétés, n. ${ }^{\circ}$ 4, 2007, pp. 697-712.

LE BRAS, William, Les promesses de cession de droits sociaux et la prohibition des clauses léonines, in Buletin Joly, 1986, pp. 587-590.

LE CANNU, Paul, Pacte d'Actionnaires. Pacte de préférence. Convention de parrainage. Promesse de cession d'actions. Collusion frauduleuse. Nullité. Note: Nullité d'une cession de droits sociaux conclue em violation d'un pacte de préférence, in Bulletin Joly Sociétés, abril, 2004, pp.544- 551.

LE CANNU, Paul, Pacte d'actionnaires. Résolution. Note:Dénaturation d'um pacte d'actionnaires, in Bulletin Joly Sociétés, junho, 2005, pp.760- 763 .

LE NABASQUE, Hervé, Pacte d'Actionnaires. RES. Égalité entre actionnaires. Exécution forcée du pacte. Note: Exécution forcée en nature d'un pacte d'actionnaires. in Bulletin Joly Sociétés, abril, 2002, pp.509- 515 . 
LE NABASQUE, Hervé, Pacte de préférence. Sanction. Note:Sanction de la violation d'un pacte de préférence: la substitution peut désormais être ordonée par le juge, in Bulletin Joly Sociétés, agosto, 2006, pp.1072-1079.

LEÃES, Luis Gastão Paes de Barros, Do direito do acionista ao dividendo, São Paulo, Obelisco, 1969.

LEÃES, Luis Gastão Paes de Barros, Estudos e pareceres sobre sociedades anônimas, São Paulo, RT, 1989.

LEÃES, Luis Gastão Paes de Barros, Pactos Parassociais. Natureza jurídica - Execução específica - Opção de recompra de participação acionária e inexistência de infringência dos arts. 288 do Código Comercial e 1372 do CC por não configurar pacto leonino, in RT, 601, 1985, pp. 40-49.

LEÃES, Luis Gastão Paes de Barros, Pareceres, 2 vol., São Paulo, Singular, 2004.

LEÃES, Luiz Gastão Paes de Barros, Comentários à Lei das Sociedades Anônimas, Vol. 2, São Paulo, Saraiva, 1980.

LEAL, Ana Filipa, Algumas notas sobre a parassocialidade no direito português, in Revista de Direito das Sociedades, n. ${ }^{\circ}$ 1, 2009, pp. 135183.

LEHMANN, Heinrich, Gesellschaftsrecht, $3^{\mathrm{a}}$ ed., Berlin, Franz Vahlen $\mathrm{GmbH}, 1970$.

LISBOA, José da Silva, (Visconde de Cairu), Principios de direito mercantil e leis de marinha, $6^{\mathrm{a}}$ ed., Rio de Janeiro, Acadêmica, 1874.

LOBO, Jorge et al., A reforma da lei das sociedades anônimas, Rio de Janeiro, Forense, 2002.

LOMBARDI, Giuseppe, I patti parasociali nelle società non quotate e la riforma del diritto societario, in Studi in onore di Piero Schlesinger, Tomo IV, Milano, Giuffré, 2004, pp. 2775-2798.

LÜBBERT, Hartmut, Abstimmungsvereinbarungen in den Aktien- um GmbH-Rechten der EWG-Staaten, der Schweiz und Großbritanniens, Baden-Baden, Nomos, 1971.

LUCAS, François Xavier, Clauses léonines. Promesse d'achat d'actions. Bénéficiaire bailleur de fonds. Service financier. Note:Retour sur le caractère (non) léonin des promesses d'achat d'actions à prix minimum garanti, in Bulletin Joly Sociétés, Junho, 2009, pp.583- 587.

LUCAS, François-Xavier, Pacte d'actionnaires. Droit de préférence. Mise em oeuvre du droit de préférence à l'occasion d'une cession globale 
de diverses participations. Violation du pacte. Collusion entre le cédant et le cessionaire. Sanction. Annulation de la cession. Note: variations autour d'un pacte d'actionaires instituant un droit de préférence, in Bulletin Joly Sociétés, novembro, 2007, pp.1203-1211.

LUCAS, François-Xavier, Pacte d'actionnaires. Nullité (non). Droit de rpéférence. Clause d'offre alternative. Éxecution forcée du pacte. Note:Validité et efficacité d'unpacte d'actionnaires in Bulletin Joly Sociétés, janeiro, 2007, pp.72-84.

LUTTER, Marcus e WIEDEMANN, Herbert (org), Gestaltungsfreiheit im Gesellschaftsrecht. Deutschland, Europa und USA. 11. ZGRSymposium "25 Jahre ZGR”, Berlin, Walter de Gruyer, 1998.

MACHADO, Sylvio MARCONDES, Problemas de direito mercantil, São Paulo, Max Limonad, 1970.

MACHADO, Sylvio Marcondes, Ensaio sobre a sociedade de responsabilidade limitada, Tese de Livre-Docência, Faculdade de Direito da Universidade de São Paulo, São Paulo, 1940.

MAGAlHÃES, Descartes de, Curso de direito comercial, Vol. 1, $1^{\mathrm{a}}$ ed., Salvador, Bahiana, 1919.

MARASÀ, Giorgio, Le società: società in generale, in Trattato di diritto privato a cura di Giovanni Iudica e Paolo Zatti, $2^{a}$ ed., Milano, Giuffrè, 2000.

MARINO, Francisco Paulo de Crescenzo, Contratos Coligados no Direito Brasileiro, São Paulo, Saraiva, 2009.

MARINO, Francisco Paulo de Crescenzo, Interpretação do Negócio Jurídico, São Paulo, Saraiva, 2011, p. 65.

MARTINS, Fran, Comentários à lei das sociedades anônimas (Lei 6.404 de 15 de dezembro de 1976), 3 vol., Rio de Janeiro, Forense, 1977-79.

MARTINS, Fran, Curso de direito comercial, Ceará, Universitária, 1957.

MARTINS, Fran, Sociedade por quotas no direito estrangeiro e brasileiro, Rio de Janeiro, Forense, 1960.

MARTINS, Fran, Acordo de acionistas: contrato plurilateral, in Revista da Faculdade de Direito da UFC 29, n. ${ }^{\circ}$ 1, 1988, pp. 59-71.

MARTINS-COSTA, Judith, Da Boa-fé no Direito Privado, São Paulo, RT, 2000

MARTINS-COSTA, Judith, Os avatares do Abuso do Direito e o rumo indicado pela Boa-Fé, Trabalho apresentado ao Congresso Internacional de Direito Civil-Constituconal da Cidade do Rio de Janeiro - 21-23 de setembro de 2006. 
MASSART, Thibaut, Cession d'actions. Droit de préemption. Conditions d'exercice. Note: De la distinction entre le droit de priorité et le droit de preemption, in Bulletin Joly Sociétés, outubro, 2008, pp.779-784

MASSART, Thibaut, Cession d'actions. Promesse unilatérale d'achat. Prix Minimum. Caractère léonin (non). Clause d'intérêt. Faculté de substitution. Note: Vive le capital-risque sans risque, in Bulletin Joly Sociétés, abril, 2002, pp.499- 509.

MAZZAMUTO, Salvatore, I patti parasociali: una prima tipizzazione legislativa, in Diritto e Processo, 2005, pp. 99-117.

MCNEIL, Ian, The relational theory of contract: Selected Works of Ian Macneil, London, Sweet \& Maxwell, 2001.

MENDES, Octavio, Curso de direito commercial terrestre, São Paulo, Saraiva, 1930.

MENEZES, Mauricio Moreira Mendonça de, Resolução de acordo de acionistas com base na quebra da affectio societatis (comentário ao acórdão do Superior Tribunal de Justiça no Recurso Especial $n$. 388.423-RS), in RTDC, n. ${ }^{\circ} 23,2005$, pp. 141-67.

MENEZES CORDEIRO, António, Manual de direito das sociedades, vol. 1, $2^{a}$ ed., Coimbra, Almedina, 2007.

MENEZES CORDEIRO, António, Da Boa-fé do Direito Civil, , Coimbra, Almedina, 2011.

MENEZES CORDEIRO, António, Acordos parassociais, in Revista da Ordem dos Advogados Portugueses, abril, 2001, pp. 529-542.

MENEZES CORDEIRO, António, A lealdade no direito de sociedades, in Revista da Ordem dos Advogados, dez-2006 (sem identificação de páginas).

MERTENS, Hans-Joachim, Satzungs- und Organisationsautonomie im Aktien-und Konzernrecht, in ZGR 3, 1994, pp. 426-441.

MESQUITA, José Ignácio Botelho de, Execução específica de Direito de Preferência Originado de Acordo de Acionistas in AAVV., Temas de Direito Societário e Empresarial Contemporâneos - Liber Amicorum Prof. Dr. Erasmo Valladão Azevedo e Novaes França, São Paulo,Malheiros, 2011, pp. 836-848.

MESSAI-BAHRI, Soraya, Pacte d'actionnaires. Clause d'exclusivité. Violation par l'ancien président. Concurrence déloyale commise avec la complicité d'une société tierce. Responsabilité délictuelle du dirigeant actionnaire et de la société tierce à l'égard de la société victime de la concurrence déloyale. Note: L'opposabilité du pacte 
d'actionnaires par le tiers, in Bulletin Joly Sociétés, junho, 2008, pp.493 ss.

MESSINA, Paulo de Lorenzo e FORGIONI, Paula A., Sociedade por ações: jurisprudência, casos e comentários, São Paulo, RT, 1999.

MESSINEO, Francesco, Studi di diritto delle società, Milano, Giuffré, 1949.

MESSINEO, Francesco, La clausola di gradimento all'alienazione e diritti inerenti alla qualità di socio, in Nuovi studi di diritto delle società, Milano, Giuffrè, 1966, pp. 55-66.

MESSINEO, Francesco, Sui requisiti di validità della clausola di gradimento 'placet' all'alienazione delle azioni, in Nuovi studi di diritto delle società, Milano, Giuffrè, 1966, pp. 19-53.

MESTRE, Jacques, L'égalité en droit des sociétés (aspects de droit privé), in Revue des sociétés, 1989, 399-410.

MIGNOLI, Ariberto, La societá per azioni: problemi, letture, testimonianze, Milano, Giuffré, 2002.

MIGNOLI, Ariberto, Contribuição de Tullio Ascarelli à doutrina das sociedades anônimas, in RDM 38, 1980, pp. 37-46.

MIGNOLI, Ariberto, La società per azioni oggi. Problemi e confliti, in Rivista delle Società, 1990.

MINERVINI, Gustavo, Partecipazione a scopo di finanziamento e patto leonino, in Contratto e Impresa, 1988, pp. 771 e ss.

MONIZ, Salvador, Sociedades anonymas, Rio de Janeiro, Francisco Alves \& Cia, 1914.

MOREIRA, Raul Justino Ribeiro, Acordo de acionistas, in Revista de ciência política, no $31,2,1988$, pp. 87-98.

MORTIER, Renaud, Rachat d'actions et actions rachetables, in Revue des Sociétés, n. ${ }^{\circ} 3$, julho - setembro, 2004, pp. 639-58.

MOURY, Jacques, Qualification du pacte d'actionnaires stipulant qu'il s'appliquera aussi longtemps que les parties demeureront ensemble actionnaires - Note sous Cour de cassation (com.) 6 novembre 2007, Société CGTH c/ Société CMP, in Revue des Sociétés, n. ${ }^{\circ} 1$, janeiro março, 2008, pp. 89-95.

MOUSSERON, Pierre, Cession d'actions. Promesses croisées. Promesse synallagmatique de vente. Date de transfert de propriété. Date de fixation du prix. Note: les arcanes de la tecnhique des promesses croisées, in Bulletin Joly Sociétés, janeiro, 2008, pp.687-690.-43. 
MOUSSERON, Pierre, Conventions de garantie et pactes d'actionnaires, in Bulletin Joly Sociétés, outubro, 2009, pp.924-929.

MOYANO, María Jesus Peñas, Las prestaciones accesorias en la sociedad anónima, Pamplona, Aranzadi Editorial, 1996.

MUSSI, Luiz Daniel Haj, Acordo de acionistas na sociedade de economia mista: comentários a acrodão do Superior Tribunal de Justiça, RDPE, 2005, pp. 239-52.

NOACK, Ulrich, Gesellschaftervereinbarungen bei Kapitalgesellschaften, Tübingen, J.C.B. Mohr (Paul Siebeck), sd.

OCHMAN, Renato e FORGIONI, Paula A., A 'importação' de cláusulas e os riscos frente ao direito brasileiro, in Valor Econômico, 07 nov. 2002 .

OLIVEIRA, Brasilio Augusto Machado de, (o Barão Brasilio Machado), $O$ Codigo Commercial do Brasil em sua formação histórica, São Paulo, Salles, 1910.

OPPO, Giorgio, Contratti parasociali, Milano, Vallardi, 1942

OPPO, Giorgio, Le convenzioni parasociali tra diritto delle obligazioni e diritto delle società, in Rivista di Diritto Civile, 1987, pp. 517-30.

OPPO, Giorgio, Iguaglianza e contratto nelle società per azioni, in Rivista di Diritto Civile, 1974, pp. 629 e ss.

PAIARDINI, Martina, Sui pressuposti di configurabilitá del divieto di patto leonino, in Riv. Dir. Comm., 2011.

PAILLUSSEAU, Jean, La société anonyme: technique de organisation de l'entreprise Paris, Sirey, 1967.

PAILLUSSEAU, Jean, L'enrichissement du droit et de la pratique professionnelle (un témoignage), in Le Droit de l'Entreprise dans ses relations externes à la fin du XX Siecle - Mélages em l'honneur de Claude Champaud, Paris, Dalloz, 1997.

PARENTE, Norma Jonssen, A lei de sociedades anônimas sob a ótica dos princípios constitucionais, in RDM 134, abril - junho, 2004, pp. 7276.

PARLÉANI, Gilbert, Les pactes d'actionnaires, in Revue des Sociétés, 1991, pp. 1-44.

PAVONE LA ROSA, Antonio, Brevi osservazioni in tema di limiti statutari alla circolazione delle azioni, in Rivista delle Società, n. ${ }^{\circ} 4$, julho agosto, 1997, pp. 633-48.

PAVONE LA ROSA, Antonio, Profili della tutela degli azionisti, in Rivista delle Società, 1965, pp. 72-119. 
PATROCÍNIO, Daniel Moreira do, Autotutela do acordo de acionistas: novo regime estabelecido pela Lei 10.303/2001, in RDM 135, 2004, pp. 194-205.

PEDROL, Antonio, La anónima actual y la sindicación de acciones, Madrid, Revista de Derecho Privado, 1969.

PENTEADO, Luciano Camargo, Efeitos contratuais perante terceiros, São Paulo, Quartier Latin, 2007.

PENTEADO, Mauro Rodrigues, Aumentos de capital das sociedades anônimas, São Paulo, Saraiva, 1988.

PERLINGIERI, Pietro, Interpretazione ed evoluzione dell'ordinamento, in Rivista di diritto privato, abril - junho, 2011, pp. 159-170.

PIAZZA, Gabriello, La causa mista credito-società, in Contratto e Impresa, 1987 , pp. 803 e ss.

PIAZZA, Gabriello, Patto leonino, in Enciclopedia del Diritton n. ${ }^{\circ} 32$, 1982 , pp. 526 e ss.

PINTO JÚNIOR, Mario Engler, Exclusão de acionista, in RDM 54, 1984, pp. 83-89.

PIRES, Gudesteu, Manual das sociedades anônimas, São Paulo, Freitas Bastos, 1942.

PIRES, Gudesteu, Sociedades anonymas (subsidios para a reforma da lei), Rio de Janeiro, Jornal do Commercio, 1935.

PISCITELlo, Paolo, Il diritto di exit nelle Srl "chiuse" tra 'ius conditum' e prospettive di riforma, in Studi in onore di Piero Schlesinger, Tomo IV, Milano, Giuffré, 2004, pp. 2961-2976.

POLLAUD-DULIAN, Frédéric, L'actionnaire dans les opérations de portage, in Revue des Sociétés, n. ${ }^{4}$, outubro - dezembro, 1999, pp. 765-85.

PONTES DE MIRANDA, Francisco Cavalcanti, Tratado de direito privado, Tomo L, Rio de Janeiro, Borsoi, 1954.

PONTES, Aloysio Lopes, Sociedades anônimas, $4^{\mathrm{a}}$ ed., Rio de Janeiro, Forense, 1957.

PONTI, Luca e PANELLA, Paolo, Le partecipazioni sociali ingovernabili, Milano, Giuffrè, 2006.

PORACCHIA, Didier, Clause de non concurrence. Prise de participation dans une société concurrente. Violation (non). Rupture des pourparlers. Violation de l'obligation de non-concurrence. Lien de causalité (non). Note: Interprétation d'une clause de nonconcurrence, in Bulletin Joly Sociétés, abril, 2009, pp.350- 354. 
PORACCHIA, Didier, Non-efficacité d'un pacte extrastatutaire instituant un droit de préférence - Note sous Cour d'appel de Paris (3 ch. A) 4 décembre 2007, SA Mongoual et a. c/ Montaigne Jean Goujon et a., in Revue des Sociétés, n. ${ }^{\circ}$ 2, abril - junho, 2008, pp. 330-41.

PORACCHIA, Didier, Pacte de préférence et cession d'un bouquet de participations - Note sous Cour d'appel de Paris, 1 re juillet 2008, SA Consortium de Réalisation c/ Morel, in Revue des Sociétés, n. ${ }^{\circ}$, outubro - dezembro, 2008, pp. 786-97.

POZO, Luis Fernandez del e MORO, Guillermo Herrero, Configuracion estatutaria de la clausula de fijacion de precio. Requisitos, in E1 Precio en las Clausulas Restrictivas de la Libre Transmisibilidad de Acciones o Participaciones, SD, pp. 21-65.

PRADO, Viviane Müller, Aplicação imediata da nova disciplina sobre acordo de acionistas, in RDB 17, 2002, pp. 262-8.

PRIEUR, Jean, Les PME et le capital-risque, in Bulletin Joly, outubro, 1998, p.1033-149.

PROVERBIO, Davide, I patti parasociali, Milano, Ipsoa, 2004.

PROVINCIALI, Renzo, Contratti sociali e parasociali, in Rivista Trimestrale di Diritto e Procedura Civile, 1962, pp. 1318-1335.

PUECH, Philippe e VAMPARYS, Xavier, Les clauses de sortie en bourse dans les pactes d'actionnaires, in Bulletin Joly Sociétés, março, 2008, pp.262- 263.

RAMOS, Felipe de Freitas, Responsabilidade dos signatários de acordo de voto no regime da Lei 10.303/2001, in RDM 125, 2002, pp. 114-128.

REALE, Miguel, A teoria da interpretação segundo Tullio Ascarelli, in RDM 38, 1980, pp. 75-85.

REQUIÃO, Rubens, A sociedade anônima como instituição, in RDM 18 , 1975, pp. 27-38.

REQUIÃO, Rubens, Aspectos modernos de direito comercial, 2 vol., São Paulo, Saraiva, 1980 .

REQUIÃO, Rubens, Comentários à Lei das Sociedades Anônimas, São Paulo, Saraiva, 1980 .

REQUIÃO, Rubens, Curso de direito comercial, $21^{\mathrm{a}}$ ed., São Paulo, Saraiva, 1998.

RESCIO, Giuseppe Alberto, La distinzione del sociale del parasociale (sulle c.d. clausole statutarie parasociali), in Rivista delle Società, n. ${ }^{\circ}$ 36, 2-3, 1991, pp. 596-656. 
RESCIO, Giuseppe Alberto, Sulla natura e sulla forma degli statuti societari, in Rivista delle Società, n. ${ }^{\circ}$ 50/4, julho - agosto, 2005, pp. 783-817.

RESCIO, Giuseppe Alberto, La disciplina dei patti parasociali dopo la legge delega per la riforma del diritto societario, in Rivista delle Società, n. ${ }^{\circ} 47,4,2002$, pp. 840-62.

RIBEIRO, Marcia Carla Pereira, Acordo de acionistas: um breve estudo acerca das modalidades, in Revista da Faculdade de Direito da UFPR n. ${ }^{\circ} 36,2001$, pp. 61-72.

RIPERT, Georges e ROBLOT, René, Traité de Droit Commercial - Les sociétés commerciales, $18^{\mathrm{a}}$ ed., t. 1, vol. 2, atual. por Michel Germain, Paris, LGDJ, 2002.

ROCHA, João Luiz Coelho da, Acordo de Acionistas e Acordo de Cotistas, Rio de Janeiro, Lumen Juris, 2002.

ROPPO, Vincenzo, Il contratto, Milano, Giuffrè, 2001.

ROY-BOSSI, Stéphanie, Les mécanismes de 'liquidation preferences' en droit français, in Bulletin Joly Sociétés, agosto, 2007, pp.429-439.

RUSSEL, Alfredo de Almeida, Curso de direito commercial brasileiro, Rio de Janeiro, Scientifica, 1923.

RUSSEL, Alfredo, Sociedades anonymas: theoria e pratica, Rio de Janeiro, Freitas Bastos, 1929.

SAINTOURENS, Bernard, L'an 2000 et au-delà: quelles perspectives pour le droit des sociétés?, in Revue des Sociétés, n. ${ }^{\circ}$, janeiro - março, 2000, pp. 109-13.

SAINTOURENS, Bernard, La flexibilitè du droit des sociétés, in Revue Trimestrielle de Droit Commercial et de Droit Économique, 1987, pp. 457 e ss.

SALANITRO, Niccolo, Il regime dei sindacati azionari, in Rivista delle Società, n. ${ }^{\mathrm{o}} 33,4,1988$, pp. 743-56.

SALOMÃO FILHO, Calixto, O novo direito societário, $3^{\mathrm{a}}$. ed., São Paulo, Malheiros, 1998.

SAlOMÃO FILHO, Calixto, Direito Concorrencial - as estruturas, $3^{\mathrm{a}}$ ed., São Paulo, Malheiros, 2007.

SALOMÃO FILHO, Calixto, Sociedade anônima: interesse público e privado, in RDM 127, 2002, pp. 7-20.

SALOMÃO NETO, Eduardo, A natureza contratual da relação sóciosociedade, in RDM 73, 1989, pp. 39-65. 
SALOMÃO FILHO, Calixto, Breves acenos para uma análise estruturalista do contrato, in RDM 141, 2006, pp. 7-30.

SANCHEZ, Aníbal, La accion y los derechos del accionista (art. 47 a 50 LSA) in URIA, Rodrigo, MENENZES, Aurelio y OLIVENCIA, Manuel org. Comentario al regimen legal de las sociedades mercantiles, Tomo IV, Vol. 1, Madrid, Civitas, 1994.

SANTONI, Giuseppe, Patti parasociali, Napoli, Jovene, 1985.

SANTOS, Mário Leite, Contratos parassociais e acordos de voto nas sociedades anónimas, Lisboa, Cosmos, 1996.

SANTOS, Theophilo de Azeredo, Acordo de accionistas, in Revista da Ordem dos Advogados Portugueses, vol. 1, abril 1987, pp. 181-194.

SCHILLER, Sophie, Les limites de la liberté contractuelle en droit des sociétés: les connexions radicales, Paris, LGDJ, 2002.

SCHILLER, Sophie, L'influence de la nouvelle économie sur le droit des sociétés, in Revue des Sociétés, n. ${ }^{\circ}$ 1, janeiro - março, 2001, pp. 4779.

SCHILLER, Sophie, Pactes, statuts, règlement, intérieur: quelle hiérarchie?, in Revue des sociétés, n. ${ }^{\circ}$ 6, junho, 2011, pp. 331-338.

SCHMIDT, Dominique, Les droits de la minorité dans la société anonyme, Paris, Sirey, 1970.

SCHMIDT, Karsten, Gesellschaftsrecht, 4ª ed., Köln, Heymanns, 2002.

SCHMIDT, Karsten e LUTTER, Marcus (org.), Aktiengesetz Kommentar, Band 1, Köln, Dr. Otto Schmidt, 2010.

SCHNEIDER, Jörg, Wettbewerbsverbot für Aktionäre, Frankfurt am Main, Peter Lang, sd.

SCHOUERI, Luís Eduardo (org.), Internet: o direito na era virtual, Rio de Janeiro, Forense, 2001, pp. 9-15.

SEMINO, Giorgio, Il problema della validità dei sindacati di voto, Milano, Giuffrè, 2003.

SOUZA, Herculano Inglez de, Direito commercial (prelecções professadas na Faculdade Livre de Sciencias Jurídicas e Sociaes do Rio de Janeiro e compiladas pelo bacharel Alberto Biolchini), São Paulo, Escolas Profissionaes Salesianas, 1906.

SoUZA, Herculano Inglez de Direito Commercial, São Paulo, Escolas Profissionais Salesianas, 1906.

SPADA, Paolo, Autoritá e libertá nel diritto della societá per azioni, in Rivista di Diritto Civile, 1996, pp. 703-719. 
SPADA, Paolo. La tipologia delle società tra volontà e nomenclatura, in Rivista di Diritto Civile, n. ${ }^{\circ} 2,1987$, pp. 551 e ss.

SRAFFA, Angelo, Nuove forme contrattuali, in Rivista del Diritto Commerciale, 1904, pp. 428-432.

SRAFFA, Angelo, Ancora a proposito di nuove forme contrattuali, in Rivista del Diritto Commerciale, vol. III, 1905, pp. 428-432.

SRAFFA, Angelo, Patto leonino e nullità del contratto sociale, Rivista del Diritto Commerciale, 1915, pp.956-959.

STEDMAN, Graham e JONES, Janet, Shareholders'Agreements, $3^{\mathrm{a}}$ ed, Londres, Sweet\&Maxwell, 1998.

STELZIG, Peter, Zur Treuepflicht des Aktionärs unter besonderer Berücksichtigung ihrer geschichtlichen Entwicklung, Stadtlohn, sem editora, 2000.

SURKIN, Elliot M., How do I get out of here? A discussion of exit strategies in closely-held real estate $L L C s$, in The practical real state lawyer, Maio, 2002, disponível em http://files.aliaba.org/thumbs/datastorage/lacidoirep/articles/PREL_ACFA3DB_thum b.pdf.

SZTAJN, Rachel, Contrato de sociedade e formas societárias, São Paulo, Saraiva, 1989.

SZTAJN, Rachel, Associações e sociedades, in RDM 128, 2002, pp. 15-26.

SZTAJN, Rachel e VERÇOSA, Haroldo M. Duclerc, A incompletude do contrato de sociedade, in RDM 131, 2003, pp. 7-20.

TEDESCHI, Claudia, 'Poteri di orientamento' dei soci nelle società per azioni, Milano, Giuffrè, 2005.

TEIXEIRA, Egberto Lacerda, Das sociedades por quotas de responsabilidade limitada, São Paulo, Max Limonad, 1956.

TEIXEIRA, Egberto Lacerda, O anteprojeto do código civil e as sociedades limitadas, in RDM 9, 1973, pp. 103-111.

TEIXEIRA, Egberto Lacerda, As sociedades limitadas e o projeto do novo código civil brasileiro, in RDM 55, 1984, pp. 162-169.

TEIXEIRA, Egberto Lacerda, Observações sobre estatuto atípico de sociedade anônima, in RDM 71, 1998, pp. 101-04.

TEIXEIRA, Egberto Lacerda e GUERREIRO, José Alexandre Tavares, Das sociedades anônimas no direito brasileiro, 2 vol., São Paulo, Bushatsky, 1979. 
TELLES, Fernando Galvão, União de contratos e contratos para-sociais, in Revista da Ordem dos Advogados Portugueses 1-2 (jan.-jun. 1951), pp. 37-103.

TORINO, Raffaele, Sindacati di Blocco, in I Nuovi Contratti nella Prassi Civile e Commerciale XXII Società, 2004, pp. 185-211.

TORNOVSKY, Miguel, Acordos de acionistas sobre o exercício do poder de controle. Análise das principais alterações introduzidas ao art. 118 da Lei das S/A pela Lei 10.303/2001, in RDM 127, 2002, pp. 93-106.

TRÉBULE, François-Guy, Stakeholders theory et droit des sociétés. Première partie in Bulletin Joly Sociétés, (Déc -2006), pp.1337- 1354. Deuxième partie in Bulletin Joly Sociétés, janeiro, 2007, pp. 7- 33.

TREILLE, Brigitte, Les conventions de portage, in Revue des Sociétés, n. ${ }^{\circ}$ 4, 1997, pp. 721-82.

URBAIN-PARLEANI, Isabelle, Sociétés anonymes - Pactes d'actionnaires - Clauses de sortie - Exécution forcée (oui) [CA Versailles (12 ch.) 14 octobre 2004, Peignot c/ SA Alliance Développement et Conseil, in Revue des Sociétés 2, 2005, pp. 172-73.

VALVERDE, Trajano de Miranda, Sociedades Anonimas, Rio de Janeiro, Mundo Medico Borsoi \& C., 08/11/1937, pp. 328-35.

VALVERDE, Trajano de Miranda, Sociedades por ações (comentários ao Decreto-Lei n. 2.627, de 26 de setembro de 1940), Vol. 2, Rio de Janeiro, Revista Forense, 1941.

VALVERDE, Trajano de Miranda, Sociedades por ações, $2^{\mathrm{a}}$ ed., Rio de Janeiro, Forense, 1953.

VAMPARYS, Xavier, Validité et eficacité des clauses d'entraînement et de sortie cojointe dans les pactes d'acionnaires, in Bulletin Joly Sociétés, julho, 2005, pp.821-838.

VAMPRÉ, Spencer, Das sociedades anonymas, São Paulo, Pocai-Weiss \& Cia, 1914.

VAMPRÉ, Spencer, Tratado elementar de direito comercial, Rio de Janeiro, Briguiet, 2 vol., 1922.

VEIGA JÚNIOR, Dídimo Agapito da, As sociedades anônimas, Rio de Janeiro, Imprensa Nacional, 1888.

VENTURA, Raúl, Acordos de voto: algumas questões depois do Código das

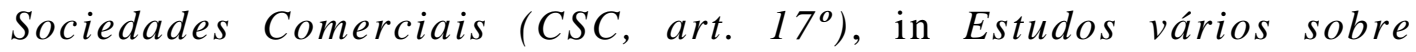
sociedades anônimas: comentários ao Código das Sociedades Comerciais, Coimbra, Almedina, 1992, pp. 7-101. 
VENTURA, Raúl, Estudos vários sobre sociedades anónimas - comentário ao código das sociedades comerciais, Coimbra, Almedina, 1992.

VERRUCOLI, Piero e PIRAS, Antonio, Evolution et perspectives du droit des sociétés à la lumiére des differentes expériences nationales, Milano, Giuffré, 1968.

VIANDIER, Alain, La notion d'associé, Paris, Librairie Generale de Droit et de Jurisprudence, 1978.

VILlELA, João Baptista, Por uma nova teoria dos contratos, in Separata da Revista de Direito e de Estudos Sociais, Coimbra, Ano XX, AbrilDezembro, 1975, pp.313-338.

VON ADAMEK, Marcelo Vieira, Abuso de minoria em direito societário (abuso das posições subjetivas minoritárias). Tese de Doutorado em Direito Comercial, Faculdade de Direito da Universidade de São Paulo, 2010.

VON ADAMEK, Marcelo Vieira, Apontamentos à exclusão de sócios por falta grave no Código Civil, in AA.VV., Temas de Direito Societário e Empresarial Contemporâneos - Liber Amicorum Prof. Dr. Erasmo Valladão Azevedo e Novaes França, São Paulo, Malheiros, 2011, pp. 185-215.

VON GIERKE, Otto, Sulla storia del principio di maggioranza, in Rivista delle Società, 1958, pp. 1103-1120.

WALD, Arnoldo, A contratualização do direito societário, in Revista de Direito Bancário e de Mercado de Capitais n. ${ }^{\circ}$ 26, outubro - dezembro, 2004, pp. 21-5 [= RF, n. ${ }^{\circ} 380$, julho-agosto, 2005, pp. 463-6].

WALD, Arnoldo, Do cabimento da denúncia vazia de acordo de acionistas firmado por prazo indeterminado, especialmente nos casos de inadimplemento e de má-fé da outra parte ou de conflito de interesses superveniente (Parecer), in RDCv n. ${ }^{\circ} 78$, 1996, pp. 151-75.

WALD, Arnoldo, Da transferência de ações ordinárias detidas pelo Estado de Minas Gerais no capital votante da CEMIG - Inalterabilidade da escritura de controle acionário com a realização da operação $e$ celebração de acordo de acionistas, no moldes propostos (Parecer), in Cadernos de direito tributário e finanças públicas n. ${ }^{\circ} 22,1998$, pp. 279-96.

WEBER, Christoph, Privatautonomie und Außeneinfluß im Gesellschaftsrecht, Tübingen, Mohr Siebeck, 2000.

WIEDEMANN, Herbert, Gesellschaftsrecht I - Grundlagen München, Beck, 1980. 
WIEDEMANN, Herbert, Vínculos de lealdade e regra de substancialidade in AAVV. Temas de Direito Societário e Empresarial Contemporâneos.Liber Amicorum Prof. Dr. Erasmo Valladão Azevedo e Novaes França, Malheiros, São Paulo, 2011, pp. 147-168

WIEDEMANN, Herbert, Die Zukunft des Gesellschaftsrechts, in Festschrift für Robert Fischer, Walter de Gruyter, Berlin, 1979, p. 883-903.

XAVIER, Vasco da Gama Lobo, A validade dos sindicatos de votos no direito português constituído e constituendo, in Revista da Ordem dos Advogados Portugueses, dezembro, 1985, pp. 639-653. 
ANÁlises JURISPRUdenCIAIS

\begin{tabular}{|c|c|c|}
\hline \multicolumn{3}{|c|}{ TJSP - PorCentaGeM DE TEMAS } \\
\hline & Número de Decisões & Porcentagem \\
\hline Decisões analisadas & 231 & $100 \%$ \\
\hline Questões Processuais & 181 & $78,35 \%$ \\
\hline $\begin{array}{c}\text { Conformidade com a lei } \\
\text { de S.A. e Voto }\end{array}$ & 44 & $19,05 \%$ \\
\hline Interpretação & 6 & $2,6 \%$ \\
\hline
\end{tabular}

\begin{tabular}{|c|c|}
\hline \multicolumn{2}{|r|}{ TJ - SP } \\
\hline \multicolumn{2}{|r|}{ ACÓRDÃo N. ${ }^{\circ} 1$} \\
\hline Data do julgamento & $17 / 10 / 2002$ \\
\hline n. ${ }^{\circ}$ do acórdão & AI. $n^{\circ} 250.715 .4 / 7$ \\
\hline Relator & Silveira Netto \\
\hline Comentários & $\begin{array}{l}\text { O acórdão entende o acordo de acionistas como } \\
\text { apto a manter equilíbrio entre os sócios e } \\
\text { sociedade. A decisão de tornar sem efeito as } \\
\text { deliberações de determinadas assembléias } \\
\text { fundamentou-se, portanto, no que havia sido } \\
\text { decidido anteriormente entre as partes, no } \\
\text { acordo }\end{array}$ \\
\hline \multicolumn{2}{|r|}{ ACÓRD̃̃o N.² } \\
\hline Data do julgamento & $10 / 12 / 2002$ \\
\hline n. ${ }^{\circ}$ do acórdão & Apel. $n^{\circ} 126.712 .4 / 3$ \\
\hline Relator & Ruiter Oliva \\
\hline Comentários & $\begin{array}{l}\text { O julgado entende que o acordo de acionistas } \\
\text { somente se insere no âmbito societário se versar } \\
\text { sobre as matérias previstas no art. } 118 \text { da Lei de } \\
\text { S.A. (compra e venda de ações ou direito de } \\
\text { voto que estejam arquivados na sede). Caso } \\
\text { contrário, é disciplinado pelo Código Civil, e } \\
\text { não pelo direito societário. }\end{array}$ \\
\hline \multicolumn{2}{|r|}{ ACÓRDÃO N.º 3} \\
\hline Data do julgamento & $11 / 11 / 2007$ \\
\hline n. ${ }^{\circ}$ do acórdão & AI 529.384.4/3-00 \\
\hline Relator & Boris Kauffmann \\
\hline Comentários & $\begin{array}{l}\text { O Acórdão interpreta o acordo de acionistas que } \\
\text { trata de quorum exigido para reunião do } \\
\text { Conselho de Administração de maneira a não } \\
\text { inviabilizar a existência da companhia }\end{array}$ \\
\hline \multicolumn{2}{|r|}{ ACÓRDÃO N.4 } \\
\hline Data do julgamento & $09 / 11 / 2010$ \\
\hline n. ${ }^{\circ}$ do acórdão & AI. $n^{\circ} 990.10 .280 .968-4$ \\
\hline Relator & Grava Brazil \\
\hline Comentários & $\begin{array}{l}\text { O Agravo de Instrumento trata caso de } \\
\text { antecipação de tutela, por isso o exame não é }\end{array}$ \\
\hline
\end{tabular}




\begin{tabular}{|c|c|}
\hline & $\begin{array}{l}\text { aprofundado. No entanto, nota-se no acórdão a } \\
\text { consideração da quebra do affectio societatis e a } \\
\text { redução dos honorários do sócio-administrador } \\
\text { para um patamar muito menor do que o } \\
\text { convencionado anteriormente, tentando } \\
\text { preservar a integridade da Sociedade. }\end{array}$ \\
\hline \multicolumn{2}{|r|}{ ACÓRDÃO N. ${ }^{\circ} 5$} \\
\hline Data do julgamento & $18 / 11 / 2008$ \\
\hline n. ${ }^{\circ}$ do acórdão & Apel. $n^{\circ} 597.279-4 / 7-00$ \\
\hline Relator & Grava Brazil \\
\hline Comentários & $\begin{array}{l}\text { Entendeu-se que devido à quebra da affectio } \\
\text { societatis, a administração conjunta pela } \\
\text { totalidade dos sócios prevista no contrato social } \\
\text { se tornou inviável. Assim, permitiu-se que a } \\
\text { administração da sociedade se realizasse por } \\
\text { dois dos sócios até o fim da lide. Logo, o } \\
\text { acórdão coloca a preservação da sociedade à } \\
\text { frente tanto do contrato social, como acordo de } \\
\text { acionistas. }\end{array}$ \\
\hline \multicolumn{2}{|r|}{ ACóRDÃO N. ${ }^{\circ} 6$} \\
\hline Data do julgamento & $16 / 09 / 2009$ \\
\hline n. ${ }^{\circ}$ do acórdão & Apel. n. ${ }^{\circ} 628.733 .4 / 9-00$ \\
\hline Relator & A. C. Mathias Couto \\
\hline Comentários & $\begin{array}{l}\text { Em acordo de acionistas contendo cláusula que } \\
\text { proíbe pessoas estranhas à companhia de } \\
\text { ingressarem em sua sede, o Relator entende tal } \\
\text { estipulação como lícita, uma vez que analisa o } \\
\text { acordo como um simples contrato. }\end{array}$ \\
\hline
\end{tabular}

\begin{tabular}{|c|l|}
\hline \multicolumn{2}{|c|}{ STJ } \\
\hline Data do julgamento & $13 / 08 / 2002$ \\
\hline n. $^{0}$ do acórdão & Medida Cautelar. no 4.220 \\
\hline Relator & Ari Pargendler \\
\hline & Ao interpretar acordo de acionistas cujo objeto a \\
cisão parcial da companhia e uma cláusula \\
acessória de "administração transitória", a \\
Relatora comenta que normas societárias e \\
acordos parassocias se distinguem pela causa \\
eficiente, e que estes são acordos paralelos e \\
dependentes do estatuto, e representam a \\
"declaração e a obrigação pessoal do sócio como \\
titular de seu patrimônio". Com esse \\
fundamento, o Acordo de Acionistas deve \\
prevalecer.
\end{tabular}

\section{Caso Petroplástic}

Abaixo, tem-se a análise de caso bastante citado ao longo da tese, envolvendo a empresa Petroplastic (Recurso Especial n. ${ }^{\circ}$ 388.423-RS). 
A Primera Indústria e Comércio Ltda. ajuizou Ação Ordinária contra Petroplastic Indústria de Artefatos Plásticos Ltda. e Petrobrás Química S.A. - Petroquisa para resolver o acordo de acionistas, argumentando, em síntese que, por ter se rompido a affectio societatis, com a exclusão de uma das partes do acordo, não poderia este prosseguir. A sentença, proferida pela Juíza de Direito Rejane Maria Dias de Castro Bins, julgou procedente o pedido tendo por resolvido o acordo de acionistas. Ou seja, entendeu que a quebra da affectio societatis seria suficiente para extinguir o acordo de acionistas.

Em segunda instância, o Desembargador Armínio José Abreu Lima da Rosa, negou provimento à Apelação de Petroplastic por entender que ela descumpriu o acordo de acionistas, uma vez que passou a agir, abertamente, contra a cooperação e interesses comuns.

Importante destacar, que o acórdão entendeu que a quebra da affectio societatis, por conduta "rematadamente emergente" de um dos partícipes não significaria outra coisa senão inequívoco inadimplemento da mais básica, mais óbvia e mais relevante obrigação contratual. O acórdão também ressaltou que, quando se fala em affectio societatis, não se trata do crasso erro de equiparar, sempre, contrato plurilateral com sociedade, o que se deseja exprimir, e o foi, com todas as letras, corresponde ao grave incumprimento contratual por parte da Petroplastic que levou "ao óbito da possibilidade de vida em comum. Sabe-se que o dever básico, aqui, corresponde, inequivocamente, à contribuição comum, à 'socialização' a que alude Pontes de Miranda (in "Tratado de Direito Privado", 38/9, par. 4.185, 7), a quebra da proclamada affectio societatis outra coisa não traduz, ao fim e ao cabo, senão rematada inadimplência a básico dever".

O STJ ao analisar a questão destaca a ausência de confiança e quebra do dever de cooperação e lealdade entre as partes do acordo de acionistas de que se cuida. Assim, apóia a solução dada em primeira e segunda instância, a resolução do acordo de acionistas.

Logo, tanto o STJ, quanto as instâncias ordinárias concluíram que a resolução do acordo de acionistas foi medida de rigor. Para tanto, utilizam como fundamento a quebra da affectio societatis, com alicerce na deslealdade e no conjunto de atitudes incompatíveis com o dever de cooperação, inclusive a vedação do acesso do representante da empresa Primeira Indústria e Comércio Ltda. às dependências da Companhia. 


\section{REFERÊNCIAS JURISPRUDENCIAIS}

PANORAMA GERAL DOS RESULTADOS

\begin{tabular}{|l|l|}
\hline Instância judicial: & Tribunal de Justiça do Estado de São Paulo \\
\hline $\begin{array}{l}\text { Data de levantamento } \\
\text { (checagem): }\end{array}$ & 13.3 .11 \\
\hline Campo de pesquisa: & Inteiro teor (= "Pesquisa livre") \\
\hline
\end{tabular}

\begin{tabular}{|c|l|c|}
\hline $\begin{array}{c}\text { Argumento de } \\
\text { pesquisa: }\end{array}$ & Espécie de decisão: & Número de resultados: \\
\hline \multirow{2}{*}{$\begin{array}{c}\text { A) “Acordo de } \\
\text { acionistas" }\end{array}$} & $\begin{array}{c}\text { a) Acórdãos } \\
\text { b) Decisões } \\
\text { Monocráticas }\end{array}$ & 190 \\
\hline \multirow{2}{*}{$\begin{array}{c}\text { B) "Acordo de } \\
\text { quotistas" }\end{array}$} & $\begin{array}{l}\text { a) Acórdãos } \\
\text { b) Decisões } \\
\text { Monocráticas }\end{array}$ \\
\hline \multirow{2}{*}{ C) "Pacto parassocial” } & a) Acórdãos & 31 \\
\hline & $\begin{array}{l}\text { b) Decisões } \\
\text { Monocráticas }\end{array}$ \\
\hline
\end{tabular}

Total de Resultados: 231 decisões

Devido ao número elevado, optou-se por não citar todos os acórdãos consultados: na seção ANÁLISES JURISPRUDENCIAIS apresentou-se a porcentagem dos temas, e uma análise dos principais acórdãos.

\begin{tabular}{|l|l|}
\hline Instância judicial: & Superior Tribunal de Justiça \\
\hline $\begin{array}{l}\text { Data de levantamento } \\
\text { (checagem): }\end{array}$ & 13.3 .11 \\
\hline Campo de pesquisa: & Inteiro teor (= "Pesquisa livre") \\
\hline
\end{tabular}

\begin{tabular}{|c|c|c|}
\hline $\begin{array}{l}\text { Argumento de } \\
\text { pesquisa: }\end{array}$ & Espécie de decisão: & Número de resultados: \\
\hline \multirow{2}{*}{$\begin{array}{l}\text { A) "Acordo de } \\
\text { acionistas" }\end{array}$} & a) Acórdãos & 18 \\
\hline & b) Decisões Monocráticas & 121 \\
\hline \multirow{2}{*}{$\begin{array}{l}\text { B) "Acordo de } \\
\text { quotistas" }\end{array}$} & a) Acórdãos & 0 \\
\hline & b) Decisões Monocráticas & 3 \\
\hline \multirow{2}{*}{$\begin{array}{l}\text { C) "Pacto } \\
\text { parassocial" }\end{array}$} & a) Acórdãos & 0 \\
\hline & b) Decisões Monocráticas & 0 \\
\hline
\end{tabular}

Total de Resultados: 139 decisões 


\section{ACórdãos Consultados}

\author{
1 - RESP N. ${ }^{\circ} 1.102 .424$ - SP \\ RELATOR(A): MINISTRO MASSAMI \\ UYEDA \\ DATA DO JULGAMENTO: 18/08/2009 \\ 2 - REsp n. ${ }^{\circ} 856.826$ - DF \\ Relator(a): Ministra Nancy Andrighi \\ Data do julgamento: 19/02/2008 \\ 3 - MC n. ${ }^{\circ} 13.304$ - PR \\ Relator(a): Ministra Eliana Calmon \\ Data do julgamento: 25/09/2007 \\ 4 - REsp n. ${ }^{\circ} 784.267$ - RJ \\ Relator(a): Ministra Nancy Andrighi \\ Data do julgamento: 21/08/2007 \\ 5 - Edcl no Resp n. ${ }^{\circ} 388.423$ - RS \\ Relator(a): Ministro Jorge \\ Scartezzini \\ Data do julgamento: 07/12/2006 \\ 6 - RO em MS no 18.769 - PR \\ Relator(a): Ministra Eliana Calmon \\ Data do julgamento: 02/12/2004 \\ 7 - AgRg na MC n. ${ }^{\circ} 8.527$ - PR \\ Relator(a): Ministra Eliana Calmon \\ Data do julgamento: 17/08/2004 \\ 8 - AgRg no AI n. ${ }^{\circ} 481.023$ - MG \\ Relator(a): Ministro Fernando \\ Gonçalves \\ Data do julgamento: 18/12/2003 \\ 9 - REsp n. ${ }^{\circ} 413.722-\mathrm{RS}$ \\ Relator(a): Ministro Sálvio de \\ Figueiredo Teixeira \\ Data do julgamento: 13/05/2003
}

10 - REsp n. ${ }^{\circ} 388.423$ - RS

Relator(a): Ministro Sálvio de

Figueiredo Teixeira

Data do julgamento: 13/05/2003

11 - AgRg no AgRg na MC n. ${ }^{\circ} 4.220$ $-\mathrm{RJ}$

Relator(a): Ministra Nancy Andrighi

Data do julgamento: 11/11/2002

12 - $\mathrm{MC} \mathrm{n} .^{\circ} 4.220-\mathrm{RJ}$

Relator(a): Ministra Nancy Andrighi

Data do julgamento: 13/08/2002

13 - MC 2.035/MG

Relator(a): Ministro Cesar Asfor Rocha

Data do julgamento: 21/10/1999

14 - RO em MS 10.120/RS

Relator(a): Ministro José Delgado

Data do julgamento: 29/04/1999

15 - AgRg no AI n. ${ }^{\circ} 142.333$

Relator(a): Ministro Carlos Alberto Menezes Direito

Data do julgamento: 26/06/1997

16 - REsp n. ${ }^{\circ} 43.457-2$

Relator(a): Ministro Eduardo Ribeiro

Data do julgamento: 30/10/1995

17 - Edcl no REsp n. ${ }^{\circ}$ 27.517-2

Relator(a): Ministro Eduardo Ribeiro

Data do julgamento: 15/06/1993

18 - REsp n. ${ }^{\circ} 27.517$

Relator(a): Ministro Eduardo Ribeiro

Data do julgamento: 23/03/1993

As decisões monocráticas do STJ não foram individualmente citadas, tratando basicamente de discussão de competência interna do STJ e do cabimento dos recursos diante das sumulas 5 e 7 (impossibilidade de interpretação de cláusula contratual e fatos pelo STJ). 


\begin{tabular}{|l|l|}
\hline Instância judicial: & Supremo Tribunal Federal \\
\hline $\begin{array}{l}\text { Data de levantamento } \\
\text { (checagem): }\end{array}$ & 13.3 .11 \\
\hline Campo de pesquisa: & Inteiro teor (= "Pesquisa livre") \\
\hline
\end{tabular}

\begin{tabular}{|c|l|c|}
\hline $\begin{array}{c}\text { Argumento de } \\
\text { pesquisa: }\end{array}$ & \multicolumn{1}{|c|}{ Espécie de decisão: } & Número de resultados: \\
\hline \multirow{2}{*}{$\begin{array}{c}\text { A) “Acordo de } \\
\text { acionistas" }\end{array}$} & $\begin{array}{l}\text { a) Acórdãos } \\
\text { b) Decisões } \\
\text { Monocráticas }\end{array}$ & 7 \\
\hline \multirow{2}{*}{$\begin{array}{c}\text { B) "Acordo de } \\
\text { quotistas" }\end{array}$} & $\begin{array}{l}\text { a) Acórdãos } \\
\text { b) Decisões } \\
\text { Mocráticas }\end{array}$ \\
\hline \multirow{2}{*}{ C) "Pacto parassocial" } & a) Acórdãos & 0 \\
\hline & $\begin{array}{l}\text { b) Decisões } \\
\text { Monocráticas }\end{array}$ \\
\hline
\end{tabular}

Total de Resultados: 8 decisões

\section{ACórdãos Consultados}

1 - ADI $1846 \mathrm{MC} / \mathrm{SC}$

Relator(a): Ministro Carlos Velloso

Data do julgamento: $25 / 06 / 1998$

Decisões monocráticas do STF foram consultadas mas não citadas, uma vez que, por suas próprias características, não tratam o tema dos acordos de acionistas, mas, basicamente de (i) análise da legislação que proíbe o Poder Executivo, às empresas públicas e de economia mista cujo controle acionário pertença ao Estado e (ii) descabimento da via recursal. 